\title{
UC-NRLF
}

||||||||||||||||||||||||||||||||||||

B $4 \quad 314971$ 


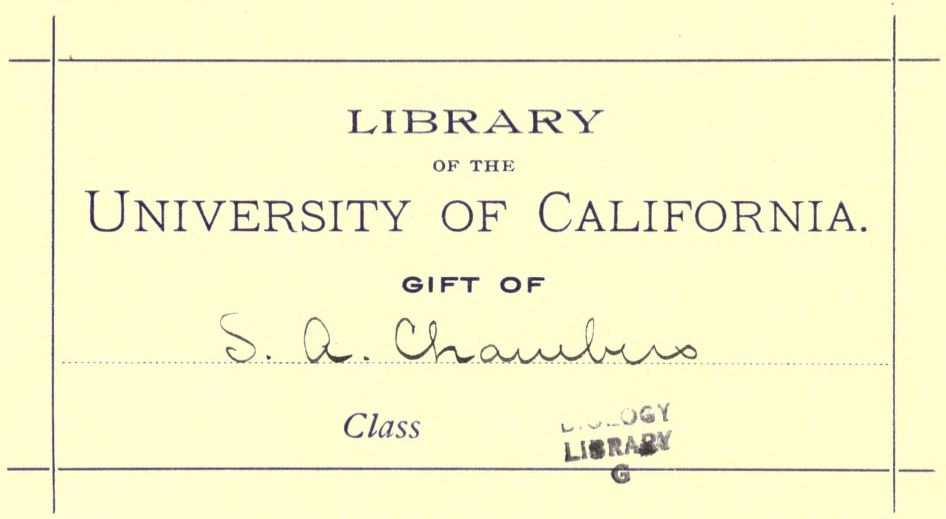


120

Sarnual N. Ohambers. 
$x^{2}+x^{2}=$ 


\section{A POPULAR}

\section{CALIFORNIA FLORA, \\ OR,}

\section{MANUAL OF BOTANY FOR BEGINNERS.}

CONTAINING

DESCRIPTIONS OF FLOWERING PLANTS GROTING IN CENTRAL CALIFORNIA, AND WESTWARD TO THE OCEAN.

\section{WITI!}

ILLUSTRATED INTRODUCTORY LESSONS, ESPECIALLY ADAPTED TO THE PACIFIC COAST.

\section{Sitth hiruised Edition.}

SAN FRANCISCO:

A. L. BANCROFT AND COMPANY.

1885 . 


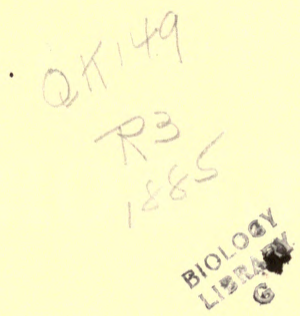

Entered according to Act of Congress, in the year 1882, Br A. L. BANCROFT AND COMPANY, In the office of the Librarian of Congress, at Washington. 


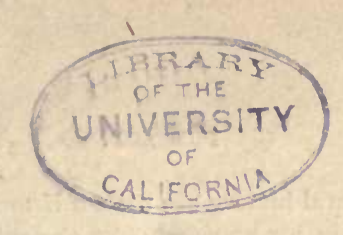

\section{PREFACE.}

ThE first edition of this book was prepared for the press during the evenings and Saturdays of the month of January, 1879. The hope that an abler hand would undertake the task deferred the beginning, and the needs of a class of over five hundred pupils hastened the completion of a work that.would have been more slowly elaborated had the reputation of the author been the only consideration. The errors incident to such rapid work were as far as possible corrected the following year, in a second edition, which was prefaced as follows:

"I have endeavored to prepare an inexpensive manual which will enable beginners in botany to determine the names of all plants with conspicuous flowers that may be found growing wild in the Central Valley of California from Visalia to Marysville, and through the Coast Ranges from Monterey to Ukiah. Over six hundred species of plants are characterized by descriptions condensed, for the most part, from Vol. I of the "California Botany,' and Sereno Watson's 'Revision of the North American Liliaccæ.' Valuable material has also been obtained from a 'Revision of the Eriogoneæ,' by Torrey \& Gray, Gray's 'Synoptical Flora of North America,' and 'Gray's Manual of Botany.'

"Plants belonging to the Parsnip, Aster, Willow, Oak, and Pine Families, are not described, being mostly too difficult for beginners, or of little interest to them. The Introductory Lessons are designed to show the learner how to study the growth of plants, as well as to give such knowledge of their structure as will enable him to understand the descriptions in the Flora. The 'Glossary of Generic and Specific Names' will enable the student to make appropriate common names for most plants.

"To the authors whose works have furnished the materials for this book is due the credit for whatever of excellence it may possess; to the compiler, who may, in a fcw cases, have misrepresented these authors, attaches the blame for most of its defects.

"I am indebted for suggestions and criticisms to Prof. E. W. Hilgard, Dr. C. L. Anderson, Prof. W. H. Brewer and Dr. Asa Gray. To the latter I am especially grateful for his kind interest in my humble work."

One third of the second edition was new matter, and only about half of the book in its present form is printed from the stereotype plates of the first edition. The newer half of the work, although necessarily partaking somewhat of the nature of patchwork, is as good as I can make it. My drawings upon wood have been faithfully engraved, and, though claiming no artistic merit, will, I trust, prove helpful to the learner. With few exceptions-always noted in the text-the plants, or parts of plants, are represented of the natural size. Besides the more obvious improvements, an entirely new Analytica] Key replaces the old one; and our most common oaks are described. 
Assuming that facts in natural history are useless if merely memorized from the book, and that the student must earn his knowledge by observing and experimenting, it is obviously best to encourage lim at first by showing him how to try simple experiments whose results are easily interpreted. Seeds are the best material for such experiments, since the plenomena connected with their germination are not only easily observed, but deeply interesting. For this reason what may seem a disproportionate space in the Introductory Lessons is devoted to "The Beginnings of Plant Life." There are no lessons of greater educational value than those given to observing eyes by the growth of a plant from the first quickening of the dry embryo to the putting forth of flowers and the ripen. ing of fruit. A sunny window in each school-room should be devoted to these beautiful object lessons of nature. It must not be forgotten, however, that since most young people are eager to learn the names of plants whose flowers they admire, it is best to devote most of the spring months to the study of Systematic Botany. The child's "What is it?" and the finger pointing to the plant in bloom, show plainly with what to begin the study of botany. Baron Frederick von Mueller says in his preface to an elementary work upon the botany of Victoria, Australia: "An experience of nearly forty years has convinced the author that the use of a grammar-like publication for initiating into a study of plants is alike wearisome to teacher and children, and that as a rule, subject to rare exceptions, the knowledge acquired from the ordinary first elementary works on botany is as quickly lost as gained. The only method of rendering such studies agreeable and lastingly fruitful consists in arousing an interest of the young scholars in the native plants of their locality, to afford them all possible facilities to recognize and discriminate all the various plants within reach, to lead them by observations thus started to comprehend the limits of specific forms, of generic and ordinal groups, and to conduct them afterwards to the more difficult study of special anatomy and physiology of plants."

Teachers and learners are here reminded of the importance of carefully writing out the details of experiments tried, as well as descriptions of what has been observed. In the words of Dr. Asa Gray: "The naturalist must not only observe that he may describe, but describe if he would observe."

It will be noticed-and the fact has formed the basis of a criticism-that the descrip. tions of genera and species in this Flora are very brief; as a rule only the contrasting characteristics being given, since more is calculated to confuse rather than help the beginner. Dr. Gray says: "In floras, as in more general works, abridged descriptions or diagnoses suffice-indeed, are preferable in all cases where the region is pretty well explored, and where materials can be thoroughly elaborated."

Although the Flora is designed especially for students in Central California, it will be found only a little less useful to those studying as far south as Los Angeles, or as far north as the Columbia. The Introductory Lessons are suited to the entire Pacific Coast. San Francisco, January, 1882. 


\section{INTRODUCTORY LESSONS}

IN

\section{STRUCTURAL BOTANY.}

\section{SECTION 1.-THE BEGINNINGS OF PLANT LIFE.}

1. If the first rain of the wet season is followed by warm, sunny weather, specks of green will soon appear among the dry stems of last year's weeds; and in fence corners or other eddy nooks where summer winds have drifted seeds and covered them with dust, you may find perfect mats of baby plants. With a shovel skim off a few square inches of this plant-bearing soil, and carefully examine it. Except a few green needles, which you recognize as spears of grass, most of these little plants seem to consist of white stems, which split at the top into pairs of green leaves. Looking sharply, you may find between each pair of leaves a

1. Seed of Bur-clover just before it appears above ground. 2. Same three days older. 3. Mustard. 4. Bur clover showing the first and second plumule leaves; the former simple (apparently), the latter with three leaflets. 5 . Mallows (Malva borealis), showing the long-petioled seed leaves (Cotyledons, and one plumule leaf unfolded. 6. F1larla (Erodium), with lobed or sub-compound seed leaves.
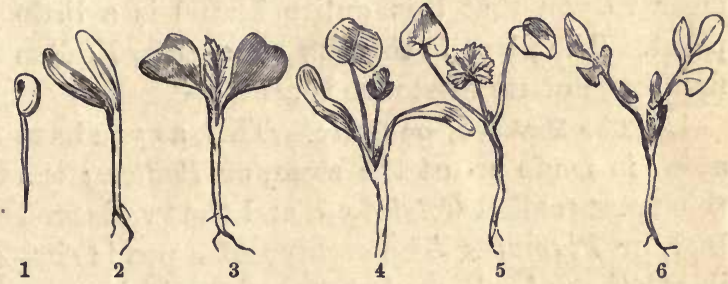

tiny bud; or, in the older plants, this may have grown other leaves, which curiously enough are not like the first two. (Figures 1 to 6). Searching through the shovelful of earth you will likely find plants in all stages of growth, from swollen and sprouting seeds to stems, which are just pushing their bowed leaf-heads into the sunlight. Here, then, is material from which you may learn how plants grow; a lesson, remember, which no text-book or schoolmaster can teach you. It will be easier, however, since most of these early wild plants come from very small seeds, to take 
your first lessons from plants which have larger beginnings. You should first study-

2. The Plant in the seed. Get many kinds of large seeds, such as peas, beans, squash-seeds, buckeyes, castor beans, corn, etc. Put them in water that they may become soft enough to be readily separated into their parts. In a day or two starchy seeds, such as peas or beans, will be in good condition.

3. First take a bean and make drawings showing the outlines as seen sidewise and edgewise. Any marks that seem to be found on all beans must be put down in the drawing, but do not bother about the shading. These attempts to represent what you see will lead to the discovery of certain marks on the concave edge of the bean, the meaning of which you may sometime learn by studying the growth of the seed in the pod. After you have thus studied the outside of the seed, slit it along the back with a sharp knife and take out the kernel. It readily splits into halves which are held together near one end by a short stem. Upon breaking them apart the stem sticks to one half, and you discover growing from the inner end a pair of tiny embracing-leaves. Make ancther drawing and compare it with Fig. 7. Presently it will be clear to you that this entire kernel is a littlo plant. The plant in this dry apparently lifeless first stage of its existence is called-

4. The Embryo, or Germ. This, as you have seen, is made up of the stem, or Radicle; the thick parts called Cotyledons, and the two-leaved bud, or Plumule. The embryo of a pea is similar to that of a bean, but the plumule is more decidedly a bud. Fig. 8 represents the straight and plumule; $b$, outer side of the embryo of a peanut. The radicle is not bent around against the cotyledons as in the pea and bean, and the plumule shows two divided leaflets. The cotyledons of the squash are thin and the plumule is scarcely visible. Lupine, though its seeds resemble beans, has a long radicle and a minute plumule. The buckeye seems to have a long radicle, but since it splits nearly to its point, where you will find a large plumule, it is evident that the apparent radicle is mostly made up of the cotyledon stems (petioles). 
5. Albuminous seeds. Remore the shell-like coat of a castor bean, and carefully split it flatwise. What at first seems to be a large plumule proves to be free from the rest of the kernel, and with care you may be

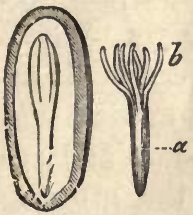

9

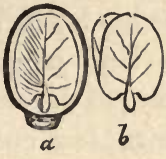

10

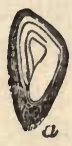

11

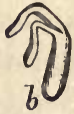

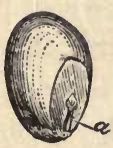

12

9. Seed of Willow or Dig. ger Pine cut so as to show the straight embryo in the center of the oily albumen. $a$ and $b$, embryo taken out, the cotyledons $(b)$ separated. 10. Seed of the Castor-beau. $a$, the broad thin embryo nearly dividing the albumen; $b$, the embryo removed and the leaf-like cotyledons separated. 11. Seed of Datura (Brugmangia), showing at $a$ the bent embryo in the scanty al bumen; $b$, the embryo taken out and the slender cotyledons separated. 12. A grain of coffee. $a$, the straight embryo.

able to get it out whole (Fig. 10.) It is a straight embryo with beautifully veined, leaf-like cotyledons, embedded in a white, oily substance, which makes up the mass of the kernel. This substance is called Albumen, a name which applies to anything inclosed with the embryo by the seed coats. Peas, beans, acorns, nuts, and most large seeds have no albumen. Carefully cut thin slices from a well soaked coffee grain until its embryo appears as represented in Fig. 12. The horny, folded albumen makes up most of the seed. A similar, but smaller embryo, may be found in the brain-shaped, fleshy albumen of the ivy seed. The embryo of the Tree-Datura, or Stramonium, is shown in Fig. 11. It has slender cotyledons, folded down against a thick radicle, the whole embedded in tough, fleshy albumen. Take the embryo of a Morning-Glory seed aud pick the bits of transparent, jelly-like albumen out of the pockets in the crumpled cotyledons. An attempt to flatten out the cotyledons will probably result in something like $b$, Fig. 13, which may lead you to suppose that the cotyledons are separately crumpled, which is not the case. They stick closely together by their inner faces, as do the cotyledons of other seeds you have examined, and they are crumpled as one; but, being notched at the end, they readily split down the

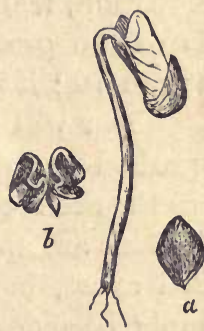

13. Morning - Glory fust appearing above the ground with the seed coat sticking to the cotyledons. $a$, the swollen seed; $b$, embryo, with the crumpled cotyle. dons split down the middle in the attempt to flatten them. center. Buckwheat seeds will give you some trouble. Indeed, it will 
be much easier to make out the exact shapes and positions of the embryos in most albuminous seeds after they have begun to grow.

Monocotyledonous Embryos. Corn, wheat, oats, and possibly a few other seeds in your collection, are different in plan from any yet described. In corn the soft portion called the chit is the embryo. Wheat and oats have smaller but similar embryos. You cannot easily distinguish the parts of these embryos, but you can, at least, determine that they have not two cotyledons. Really they have one cotyledon, and are therefore said to be Monocotyledonous. When you study the growing seeds you will see how widely they differ from seeds which have-

Dicotyledonous Embryos. These are embryos, which, like the bean, have two cotyledons. A few plants belonging to the Pine Family have

Polycotyledonous Embryos. Fig. 12 shows the embryo of the common Willow or Digger Pine, which has more than two cotyledons in a whorl at the top of the radicle.

The Germination of Seeds. Plant the remainder of your seedsthose of a kind together-in boxes or pots of sand, or any kind of loose soil you can get. Keep this little experimental garden in a warm place, where it can get a bit of sunshine, and water it daily. At intervals of three or four days dig up one of each kind of seed, and, after careful examination, make drawings to illustrate the successive stages of growth. It is of the greatest importance that you repeatedly attempt to draw what you see; it is of the least importance that your drawings are pretty.

You will learn, among many interesting facts, that most seeds are pushed up to the surface of the ground by the growth of the radicle. There the seed-coats drop off (except that in seeds without albumen the cotyledons are apt to slip out of their coats on the way up); the cotyledons spread apart, become longer and broader, and turn green; lastly, the plumule becomes a leafy stem. Meanwhile, roots grow from the lower end of the radicle. Some cotyledons, like those of the pea, do not appear above ground, but send the plumule up. The seeds of Big-roota pest which grows in nearly every field-behave in a remarkable manner. The nut-like seeds drop from their prickly pods in June or July, and soon become covered with leaves. The rains of November and December cause them to sprout, as represented at $d$. The mimic radicle-really a 
tube formed by the united petioles, or stems, of the thick cotyledons, and only tipped by the radiclepenetrates the ground to a depth, usually, of four or five inches. The plumule meanwhile, as shown in $f$, remains dormant in the bottom of the tubular sprout. When the petiole growth ceases, the radicle grows rapidly by aldsorbing the nourishment stored in the cotyledons, and becomes a tuber. Meanwhile the plumule begins its upward growth, splitting the petioles apart, and usually escaping from between them, as shown in the figure below $c$. In this wonderful way the plumule bud is deeply planted together with nourishment (stored in the radicle) which, if necessary, can be used to aid its

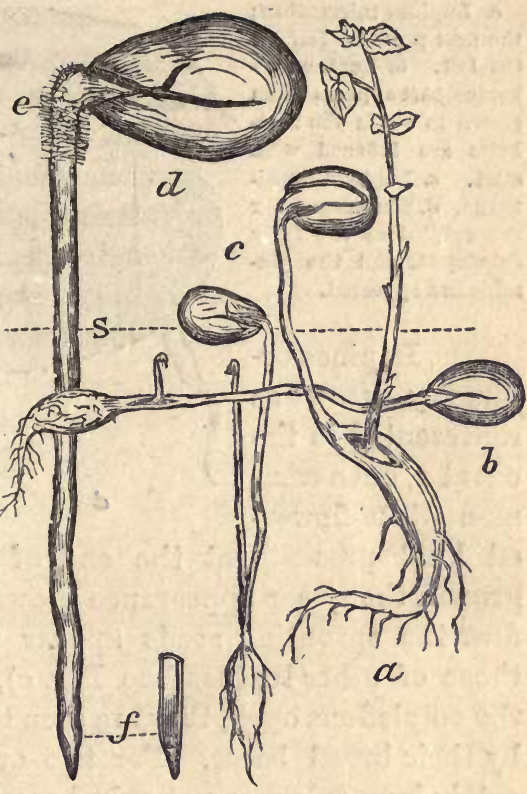
first growth. The reason for this curious behavior is obvious, when we know that ground squirrels are fond of these seeds, and that a severe frost will kill the young plant. If the seeds wait till warm weather to sprout, hungry rodents may find them; if they germinate early, and in the manner of other seeds, Jack Frost may nip them.*

* Dr. Asa Gray, who first experimented with these seeds, found them to grow as represented at $a$, in the figure [reduced one fourth from Fig. 43, Botanical Text-book, edition of 1879]. Evidently on accout of some obstruction, probably the bottom of a small pot, the seeds were elevated two or three inches above the surface of the soil [the aotted line $\mathbf{S}$ represents the surface of the ground for flgures $a, b$, and $c]$. My experiments with seeds planted in shallow boxes gave very different results-shown at $b$, which is a reduced copy of Fig. 14 of second edition. The plants came up about four inches from where the seeds were planted, the plumule being pushed laterally that distance by the elongation of the cotyledon petioles. Such inexplicable behavior stimulated to further observation, which resulted in the discovery that naturally planted seeds, unhampered by boxes or pots, usually grow as represented at $c$ and $d$. In one instance a sprout measure $d$ seven inches from the plumule to the cotyledons! The hairs at $e$ probably help the sprout to penetrate the soll, by fastening on to the surface crust. Curiously enough, growing sprouts underground frequently avold obstacles without touching them. 
a. Lupinus micranthus; the first piumule leaf on the left. $b$. Lupinus arboreus, as it appears when grown in sand; the roothairs are ladened with sand. c. Lupinus densiflorus. $d$. The same, after the cotyledons are fully developed, and the plumule has appeared.

\section{Lupines or-} dinarily grow as represented in the cut at $a$, but a common white-flower-
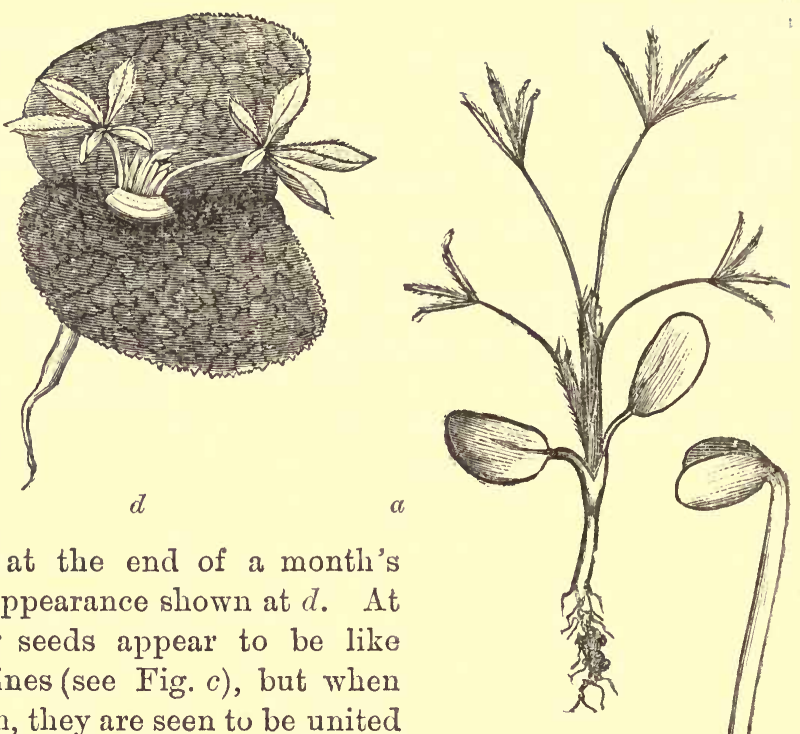
ed kind presents at the end of a month's growth the queer appearance shown at $d$. At first the sprouting seeds appear to be like those of other lupines (see Fig. c), but when the cotyledons open, they are seen tu be united by their broad bases. For two or three weeks the cotyledons enlarge; not only becoming broader, but thicker; yet we look in vain for a trace of the plumule. Meanwhile a white pustule has been growing, which finally bursts and discloses the partly grown leaves of the missing bud, which has all this time been hidden in the thick stem below the cotyledons! Now, the tough leathery skin of these cotyledons is proof against the nightly frosts that prevail at this season of the year (December), so they go on preparing food from the air with which to feed the tender plumule, until it also is strong enough to face Jack Frost. If you carefully examine these seeds in various stages of their growth, you will learn that the plumule is at the bottom of a short tube formed by the united petioles of the cotyledons. Sometimes the plumule breaks out through
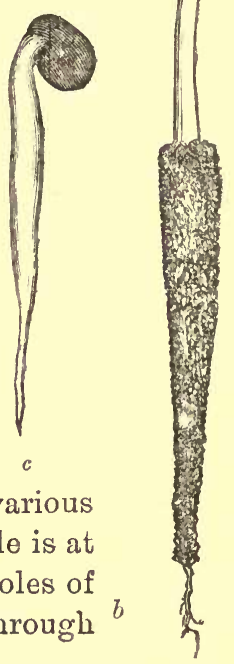
the side of this tube below the cotyledons, instead of bursting through between them.

Do not fail to see for yourself how squash embryos pry open their tough coats. Soon after the sprout has gained a foothold in the soil, a little knob grows on the side of the radicle so as to split more widely open the point of the seed coat, as s'lown in Fig. $c$. Then the radicle stem between the knob and the cotyledons, by growing, pries the seed still wider open, as seen at $b$ below. Finally, by continued growth, the cotyledons are pulled out of the seed coat and upward to the surface of the ground, where they expand, and become pretty good leaves. Seeds planted edgewise, which of course could rarely happen in nature, can not thus free themselves of their seed coats, and it has been proved by a French botanist (M. Flahault) that seeds which come up with their coats on do not thrive. The seed at $b$ in the figure was first planted the other side up. It was turned over when the knob on the right had begun to open the seed. The radicle, which then pointed directly upward, gradually straightened, bent downward, and finally the second knob grew, by the help of which the seed leaves were in a fair way to get out when the draw-

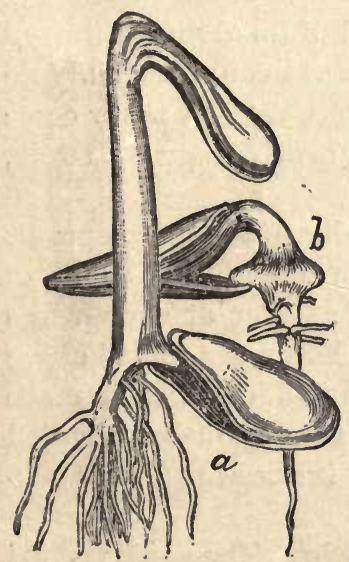
ing was made. Some native California plants get out of their coats in a similar manner.

Germination of Albuminous Seeds. You have observed that when seeds without albumen send their cotyledons above ground, the seed coats are usually left behind, but the albuminous seeds named in paragraph 5 retain their seed coats often for several days after they come up. Examine the coats after they are thrown off, and you will find none of the albumen which formed the larger part of their contents before germination. The enlarged cotyledons tell what has become of it, and it is now plain why the coats were retained. 

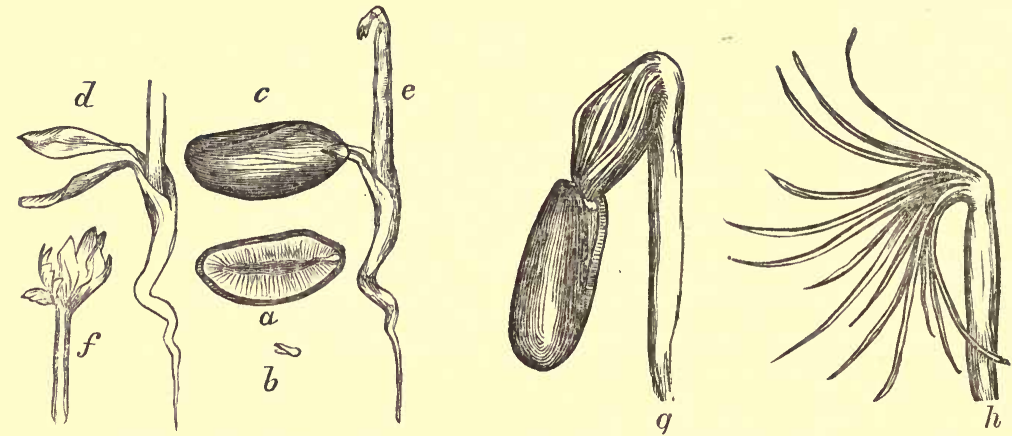

a. Section of a seed of Pæonia Brownii, showing the small embryo at the righi $\mathrm{n}$ the copious albumen. $b$. The embryo removed and the cotyledons separated. c. The germinating $\varepsilon e e d . \quad d$. Thc $\approx a m e$, with the seed coats removed $t$ ) show the leaf-like cotyledons. e. Plumule bud, or real end or ne unward-growing stem. $f$. The first plumule leaf as it appears above ground, the terminal bud ye: dormau! under ground. $g$. Seed of Pinus Sabinlana (Digger, Willow, or Nut Pine) soon after It axpears above ground. $h$. Same, with the seed coats removed to show the 14 cotyledons. See Fig 9, p. vi:

You must have wondered why the cotyledons of a bean, which never become leaf-like, should appear above ground. It is equally strange that the albuminous seeds of the peony should behave in the reverse way. As shown in the cut $(a$ and $b$ ), the embryo is very small. In germination the plumule comes up while the cotyledons become decidedly leaf-like, and fill the shell which has been emptied of its albumen to feed them and the plumule. These thin, veiny seed leaves could certainly do better work above ground than those of most lupines, jet they never come up. There is another curious thing about the growth of peony seeds, which you may try to discover.

When the buckwheat and cotton seeds have begun to sprout, you can study their embryos. Note how the thin, broad cotyledons of the former are folded once and rolled up with a layer of snow-white starch; and how the speckled seed leaves of the latter are folded alorg the center, then outwardly back, and finally crumpled endwise to make them fit coats too short for them. Maple seeds have curiously crumpled and folded cotyledons. Indeed, all seeds have interesting lessons to teach us.

Germination of Monocotyledonous Seeds. The seeds named 
in paragraph 6 do not clearly show their embryos in germination, but they are readily enough distinguished from dicotyledons. The downward growing sprouts are several instead of one, and the upward growing sprout is like a rolled grass leaf (Figs. 15 to 17). By tasting of the growing seeds you can discover what the starchy albumen is changed to before it is fit food for the young plant. It must be remembered that only the grass-like monoctyledons grow as here represented. If possible, get Lily seeds, Iris seeds, etc.

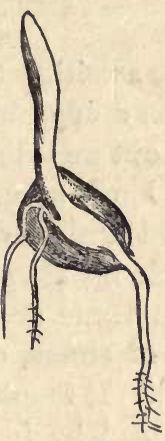

15

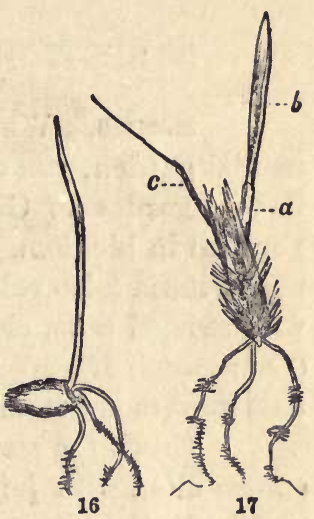

17

If you examine seeds and study their growth as you have been directed, you will have the evidence of your own eyes that an embryo is a plant in a 15. Germinating corn. 16. Wheat. 17. Wildoats; $a$, colorless sheath inclosing the first plumule-leaf $b$; $c$, the twisted and bent beard by means of which it is able to travel to cracks in the ground and thus plant itself. sort of sleeping state from which it may be aroused to activity by moisture and warmth. It will be evident that the radicle is a stem; that the cotyledons correspond to leaves, and that the plumule is a bud from which is to grow all the above-ground portion of the plant. Remember, that if these, or any other statements concerning the structure and behavior of plants, are not confirmed by your own judgment upon what you have yourself observed, they are useless to you, except as guides pointing to what you are to find. To memorize these statements of facts is to secure the husks, not the kernels, of knowledge. Plants themselves must teach you how they grow. The book can only show you how to question them and how to interpret their answers. Do not fail to carefully compare the results of all your experiments; for in this way you can decide what are general or usual facts, and what are exceptional. The latter should be closely investigated, since it is probable that there is a reason for all unusual as well as usual behavior of plants. 


\section{SECTION 2.-THE STRUCTURE OF PLANTS.}

Stems. While awaiting the development of germs in your experimental garden, you can study plants which have already reached maturity in wild gardens. Go out and dig up the first plant-not too large-that you find in blossom. I will suppose that you have found the very common Filaria (also called Pin-clover; and children call the curious seeds with twisted tails, clocks). Its parts are Roots, Stem, Leaves, and Flowers. (Some time, if you continue studying Botany, it will be proved to you that flowers are forms of stems, or stem-branches.)

Crush the stem. It is made up of stringy fibers and a soft substance filled with juice. The former is generally called Fibrous Tissue or Wood; the latter, Cellular Tissue. The lower part of the stem and the upper part of the root-the older portions of the plant-contain more wood than the branches and the rootlets, while the leaves have only net-like skeletons of wood. It would be interesting to study these tissues with the aid of a microscope, and thus become acquainted with the innermost structure of plants; but for the present it will be sufficient if you can distinguish, in a general way, wood from cellular tissue.

Cut the stem squarely across near the upper end, and from one piece take a thin slice. Stick this on a pin and hold it up to the light. It is nearly transparent, except a green ring of skin outside and a ring of white dots inside. The latter are cut ends of woody fibers which run lengthwise of the stem. Make a similar section of the lower part of the stem and you will find a continuous ring in place of the dots, showing that in the older part the fibers have become so numerous as to form a hollow cylinder of wood. The inclosed cellular tissue is called the Pith.

Exogens and Endogens. If the stem lives year after year there will be added successive layers of wood outside of the first one. Such stems are woody, and if they grow many years become Bushes, Shrubs, or Trees. Plants that grow in this way are called Exogens. Examine Asparagus, Soap-root, Iris, or any Lily and you will find the wood fibers scattered irregularly through the stems. 'These plants are Endogens. All our native 
trees and most other plants are exogens. Palm-trees, Century-plants, grasses, and the "small grains," are endogens.

Herbs are plants whose stems die, at least to the ground, after they have blossomed and matured fruit. These are Annuals when their lives are limited to one season; Biennials when they die the second year -not producing fruit the first year; Perennials when they live on year after year, their stems dying annually down to the ground. The underground portions of such stems are called-

Rootstocks. This name applies more particularly to such stems as grow nearly horizontally under ground, or become thick and fleshy with nutritious matter, which enables the plant to make rapid first growths each year. A rootstock can usually be distinguished from a true root by its bearing buds.

Bulbs are formed by a peculiar bud growth in which the leaves or their bases become very thick and fleshy, with a store of nourishment, while the stem grows in diameter, but scarcely at all in length.

Coated or Tunicated Bulbs are those in which the leaves form a succession of envelopes, as in the onion. If the leaves or leaf-bases are narrow, as in the lily, the bulb is Scaly.

Corms resemble bulbs, but are solid, and have more the nature of Tubers, which are the thickened ends of slender, branching, underground stems, as potatoes, ground artichokes, etc.

Leaves. Collect the leafy stems of many kinds of plants. Observe the arrangement of the leaves on the stems. A few like Erodium (Filaria), the Catchfly, Pink, Fuchsia, Mint, etc., have Opposite leaves. Possibly you may find a Collinsia, or stem of Cleavers, with the leaves in Whorls of three or more. Most plants have Alternate leaves. You will find some plants like Plantain, with a bunch of leaves growing from the ground, but no leafy stems. Such leaves come from rootstocks, and are said to be Radical. Plantain, Dodecatheon, Primrose, etc. have the leaves all radical. Many perennial herbs have radical leaves, as well as ordinary stem leaves, and these usually differ more or less from the stem leaves.

Observe that stems and branches end in buds or flowers, and that 
there is usually a bud, or branch, or a flower at the base of a leaf between it and the stem from which it grows.

Buds and flowers at the ends of stems or branches, are Terminal; when between the stems and leaves, Axillary.

Examine the leaf of a Violet or Pansy. You can readily distinguish three parts: A broad Blade; a stem or Petiole, and a pair of appendages at the base of the petiole called Stipules. The latter in the Pansy are leaf-like. Sometimes they are mere scales, and frequently there are none at all. The petiole may be wanting, also; the leaf is then said to be Sessile. Leaves with but one blade are-

Simple Leaves. The illustrations (Figures 18 to 32 ) show the principal forms of simple leaves or leaflets of compound leaves. Carefully compare the blades of your leaves with these shapes. If the leaf in hand does not correspond with any of the figures, you may describe it by combining the descriptive words, or by adding a word. A leaf, for example, too broad to be lanceolate, and narrower than ovate, if about half way between the two forms, is Ovate-lanceolate or Lance-ovate; the first, if nearer ovate; the latter, if nearer lanceolate. Or, if merely a little broader than lanceolate, we may say it is Broadly-lanceolate; when more slender, Narrowly-lanceolate; if slender and nearly as broad in the middle as nearer the base, it is Linear-lanceolate, etc. So, too, there are interme-

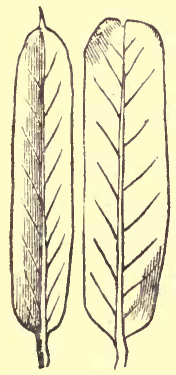

$18 \quad 19$

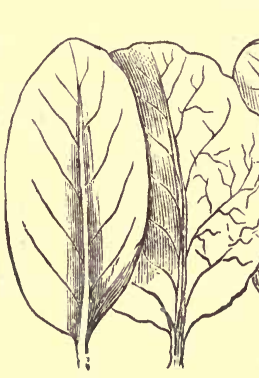

2021

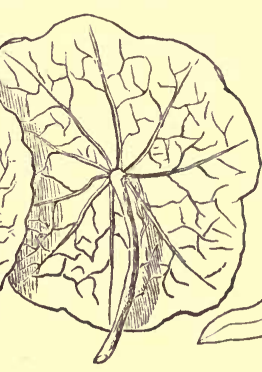

22

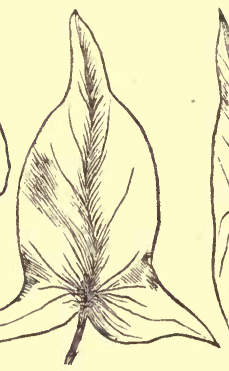

23

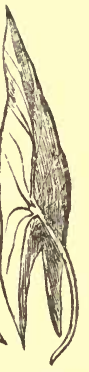

24

Forms of Leavfs.-18. Linear. 19. Oblong. 20. Elliptical. 21. Orbicular. 22. Peltate (Shield-shaped). 23. Hastate (Spear-shaped). 24. Sagittate (Arrow-shaped).

diate forms described by such terms as: Oblong-lanceolate; Narrowly-elliptical; Broadly-elliptical-which approaches orbicular; Broadly-cordate- 
which becomes reniform if the aper, is rounded, etc. Obovate; Oblanceolate; Obcordate, etc., apply to forins the reverse of ovate, lanceolate, etc.

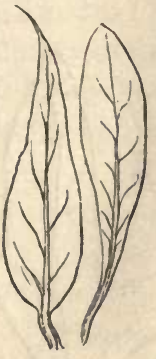

2526

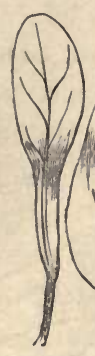

27

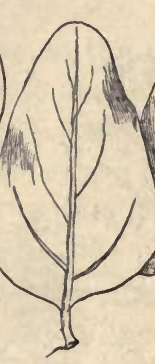

28

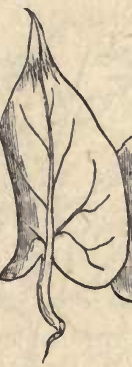

29

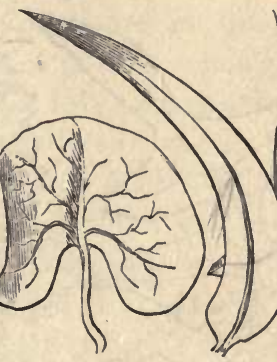

30

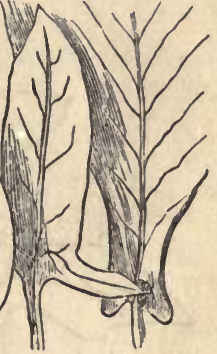

$33 \mathrm{a}$

Forms of Leaves.-25. Lanceolate. 23. Oblanceolate. 27. Spatulate. 28. Ovate (Eggshaped). 29. Cordate (Heart-shaped). 30. leniform (Kidney-shaped). 31. Falcate (Sickiochaped.. 32. Hastate (Spear-shaped). 32a. Auriculate (Eared) base.

Apexes of Leaves. There are terms descriptive of the apexes (the upper ends) of leaves. Fig. 18 has a Cuspidate apex; Fig. 19, Notched or Emarginate; Figures 23, 24, 29, Acute; Fig. 25, Acuminate; Fig. 26, Obluse.

Margins of Learcs. All these forms are represented as having

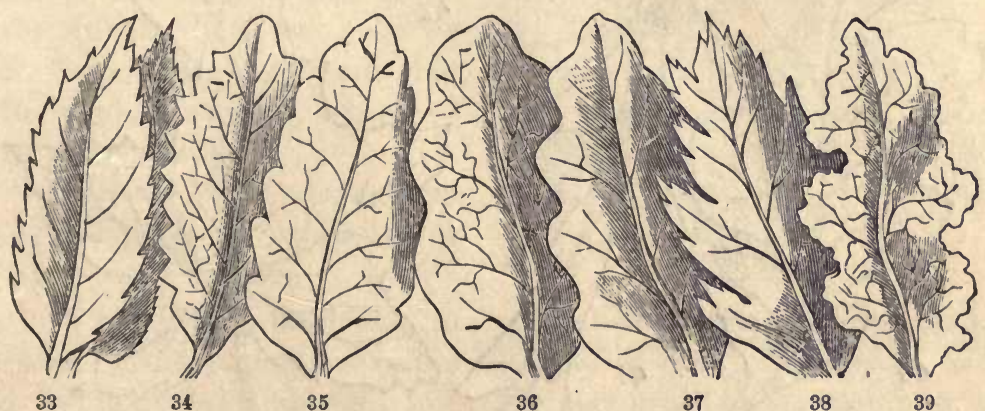

I.Ar Margixs.-33. Serrate. 34. Dentate. 35. Crenate. 36. Wavy. 37. Sinuate. 38. Incised. 39. Erose.

entire or nearly entire margins, but the margins may be notched or cut in various ways. Figures 33 to 39 will assist you in describing the margins of your leaves. Here, also, you will find it necessary to combine ad- 
jectives or use adverbs. Leaves may be Finely-serrate or Coarsely-serrate; and Dentate, Crenate, etc., may be similarly modified.

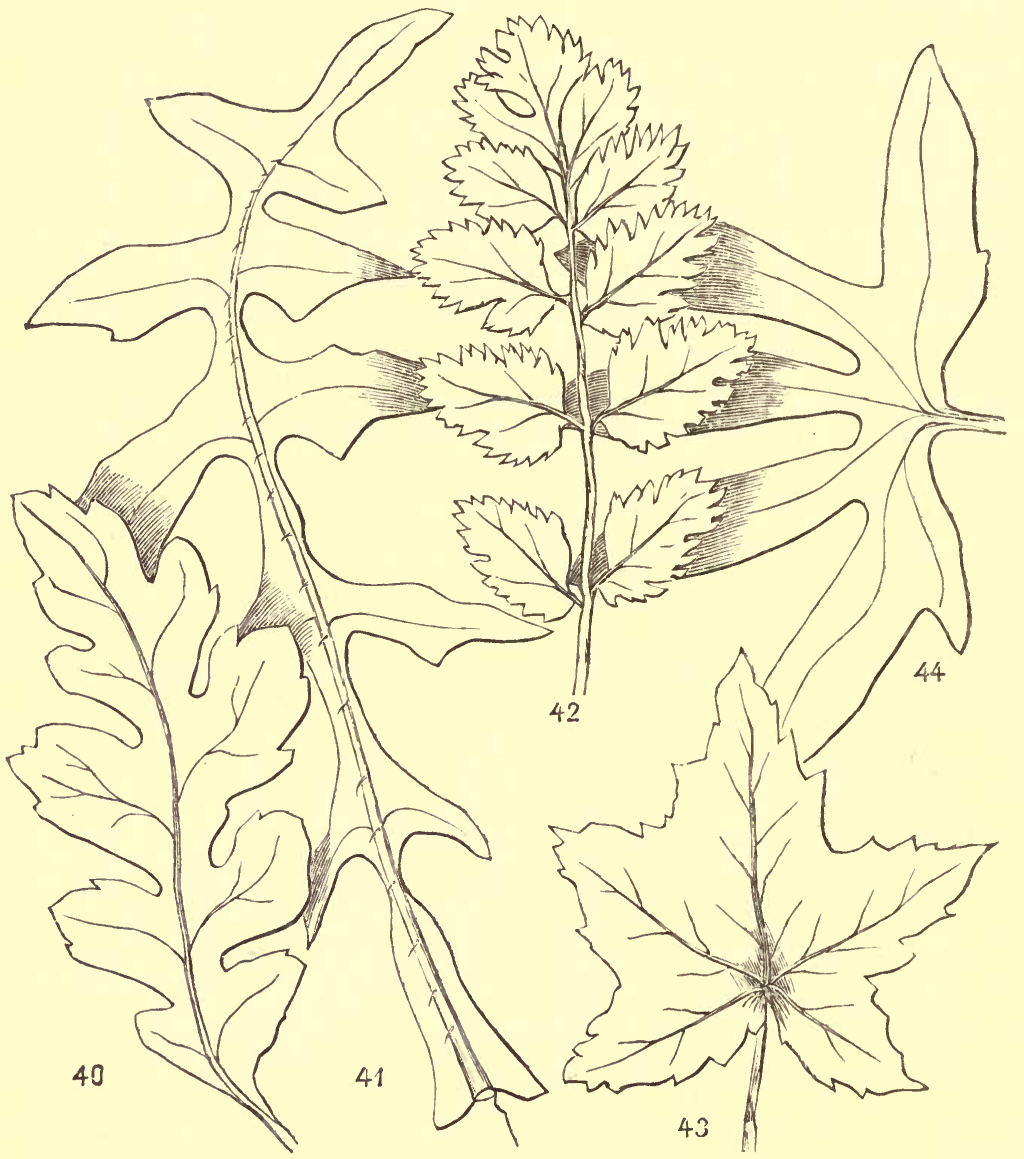

40. Pinnately lobed leaf, of White Oak (Quercus lobata). 41. Tinvately parted leaf of Nemo. phila aurita (Lobes retrorse). 42. Pinnate leaf of Erodium moschatum. 43. Pulmately loved leaf of Muple. 44. Palmately parted leaf of Viola lobita.

Lobed Leaves. These may be Pinnately or Palmately lobed, depending upon whether there is more than one rib proceeding from the 
base of the leaf. Fig. 40 represents a pinnately lobed leaf; Fig. 43 , palmately lobed. When leaves are deeply lobed, as in Figures 41 and 44, they are said to be Parted. Divided leaves are cut quite to the midrib if pinnately divided, or to the end of the petiole when palmately divided. Cleft leares have the sinuses between the lobes sharp as in Fig. 38. When leaves are pinnately cleft about half way to the midrib they are said to be Pinnatifid. If the lobes are pinnatifid it is described as Bipinnatifid. It is common to give the number of lobes in the descriptive phrase, as pinnately nine-lobed (Fig. 40); pinnately eleven-parted (Fig. 41); palmately five-lobed (Fig. 43); palmately five-parted (Fig. 44).

Compound Leaves have distinctly separate leaflets usually jointed to a common petiole, just as simple leaves are jointed to the stem. A leaf is Pinnate, when the leaflets grow along opposite sides of the petiole (Fig. 42); Palmate, if they all grow from the end of the petiole (Fig. 46). Fig. 45 represents a pinnately 3-fuliolate leaf; Fig. 46, palmately 3 -foliolate. When there is no odd leaflet at the end the leaf is $a b$ ruplly pinnate. Leaves may be twice, thrice, etc., compound, that is, the leaflets may be compound as in some acacias.

Bracts are leaves among flowers, or small undeveloped leaves anywhere on the stem.

Stipules may be adnate to the base of the petiole, as in the small stlpules. 46. Palmately or digitately 3-foliolate rose and clover (Figures 45,46); they may grow on the stem; or, as in some plants of the Buckwheat Family the stipules form a sheath surrounding the stem at the base of the petiole. Do not mistake the first leaves of a growing axillary bud for stipules.

Venation of Lraves. All the leaves thus far described are said to be Netled-reined or Iicliculated, because their skeletons of wood fiber 
resemble nets. Examine the leaves of Iris, Calla, or any that are grasslike, and you will see why they are called Parallel-veined.

Netted-veined leaves grow on Exogenous stems. Parallel-reined leaves grow on Endogenous stems. The former belong to plants which grow from Dicotyledonous seeds; the latter to plants from Monocotyledonous seeds.

Flowers. Get a bunch of Mustard flowers-Tall-flowers, single Stock, or Radish flowers will do as well. Pluck a single blossom and note these facts: The most conspicuous part consists of four yellow leaves; outside of these are four smaller greenish yellow leares in pairs not quite alike. The latter are Sepals, and together form the Calyx; the former are Petals, and together form the Corolla. Pull off the sepals, observing that they alternate with the petals. Next remove the petals. The broad part of each petal is called the blade, the narrow part, the claw (corresponding to the petiole of an ordinary leaf). Inside of the petals you find six yellow-headed bodies with white stems, two of which are shorter than the remaining four. These are the Stamens. Their stems are Filaments; the yellow heads are Anthers, and the yellow powder which they contain is Pollen. In the center of the flower is a club-shaped body called the Pistil. 'This is the young seed-pod, and by splitting it open you may see the minute Ovules, which are the beginnings of seed. The part containing the ovules is the Ovary; the naked upper end of the pistil is the Stigma, and the part connecting the stigma with the ovary is the Style. The end of the stem upon which the parts of the flower grow is the Receptacle, and the stem is called a $\mathrm{Pe}$ duncle. Fig. 47 will assist you in learning these names.

$$
\text { A Complete Flower }
$$

must have calyx, corolla, stamens and pistils; but, since the office of a flower is to produce seeds, and these grow from ovules, which pollen has reached by way of the stigma, it follows that

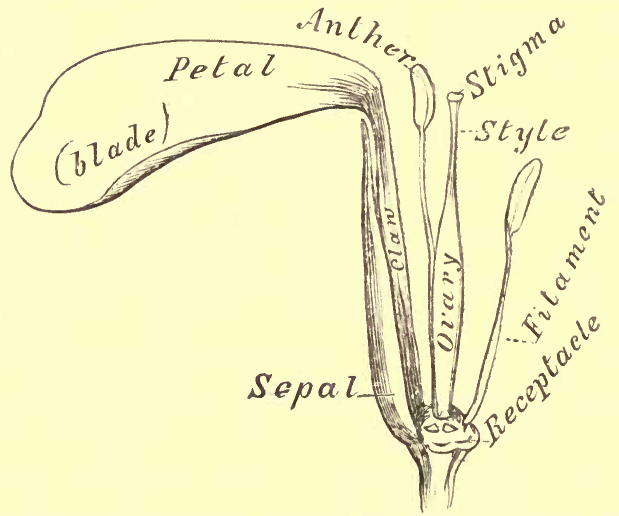

47. Magnified Mustard flower with four of the stamens, three petuls and three sepals removed. 
A Perfect Flower may consist of pistils and stamens only, and of these the styles and filaments are not essential.

Cohesion of $F^{2}$ loral Organs. When sepals cohere or grow fast to each other (Figs. 4851) the calyx is Gamosepalous. So, also, the corolla may be Gamopetalous. When stamens cohere they are Monadetphous if in one set, Diadelphous if in two sets (usually 9 and 1 ), etc. Cohering pistils (carpels) form a Compound Pistil. The degrees of cohesion in calyx and corolla is described, as in leaves, by the terms entire, cleft or lobed and parted. Thus: Bindweed (Fig. 50) has an
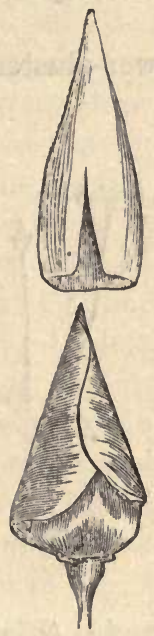

48
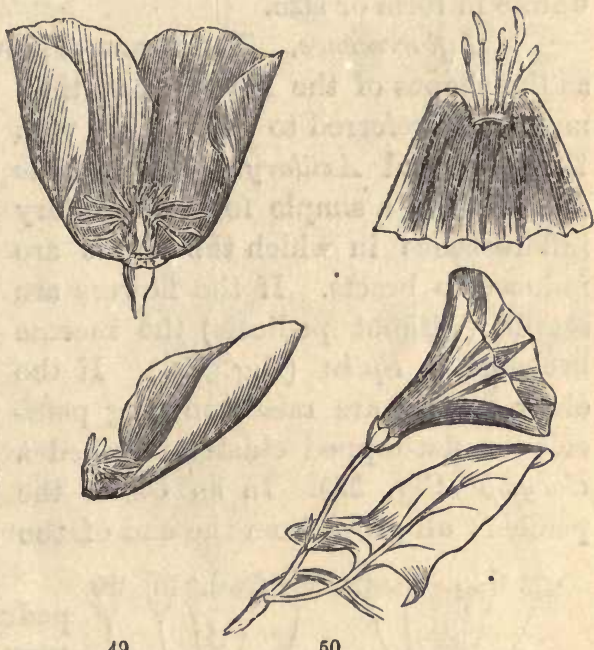

50

48. Bud of Eschseholtzia, with the mitriform calyx removed ard shown above. 49. (Open fluwer of the same, with two of the p+tas removed, one of these below with the stamens adhering to the claw. 50. Flower and leaf of Convolvulus arvensis; above is the curolla split down, displaying five unequal stamens.

entire corolla limb; Zauschneria (Fig.51) has a 4-lobed calyx; Nemophila has a 5-parted or deeply 5-lobed corolla, etc. If the flower has a limb (border) distinct from the tube, these terms apply to the limb.

Adhesion of Floral Organs. The calyx may grow fast to the ovary (Fig. 51), then it is said to be Superior (ovary inferior). The corolla and stamens frequently grow on the calyx, as in Fuchsia, Strawberry, etc.; then they are said

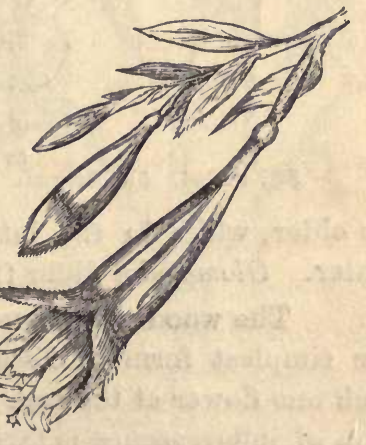


to be Perigynous; or the stamens may grow on the corolla (Fig. 50) as in most gamopetalous flowers, and in Eschscholtzia (Fig. 49). In the Orchis Family the stamens grow on the pistil.

Irregular Flowers are those in which parts of the same kind are unlike in form or size.

Inflorescence. The forms of flower-clusters are almost as various as the shapes of the flowers, but they may all be referred to two plans, viz.: Terminal and Axillary. The Raceme (Fig. 52) is a simple form of axillary inflorescence in which the leaves are reduced to bracts. If the flowers are sessile (without pedicels) the raceme becomes a Spike (Fig. 53). If the older flowers are raised on long pedicels the flat-topped cluster is called a Corymb (Fig. 55). In an Umbel the pedicels all grow from the end of the

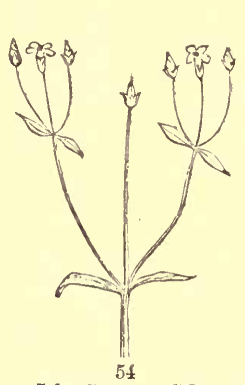

54. Cyme. 53. Spilie. 52. Raceme.
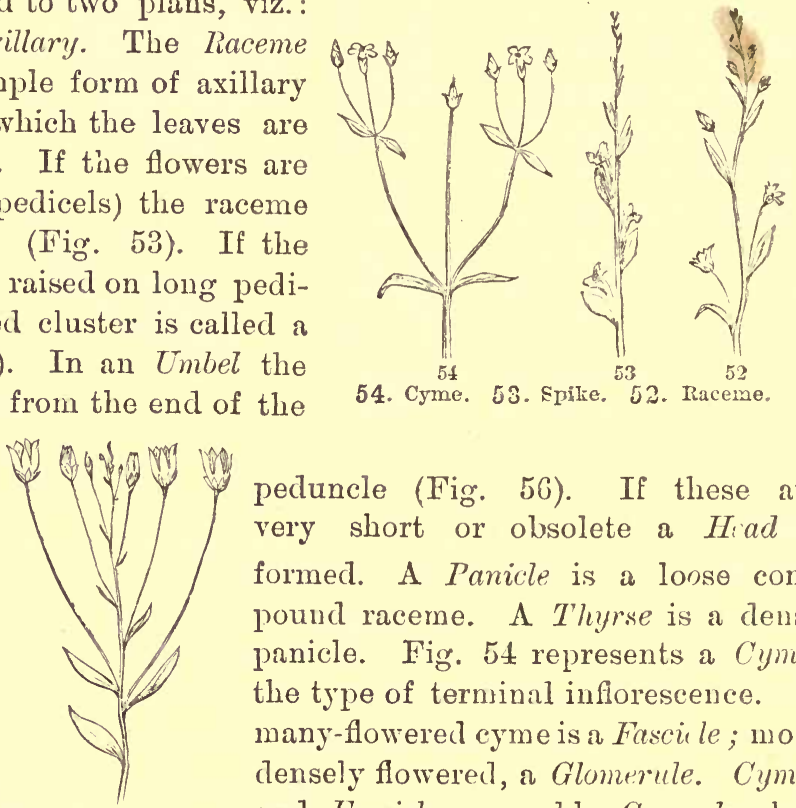

5.5

peduncle (Fig. 56). If these aro very short or obsolete a Hiad is formed. A Panicle is a loose compound raceme. A Thyrse is a dense panicle. Fig. 54 represents a Cyme, the type of terninal inflorescence. A many-flowered cyme is a Fascile; more densely flowered, a Glomerule. Cymes and Fascivils resemble Corymbs; but

55. Umbel. 55 . Corymb. in the former, the central flowers are the older, while in the latter, the younger flowers or buds occupy the center. Glomerules differ from heads in the same way.

The woodland flowers Trillium and Anemone furnish examples of the simplest form of Terminal Inflorescence. Their simple stems bear each one flower at the top. Often flowers seem to be axillary when the plan of inflorescence is terminal. Fig. 57 illustrates a case of this kind. 
Suppose that one of the branches in Fig. 54 had failed to grow. The first flower would then appear to be axillary. In the plant represented by Fig. 57, two of each set of three axillary buds usually remain dormant. Their growth would complete a Trichotomous Cyme. Fig. 54: represents a Dichotomous Cyme. Imagine the plant shown in Fig. 57 to continue branching, the stem to be shortened so as to bring the flowers close together, and the leaves to become obsolete. A bunch of flowers, having the appearance of a one-sided raceme, would be formed. Let the flowers become sessile, and we would have a false spike. Such mimic racemes and spikes are usually coiled as shown in Fig. 64 .

The common Anagallis, whose
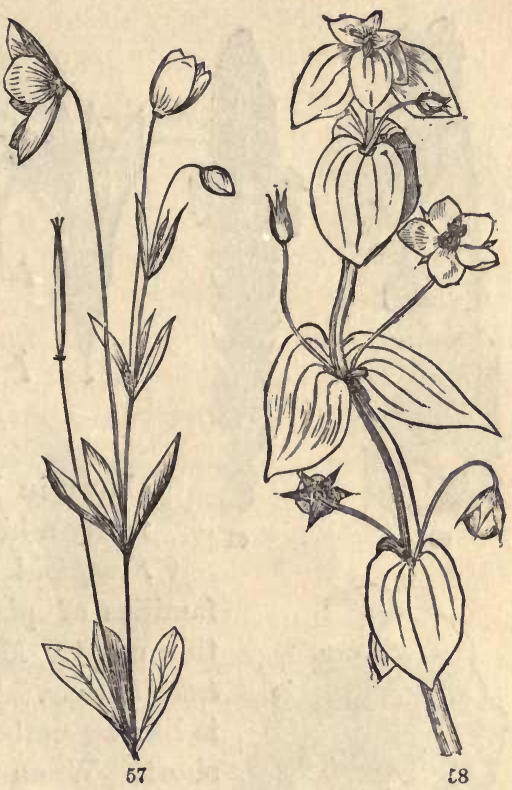

pretty salmon-colored flowers appear in the axils of the opposite leaves (Fig. 58), is an illustration of simple Axillary Inflorescence. Imagine the leaves reduced to bracts, and the stem shortened. The fruit, flowers, and buds would then form a Bracteate Raceme. Let the bracts become wanting, and we would have a naked or Bractless Raceme, similar to the one shown in Fig. 59. This raceme wants only a slight lengthening of the lower pedicels to become a Corymb. Indeed, it might be called a Corymbose Raceme. Fig. 60 represents a naked raceme, in which only one or two flowers are in

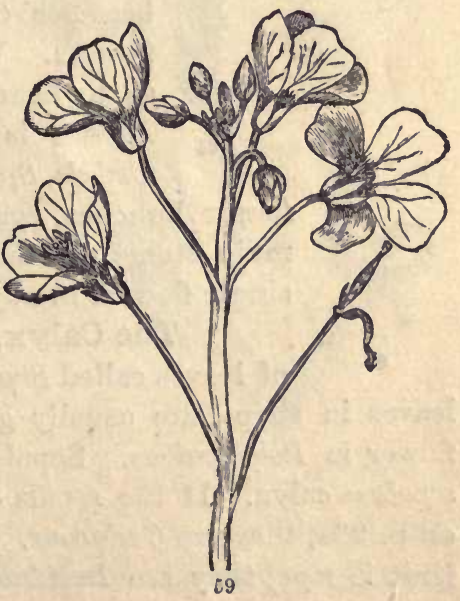




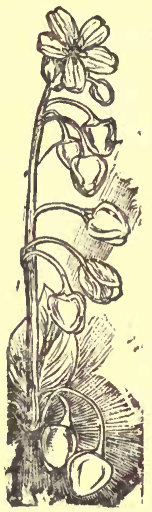

60

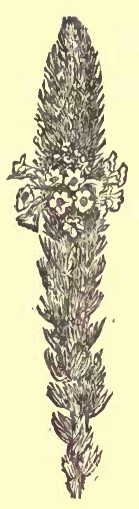

61

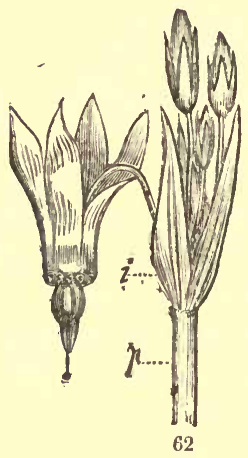

shown in Fig. 61. The coiled spike (Fig. 64) is really a kind of cyme, as has been shown. This Scorpioid Inflorescence is characteristic of two

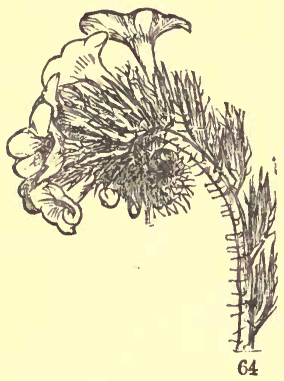
families of plants, represented by many plants on this coast. Mosquito Bills (Fig. 62) grow in Bracteate Umbels. The Head or Capilate cluster (Fig. 63) is like an umbel, only the pedicels are mostly very short. When the flowers are numerous, the head becomes Globose. The true clovers have capitate flowers. When the pedicels in a raceme branch so as to bear two or more flowers each, a Compound Raceme is formed. So in like manner Compound Umbels, Spikes, and Corymbs may be formed. These

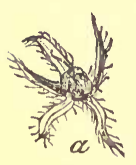

65

flower bunches, cymes, racemes, etc., may be at the ends of main stems or branches, or in the axils of leaves, or replace single flowers in any kind of inflorescence.

The Calyx, as we have already learned, is composed of leaves called Sepals, which, though different from ordinary leaves in shape, are usually green. When the sepals are separate, the flower is Polysepalous. Sepals united partly or wholly form a Gamosepalous calyx. If the sepals drop off when the flower opens, as shown on p. 20a, they are Caducous. If they fall with the petals, or before the fruit is ripe, they are Deciduous. A Persistent Calyx remains until the 
fruit ripens (Fig. 65). A colored calyx-i. e., not green-is said to be Petaloid. Flowers without petals and those of the Lily Family usually have petaloid sepals (Figs. 66, 70, 71).

The Corolla is Polypetalous when the petals are free from each other (see Figs. 66, $68,69,73)$. In Gamopetalous corollas there are all degrees of cohesion from the complete union (Fig. 67) of the Entive limb to the almost free petals of a Divided corolla (Fig. 58). Petals often grow upon the calyx (Fig. 68). Corollas are Regular (Figs. 67, 69) or Irregular (Fig. 66 , and Fig. 58, p. 3. See also the figures on p. 11 and p. 88b). Common forms of regular corollas are Rotate(Fig. 58), Salverform (Fig. 64), Funnel-form
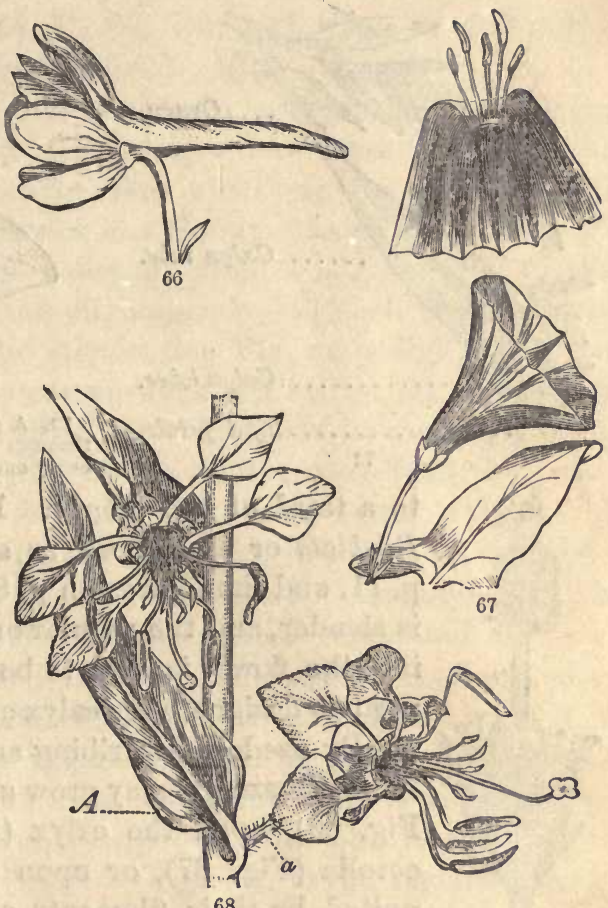

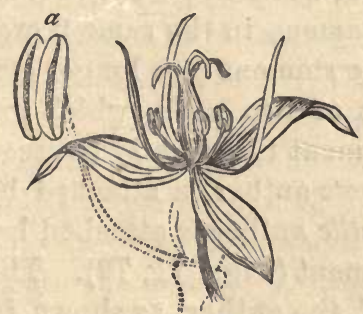

69

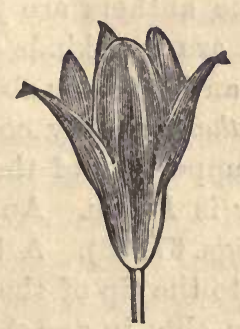

70

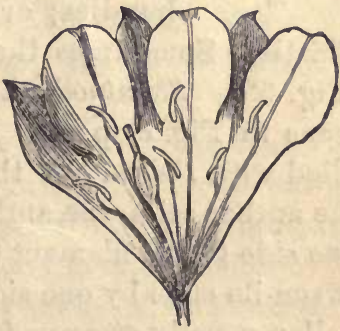

71

(Fig. 67), and Campanulate or Bell-shaped when the tube expands suddenly at the base to a width nearly equal to that of the summit and about equal 


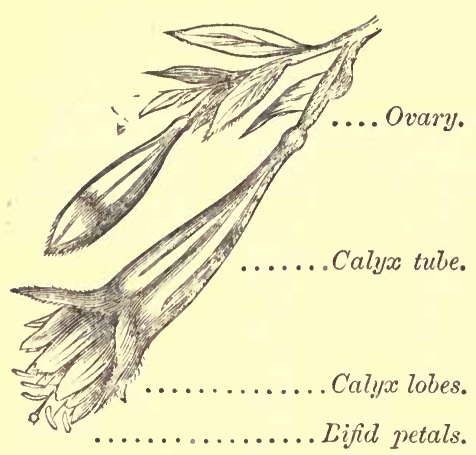

72

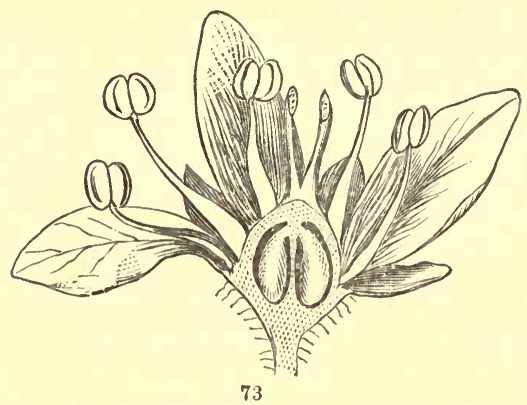

73. A flower of Whipplea, magnified, cut down through the center, showing tho partly inferiur ovary aud the introrse unthers.

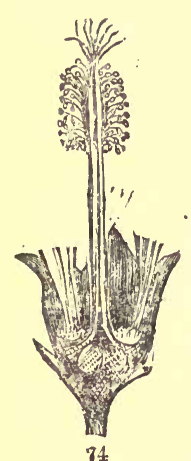

to a third of the length. Irregular flowers are frequently Bilabiate or Two-lipped, as shown in the figures $a$ and $c$ on p. 11, and the figures on p. $88 \mathrm{~b}$. When the tube of a corolla is slender, and the regular or irregular limb is small or wanting, the flower is said to be Tubular. The term Perianth is used to designate the caly $x$ and corolla taken together. It is mostly used in describing endogenous flowers (Figs. 70, 71).

Stamens rnay grow upon the receptacle (Hypogynous, Fig. 69), ripon the calyx (Perigynous, Fig. 68), upon the coroila (Fig. 67), or upon the pistil. Stamens are often united by their filarnents so as to form tubes (Fig. 74) or bundles; or the anthers are joined, as in the Sunflower or Thistle. Sometimes there are two kinds of stamens in the same flower (Fig. 68). Staminodia are antherless or abortive stamens (see longer stamens in Fig. e, p. 8). Anthers usually consist of two cells, which are filled with Pollen. If the upper end of the filament lies exactly between the anther cells, the anther is Innate. An Adnate anther is attached by one side to the filament (Figs. 67,68). A Versatile anther is attached between its ends by one side to the tip of the filament (Figs. 71, 72). The pollen usually escapes from slits in one side of the anther, as shown in Fig. 69. This side, which in an adnate or versatile anther, is opposite the filament, is called the face of the anther. When the anther faces 
the pistil, it is Introrse (Figs. 68, 71, 72, 73); and when it faces away from the pistil, it is Extrorse (Fig. 69).

The Pistil grows upon the receptacle, or upon a stem arising from it, called a Stipe (Fig. 71). In a few orders there are several or many pistils in each flower. Usually there is but one, formed of several simple pistils (carpels) united more or less closely. As in the other floral organs, there are all degrees of colesion, from a slight union of the bases of the ovaries-rarely of the stigmas only-to such completeness as leaves no trace of lobes in the stigma (see Fig. on p. 5). Often the free styles tell how many carpels compose the pistil (Fig. 69). Generally the stigmas are divided or lobed (Fig. 68). These marks wanting a cross section of the ovary, or, better still, of the partly grown fruit, will usually shew a cell for each carpel (see the right-hand figure, p. 88b). If the ovules (or young seeds) are in the center or grow on more than one side of the ovary (or pod), the pistil is compound. A simple pistil is generally plainly one-sided. A symmetrical pistil is compound.

Inferior Ovaries. When the calyx adheres to the ovary, so as to form, after the ovary has matured, the outer part of the fruit, it is said to he superior, because the apparent calyx, its lobes, or cup, seem to grow upon the ovary. For the same reason the ovary is said to be inferior (Figs. 68, 72). There are all degrees of adhesion, from the slight union at the base, as seen in Whipplea (Fig. 73), to the remarkable extreme exhibited in the plant figured on p. 5 , in which not only the ovary, but several inches of the style, is adherent to the calyx. When the adhesion is only partial, it can be shown by cutting the flower vertically, as represented in Fig. 73 .

The Fruit is the ripened ovary (or set of ovaries), and all that directly belongs to it. A dry fruit which opens in any way to let out the seecls is called a Pod. A pod formed by the growth of a simple pistil (one-carpeled) is called a Follicle when it splits only along the side which bears the seeds. A Ligume splits down both edges. Pods formed of several carpels are called Capsules. Akenes are dry, indehiscent, seedlike fruits, containing but one seed. Utricles are distinguished from akenes by their thin coats, which are too large for the inclosed seed. 


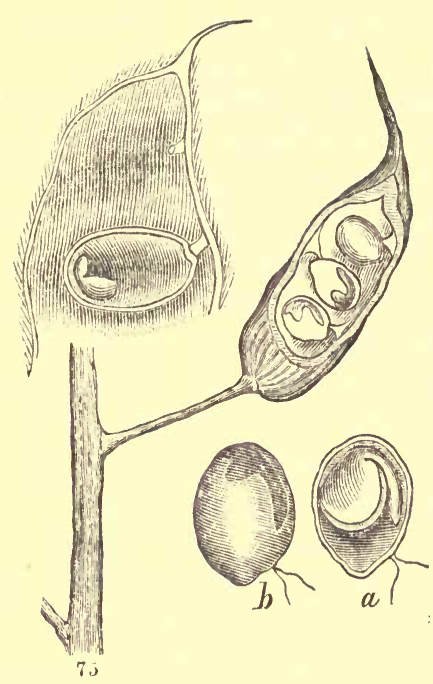

There are many other names applied to fruits, which it is not necessary to define here.

The Growth of Ovules. You can not study the development of ovules from the beginning, without the help of a compound microscope, but you can easily observe all stages of growth, from a tiny green speck to the full-grown embryo. Most seeds are nearly full grown in appearance before the embryo is more than fairly visible to the naked eye. The seed coat, filled with a syrupy or milky, usually sweet, liquid, appears to constitute the very young seed. With a sharp knife cut in halves a great many green peas, in size from half grown upward. You will surely find in some of them tiny green embryos, and you may get specimens from the size of a pin's head up to those which tightly fill the seed coat. In Fig. 75, at the top, is seen-magnified two diameters-the young seed of a lupine, cut so as to show the young embryo lying in one end. In the same figure is represented a radish pod, laid open so as to show three of the seeds, two of which exhibit their partly grown embryos.* Below, at $b$, is one of these magnified, and at $a$ an older one, also magnified. The grown embryo completely fills the seed. Observe the positions of the embryos in relation to the stems of the seeds and the stems of the pods. The lower seed in the radish is fastened to the lower side of the pod, the middle seed grows to the upper side. The cotyledons increase much more in size than the radicle. The embryo evidently grows, in part at least, by absorbing the liquid around it. Suppose the embryo of the lupine to quit growing at the size represented in the figure, and that the liquid around it thickens until it becomes solid. Would not the seed thus formed be albuminous?

* These are cut in two. The embryo may be secn thronga the sted coat, as l eprescuted at $b$, by hold ing it up to the light. Half of the seed-coat is removed from $a$. 


\section{SYSTEMATIC BOTANY.}

\section{NAMES OF PLANTS: CLASSIFICATION.}

In a general way we designate the objects around us by single names. We speak of a stone, a wolf, or a pine; but to distinguish the kinds we naturally use two names, as lime stone, sand stone; grey wolf, prairie wolf; nut pine, yellow pine, etc. This is one step in classification, and the only one commonly taken. This natural plan of double names was adopted by the great naturalist, Linnæus, who gave names to most European plants, as well as to many of this continent. He wisely gare the Latin form to his names, since that language (being the base of most languages spoken in civilized countries) is the natural source of cosmopolitan names-those truly common to all people. Botanical names, then, differ from so-called common names principally in form, and they have these decided advantages: they more exactly represent the relations between kinds of plants, and they are names that are common to people of all languages. In short, they are the true common names.

It is not true that botanical names are harder than local names. The most common of our ornamental plants are well known by their scientific names. No one thinks of calling the following botanical names hard: Geranium; Aster; Verbena; Petunia; Por. tulaca; Crocus; Phlox; Fuchsia; Iris; Magnolia; Oxalis; Azalea; Dahlia; Lobelia; Arnica, etc. Most people talk familiarly of Camellias, Callas, Begonias, Acacias; etc.: while our beautiful California plants, Clarkia, Collinsia, Eschscholtzia Nemophila, etc., are well known by their proper names - at least, in other countries.

Generic Names correspond to the second parts of the compound common names, as oak, pine, rose, etc. Some of these are the old Greek or Latin names of the plant. Most generic names are either derived from Greek or Latin words descriptive of some peculiarity of the plant, or they are commemorative of some botanist, as Thysanocarpus, from Greek words meaning fringe and pod; Kelloggia, in honor of Dr. A. Kellogg, a veteran botanist of this coast. Sometimes genera are named in honcr of those who are not botanists, as Fremontia, Hollisteria, etc. 
Specific Names are adjectives corresponding to the first parts of common names. They are usually descriptive of some characteristic of the plant, as Gilia liniflora, Flax-flowered Gilia. Frequently a species is named for the discoverer, as Gilia Bolanderi, Bolander's Gilia; often for the country where it was first found, or where it abounds, as Ranunculus Californicus, California Buttercup. Sometimes there are varieties of a species as Trifolium barbigerum, Var. Andrewsii, Andrews' Bearded-Clover.

Orders and Classes. Genera are grouped in Orders or Families, and these in Classes. There are two classes of flowering plants, Exogens and Endogens.

\section{ANALYSIS OF PLANTS.}

This whole matter of naming and classifying can be well understood only after you have analyzed many plants; $i$. e., you must have carefully examined them part by part, and patiently compared their peculiarities with the descriptions in the Flora until you have determined their uames. In the beginning there will be many failures; but do not allow them to discourage you, for each victory will make the way easier to other conquests.

Choose for your first studies plants with large flowers. Do not attempt to determine the name of a plant unless you lave specimens which show the kind of inflorescence and the arrangement of the leaves on the stem. If possible, secure specimens of the fruit and the roots. If in any plant you cannot readily distinguish the parts of the flower and their relations to each other, lay it aside until the study of easier plants has given you more skill.

The first thing to be determined in analyzing a plant is the Class; i. e., you must decide whether it is an Exogen or an Endogen. You have learned in the preceding lessons how the seeds and stems of these two Classes of Flowering Plants differ. Usually, however, the leaves and flowers sufficiently distinguish the class. In our plants, if the leaves are parallel-veined; or, if the parts of the flower are in threes the plant is an endogen. In other words, if there is no network of intersecting fibers between the ribs of the leaves the plant is an endogen; if the flower has 
three sepals and three petals (i.e., a perianth of six leaves or lobes), three or six stamens and three or six pistils (generally united to form a compound pistil with a three or six-celled ovary) the plant is an endogen. When the leaves are netted-veined, and the parts of the flower are not all in threes, the plant is an exogen.

It is a good plan to write out a description of a plant before attempting to ascertain its name. The parts may be described in this order: Roots, Stems, Leaves, Flowers, Fruit.

You may find a smooth plant bearing a loose raceme of red flowers, one of which is represented in Fig. 57. The floral leaves are all colored, but there are evidently two sets; viz.: a calyx of 5 sepals inclosing a corolla of 4 petals. The parts of the flower, then, are not in threes; and, since the palmately lobed leaves are netted-veined the plant must be an exogen. Turning to the key, we proceed as follows:

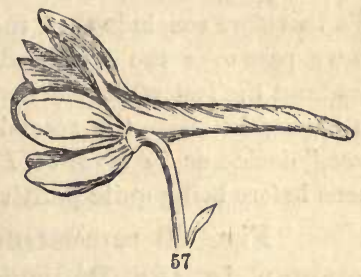

The plant must belong in "Division 1 ," since by carefully removing the sepals and petals we find that the latter are separate from each other. It must be found under "A," for there are many stamens. The stamens are free from the caly $\mathrm{x}$ and corolla, i. e., they are hypogynous; so we read the next line: "Pistils, few to many distinct carpels, rarely one." Our flower has three distinct carpels, therefore we feel sure that it must be sought under one of the next five equal lines beginning with "Calyx." As the calyx is easily shaken off from the older flowers we decide that it is deciduous. The juice is colorless also. We turn, therefore, to RAvunculaces, p. 16. The description of the order is satisfactory. The key to the genera begins with the heading " *Flower's regular." Ours is not, for the upper sepal is unlike the others. " "** Flowers irvegular"; colored sepals conspicuous," is right. We now choose between "Upper sepal spurred,'

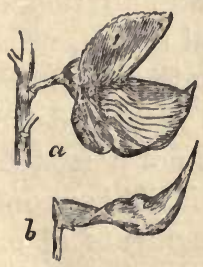

58

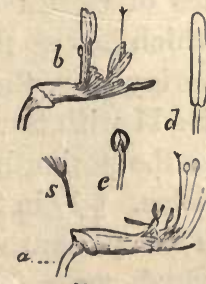

59 and "Upper sepal hooded." Evidently the first is right, and the genus is Delphinium. We find that the generic description on p. 18 fits our plant. The last species being tho only one with red flowers, we decide that our plant is Delphinium uudicaule, or the Naked-stemmed Larkspur.

The order Leguminosæ, or the Pea Family, is one that you will soon 
learn, since its characteristics are well marked. We will suppose that you have before you a very common blue-flowered shrubby plant belonging to that order, a single flower of which is shown in Fig. 58. Knowing the order, you turn at once to p. 38 , and begin to use the key to the genera.

Carefully removing all the petals, the stamens and pistil appear as in $a$, Fig. 59 . The filaments are united for the greater part of their length into a tube which incloses the ovary as a sheath does a knife. Of the three sections in the key, then, it is evident that the second is to be taken. Since some of the anthers have shed their pollen, aud others have not, it is safe to say they are of two kinds-a bud will show the difference better (b, Fig. 59.) Moreover the leaves are digitate, and have more than three leaflets We therefore conclude that the third genus is the one. Our plant is slightly shrubby, so we pass over the first heading in the synopsis of species. Of the second and third headings the last seems the most likely to lead us aright. Our flower is blue, so we have to choose between the second and third species. The words "Slightly wooly at the base," decide us in favor of Lupinus Douglasii, though we should examine more specimens before being quite positive.

Fig. 60 represents a flower of a plant common in the Redwood forests. Three or more of the dull-colored flowers grow in an umbel on a very short scape between a pair of spreading radical leaves. Since the leaves have parallel veins, and the parts of the flower are in threes, we must use the Analytical Key for Endogens, p. 13. You will have no difficulty in referring the plant to the Order LiliaCEE. To make the analysis of a plant in that

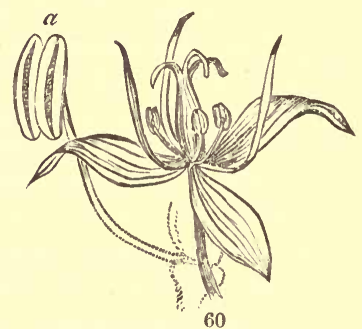

60. Flower ne S oliopus, a, ono of the stamens magnified, showing large order easy, the genera are grouped in the bursting anther cells. three Series. Reading the characteristics of Series I, we find they do not correspond with those of our plant, which has no floral bracts, which has the stamens hypogynous instead of perigynous, the anthers extrorse instead of introrse, etc. Comparing Series II with Series III, we decide that our plant belongs in the former, since the perianth is not persistent, and the flowers are not in racemes or panicles. $\$ 1$, in Series II is wrong, for our plant has no leafy stem. Since the perianth segments of our flower are dissimilar we try $\S 3$, under which we refer our plant to the 
genus Scoliopus. Turning to the description of the only species described, we find it satisfactory. Upon referring to the Glossary of Generic and Specific Names in the back part of the book, we find why the plant was named Scoliopus Bigelovii.

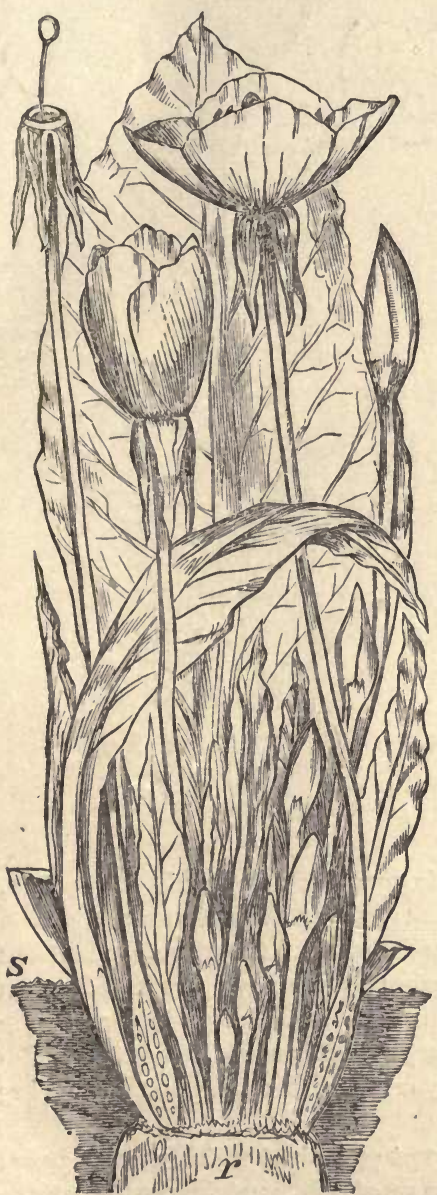

This picture represents part of a plant whose yellow flowers are among the first to greet the new year. It is shown as it would appear if cut down through the center after removing most of the outer leaves. The leaves and flowers all grow from the flat summit of a thick root-stock. It will be noticed that the buds are younger as the center is approached. Possibly you have tried to analyze one of these flowers. If so, you probably got on nicely till you tried to find the ovary. I hope you kept searching and at last felt the satisfaction which rewards the discoverer. However, you can determine the name, and thus have the book tell you where the ovary is. The poorest eyes can see that the leaves are all radical; that the four divisions of the calyx are reflexed; that four broad petals and eight stamens grow upon it; and that there is one pistil whose slender style bears a globose stigma. You can not doubt that the plant is to be sought under B., in Division 1, but you are unable to say whether the ovary is superior or not. In such a case, search first for the order under the head "Ovary SUPERIor;" and, if not satisfiel there, try the head "Ovary and Frutt Inferior." Since there is but one pistil, you look under " ** $\mathrm{Pis}$ til only one." The plant is not a shrub, so you next stop at "†+Herbs." The first division under this is the only one admissible, because the leaves are all radical. But in no case under this head is the nun:ber of stamens eight. We therefore try the subhead "2. Ovary and Fruit Inferior," etc. It is evident that the descriptive line, "Parts of the flower. mostly in 4's," etc., is the only one that fits our plant, so we turn to p. 59, where we find nothing in the description of the order Onagraceæ to rule our plant out. The lines descriptive of the genera are all unsuited to our plant, except one, which refers us to the genus CEnotliera, the de. 


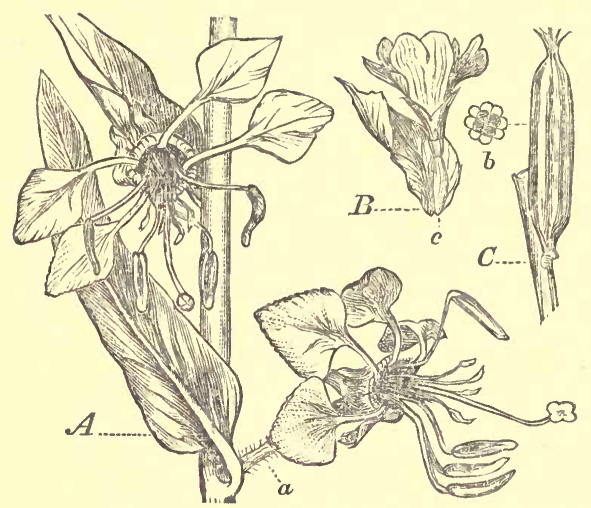

Fig. A. Clarkia elegans; $a$, in-

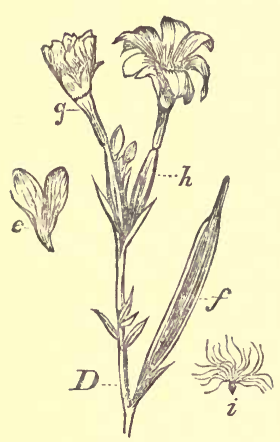
ferior, scssile ovary of the axillary flower. Fig. B. Boisduvalia densiflora; $c$, inferior ovary, sessile in the axil of a bret. Fig. C. Capsule of Godetia; $b$, cross section of the same. Fig. D. Epilobium paniculatum; $h$, inferior ovary; $f$, a grown capsule; $g$, tube of calyx above the ovary; $e$, one of the bifid petals; $i$, one of the seeds bearing a tuft of silken hairs.

The figure on the right represents Cardamine paucisecta, a pod of which is represented at $e$ cn the opposite page.

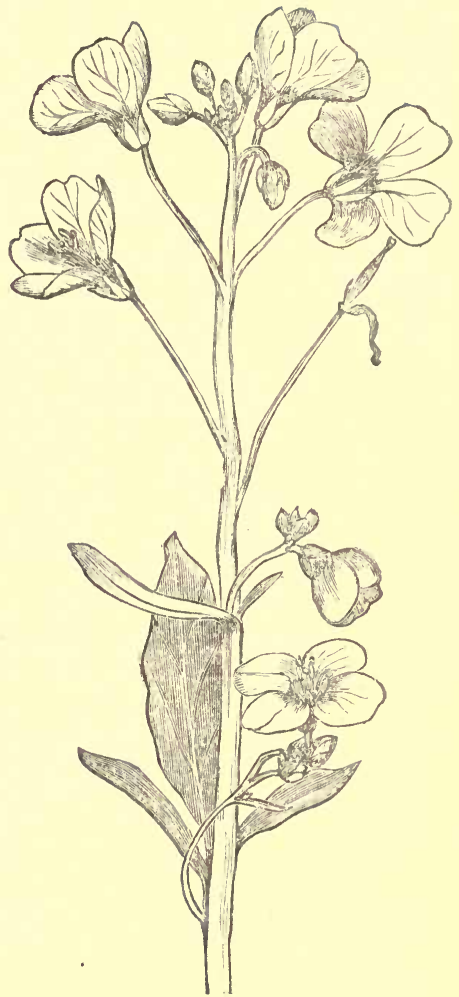

scription of which (p. 60) is satisfactory. Our plant is acaulescent or stemless; therefore, according to the book, the calyx tube is filiform (slender) above the underground ovary. This being verified by examination, there can be little doubt that the plant is Enother $a$ ovata. You now see that the flowers, instead of growing upon scapes, are sessile upon the end of a root-stock. The apparent flower stem is the slender calyx tube and style consolidated. When you plucked the flower, the ovary was left under the ground. No wonder you could not find it. Later in the season you will find other plants belonging to this order; then the figures above will help you.

The figure at the right above represents the upper part of a plant which usually grows in moist places. The white flowers have four separate sepals; four petals; six stamens in two sets, two being shorter and otherwise different from the other four, and one pistil. 
These characters lead you in the key to the o der Cruciferæ, but it is not easy to decide farther, because you have not the fruit. Look for the pods a few weeks later, and you

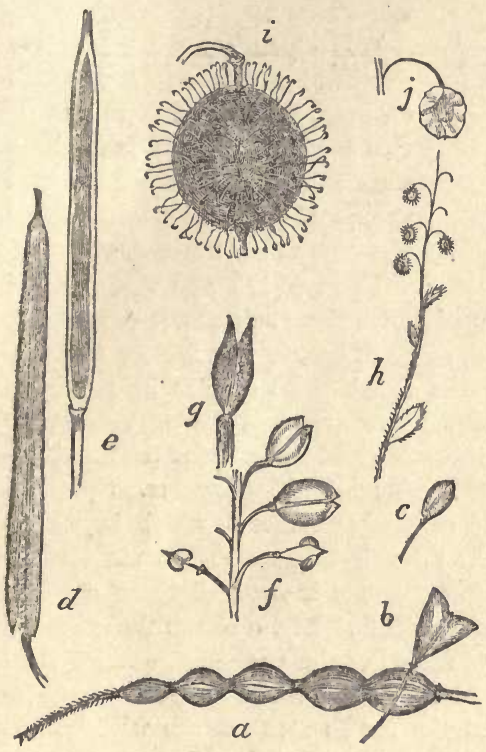
will find them long and flat; as represented in the figure at $e$ on the left. You can then determine the name of the plant. The seed poils here figured will help you in determining some of the plants in this order.

The curious flower depicted below is another early bloomer. You must cut the flower open and study it carefully. The four-sometimes five-petals are joined together, and bear upon the short tube the four stamens which hug the pistil tightly and form a beak like that of a bird. The ovary does not adhere to the calyx, and if a seed pod is partly grown, it will be easy to see that the seeds grow upon a central placenta. Turning to the key you are called upon to de. cide whether the stamens are opposite the lobes of the corolla or not. They certainly are opposite, so the order Primulaceæ is evidently where our plant belongs. The pretty little foreigner Anagallis is here figured, and it will be

TPPER FIG. $-a$, indehiscent pod of Raphanus Raphanistrum; $b$, pod (silicle) of Capsella Bursa-pastoris; $c$, pod o" Capsella divaricata; $d$, pod (silique) of Tropidocarpum, flattened contrary to the partition; $e$, pod of Cardamine paucisecta, flattened parallel with the partition (septum); $f$, two pods (silicle) of Lepidium nitidum, and two partitions from which the valves have fallen, showing that there was one seed in each cell; $g$, pod of Lepialum latipes, showing the broad pedicel whlch suggested the speclfic name; $h$, a branch of Thysanocarpus pusillus, with four of 1ts 1-seeded pods; $i$, one of the pods magnifiel to show the hooked hairs; $j$, pod of Thysanocarpus curvipes.

Lower Fra.-c, reflexed petals of Dodecatheon Meadia; $f$, flaments; $a$, anthers; $s$, stioma (not always protrucing); $i$, involucre; $p$, s:ape (radical peduncle). The horizontal figure represents a rather small branch of Anagallis arveusis.

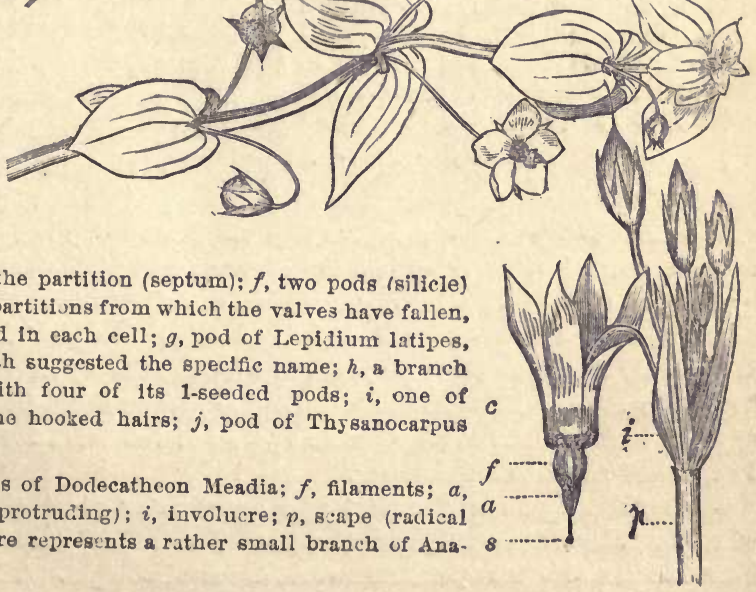




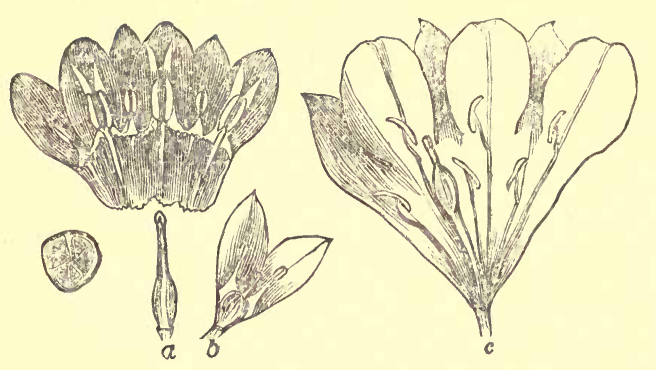

well to real the desceinsica of Trientalis, that you may lnow it when found.

When you get a head of the purple-blue flower: of Brodicer capitata, figured on page xxiv of this book, it will be the proper time to study the figures on t'is page, and what is here said about the genus they illustrate.

Upon p. 113 you will find the

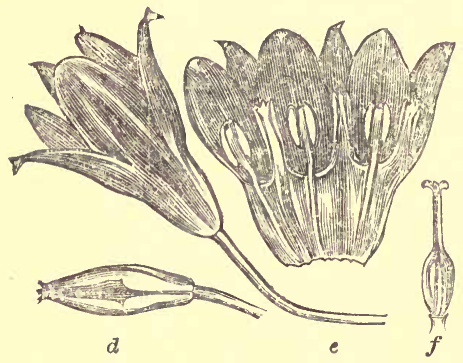

a. Perianth of Brodirea capitata laid op n, with pi-til and section of mature capsule. $b$. Two segments of the perianth of.B. lactea and the pistil. c. Perianth and 1)istll of B. laxa. $d$. Lud and flower of B. to restris. e. Same with perianth laid open. $f$. The pistil.

species grouped under three sub-genera or sections. Figures $a, d$, and $e$ illustrate the first, $c$ the second, and $b$ the third. The species belonging to the first section are arranged uncler two hearls marked by asterisks, and those under the first heal are under subheads marked by daggers. Species 4 and 5 elosely resemble number 6 , which is put under a differnt head, becanse it has six true or anther-bearing stamens insteal of three stamens and three staminodia. Fig. $a$ shows that three of the filaments came near being antherless. Petaloi: staminodia replace these small stamens in species 4 and 5 , and the fertile stamens are without the winglike appendages shown in Fig. a. Observe that the staminorlia in one of these species are cleft. The first three speeies have flowers resembling the one shown in Figs. $d$ and $e$, in which the staminodia (opposite the outer segments of the perianth) are not petaloid, but resemble true stamens. Observe that the first species is distinguished by staminodia not notched at the top as shown in the figure. The speeies in $\S$ Seubertia resemble the first t'iree in general appearance, but the stamens and pistils are very difierent, as is shown by Fig. $c$. Observe that the stamens have versatile instearl of basifixed anthers; and the orary is upon a stipe, instead of being sessile. Douglas' Brodixa, of Oregon, is lite Fig. $c$, only the base of the perianth is broader, the upper row of stamens have broact bases, the stipe is shorter and the flowers are on short pedicels, so as to form a subcapitate umbel. The most common species of the third section is the White Brodixa. Fig. $b$ shows a part of the flower.

The middle figure on the next page represents a plant, the curious eup-like leaves of which must have attraeted your attention. The leaf eups are frequently mueh larger than here shown, and borne upon stems a foot or more in height. Though the flowers are small, 

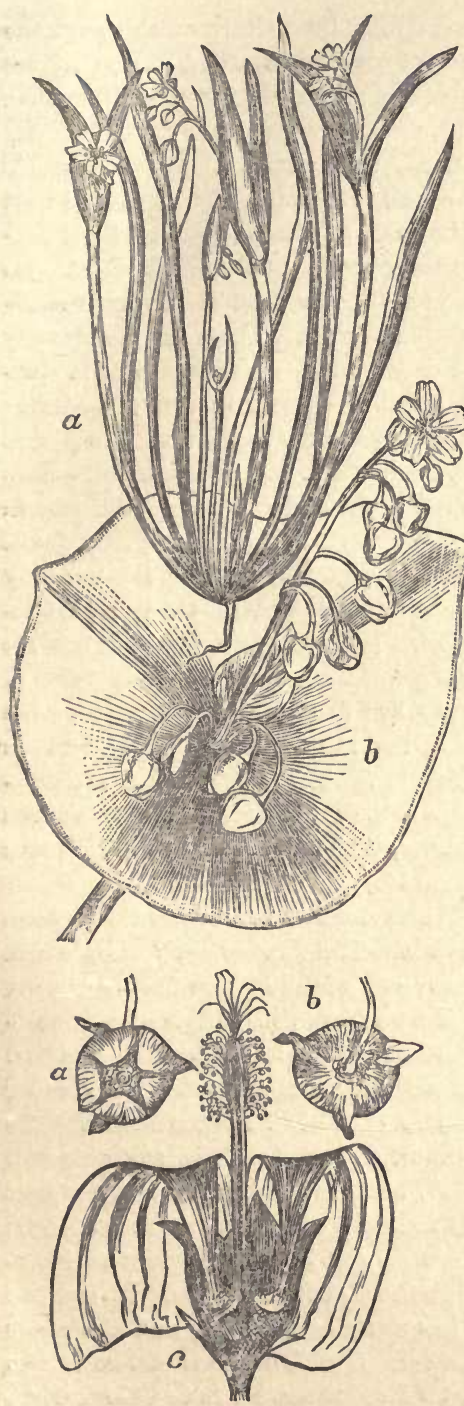

you readily decide that the sepals are two, and t'iat there are five petals and five stamens. The seed pods show that there is but one pistil, and that the calyx does not adhere to the ovary; that is, the ovary is superior. Armed with this information, you turn to the key where you search under "B. Stamens 10 or less." Evidently the correct subheads are: "1. Ovary, or ovaries, superior," etc.; “* * Pistil only one;" “+† IIerb;" “ + Leaves mostly rarlical;" " Stamens 5 , opposite the petals; sepals 2; style 3-cleft-Portulacaceæ, 20." Turning to p. 29 you find that Claytonia is the only genus having 5 stamens, and that this plant must be Claytonia perfoliata.

The little plant figured above $(a)$ evidently answers to the description of the Var. exigua, which is now considered by the best authority to be a distinct species. The stem leaves are sometimes broad and united at the base. The radical leaves are nearly terete, as shown in the figure. This species is most obviously distinguished from the two varieties of the Cup-leaved Claytonia, by its glaucous leaves. The plants are often smaller than here represented, and rarely much larger.

Kellogg's Lavatera, or Tree Mallows, an everblooming shrub, common in cultivation, is a constant source of material with which to illustrate the Mallows Family. The figure at the bottom of the page represents one of the flowers cut ihrough the center, so as to show the structure. The fruit of a very common weed of the same family is also shown. The most common native plant is Sidalced humilis, described on page 32 . Hollyhock, cotton, okra and Abutilon are foreign plants of this order, common in cultivation. The latter is a shrub with drooping flowers; the petals incurved, and the stamens sticking out (exserted).

Cpper T IG.-a. Claytonia exigua (entire plant). b. Claytonia perfoliata.

Lower TrG.- $a$. Fruit of Malva rotundifolia. $b$. Same, slowing the bracts of the persistent calyx. c. Kollogg's Lavatera. (L. assurgentiflora.) 


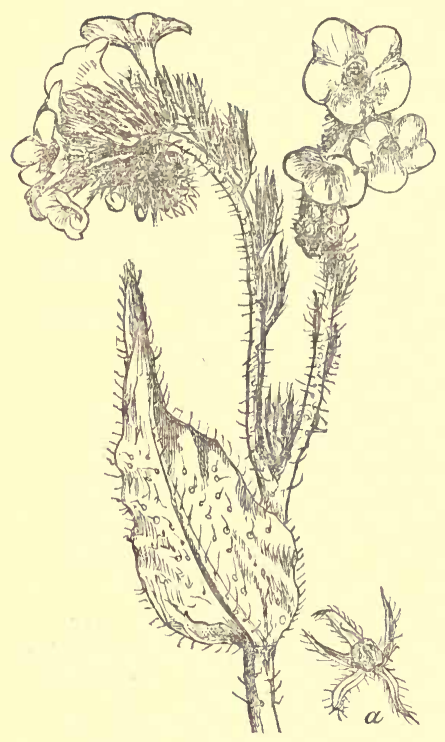

Amsinckia lycopsoides. a. Calyx spread apart to show the ripe alienes.

You may recognize in the picture on this page the likeness of one of our most troullesome native weeds. The yellow flowers are often smaller than here represented, and the upper leaves are generally narrower. Indeed, this plant, along with many others of this coast, is prorokingly variable in its appearance. Pull off a corolla, and a single undivided style is uncorered. Follow this down into the calyx, and you discover that it grows from between four seed-like ovaries. These are more easily seen in an older calyx, as shown at $a$. Now it happens that this peenliar compound ovary, together with the coiled inflorescence, belongs only to plants of the order Borraginaces. A coiled inflorescence and a pistil with a divided style is found only in plants of the order Hydrophyllaceæ. Any plant with a four-parted ovary and regular flowers may be sought under the former orler. Creeping Heliotrope or Blue Weed (IIeliotropinm Curassicticum) is a Borraginaceous plant with oraries merely 4-lobel. The Mint Family has fruit similar to that of the Borrages (see $d$ and $e$ in the figure on p. 11), but the flowers are irregular. The Verbenas are distinguished from the Mints by nearly regular flowers and a 4-lobel orary, which does not split into parts until quite ripe. (See $a$ in the left-hand figure on page 11.)

The plant figured at the top of the opposite page is common in open woorls throughout the Coast Ranges and the foot-hills of the Sierra Nevada. The fluwers are white, tingert with purple. Each of the three incurved petals is covered with hairs on the immer sicle, and is marked near the base by a depression which is seen upon the outside as a projecting boss. This is called a gland, and is one of the characteristic marks of the genus. Since the three-cornered ovary is superior, we at once refer the plant to the order Liliaceæ, where we again read the characters given in each of the three series. The stamens in this plant are hypogynous, not perigynous, and the anthers are extrorse. Therefore, Series I is passed. Series III is excluded, because the anthers in this plant are not versatile. Evilently the name is to be sought under SErres II, which is dividerl into three sections. You now see why you should have dug up one of the plants. How ever, you can decide the genus without knowing that the plant is bulbous. It can not belong to $\$ 3$, since one of the two genera under it has umbellate flowers, and the other solitary flowers. In $\S 2$, the perianth segments are similar. Our plant then must be sought in $\$ 1$, and under the head “** Perianth segments unlike," which leads to Calochortus, 


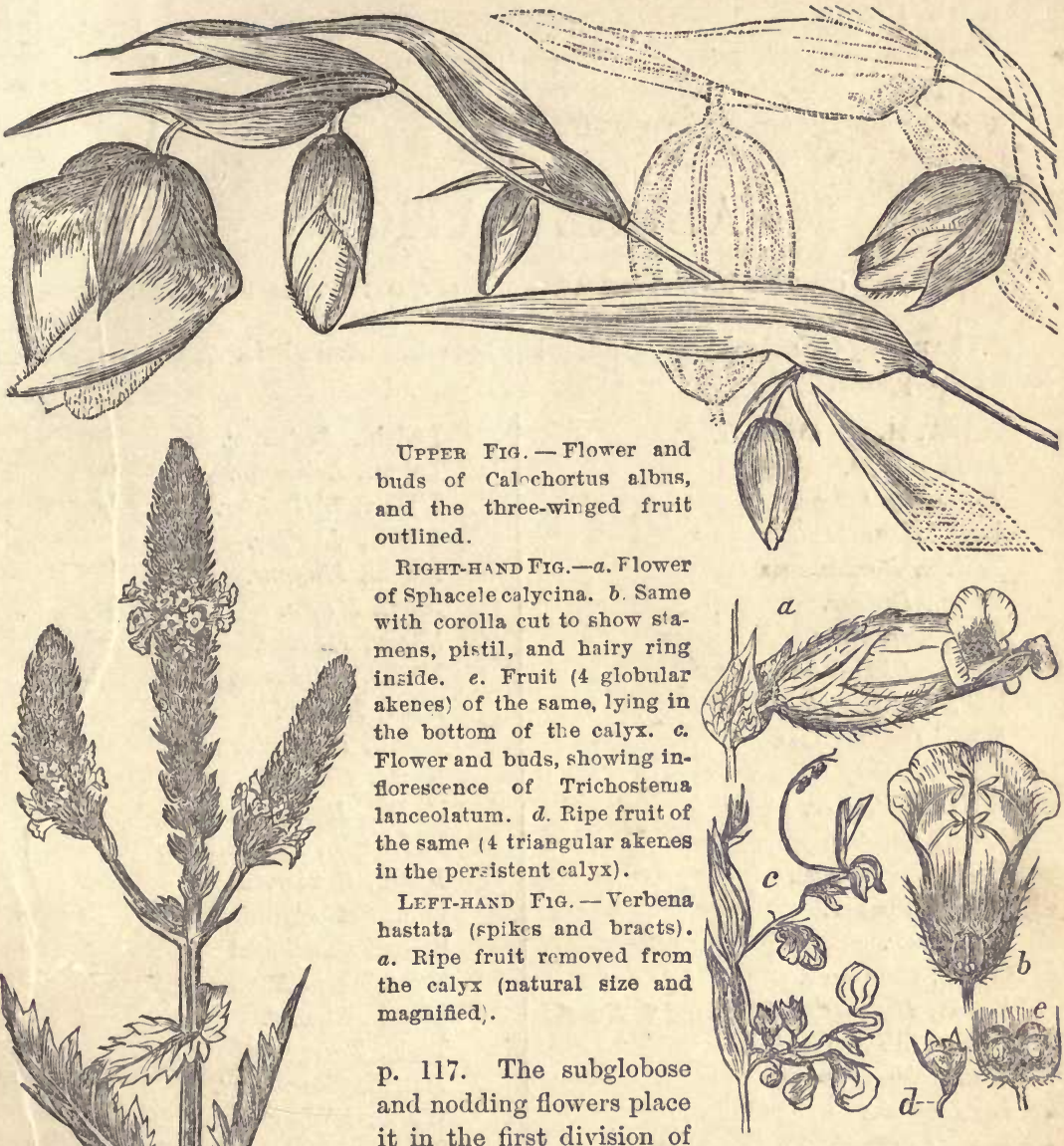
it in the first division of

$\S 1$, Eucalychortus. Our plant is the white species. The yellow species has larger flowers. The stiflly erect, open flowers of $\S 2$ of this genus have a markedly different appearance from the species here figured; yet their structure is similar. The spots upon the petals cause them to resemble the wings of buiterflies; hence the common name Butterfly Tulip, and the section name Mariposa. 


\section{ABBREVIATIONS}

\section{OF THE NAMES OF AUTHORS CITED IN THIS BOOK.}

* * The names (or abbreviations) following botanical names indicate the botanists wbe named the plants.
A.DC., A. De Candolle.
Arn., Arnott.
Asch., Ascherson.
Benth., Bentham.
Borkh., Borlikausen.
Brew., Brewer.
Cav., Cavanilles.
Cham., Chamisso.
DC., De Candolle.
Desf., Desfontaines.
Dougl., Douglas.
Endl., Endlicher.
Engl., Engelmann.
Esch., Eschscholtz.
Fisch., Fischer.
Gr., Gray.
Grise., Grisebach.
HBK., Humboldt, Bonpland \& Kunth.
Hook., W. J. Hooker.
Horn., Hornemann.
L., Linnœus.
Lag., Lagasca.
Ledeb., Ledebour.
Lehm., Lehmann.
L'Her., L'Heritier.
Lindl., Lindley.
Magn., Magnus.
Mey., Meyer.
Menz., Menzies.
Michx., Michaux.
Moc., Mocino.
Muhl., Muhlenberg.
Nutt., Nuttall.
R. Br., Robert Brown.
Reichenb., Reichenbach.
Rœm., Rœmer.
Sch., Schlechtendal.
Schw., Schweinitz.
Scop., Scopoli.
Steud., Steudel.
Torr., Torrey.
Tourn., Tournefort.
Walp., Walpers.
Willd., Willdenow. 


\section{ANALYTICAL KEY.}

The calyx and corolla together of either more or less than six parts*....... CIASS I The calyx and corolla together of 6 parts:

Stamens 6 or less..........................................

Stamens $9 ; \ldots \ldots \ldots \ldots \ldots \ldots \ldots \ldots$ Umbellularia, p. 106, or Eriogonum, 105

Stamens 10; united sepals $5 . \ldots \ldots \ldots \ldots \ldots \ldots \ldots \ldots \ldots \ldots . . \ldots$ Leguminosæ, 38

Stamens many; caducous sepals $2 \ldots \ldots \ldots \ldots \ldots \ldots \ldots \ldots \ldots$. Fapaveraceæ, 20

Stamens many; sepals $3 \ldots \ldots \ldots \ldots \ldots \ldots \ldots \ldots \ldots \ldots \ldots \ldots \ldots$. Sagittaria, 122

\section{CLASS I.-EXOGENS OR DICOTYLEDONS.}

Calyx and corolla both present.

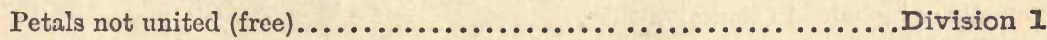

Petals more or less united (cohering)....................... Division 2

Corolla wanting; calyx often petaloid, sometimes wanting............ Division 3

\section{DIVISION I.-POLYPETAL永.}

A. Stamens more than 10 and more than double the number of petals.

1. IIYPOGYNOUS, $i$. e., on the receptacle (not adhering to the sepals or petals).

* Pistils few to many, distinct carpels, rarely one.

Calyx deciduous, sepals $5 . \ldots \ldots \ldots \ldots \ldots \ldots \ldots \ldots \ldots \ldots$. Ranunculacer, 16 Calyx caducous, sepals 2 or $3 \ldots \ldots \ldots \ldots \ldots \ldots \ldots \ldots . \ldots . \ldots . \ldots$. . . . . . 20

Calyx persistent, sepals 3 or 4 ; aquatic plants............... Nymphæaceæ, 20

Calyx persistent; leaves all radical.........................Rosacez, 49

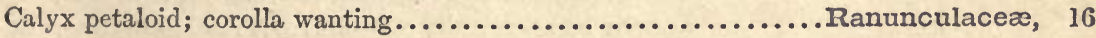

* * Pistil one and compound, as shown by two or more stigmas, or more than one cell in the

Petals more numerous than the sepals. ovary.

Indefinitely numerous, slender, persistent; aquatic plants..... Nymplaæaceæ, 20 Just twice as many (4-6); sepals caducous.................Papaveraceæ, 20

Five to sixteen; sepals persistent; fleshy herbs ............Portulacaceæ, 29

* Maianthemum (see p. 115) has a 4-parted perianth; 4 stamens and 2 or 3 parallel veined leavis. 
Petals of the same number (5) as the persistent sepals, yellow.

Leaves opposite; sepals equal........................Hypericaceæ, 30

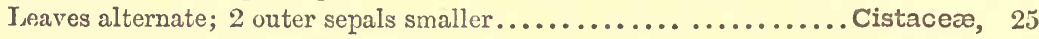

2. PERIGYNOUS or EPIGYNOUS (on the frce or adnate calyx).

Leaves opposite, simple; fleshy herbs..................... Ficoideæ, 63

Shrubs. Sepals and petals numerous.......................................... 55

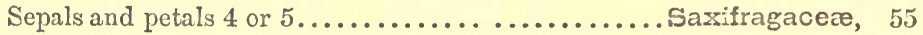

Leaves alternate, with stipules.................................... 49

Without stipules; rough herbs.................Loasacea, 62

\section{ON THE CLAWS OF THE PETALS.}

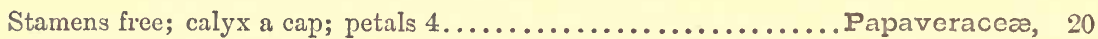

Stamens many united to form a tube; petals $5 . . . \ldots \ldots \ldots \ldots . . . .$. Malvaceæ, 31

Stamens 10 to 16 united for half the length; petals $5-8 \ldots \ldots$...... Styracaceæ, 20

\section{B3. Stamens 10 or less.}

1. OVARY or OVARIES SUPERIOR (free from the calyx), or mainly so, but sometimes included in the calyx-tube.

\section{* Pistils more than one and distinct (not united).}

Pistils of the same number, as petals and the sepals.

Leaves simple entire, fleshy.........................................

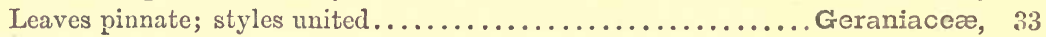

Pistils not corresponding in number with the petals and sepals.

Two, united at the base. Trees with compound leaves ........ Sapindaceæ, 37

Herbs with simple leaves.......... Saxifragaceæ, 55

Many. Stamens on the receptacle................. Ranunculaceæ, 16

Stamens on the calyx................................ 49

Style and stigma one.

\section{* Pistil only one.}

+ Shrubs or trees.

Sepals, petals, and stamens 6 each, in 3's opposite each other..Berberidaccæ, 19

4 to 5 each; leaves 3 -foliolate, alternate..Rutaceæ, 34

5 each; leaves simple, opposite...... Celastracer, 35

Calyx 2-lipped; petals unequal; stamens 5-S, exserted.......... Sapindaceæ, 37

Calyx 4-toothed; petals 2 ; stamens $2-4$; fruit a samara.......... Oleaceæ, 73

Styles or stigmas more than one.

Styles 2; leaves opposite; fruit 2-winged................ Sapindaceæ, 37

Style 3-cleft; stamens 5, opposite the small petals............Rhamuaceæ, 35

Stigmas 3; leaves alternate 3 -foliolate................. Anacardiaceæ, 38

Stigma 5-lobed; a small shrub with opposite or whorled leaves..... Ericaceæ, 68 


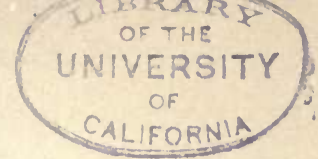

++ Herbs.

\section{‡Leaves mostly radical.}

Stamens 5, anthers united; lower petal spurred; style $1 . \ldots . . . . .$. Violacea, 25

Stamens 5, opposite the pctals. Sepals 2; style 3-eleft...........Portulacaceæ, 29

Sepals united; styles 5.........Plumbaginaceæ, 71

Stamens 10, on the receptacle; stigma 5-lobed................... Ericaceæ, 68

Stamens 10, on the calyx; styles $2 . \ldots \ldots \ldots \ldots \ldots \ldots \ldots \ldots$. Saxifragacer, 55

Stamens 6 , in 3's; sepals 2 ; petals 4 , in pairs................. Fumariaceæ.

Corolla regular.

\section{$\ddagger \ddagger$ Leaves alternate.}

Stigma one, often 2-lobed; stamens 6 (2 and 4)............... Cruciferæ, 22

Stigma 1, calyx a striated tube bearing 6 petals............. Lythraceæ, 59

Stigmas 5; sepals and petals 5 each; stamens $5-10 \ldots \ldots \ldots \ldots .$. Geraniacer, 33

Styles $3-5$; sepals and petals 5 each; stamens $5 \ldots \ldots \ldots \ldots \ldots \ldots$. Linaceæ, 32

Style 3 -cleft; sepals 2 ; petals 5 ; fleshy herbs..............Portulacaceæ, 29 Corolla irregular; style one.

Stamens 10; fruit a legume......................... Leguminosæ, $3 S$

Stamens 5; anthers united; lower petal spurred..............Violaceæ, 25

Stamens 6, in 2 sets; stigma 2-lobed.................... Fumariaceæ, 22

Stamens $6-8$, united; ovary 2 -celled.................... Polygalacea, 27

\section{$\ddagger \ddagger \ddagger$ Leaves opposite or whorled.}

Styles 2-5; fruit a 1-celled capsule; stamens 10 or 5.......... Caryophyllaceæ, Styles 3 ; flowers sessile; stamens 4 to $7 \ldots \ldots \ldots \ldots \ldots \ldots \ldots \ldots$. . . . . . . . .

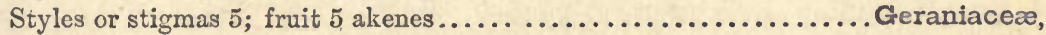
Small white flowers clustcred on terminal peduncles ............ Sazifragaceæ, Leaves in 3 's; white flowers; petals 6 in 2 sets................Papaveraceæ, Leaves a single pair on the stems; fleshy..................Portulacaceæ,

2. OVARY AND FRUIT INFERIOR (adherent to the calyx), or mainly so.

Shrubs; sepals, petals, and stamens each 4-5; leaves simple.

Stamens opposite the clawed petals; style 3 cleft...........Rhamnacea, 35

Sepals petaloid; ovary globose; styles 2, or 2-cleft............ Saxifragaceæ, $\left.\begin{array}{l}\text { Leaves opposite; flowers in heads with petaloid involucre or in } \\ \text { eymes; the sepals, petals, and stamens } 4 \text { each............. }\end{array}\right\}$ Cornaceæ, 55

Uerbs. Scpals and petals each 5 ; styles distinct; leaves simple..... Saxifragaceæ, 55 63

Parts of the flower mostly in 4's (rarely in 2's or 6's)........... Onagraceæ, 59

Tendril-bearing vines, with prickly fruit................ Cucurbitaceæ, Flowers in umbels; styles $2 . . \ldots \ldots \ldots \ldots \ldots \ldots \ldots \ldots \ldots$ Umbellifora, 


\section{DIVISION 2. GAMOPETAL无.}

\section{A. Ovary Inferior (adherent to the calyx) or largely so.}

Stamens more numerous than the lobes of the corolla, 8 or 10.

Distinct and free from it, or nearly so.................... Ericacea, 68 Stamens as many as the lobes of the corolla (5, rarely 4$)$, united into a tube.

Flowers in an involucrate head, resembling a single blossom...... Compositze, 66

Flowers separate in racemes or spikes; ovary slender ......... Tobeliaceæ, 67 Stamens as many as the corolla-lobes, distinct.

Nearly or quite free; leaves alternate, no stipules.......... Campanulaceæ, 67

Inserted on the corolla; leaves opposite or whorled.

With stipules, or in whorls, entire ..........................er, 65

Without stipules, opposite. Calyx with minute lobes...Caprifoliaceæ, 64

Prostrate herbs. Abronia in...................Nyctaginaceæ, 104

Stamens only 3, fewer than the lobes of the corolla.

Leaves opposite; stamens distinct; flowers minute ......... Valerianaceæ, $\quad 56$

Leaves alternate; stamens united; fruit prickly........... Cucurbitacea, 63

\section{B. Ovary Superior (free from the calyx) or nearly so.}

1. FLOWERS REGULAR or nearly so.

* Stamens, twice as many as the lobes of the corolla.

Stamens 8-10, distinct; corolla campanulate or ovoid.............. Ericaceæ, 68 Filaments united for half their length; corolla nearly polypetalous.........styrax, 20 Pistils or styles as many as the petals; fleshy herbs............. Crassulaceæ, is

* * Stamens as many as the lobes of the corolla and opposite them.

Styles 5; long-clawed petals, scarcely united............... Flumbaginaceæ, il Style 1; corolla lobes, reflexed or rotate................... Primulaceæ, 72 * * Stamens as many as the lobes of the corolla and alternate with them.

Style and stigma one, leaves entire (lobed in the first).

I.eaves mostly radical; flowers on a scape....... Romanzoffia in Hydrophyllacez, So Leaves all radical; flowers in a spike; 4-lobed corolla scarious.....Plantaginacea, 103 Leaves alternate; flowers mostly in coiled spikes; ovary 4-lobed....Borraginaceæ, 83 Leaves alternate; flowers rotate to funnelform; ovary 2 -celled.........Solanaceæ, SS Leaves opposite; flowers in cymes; ovaries $2 \ldots \ldots \ldots \ldots \ldots . .$. Apocynacea, 73 Leaves opposite or whorled; flowers in umbels; ovaries $2 \ldots .$. . Asclepiadacer, 73 Style 1 or none, stigmas 2.

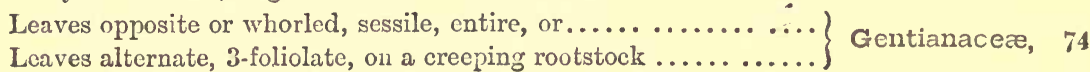


Leares alternate; twining vines; flower's funnelform, axillary..... Convolvulaceæ, 86 Leaves alternate; flowers not axillary ................. Hydrophyllaceæ, 80 Leaves alternate; flowers in a head, with acerose bracts............ Gilia, § 5 , is

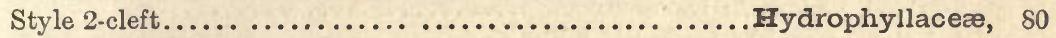

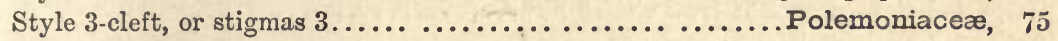

Style 2; leaves simple or none.

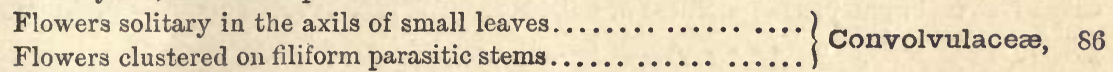
Flowers in naked cymose clusters; shrubs...............Fydrophyllaceæ, 80

* * * Stamens fewer than the lobes of the slightly irregular corolla.

Limosella or Veronica in........................... Scrophulariaceæ, 93

2. FLOWERS IRREGULAR. Stamens with anthers 4 in pairs or 2; style 1; leaves opposite or none, except in some of tie Scrophulariaceæ.

Ovary l-celled; corolla curved; leafless root parasites........... Orobanchaceæ, 96

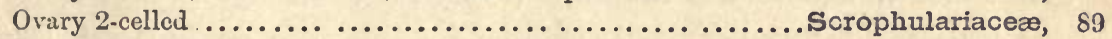
Ovary 4 parted, forming in fruit 4 seedlike nutlets................ Labiatæ, 97 Ovary 4-lobed; fruit splitting into 4 nutlets..................Verbenaceæ, 102

\section{DIVISION 3. APETALEE.}

\section{A. Ovary inferior (calyx adherent) or apparently so.}

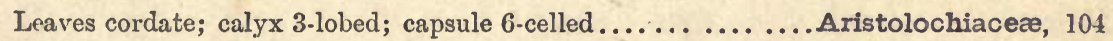
Leaves opposite; calyx salver-furm; ovary 1 -seeded............Nyctaginaceæ, 104 Leaves opposite; calyx inconspicuous; corolla tubular........... Caprifoliaceæ, 64

\section{B. Ovary superior (free from the calyx). \\ * Herbs; leaves alternate.}

Petaloid calyx withering-persistent; akene 3 -cornered or flat........Polygonacea, 105 Petaloid sepals deciduous; carpels several.................Ranunculaceæ, 16 Sepals 4, green, deciduous; small pods 2-celled........................... 22 Flowers asepalous in a spike, with a petaloid involucre............. Anemopsis, 106 * Herbs; leaves opposite, entire.

Capsule 1-celled; style and stigma 1; leaves fleshy.

Stems prostrate; flowers in involucrate heads............. Nyctaginaceæ, 104

Stems erect; flowers axillary.................... Glaux in Primulaceæ, 73 Capsule 1-celled; style or stigmas, 3 or more................Caryophyllaceæ, 27 Capsule $3-5$-celled; flowers axillary. ...............Mollugo in Ficoideæ, 63 
*** Shrubs or trees; leaves alternate, entire (except in the last).

Calyx tubular, bearing the stamens; akene tailed................. Rosaceæ, 49 Calyx 6-parted, yellowish; leaves aromatic..................... Lauraceæ, 106

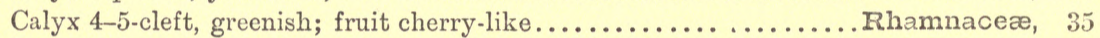
Calyx 3-4-cleft, yellowish; stamens $6-8 \ldots \ldots \ldots \ldots \ldots \ldots \ldots . \ldots . \ldots . \ldots . \ldots$ Thymelaceæ, 107 Calyx 5-cleft, bright yellow; stamens 5, united................ Sterculiaceæ, 20

* * * Trees; leaves opposite, pinnate.

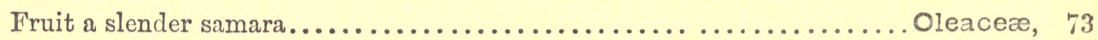

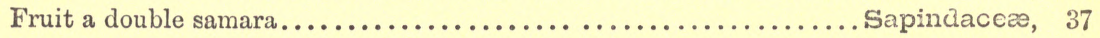
*****A half-woody climber; leaves opposite.-Clematis, 16.

\section{CLASS II.-ENDOGENS OR MONOCOTYLEDONS.}

A. Perianth adherent to the ovary (ovary inferior).

Flowers irregular. Anthers 1 or 2 on the pistil.................. Orchidaceze, 108 Flowers regular. Stamens 3 , anthers extrorse.................. Iridaceæ. 110

B. Perianth free (ovary superior).

Flowers in whorls. Carpels 8 to many.........................smacez, 108 Pistil 3-celled; stamens 3 to $6 \ldots \ldots \ldots \ldots \ldots \ldots \ldots \ldots \ldots \ldots$ Liliaceæ, 110 Flowers greenish in a spikø................... Triglochin in Alismacea, 108

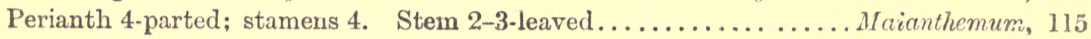
Pistil 2-celled; red flowers in an umbel..................... Clintonic, 119 


\section{BOTANY}

OF

\section{WEST-CENTRAL CALIFORNIA.}

\section{SERIES I.}

\section{FLOWERING OR PHANOGAMOUS PLANTS.}

Plants producing flowers and seeds; the former consisting, at least, of stamens and pistils, which may be together in the same flower, or they may separately form staminate and pistillate flowers growing on the same individual, or different individuals of one species; the latter containing a germ, or embryo.

\section{Class I. - Exogens or Dicotrledons.}

Stems consisting of pith in the center, bark on the outside, and between these, fibrous or woody tissue, which, in perennial stems, increases from year to year by the addition of layers on the outside next the bark. Embryo usually of two opposite cotyledons, or rarely with several in a whorl.

\section{SUb-Class 1. - Avgiosperus.}

Pistil consisting of a closed ovary which forms the fruit. Cotyledons two. 


\section{DIVISION I. POLYPETAL无.}

\section{Order 1. RANUNCUIACEZE.}

Herbs or shrubs, with colorless juice; foliage various; stipules none; organs of the flower free and distinct; sepals, petals, and pistils few or many; stamens numerous; petals sometimes wanting, then the sepals are usually petaloid; anthers short and adnate; seeis with minute embryos in fleshy albumen.

\section{* Flowers regular.}

Petals none; shrubby climbers................................ematis. I Petals none; small herbs. .................................nemere. 2 Petals 5 or more; carpels numerous.......................Ranunculus. 3 Petals 5, spurred; carpels $5 . \ldots \ldots \ldots \ldots \ldots \ldots \ldots \ldots \ldots \ldots \ldots$ Aquilegia. 4 Upper sepal spurred................................... Delphinium. 5 Upper sepal hooded.....................................conitum. 6 * * * Sepals large, leaf-like, persistent.

Flowers large......................................... Pæonia.

\section{CLEMATIS, L. Virgin's Bower.}

Sepals 4, colored and petal-like, valvate in the bud. Pistils numerous; styles persistent, becoming long feathery tails in fruit. Ilalf-woody climbers or perennial herbs, with opposite leaves.

1. C. ligusticifolia, Nutt. Stems climbing by the petioles of the 5-foliolate leaves; leaflets broadly ovate to lanceolate, $1 \frac{1}{2}$ to 3 inches long, acute or acuminate, 3-lobed and coarsely toothed, rarely entire or 3-parted. Flowers diœcious, paniculate; sepals thin, silky, white, 4 to 6 lines long; akenes pubescent; tails 1 to 2 inches long.

Var. Californica, Watson. Leaves silky-tomentose bencath, often small.

2. C. Iasiantha, Nutt. Leaves 3 -foliolate; leaflets ovate, 1 to $1 \frac{1}{2}$ inches long, acute, coarsely toothed or 3-lobed or the terminal 3-parted. Flowers solitary on 1-2-bracted peduncles; sepals obtuse, thick, 6 to 10 lines long.

\section{ANEMONE, L.}

Sepals 4 to 20, colored and petal-like, imbrieated in the bud. Petals none. Pistils numerous; style short; stigma lateral; akenes compressed, pointer, in a head. Ereet perennial herbs, with lobed or divided leaves, which are radical, except those which form an involuere below the flower. 
1. A. nemorosa, L. (Wood ANEmone.) Smooth or somewhat villous; stems from a slender rootstnck, 3 to 12 inches high, without radical leaves, one-flowered; involucre of 3 petioled ternate leaves, the divisions cuneate-oblong to ovate, incisely toothed or lobed, or the lateral ones 2-parted, about an inch long; the 4 to 7 sepals pinkish or white; akenes 12 to 20, oblong, with a hooked beak.

Here belongs Thalictrum Fendleri, Englm. A smooth apetalous diœcious herb; also, Myosurus minimus, L. A very small herb, with a tuft of linear or spatulate entire radical leaves, and solitary flowers on simplo scapes; called Mouse-tail, from its long, narrow receptacle, densely covered with small akenes.

\section{RANUNCULUS, L. BUTTERCUP.}

Sepals usually 5. Petals 3 to 18 . Pistils numerous. Akenes in a head, usually flattened, beaked with the persistent style.

\$1. Aquatic herbs; petals white, with a pit at the base, the claw yellow; akenes transversely wrinkled.

1. R. hederaceus, L., var. Glabrous; stems 6 to 12 inches long, floating; leaves commonly all floating, 3 to 8 lines wide, deeply 3 -lobed, truncate or cordate at the base; the lobes equal, oval or oblong, the lateral ones usually with a broad notch in the apex; submersed leaves none or rudimentary and resembling adventitious roots; peduncles opposite the upper leaves, thicker than the petiole, 6 to 8 lines long; sepals a line long; petals 2 lines long, obovate oblong; stamens 5 to 9 ; akenes 4 to 6 .

2. R. aquatilis, L., var. tricophyllus, Chaix. Stems long, filiform; leaves all submersed and cut into numerous capillary segments, which are 4 to 10 lines long; flowers 3 to 5 lines in diameter; akenes numerous in a globular head.

\$2. Terrestrial herbs, but often growing in wet places; sepals green; petals yellow, with $a$ scale at the base; akenes neither wrinkled nor hispid.

\section{* All the leaves undivided, the margins entire.}

3. R. Flammula, L., var. reptans, Gr. Glabrous throughout; stems filiform, creeping and rooting at the joints, 4 to 10 inches long; leavcs mostly lanceolate and acnte at cach end, entire; flowers 2 to 5 lines in diameter; petals broadly obovate, one half longer than the sepals; akenes few, in a small globular head, plump, smooth; beak very short and curved.

4. R. alismæfolius, Geyer. Similar to the last species, but with stoutish, erect stems, longer flowers and obtuse leaves; akenes straight-beaked.

* * Some or all the leaves ternately compound.

5. R. Californicus, Benth. More or less hairy; stems erect, or nearly so, 12 to 18 inches high; radical leaves, commonly pinnately ternate, the leaves laciniately cut into 3 to 7 parts, which are usually linear; flowers bright yellow, 5 to 10 lines in diameter; 
petals 10 to 14, narrowly obovate; sepals shorter than the petals, refiexed; akenes ncarly 2 lines long, flat, with sharp edges; beak short and curved; heads compact, ovate or globular.

This is by far the most common species, and usually the only one collected by beginners. It varies greatly. The leaves are sometimes simply three lobed and sometimes much cut up. [R. Bloomeri, Wat., belongs here. See p. 122.]

6. I. macranthus, Scheele. Stems stout, 2 to $5 \mathrm{ft}$. high; flowers 14 to 18 lines in diameter; petals commonly 5 or 6 , broadly obovate, shining yellow.

\section{§3. Akenes rough; otherwise as in § 2.}

7. R. hebecarpus, Hook. \& Arn. Rather slender, more or lcss hairy; flowers minute; petals 5 , not more than a line long; sepals hairy, about equaling the petals.

8. R. muricatus, L. Smooth; flowers 5 or more lines in diameter; akenes large and rough, with recurved beaks. Introduced from Europe.

\section{AQUiLEgIA, Tourn. Columbine.}

Sepals 5, regular, colored and petal-like; petals 5, produced backward (upward) into a long tubular spur; stamens numerous, exserted, the inner ones reduced to thin scales; pistils 5; styles slender. Flowers nodding, showy, terminating the branches.

1. $\Lambda$. truncata, Fisch. \& Mey. Stems 1 to $3 \mathrm{ft}$. high; flowers usually red, tinged with orange or yellow; leaves usually ternately compound, leaflets lobed.

\section{DELPHIIJIUM, Tourn. LARKSPUR.}

Sepals 5, colored and petal-like, very irregular, the upper one prolonged backwards at the base into a long spur, which (in our species) contains spur-like prolongations of the upper pair of petals. Petals 4, small and irregular. Stamens many. Pistils 1 to 5. Erect herbs, with palmately-cleft, lobed, or dissected leaves, and racemose flowers.

1. D. simplex, Dougl. Canescent throughout, with a fine, short, somewhat woolly pubescence, rarely smooth; stem stout and strict, 1 to $3 \mathrm{ft}$. high, leafy; leaves all much dissected with linear obtuse lobes, on stout, erect petioles; racemes usually dense and many-flowered, the pedicels often short and nearly erect; flowers small, blue, varying to nearly white or yellowish; sepals 4 or 5 lines long, about equaling the stout, straight spur; ovaries and capsule pubescent.

2. D. variegatum, Torr. \& Gr. Foliage similar to the last, but the flowers much larger, on longer pedicels, forming a short, open raceme; ovary and capsule pubescent.

3. D. decorum. Fisch. \& May. Lower leaves 5-lobed, sparingly toothed, the upper with narrow divisions. Flowers similar to the last, but the spur is usually longer, and the ovary and capsule smooth.

4. D. Californicum, Torr. \& Gr. Stems stout, 2 to $7 \mathrm{ft}$. high; leaves large, 3 to 
5 cleft, the divisions variously lobed; pedicels and dull bluish flowers denscly veivety pubescent.

D. nudicaule, Torr. \& Gr. Distinguisheả by its red flowers.

\section{ACONITUM, Tourn. MONKSHOOD.}

Sepals 5, colored and petal-like, very irregular; the upper one arched into a hood or helmet, which conceals the spur-like blades of the upper pair of petals. General appearance similar to Delphinium.

1. A. Columbianum, Nutt. Sufficiently characterized by the generic description. Rare.

\section{PZEONIA, L.}

Sepals 5, herbaceous. Petals 5 to 10 . Stamens inserted on a fleshy disk. Pistils 2 to 5. Fruit leathery follicles. Perennial herbs with compound leaves.

1. P. Brownii, Dougl. Leaves thick, 1-2-temately compound, the leaflets ternately and pinnately lobed, glaucous; petals leathery, dull, dark red, about equaling the sepals.

\section{ORDER 2. BERBERIDACEZ⿱中⿰㇀丶㇀}

Shrubs or herbs, with compound alternate exstipulate leaves; flowers remarkable for having the bracts, sepals, petals and stamens before each other, instead of alternating. Low shrubs, with rigid pinnate leaves and small yellow flowers..........Berberis. 1 A fern-like herb, with white flowers..................... vancouveria. 2

\section{BERBERIS, I. BARBERRT.}

Sepals, petals, and stamens 6 each, with 3 or 6 bractlets. Carpel 1, forming a berry. Smooth shrubs, with yellow wood, and yellow flowers in bracteate racemes.

\section{* Leaflets pinnately veined.}

1. B. repens, Lindl. Less than a foot high; leaflets 3 to 7 , ovate, acute, 1 to $2 \frac{1}{2}$ inches long, not shiny above; short racemes terminating the stems.

2. B. Aquifolium, Pursh. 2 to $4 \mathrm{ft}$. high; leaflets 7 or more, the lower pair distant from the stem, $1 \frac{1}{2}$ to 4 inches long, shining above, spiny; racemes chiefly clustered in subterminal axils.

3. B. pinnata, Lag. Like the last species, but the leaves more crowded, and the lower pair of leaflets near the base of the petiole; usually 5 to 7 leaflets.

\section{* Leaflets palmately nerved.}

4. B. nervosa, Pursh. Simplo stems but a few inches high; leaves 1 to $2 \mathrm{ft}$. long, of 11 to 17 leaflets. 


\section{VANCOUVERIA, Morren \& Decaisne.}

Sepals and petals 6 each, reflexed, with 6 to 9 bractlets. Stamens 6 . Carpel 1; the stigma cup-shaped. A slender perennial herb, with radical 2-3-ternately compound leaves, and the open paniculate raceme upon a naked scape.

v. hexandra, Morr. \& Dec. The long petioled leaves rising like the fronds of a fern, leaflets 1 to 2 inches broad, petiolulate, obtusely 3-lobed, the margin thickened; the minute flowers on a scape exceeding the leaves.

\section{ORDER 3. NYIMPHAFACE正.}

Aquatic perennial herbs, with peltate or deeply cordate leaves; solitary axillary perfect flowers on long peduncles. Stamens numerous.

Water-Shield. (Brasenia peltata, Pursh.) May be found in ponds. Its elliptical, peltate, floating leaves (green above and brownish-red beneath) and its jelly-coated stems characterize it quite well enough.

The Yellow Pond-Lily (Nuphar polysepalum, Engl.) is more common.

The Order Sarraceniacez is represented by the remarkable Darlingtonia Californica, or California Pitcher Plant, which grows in cold swamps in the northern part of the State, from Mount Shasta to near the coast.

Frankenia grandifolia grows in saline soils, and may be known by its opposite sessile, obovate, or linear oblanceolate, small leaves, with revolute margins; and by its small, pink flowers. It may bo distinguished from a Silene, which at first it seems to be, by its fewer ( 4 to 7 ) stamens and sessile flowers.

The Order Frankeniaceæ should come next to Caryophyllacece. Fremontia Californica, belonging to the Order Sterculiaceæ, which is allied to the Malvaceæ, is most conveniently described here also. It is a small tree, bearing conspicuous yellow flowers in the axils of usually broadly cordate, lobed leaves. The apetalous flowers are sometimes 2 or 3 inches across.

The Order Capparidaceæ is represented in Santa Barbara County, and southward, by Isomeris arborea, a low shrub, bearing bracteate racemes of yellow flowers, the pistils conspicuous on account of their long stipes. The flowers of this plant are apparently like those of the Cruciferæ, and its proper place is next to that order. Capers are obtained from a cultivated plant of this order.

The Order Styracaceæ is represented by Styrax Californica, a pretty shrub, bearing clusters of nearly rotate white flowers, in which the gamopetalous corolla is cut down to the short tube which is adnate to the tube formed by the stamens: Calyx truncate. 


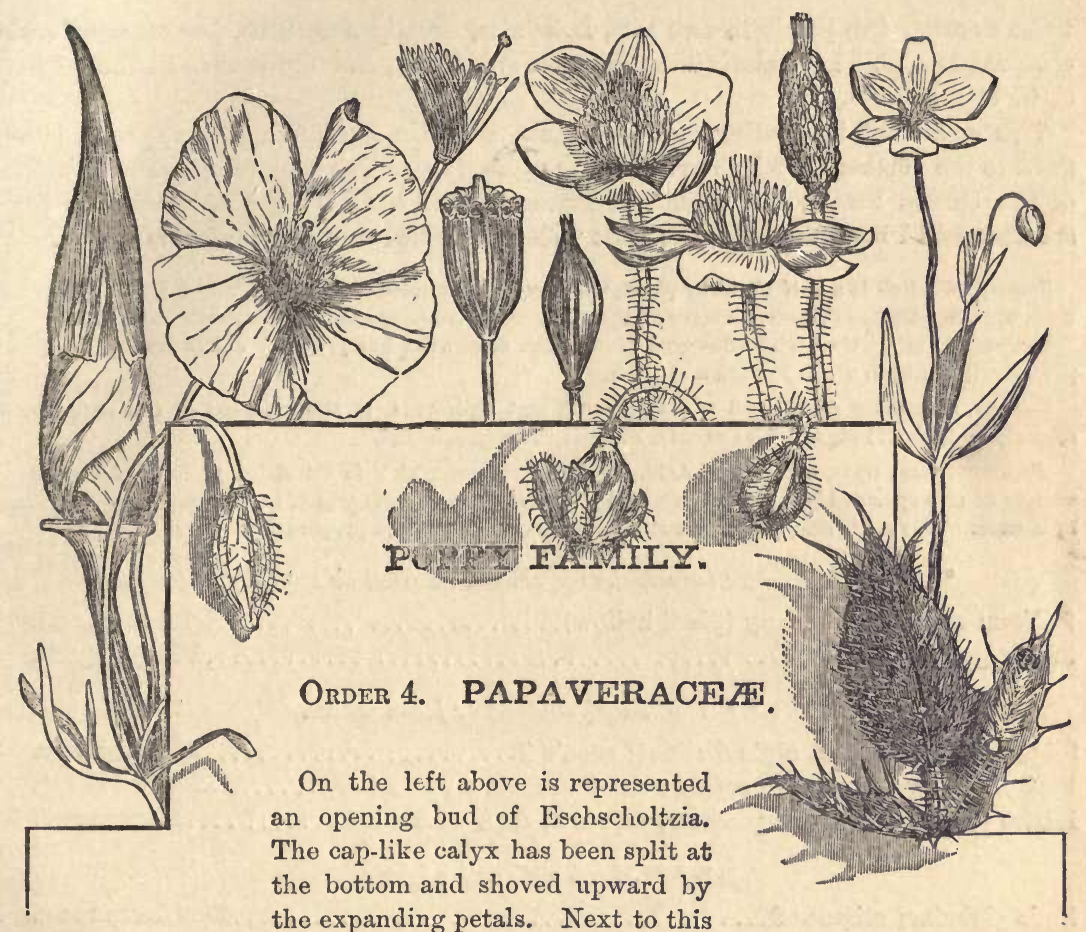

bud is an open flower of Meconopsis and one of its nodding buds. Behind the flower, and projecting above it to the right, is a stem from which the petals have just fallen. The slender filaments bending to one side, as they often do, show the curious pistil which in time becomes the pretty fluted capsule seen below. To the right of the Meconopsis pod is the three-sided capsule of Platystigma lineare. The stem should have a few hairs upon it. The two flowers with hairy stems, the nodding buds below, and the rough seed pod above, belong to Platystemon. Observe the three caducous sepals, just ready to drop from the opening bud. The smooth plant on the right is Platystigma Californicum. If you choose you may call this the Smooth Platystigma, and the other species, with the triangular pod, Hairy Platystigma. The exceedingly prickly Bristly Argemone is represented on the right, below, by a bud and a couple of bracts. A pistil with its white prickles is imperfectly shown against one of the bracts.

The Order Papaveraceæ is characterized by flowers with 2 or 3 caducous sepals, 
twice as many free petals in two sets, indefinite, usually numerous, free stamens, and a compound pistil. In Lschscholtzia the sepals are unitel, and the stamens adhere to the claws of the petals.

This small but interesting order of plants, with the exception of one species, is confined to the northern hemisphere. Fifteen species, belonging to eleven genera, are natives of the United States, and several European specics have become naturalizcd. Eschscholtzia and Platystemon are the most widely distributed of the California genera.

Romneya Coulteri is a half shrubby plant, with smooth pinnatifid leaves and very large white flowers (3, 4, or (ven 6 inches across), a native of the coast from San Diego to Santa Barbara County.

Arctomecon is another white-flowered plant, with somewhat hairy, nearly entire leaves; the petals persistent; found in south Nevada aud Utah.

Canbya, a recently discovered plant of south-east California, is the smallest of the order, being scarcely an inch in height. The small white petals are persistent.

Papaver Somniferum, a native of Asia, furnishes opium, which is the dried juice of the plant. A variety of this epecies is cultivated in this State for the seeds, from which is expressed poppy onl, used by artists. This oil is also used as a substitute for olive oil in the preparation of salads, et:.

* IIerbs with entire leaves, the uppermost whorled or opposite, sepals 3.

Filiform stigmas 6 to many (pistil hollow)................ Platystemon. I

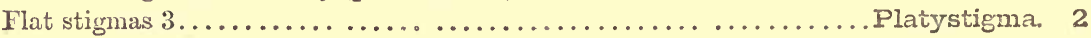

* * Herbs with divided or lobed leaves.

Sightly lobed stigma, style distinct; sepals $2 \ldots \ldots \ldots \ldots \ldots \ldots$............ 3 Filiform stigmas unequal; sepals united to form a conical cap....... Eschscholtzia. 4 Entire plant bristly with prickles; sepals 3, each with a horn......... Argemone. la

Buds globular; stigmas 2

$$
\text { ** }
$$

\section{Ia. $\triangle R G E M O N E, \mathrm{~L}$.}

Sepals 2 or 3 , spinosely beaked. Petals 4 or 6 . Stamens numerous, with linear anthers. Leaves sinuately pinnatifid, prickly toothed.

1. A. hispida, Gr. (Chicalote). Erect, armed with rigid bristles and prickles; leaves 3 to 6 inches long; flowers, nearly white, 2 to 4 inches in diamcter; capsule $1 \frac{1}{2}$ inches long.

\section{PLATYSTEMON, Benth. Cream-Cups.}

Sepals 3. Petals 6. Stamens many, with flattened filaments and linear anthers. Torulose carpels at first united; stigmas free.

I. P. Californicus, Benth. Slender, branching, 6 to 12 inches high; villons, with spreading hairs; leaves 2 to 4 inches long, sessile or clasping, broadly linear, obtuse, 
pale-green. Sepals hairy; petals pale-yellow, shading to orange in the center, 3 to 6 lines long.

\section{PLATYSTIGMA, Benth.}

Sepals 3. Petals 4 to 6. Stamens few or many, with narrow filaments. Ovary 3 -angled, oblong or linear; stigmas 3, ovate to linear. Low, slender annuals, resembling Platystemon in habit, with pale-green, entire, opposite or verticillate leaves and longpeduncled pale-yellow or creamy-white flowers.

1. P. lineare, Benth. Hairy, short-stemmed; stamens many, with dilated filaments; stigmas brcad; capsule ovate.

2. P. Californicum, Benth. \& Hook. Smooth, long-stemmed; stamens few (10 to 12) with filiform filaments; stigmas narrow; capsule linear.

\section{MECONOPSIS, Viguier.}

Sepals 2. Petals 4. Stamens numerous, with filiform filaments and oblong anthers. Style distinct; stigma 4-8-lobed. Seeds numerous.

1. M. heterophylla, Benth. Annual, smooth, slender, 1 to $2 \mathrm{ft}$. high; lower leaves long petioled, pinnately divided, the segments oval to linear and 2 to 12 lines long; upper leaves sessile; flowers scarlet to orange, the petals 2 to 12 lines long; peduncles elongated. Very variable.

\section{ISCHSCHOLIZIA, Chamisso.}

Sepals coherent into a narrow pointed hood, which drops off from the top shaped torus when the flower opens. Petals 4. Stamens numerous, with short filaments and long anthers. Smooth annuals, with colorless, bitter juice; finely dissected, pale-green alternate petioled leaves, and bright orange or yellow (rarely white) flowers.

1. I. Californica, Cham. Has stout branching stems, 1 to $1 \frac{1}{2} \mathrm{ft}$. high; flowers 2 to 4 inches in diameter, brilliant orange toward the center; capsule $2 \frac{1}{2}$ inches long, curved.

Var. Douglasii, Gr. More slender; flowers yellow.

Var. cæspitosa, Brewer. Scape-like peduncles; small yellow flowers.

\section{DENDROMECON, Benth.}

Scpals 2. Petals 4. Stamens numerous, with short filaments and linear anthers. Ovary linear; style short; stigmas 2, short and erect. The many seeded capsule dehiscent the wholc length by 2 valves separating from the placental ribs. A smooth branching shrub, with alternate vertical entire thick and rigid leaves and showy yellow flowers. The only true woody plant belonging to the order.

1. D. rigidum, Benth. A shrub 2 to $8 \mathrm{ft}$. high, with slender branches and whitish bark; leaves ovate to linear-lanceolatc, 1 to 3 inches long, very acuto or mucronate, sessilc or nearly so, twisted into a vertical position, margin rough or denticulate. 


\section{ORDER 5. FUIMTARIACE正.}

Tender herbs with dissected compound leaves, and irregular hypogynous flowers, the parts in twos, except the 6 diadelphous stamens.

\section{DICENTRA, Borkh.}

Sepals 2, small and scale-like, sometimes caducous. Corolla of two pairs of petals, flattened and cordate; the outer pair the larger and sacked at the base, the tips spreading; the inner, spoon-shaped, lightly united at the apex, inclosing the anthers and stigma. Stamens in two sets, 3 before each of the outer petals, filaments slightly cohering. Style slender; stigma 2-lobed, each lobe sometimes 2-crested.

1. D. formosa, DC. Leaves radical, and the compound racemes of rose-colored flowers borne on naked scapes.

2. D. chrysantha, Hook. \& Arn. The flowers in long terminal paniculate racemes on leafy stems; corolla narrow, scarcely cordate, golden yellow.

\section{ORDER 6. CRUCIFER 画.}

Herbs with pungent watery juice. Sepals 4. Petals 4, with blade narrowed into a claw, the lamina spreading to form a cross, rarely wanting. Stamens 6 , two of them inserted lower down on the receptacle and shorter than the other four. Ovary 2-celled by a thin partition, rarely 1-celled. Leaves alternate, and flowers usually in racemes without bracts.

Since a careful examination of the fruit is usually necessary for the determination of species in this difficult order, only such plants as have large flowers or remarkable fruit are here described.

\section{§ 1. Pod dehiscent, 2-valved.}

* Pod elongated, compressed parallel with the partition; seeds flat.

Pctioled leaves, lobed or divided; root tuberous................. Cardamine. I

Stem leaves sessile, entire; root perpendicular.

Flowers purple.................................................. 2

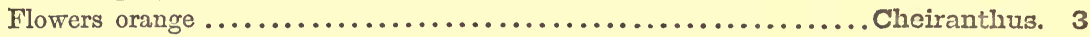

Flowers yellowish.................................... Erysimum. \&

* * Pod terete; seeds globose.

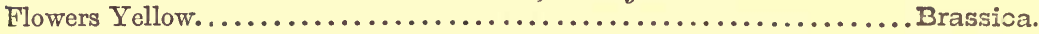

* * Pod flattened contrary to the partition.

Pod linear; flowers axillary, yellow.....................Tropidocarpum. 6

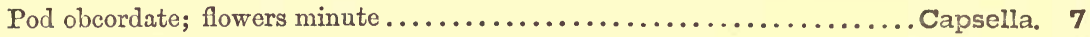
Pod obovate, 2 -winged at the top............................. 8 


\section{§2. Pod indehiscent, 1-celled.}

Pod orbicular, winged with a thin broad margin; flowers minute...Thysanocarpus. 9 Pod long, pithy; seeds large; flowers large, veiny.............. Raphanus. 10

\section{CARDAMINE, I.}

Pod linear, with somewhat thickened margins, merely pointed or beaked above; valves flat, nerveless. Seeds in one row somewhat flattened, wingless; cotyledons flat, accumbent. Sepals equal. Petals white or pinkish.

1. C. paucisecta, Benth. Stems from small deep-seated tubers, erect, 8 to 18 inches high; leaves various; the upper deeply lobed or parted, the lower often simple; petals 6 to 9 lines long; pods 1 to $1 \frac{1}{2}$ inches long.

\section{ARABIS. I.}

Pod linear; valves 1-nerved, not strongly. Seeds in 1 or 2 rows, flattened; cotyledons accumbent. Sepals short or narrow, rarely colored. Petals with a narrow claw, white, rose-colored, or purple.

1. A. blepharophylla, Hook. \& Arn. Stems often tufted 4 to 12 inches high; leaves strongly ciliate, sometimes sparingly sinuate-toothed, the lower obovate or broadly spatulate, the cauline oblong, sessile; petals bright purple, 6 to 9 lines long.

2. A. Breweri, Wat. Cespitose, canescent, with dense stellate pubescence; stems 2 to 10 inches high; petals 1 to 4 lines long, deep rose-color; sepals purplish; pods spreading or recurved.

\section{CHEIRANTHUS, L.}

Pod elongated, compressed; valves 1-nerved or carinate. Seeds in one row, flattened, not winged; cotyledons accumbent, or rarely oblique. Calyx not colored, the outer sepals strongly gibbous. Stigma with two spreading lobes.

1. C. asper, Cham. \& Sch. Rather sparingly pubescent with appressed 2-parted hairs; stem simple erect, leafy, 1 to $3 \mathrm{ft}$. high; leaves spatulate or oblanceolate, the lower long petioled, entire or sinuate-toothed; sepals broad 4 to 6 lines long, half the length of the bright yellow or orange petals; pods $1 \frac{1}{2}$ to 2 inches long.

\section{ERTSIMUM, L.}

Pod 4-angled by the prominent mid-nerve of the valves, not stipitate; cotyledons incumbent or oblique. Sepals, petals and stigma like the last.

1. I. asperum, DC. Similar to the last; sepals narrower; petals usually creamy white to yellow.

\section{BRASSICA, L. MUSTARD.}

Pod near?y terete or somewhat 4-sided, pointed with a long conical beak. Seeds in 
one row globose; cotyledons infolding the radical. Lateral sepals usualiy gibbous. Petals yellow.

1. B. campestris, L. Smooth; lower leaves pinnately divided, with a large terminal lobe; the upper leaves oblong or lanceolate, with a broad clasping base; pods 2 inches long or more.

2. B. nigra, Boiss. Larger; leaves all petioled; pods less than an inch long.

Not to be confounded with Sisymbrium officinale, Scop., which has runcinately pinnatifid leaves, small yellow flowers and closely appressed, subulate sessile pods half an inch long; or, with $\mathbf{S}$. acutangulum, DC., similar to the last, but the pods on short pedicels, erect and over an inch long. The last are called Hedge Mustards.

\section{TROPIDOCARPUM, Hook}

Pod linear, flattened, often 1-celled by the disappearance of the narrow partition. Seeds in two rows, minute; cotyledons incumbent. A low hirsute branching annual, with pinnately divided leaves, and yellow, solitary axillary flowers.

1. T. gracile, Hook. Stems weak; petals $1 \frac{1}{2}$ to 3 lines long, broad; pods 6 to 20 lines long, pointed at both ends.

\section{CAPSELIA, Mœnch. SHepHerd's PURse.}

Pod obcordate, much flattened, many-seeded; cotyledons incumbent. Slender and mostly smootl annuals, with minute flowers.

1. C. Bursa-pastoris, Mœnch. Somewhat hirsute at base; radical leaves mostly runcinate-pinnatifid, the cauline lanceolate, clasping.

2. C. divaricata, Walp. Very slender; pods elliptic-oblong; is more rare.

\section{IEPIDIUim, I. Peppergrass.}

Pod orbicular or obovate, emarginately 2 -winged at the summit; the cells 1-seeded. low herbs, with pinnatifid or toothed leaves, and small white flowers; the petals in some species wanting, and the stamens only 2 or 4 .

1. I. latipes, Hook. Stems stout, simple 1 to 3 inches high, surpassed by the irregularly and coarsely pinnatifid leaves; racemes capitate, in fruit an inch long or less; sepals very unequal; pod strongly reticulated, the acute wings nearly as long.

2. I. oxycarpum, Torr. \& Gr. Stems simple or branched 3 to 6 inches high; smooth; raceme lax, elongated; pod smooth, rounded, nodding, the broad acute teeth short and divergent; petals none.

3. I. nitidum, Nutt. Similar to the last, but larger; petals present; pods smooth and shining, acutely margined.

4. L. IMenziesii, DC. Hispid; petals none; pods not margined, except by the very short teeth at the summit. 
Var. (?) strictum, Wat. Sepals green, persistent; fruiting racemes crowded cylindric-capitate, the pedicels crect, low and spreading. This plant seems to be a separate species. It has been found in San Francisco, by Miss Annie Hughes.

\section{THYSANOCARPUS, Hook.}

Pod 1-celled, 1-seeded, plano-convex, mostly pendulous on slender pedicels. Flowers minute, white or rose-colored.

1. T. curvipes, Hook. Six inches to two feet high; the upper leaves clasping by a broad auricled base; pods densely tomentose or smooth, 2 to 4 lines in diameter, the wing entire or crenate, veined and often perforate, emarginate at the top and tipped with the purple style. The perforate-wing form called Lace-pod.

2. T. laciniatus, Nutt. Smaller and more slender; the cauline leaves scarcely auricled at the base; pods obovate, cuneate at the base, 2 to 3 lines long.

Var. crenatus, Brewer. The broader wing deeply crenate or fringed. Fringe-pod.

3. T. radians, Benth. Pods round, 4 to 5 lines in diameter, scarcely emarginate, with a broad entire translucent wing conspicuously marked by radiating nerves.

4. T. pusillus, Hook. May be known by its minute pods hirsute with hooked hairs.

\section{RAPHANUS, L. RADISH.}

Coarse introduced annuals.

1. R. sativus, L., has a pointed 2-seeded pod.

2. R. Raphanistrum, L., has a necklace-shaped pod, long beaked, 1-9-seeded.

\section{Order 7. CISTACEZF.}

Flowers perfect and regular. Sepals 5, persistent; and two of them smaller, wholly exterior, and bract-like. Petals 5, usually ephemeral. Stamens indefinite, with filiform filaments; anthers short. Style one. Capsule 3-valved.

\section{HELIANTHEMUM, Tourn.}

Petals broad. Stamens numerous (about 20). Style short; stigma 3-lobed. Low branching herbs, or somewhat woody; flowers yellow, opening only once, in sunshine.

1. II. scoparium, Nutt. Much branched, hairy or smooth, about a foot high; leaves narrow, 4 to 12 lines long, alternate; flowers on slender pedicels, one or several terminating the branches; petals 4 lines long.

\section{ORDER 8. VIOLACEZF.}

Herbs distinguished by the irregular one-spurred corolla of 5 petals, 5 stamens, adnate introse anthers conniving over the pistil, which has a club-shaped style with a one sided 
stigma, a one celled ovary, forming a capsule, which splits at maturity into three parts. Represented only by the familiar genus

\section{VIOLA, L.}

Sepals unequal, auricled at the base. Petals unequal, lower one spurred. Anthers nearly sessile, often coherent, the connectives of the two lower bearing spurs which are inclosed by the spur of the petal. (See Addenda.)

\section{* Leaves undivided.}

\section{+ Flowers not yellow, or orange.}

1. V. canina, L., var. adunca, Gr. Flowers violet or purple. Low stems sending out runners; leaves ovate, often somewhat cordate at the base, obscurely crenate; stipules foliaceous, narrowly lanceolate, lacerately toothed; spur as long as the sepals, curved; lateral petals bearded.

Var. longipes, Wat. The obtuse spur straight.

2. V. ocellata, Torr. \& Gr. Stems nearly erect, 6 to 12 inches high; leaves cordate to cordate-ovate, acutish, conspicuously crenate; stipules small, scarious; upper petals white within, purple-brown without, the others pale-yellow veined with purple.

$$
\text { + }+ \text { Flowers yellow, tinged with purple. }
$$

3. V. pedunculata, Torr. \& Gr. Stems with a decumbent or procumbent base; leaves rombic-cordate, with truncate or abruptly cuneate base, obtuse, coarsely crenate; stipules foliaceous, narrowly lanceolate, entire or gashed; showy flowers on peduncles exceeding the leaves; petals 6 to 9 lines long, the upper tinged with brown on the outside, the others veined with deep purple; lateral petals bearded; capsule smooth.

4. V. aurea, Kellogg. Leaves ovate to lanceolate, cuneate or sometimes truncate at base, obtuse, coarsely crenate; stipules foliaceous, lanceolate, laciniate; peduncle but little longer than the leaves; petals 4 to 6 lines long, as in the last, but lighter yellow; capsule pubescent.

5. V. Nuttallii, Pursh. Leaves oblong-ovate to oblong, attenuate into a long petiole, entire, or obscurely ininute; stipules entire; peduncles usually shorter than the leaves.

$$
+\div \div \text { Flowers yellow. }
$$

6. V. sarmentosa, Dougl. Leaves rounded-cordate, reniform, or sometimes ovate, finely crenate, usually punctate with dark dots. Flowers small.

\section{* * Leaves divided or lobed; flowers yellow, tinged with broun-purple.}

7. V. lobata, Benth. Distinguished by its stout stems and large palmately 5 to 9-lobed leaves. Flowers large.

8. v. chrysantha, Hook. Stems short; leaves bipinnatifid, with narrow seg* ments. Flowers large, like $\mathrm{V}$. pecunculata, but the lateral petals are not bearded. 


\section{ORDER 9. POLYGALACE无.}

Herbs or shrubs, with simple entire exstipulate leaves, remarkable for the papilionaccous-looking flowers. In our genus the ovary is 2-celled.

\section{POLYGALA, Tourn.}

Sepals 5, very unequal, the 2 lateral ones large and petal-like. Petals 3, united to each other and to the stamen-tube, the middle one hooded and often crested or beaked. Stamens 6 to 8, the filaments united below into a split sheath, adnate at the base to the petals. The 2-celled ovary forms a capsule flattened contrary to the partition, notched or retuse above.

1. P. cucullata, Benth. Stems slender from a woody base, 2 to 8 inches high; leaves smooth, oblong-lanceolate or ovate-elliptical, $\frac{1}{2}$ to 1 inch long, short petioled; flowers rose-color; outer sepals $2 \frac{1}{2}$ lines long, rounded-saccate at the base; the wings broadly spatulate, 4 to 6 lines long.

2. P. Californica, Nutt. Stouter; flowers greenish white.

\section{ORDER 10. CARYOPHYLIACE王.}

Herbs with regular and mostly perfect flowers, persistent calyx, its parts and the petals 4 or 5 and imbricated or the latter sometimes convolute in the bud, the distinct stamens commonly twice as many as the petals, ovary l-celled with a free central placenta. Stems usually swollen at the nodes. Leaves opposite, often united at the base by a transverse line, in one group with interposed scarious stipules. Styles 2 to 5 , mostly distinct. Fruit a capsule opening by valves, or by teeth at the summit. Flowers terminal, or in the forks, or in cymes.

Many species in this order are difficult to determine.

* Sepals united into a 4-5-toothed calyx. Petals long-clawed.

Petals with bifid appendages. ................................ Silene. I

$$
\text { * * Sepals distinct; petals without claws. }
$$

Petals bifid; capsule cylindric........................................... 2

Petals bifid capsule globose.................................. Stellaria. 3

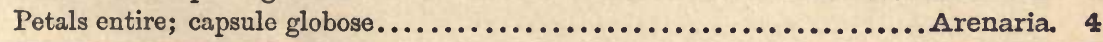

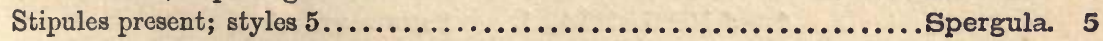

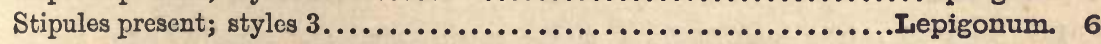

1. SICENE, L.

Calyx tubular, cylindrical to campanulate, 5-toothed, 10-nerved. Petals 5, with nar. 
row claws; the blade mostly bifid or many-cleft and usually crowned with 2 scalcs at the base. Stamens 10; styles 3, erect. Capsule dehiscent by 6 , rarely 3 teeth.

1. S. Gallica, L. Hairy; leaves spatulate, 1 to $l_{2}^{1}$ inches long; calyx oblongcylindric, becoming expanded by the growth of the ovoid capsule; flowers small, rosecolored, in one-sided close racemes; petals entire, slightly twisted.

2. S. Californica, Durand. Glandular-pubescent; stems 6 inches to $3 \mathrm{ft}$. high, lax, leafy; flowers large, deep scarlet, few at the ends of the branches; calyx 7 to 10 lines long; petals deeply parted with bifid segments, the lobes 2-3-toothed or entire, with often a lateral one.

3. S. Douglasii, Hook. Stems simple few-flowered; leaves narrowly oblanceolate to linear, an inch or two long; calyx oblong-cylindric, often inflated, 5 to 7 lines long; petals rose-color or nearly white; 8 to 10 lines long, bifid with broad obtuse lobes; claw broadly auricled; capsule oblong-ovate, long stiped.

\section{Cerastium, I. Motse-ear Chickweed.}

Sepals 5. Petals 5, emarginate or bifid. Stamens 10. Styles 5, rarely less. The curved capsule dehiscing by twice as many teeth as there are styles. Flowers white.

1. C. pilosum, Ledeb. Erect, rather stout, more or less densely pilose; leaves oblong-lanceolate, $\frac{1}{2}$ to an incl or more long, acute, almost sheathing at the base; flowers from $\frac{1}{2}$ to 1 inch in diameter.

C. ARVENsE, L., has downy acute leaves.

C. vULGatUM, L., has ovate or obovate obtuse leaves; flowers clustered.

\section{STeituaria, L. ChrckWeed.}

Sepals 5, rarely 4. Petals as many, 2-cleft. Stamens 10, or fewer by abortion. Low herbs with minute white flowers and 4-angled stems.

1. S. media, L. Weak and spreading, rooting at the lower joints; the ovate leaves less than an inch long on hairy petioles, or the upper ones sessile; stamens 3 to 10.

Introduced from Europe.

2. S. nitens. Nutt., has small sessile lanceolate leaves and narrow shining sepals surpassing the minute petals.

3. S. littoralis, Torr., is rather a stout hairy plant, with ovate leaves; flowers in a terminal cyme. May be found on the sea-shore.

\section{ARENARIA, L. SANDWORT.}

Distinguished chiefly from Stellaria by the entire petals and usually by the tufter stems and subulate rigid leaves. In our species the 3 valves of the capsule are entire; bracts foliaceous.

1. A. Douglasii, Torr. \& Gr. Slender, much branched, 3 to 6 inches high; leaves 
filiform, 3 to 12 lines long; flowers on long slender pedicels; sepals 3-nerved; petals obovate, 2 lines long or more; longer than the sepals.

2. A. Californica, Brew. Leaves lanceolate, 1 or 2 lines long; flowers smaller than the last; petals spatulate.

3. A. palustris, Wat. Stems weak, 4 to 8 inches high; leaves linear, flaccid, 6 to 12 lines long; flowers few on long pedicels; petals 3 or 4 lines long. In swamps.

\section{SPERGULA, L. CoRN-SPURry.}

Sepals 5. Petals 5, entire. Stamens 10, rarely 5. Ovary 1-celled, many-ovuled; styles 5, alternate with the sepals. Annuals dichotomously branched, with awl-shaped apparently whorled leaves (fascicled).

1. S. arvensis, L. The almost filiform leaves 1 or 2 inches long; flowers white, the Jnng pedicels at length reflexed. Naturalized.

\section{IEPIGONUM, Fries. SAND-SPURRY.}

Sepals 5. Petals 5, entire, rarely fewer. Stamens 10, or fewer by abortion. Ovary 1-celled, many ovuled; styles 3, or rarely 5. Low herbs, with setaceous or linear fascicled leaves; flowers white or pink, pediceled.

1. I. macrothecum, Fisch. \& Mey. Rather stout, often a foot high; leaves fleshy $\frac{1}{2}$ to 2 inches long, with large ovate stipules; pedicels becoming reflexed; sepals 3 or more lines long, equaling the pinkish petals. In salt-marshes.

2. I. medium, Fries. More slender than the last, with smaller flowers on shorter pedicels.

\section{ORder 11. PORTULACACE正.}

Succulent herbs, with simple and entire leaves, and regular but unsymmetrical perfect Alowers; the sepals only 2 , the petals 2 to 5 or more; the stamens opposite the petais when of the same number; the ovary l-celled. Stamens sometimes indefinitely numerous, commonly adhering to the base of the petals, these sometimes united at the base. Style 2 to 8-cleft. Stipules none.

*Sepals 2, distinct, persistent.

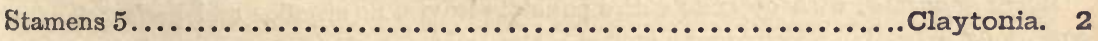

* Sepals 4 to 8 ............................................. Lewisia. 3

1. CAIANDIRINIA, H B K.

Petals mostly 5 (3 to 10). Stamens 5 to 15 . Ovary free, many-ovuled; style 3-cleft, short. Capsule globose or ovoid, 3-valved. Seeds shining-black. Low succulent herbs with alternate leaves. 
1. C. Menziesij, Hook. Smooth, branching from the base, the stems ascending; leaves linear to oblanceolate, 1 to 3 inches long, the lower on slender petioles; sepals keeled, the calyx 4-angled in the bud; petals broadly obovate, red to purple, 2 to 6 lines long. One of the most abundant of open ground early flowers.

\section{CLAYTONIA, L.}

Petals 5, cqual. Stamens 5. Style 3-cleft. Capsule and seeds as in Calandrinia. Radical leaves numerous; cauline perfoliate, or a pair.

1. C. perfoliata, Donn. Stems 2 to 12 inches high; radical leaves long-petioled, broadly rhomboidal, or deltoid, or deltoid-cordate, $\frac{1}{2}$ to 3 inches broad, obtuse; the cauline pair usually united to form an almost orbicular perfoliate leaf, concave above; the las raceme of small pinkish flowers nearly sessile in the leaf-cup.

Var. parviflora, Torr. Radical leaves linear, or linear-spatulate.

Var. spathulata, Torr. Radical leaves linear; the cauline pair distinct or partly united on one side, ovate to lanceolate. Low and slender.

Var. exigua, Torr. Low, radical leaves narrowly linear or filiform; the cauline distinct, linear.

2. C. Siberica, L. Stems 6 to 15 inches high; radical leaves lanceolate to rombicovate or nearly orbicular, long-petioled; the cauline pair ovate or varying from lanceolate to spatulate-obovate, sessile, distinct; raceme loose; the rose-colored or white petals 2 to 4 lines long.

\section{IEWISIA, Pursh.}

Petals 8 to 16, large and showy, rose-colored. Stamens numerous (40 or more). Style 3 to 8 -parted nearly to the base. Low acaulescent fleshy perennials, with fusiform roots, and short 1-flowered scapes.

1. L. rediviva, Pursh. Leaves densely clustered, linear-oblong, subterete, 1 or 2 inches long, smooth and glaucous; scape jointed in the middle, bearing on the juint 5 to 7 subulate verticillate bracts; petals sometimes white, 8 to 16 lines long.

\section{ORDER 12. HYPERICACE正.}

Herbs or shrubs, with opposite entire punctate leaves, no stipules and perfect flowers with 4 or 5 petals and numerous stamens, the fruit a septicidal many-seeded capsule. Calyx of 4 or 5 persistent sepals. Filaments mostly in 3 sets. Styles 2 to 5 , usually distinct.

\section{HYPERICUM, L. ST. JoHN's-wont.}

Sepals and petals 5. The numerous stamens in three bundles. Ovary 1 to 3-celled, the ovules growing on the parietal placentæ. Flowers cymose, yellow. 
1. II. Scouleri. Hook. Stems erect from a running rootstock $\frac{1}{2}$ to 2 fcet high, terete, simple or sparingly branched; leaves ovate to oblong, clasping, an inch or less long; petals punctate, 3 to 5 lines long; capsule 3 -celled.

2. I. concinnum, Benth. Stems from a woody base, 3 to 6 inches high; leaves from oblong to linear, acute, an inch long or less, not clasping, usually folded.

3. H. anagalloides, Cham \& Schleeht. Stems numerous, weak, rooting at the lower joints, 1 to 10 inches long; leaves broadly ovate or elliptical, 2 to 6 inches long, obtuse, clasping; sepals exceeding the petals; capsule 1-celled.

\section{ORDER 13. IMALVACEZ⿱乛龰.}

Herbs or shrubs with alternate stipulate leaves; distinguished by the valvate calyx, convolute petals, their bases or short claws united with the base of a column of many united stamens, these with reniform anthers. Calyx 5-cleft or parted, persistent, with sometimes a calyx-like involucel of bracts. Petals 5, usually withering without falling off. Pistil usually either a ring of ovaries around a projecting receptacle or a 3-10-celled ovary; styles united at least at the base. Leaves usually palmately ribbed. Flowers axillary. (See AdDEnda.)

\section{Lavatera, L. Tree Mallow.}

Involucel 3 to 6-cleft. Stamineal column divided into numerous filaments. Styles filiform. Fruit depressed; the several carpels separating from the prominent axis, 1-seeded.

1. I. assurgentiflora, Kellogg. A shrub 6 to $15 \mathrm{ft}$. high; flowers 1 to 4 in the axils on drooping pedicels; petals rose-purple, 1 to $1 \frac{1}{2}$ inches long, with a broad truncato limb and narrow claws having a pair of dense hairy tufts at the base. Commonly cultivated, but a native (?) of this State.

\section{MALVA, I. MaLlow.}

Involucel 3-leaved. Petals obcordate, small. Herbaceous. Otherwise as Lavatera. M. borealis, Wallman. Annual; leaves round-cordate, crenate, 5-7-lobed; peduncles short; petals pinkish-white, 2 or 3 lines long.

Distinguished from the biennial $M$. rotundifolia by its short pedunceles, small flowers and rugase carpels.

\section{SIDATCEA, Gr.}

Involucel none. Stamineal column double; the filaments of the outer series usually united into 5 sets, opposite the petals. Flowers in a terminal raceme or spike. Herbs.

\section{"Perennial.}

1. 5. malvæflora, Gr. Percnnial, 1 to $3 \mathrm{ft}$. high; leaves on elongated petioles, 
orbicular to semi-circular in outline; the lower toothed or cleft, the upper more narrowly and deeply, 5 to 9-lobed or parted; the segments sparingly toothed, often linear and entire; flowers in naked elongated racemes; bractlets small, lanceolate; pedicels short, naked; calyx often tomentose; petals emarginate, 6 to 12 lines long, purple; carpels smooth.

2. S. humilis, Gr. Much resembling the last, but lower, and often decumbent at the base; leaves smaller; flowers fewer and more scattered; calyx larger, 3 to 6 lines long; carpels reticulated and pubescent.

\section{* * Annual.}

3. 5. diploscypha, Gr. Pubescent with long spreading hairs, 1 to $2 \mathrm{ft}$. high; lcaves deeply 5-9-cleft with lobed segments; bractlets conspicuous, 5 to 7-parted, hispid; flowers nearly sessile in close 3 to 5 -flowered clusters; petals 6 to 12 lines long, broad and emarginate.

4. S. malachroides, Gr. Stout, hirsute, 3 to $6 \mathrm{ft}$. high, tufted; leaves large; flowers small, white or purplish, nearly sessile in close terminal heads on the short leafy branches; petals narrowly obcordate; sets of stamens indistinct.

\section{ORDER 14. LINACE再.}

A small order represented and characterized by the one genus

\section{IINUIM, L. Flax.}

Parts of the flower 5, except sometimes in the pistil. Filaments united at the base with commonly alternating teeth. Styles 5, or sometimes only 2 or 3 , distinct or united. Stigmas capitate or oblong; ovary globose. Seeds twice as many as the styles. Herbs with sessile entire leaves without stipules, and cymose or panicled flowers.

\section{§1. Styles 5. Flowers blue.}

1. I. perenne, L. Smooth, 1 to $2 \frac{1}{\mathrm{ft}}$. high, branching above, leafy; leaves linear to linear-lanceolate, 3 to 18 lines long, acute; stipular glands none; flowers on slender pedicels, scattered, large.

§ 2. Styles 3; pctals appendaged at base, with a tooth on each side and a third adnate to the inner face of the claw.

* Flowers yellow; pedicels short.

2. L. Breweri, Gr. Smooth, slender, 3 to 8 inches high or more, few flowered at the summit; leaves linear-setaceous, 6 to 8 lines long; stipular glands conspicuous; petals 3 or more lines long.

* Flowers rose-purple to white.

3. I. congestum, Gr. Nearly smooth, excepting the calyx, about a foot high; 
stipular glands very small; flowers in close terminal clusters; petals about 3 lines long; capsule globose.

4. I. Californicum, Gr. Smooth, glaucous, 6 to 18 inches high; stipular glands conspicuous; flowers in small cymes or the lower solitary; petals 4 lines long, capsule acute, shorter than the calyx.

5. S. spergulinum, Gr. Smooth, 6 to 15 inches high; leaves without stipular glands; pedicels 3 to 6 lines long, and mostly solitary; sepals slightly glandular, minute; capsule obtuse, exceeding the calyx slightly.

\section{ORDER 15. GERANIACEFH.}

Flowers perfect on axillary peduncles, regular (in our species) and symmetrical, the parts in fives. Stamens mostly in two sets, those alternate with the petals sometimes sterile. Ovary deeply 5-lobed, with a prolonged axis, or 5-celled.

\&1. Carpels 5, one-seeded, separating at maturity from the long central axis; the styles forming long twisted tails.

Fertile stamens 10; tails of the carpels not bearded................ Geranium. I Fertile stamens 5; tails of the carpels bearded................... Erodium. 2 § 2. Carpels 5 , one-seeded, fleshy, distinct...................... Limnanthes. 3 § 3. Carpels combined into a 5 -celled ovary........................ Oxalis. 4

\section{GeraniUin, L. Cranestill.}

Stamens 10 with anthers, a gland behind the base of each of the shorter 5; filaments bearded at the base. Ovary 5-lobed; style 5-lobed at the top; the roundish-oblong carpels splitting away from the persistent beaked axis. Leaves palmately lobed and mostly opposite, scarious stipules; swollen-jointed stems.

1. G. Carolinianum, L. Diffusely branched, pubescent; leares 1 to $2 \frac{1}{2}$ inches in diameter, palmately 5-7-parted, the divisions cleft into linear lobes; petals rose-colored equaling the awned sepals, 2 or 3 lines long; carpels hairy; tails half an inch long.

G. incisum, Nutt., with large purple flowers, grows in the Sierra Nevada, and in Humboldt County.

\section{ERODIUM, L'Her.}

Characters as in the last; but the filaments dilated, the 5 opposite to the petals sterile and scale-like; carpels attenuate to a sharp bearded base; the tails long bearded on the inner side. Leaves commonly pinnate and bipinnately parted or lobed; peduncles umbellately 2-several-flowered with a 4-bracted involucre at the base of the pedicels; flowers small.

1. ॄ. cicutarium, L'Her. (Filaria or Pry-Clover.) Hairy, much branched, 
decumbent; leaves pinnate the leaflets laciniately pinnatifid with narrow acute lobes, the opposite leaves unequal; the long peduncles in the axils of the smaller leaves bearing 4 to 8-flowered umbels; the slender pedicels at length reflexed, the fruit still erect; the bearded carpels with spirally twisted tails.

2. E. moschatum, L'Her. (Musky Filaria.) Similar to the last but of a lighter green and the leaflets unequally and doubly serrate, not pinnatifid. Gives out a musky odor when wilted.

3. Đ. macrophyllum, Hook. \& Arn. Leaves reniform-cordate, 1 to 3 inches broad; sepals broad, 5 to 6 lines long.

\section{LIMNANTHES, R. Br.}

Glands 5, alternating with the petals. Stamens 10. Style 5-cleft at the apex. Annual low diffuse herbs, with pungent juice, growing in wet places; leaves pinnate, without stipules; flowers yellowish-white or rose-colored, solitary on axillary peduncles.

1. I. Douglasii, R. Br. Glabrous, yellowish green, weak and succulent stems; leaflets incisely lobed; peduncles at length 2 to 4 inches long; sepals lanceolate, 3 to 4 lines long, half the length of the oblong or obovate, emarginate or truncate petals.

Var alba, Hartweg. Villous sepals; shorter, white petals.

\section{OXAIIS, L.}

The parts of the flower in fives. Stamens 10; the filaments dilated and united below. Capsule columnar or ovoid, beaked with the short style. Low herbs with sour watery juice; leaves alternate or radical, digitately trifoliolate, leaflets obcordate.

1. O. Oregana, Nutt. (Redwood Sorrel.) Acaulescent, rusty-villous; rootstock creeping; leaflets broadly obcordate, 1 to $1 \frac{1}{2}$ inches broad; petioles 2 to 8 inches long; scapes equaling or exceeding the leaves, mostly 1-flowered; petals 6 to 12 lines long, white or rose-colored, often veined with purple.

2. O. corniculata, L. (YELLOw SorReL.) Distinguished by its slender branching stems, and smaller yellow flowers.

\section{ORDER 16. RUTACERF.}

Pellucid or glandular-dotted aromatic leaves, along with definite hypogynous stamens and definite seeds characterize this order, although some of the orange-tribe have many stamens.

\section{PTELEA, L. Hop-tree.}

Flowers polygamous. Sepals, petals and stamens 4 or 5 ; ovary with a short, thick 
stipe, 2-celled; style short; fruit a broadly winged orbicular samara, 2-sceded. Flowers small, greenish-white, in terminal cymes or compound corymbs.

1. P. angustifolia, Benth. A shrub 5 to $25 \mathrm{ft}$. high, with chestnut colored punc. tate bark; leaves 3 -foliolate.

\section{ORDER 17. CELASTRACE无.}

Sufficiently characterized by the genus

\section{IUONYMUS, Tourn.}

Sepals and petals 4 or 5, widely spreading; Stamens as many very short on an angled disk; ovary immersed in the disk, 3-5-valved, colored, often warty. Fruit a red aril. Shrubs, with 4-angled branches, opposite petioled exstipulate serrate smooth leavcs, and lowers in loose cymes on axillary peduncles.

1. E. occidentalis, Nutt. 7 to $15 \mathrm{ft}$. high; leaves ovate to oblong-lanceolate, acuminate, serrulate, 2 to 4 inches long; peduncles $1-4$-flowered; flowers dark reddishbrown, 4 to 6 lines in diameter, the parts in fives.

\section{ORDER 18. RHAMINACEAE.}

Shrubs or small trees, with simple undivided leaves, small and often caducous stipules, and small regular flowers, the stamens borne on the calyx and alternate with its lobes; ovary 2 to 4-celled. Flowers often apetalous; a conspicuous disk adnate to the short tube of the calyx; petals often clawed; style or stigma 2-4-lobed; fruit berry-like or dry, containing 2 to 4 seed-like nutlets.

Calyx and disk free from the ovary; filaments short; fruit berry-like..... Rhamnus. I Calyx and disk adherent to the ovary; filaments long; fruit dry........ Ceanothus. 2

\section{RFAMNUS, L.}

Small greenish flowers; calyx 4-5-cleft, with erect or spreading lobes, the campanulate tube persistent; petals 4 or 5 or none, on the margin of the disk; claws short; stamens 4 or 5; leaves evergreen.

\section{§1. Flowers diocious, apetalous, solitary or fascicled in the axils.}

1. R. crocea, Nutt. Much branched, 3 to $15 \mathrm{ft}$. high; leaves coriaceous, oblong or obovate to obicular, 3 to 18 lines long, acutely denticulate, usually yellowish brown or copper-colored beneath; fruit red.

\section{§ 2. Flowers mostly perfect in pedunculate cymes.}

2. R. Californica, Esch. Spreading 4 to $18 \mathrm{ft}$. high; leaves ovate-oblong to ellip- 
tical, 1 to 4 inches long, denticulate or nearly entire; petals very small, broadly ovate, emarginate; fruit blackish-purple.

\section{CEANOTHUS, L.}

Calyx 5-cleft; the lobes acute; disk thick adhering to the tube and to the ovary; petals on long claws, hooded; stamens 5; filaments long-exserted; ovary 3-lobed; style short, 3-cleft. The small flowers are in showy thyrsoid or cymose clusters. Species difficult.

\section{§1. Leaves 8-nerved.}

1. C. thyrsiflorus, Esch. (Califoria Lilac.) Smooth, 6 to $15 \mathrm{ft}$. high; branches strongly angled; leaves rather thick, oblong to oblong-ovate, 1 to $1 \frac{1}{2}$ inches long, usually smooth and shining above, canescent beneath; flowers bright blue in dense compound racemes, terminating the long and somewhat leafy peduncles.

2. C. integerrimus, Hook \& Arn. Slender, 2 or $3 \mathrm{ft}$. high; branches round, usually warty; leaves thin, bright green, ovate to ovate-oblong, 1 to 3 inches long; thyrse large, white-flowered.

3. C. dentatus, Torr \& Gr. Low, not rigid; leaves small glandular-serrate, fascicled, the margin strongly undulate or revolute, somewhat resinous; flowers bIne, in small roundish elusters.

4. C. sorediatus, Hook \& Arn. Rigid; inflorescence pubescent; leares silky on the nerves, $\frac{1}{2}$ to $1 \frac{1}{2}$ inches long; flowers blue in shortly peduncled simple racemes $\frac{1}{2}$ to 2 inches long.

5. C. divaricatus, Nutt. Grayish, usually spinose; leaves small, not tomentoso bcneath; flowers light blue or white, in nearly simple often elongated racemes, 1 to 4 inches long; fruit resinous.

6. C. incanus, Torr \& Gr. Spinose; leaves hoary beneath with a very minute tomentum, cuneate to cordate at base; flowers in short racemes, white; fruit resinously warty. A straggling shrub along creeks.

\section{§2. Leaves pinnately veined.}

7. C. papillosus, Torr. \& Gr. More or less hispidly villous or tomentose, 4 to 6 ft. high; leaves glandular-serrulate, and the upper surface glandular-papillose, narrowly oblong, 1 to 2 inches long on slender petioles; flowers blue, in close clusters or short racemes, terminating slender naked peduncles; fruit not resinous.

§3. Leaves small, often opposite, very thick, with numerous straight lateral veins; stipules mostly large and warty; flowers in sessile or shortly peduncled axillary clusters; firit larger, with 3 horn-like or warty prominences below the summit.

8. C. crassifolius, Torr. Erect 4 to $12 \mathrm{ft}$. high, the young branches white with a villous tomentum; leaves somewhat spinosely-toothed or rarely entire and revolutely margined; flowers light blue or white, in dense clusters. 
9. C. cuneatus, Nutt. Similar to the last, but less tomentose; leaves cuneateobovate or oblong, retuse above, on slender petioles; flowers in looser clusters.

10. C. rigidus, Nutt. Erect, $5 \mathrm{ft}$. high, the branchlets tomentose; leaves 2 to 5 lines long, cuneate-oblong or broadly obovate, few toothed above, very shortly petioled; flowers bright blue.

ORDER VITACEF has but one representative; the well-known California wild grape, Vitis Californica, Benth., which is common on the woody banks of streams.

\section{OrDER 19. SAPINDACEF.}

Trees or shrubs, mostly with compound or lobed leaves, with unsymmetrical or irregular flowers; the order best characterized under its suburders.

Under the order proper belongs

\section{ZESCULUS, L. BUCKEYE.}

Leaves opposite, palmately 4-7-foliolate. Calyx tubular, unequally 5-toothed. Petals 4 or 5 , unequal, with claws. Stamens 5 to 7 , exserted and often unequal. Ovary 3-celled; style long. Fruit a large leathery 3-valved pod.

1. F曰. Californica, Nutt. Leaflets, usually 5, smooth, oblong-lanceolate, acute, obtuse at base, slenderly petiolulate, serrulate, 3 to 5 inches long; flowers in a close finely pubescent thyrse which is 6 to 12 inches long; calyx 2-lobed, the lobes scarcely toothed; petals white or pale rose, half an inch long or more; stamens 5 to 7 ; anthers orange colored. Fruit pear-shaped, $1 \frac{1}{2}$ to 2 inches long, containing, usually, one seed.

\section{SUB-ORDER. ACERINEZE.}

Flowers polygamous or dioecious, regular, often apetalous. Ovary 2-lobed and 2-celled, each 1 -seeded cell producing a wing. Leaves opposite without stipules.

\section{ACER, Toum. MAPLE.}

Leaves palmately lobed. Calyx colored. Petals, usually 5. Stamens 3 to 12 inserted with the petals on a lobed disk. Styles 2. Fruit divaricately 2-winged.

1. A. macrophyllum, Pursh. (Large-leafed Maple.) A tree 2 or 3 feet in diameter; leaves 6 to 10 inches in diameter, deeply 3-5-cleft; flowers fragrant, yellow, in crowded pendulous racemes; fruit densely hairy; the smooth wings $1 \frac{1}{2}$ inches long.

2. A. circinatum, Pursh. (Vine-Maple.) A shrub or small tree; leaves $\mathbf{3}$ to $\mathbf{5}$ inches broad, 7-9-lobed, lobes sharply serrate; flowers in corymbs loosely 10-20-flowered, on slender 2-leaved branchlets; sepals red or purple, exceeding the greenish petals; fruit smootir. 


\section{NEGUNDO, Mœnch. Box-Eldir.}

Flowers diœeious. Calyx minute. Petals and disk none. Stamens 4 or 5. Ovary and fruit as in Acer. Trees; leaves pinnate; sterile flowers on clustered capillary pedicels, the fertile in drooping racemes.

1. N. Californicum, Torr. \& Gr. Usually a small tree; leaves 3-foliolate, villous; leaflets ovate or oblong, acute, 3 or 4 inches long, the terminal largest and 3-5-lobel or coarsely serrate, the lateral ones coarsely serrate; fruit pubescent; wings slightly sireading.

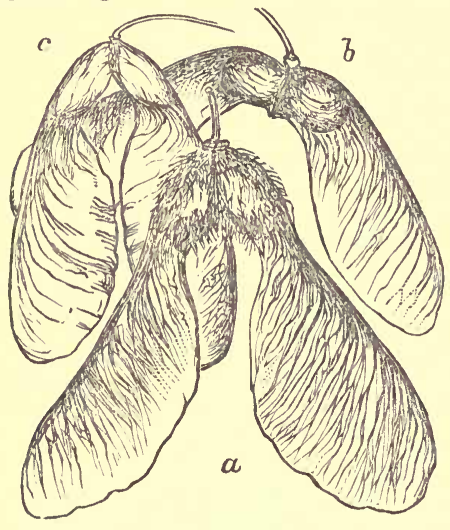

In the figure $a$ represents the fruit of Acer macrophyllum, $b$ the wider spreading samara of $A c e$. circinatum, and $c$ the closer wings of Negunds Californicum. The first has hairy carpels; the second is smooth, and the last slightly hairy.

ORDER ANACARDIACD疋 is represented by the well-known Poison Oak or Rhus dirersiloba, a slender, sometimes climbing, shrub, resembling the eastern Rhus toxicodendron, which is also often called Poison Oak, but is more commonly known as Poison Ivy. The eastern Sumac belongs to the same genus. There are three other species of Rlius in the State. The Pepper tree (Schinus molle), so commonly eultivated as an ornamental shade tree, belongs to this order.

\section{ORDER 20. LEGUMINOS正.}

The single and simple free pistil becoming a legume in fruit, the alternate leaves with stipules, and in our genera, the papillionaceous corolla with 10 stamens, mark this order, one of the largest and most important in the vegetable kingdom.

Flowers irregular. Calyx $3-5$-cleft or toothed, persistent. Corolla of 5 petals, the upper larger and always external, covering the lateral pair in the bud, and these covering the lower pair, which are more or less united, forming a keel which encloses the stamens and pistil. Filaments 10, rarely 5, commonly united around the pistil, either all united or nine and the upper one free. Ovary forming a pod with a single row of seeds attached to one side; style usually inflexed or curved. In Cercis the upper petal is small and enclosed by the wings. In Amorpha there is but one petal.

Suborder Cæsalpineæ is marked by the upper petal enclosed, and distinct stamens.

Suborder Mimoseæ has regular flowers and usually many conspicuous stamens. 


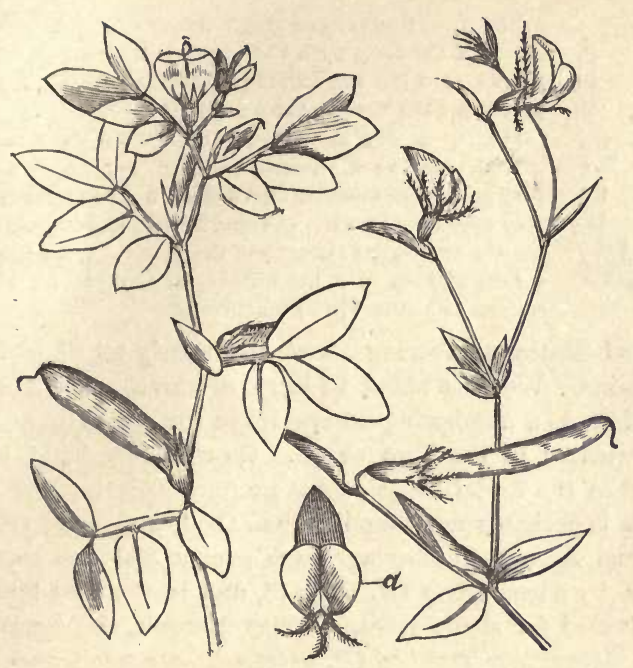

A

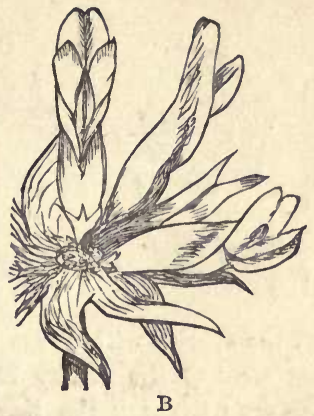

Fig. A. On the left is Mosaclia subpinnata, showing a full grown pod and a flower as seen from above. On the right is a pod and flowers of Hosackia Purshiana. At $a$ is a single flower with its bract as seen from the front. The lower leaves and bracts are larger.

Fig. B. A head of Trifolium fucatum, with all but three of the flowers

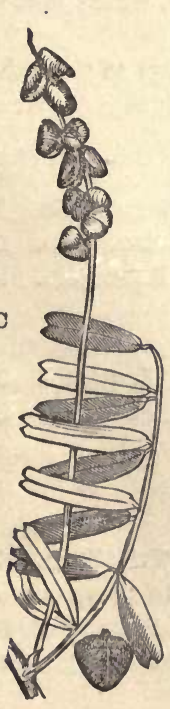
removed, showing the common receptacle and the involucre.

Fig. C. An axillary spike of Astragalus didymocarpus, with ripe fruit. Helow is one of the pods magnified.

This order is remarkable for the number of useful and beautiful plants which belong to it. Pease, beans, lentils, peanuts, clover, alfalfa, ctc., furnish food for man and domestic animals. Tropical plants of this order supply, among others, the following articles of commerce: Gum arabic, gum senegal, gum copal, dragon's-blood, incligo, logwood, brazilwood, rosewood, tamarind. Many species have medical value, as senna, catchu, copaiba, etc.

There are over 6,000 species of leguminous plants, mostly tropical. About 350 species are natives of the United States, more than half of which are found in California. Only 4 or 5 species are common to this coast and the Atlantic States, and these have forms peculiar to each, coast. Our 180 species are grouped under 14 genera, while the 150 species of the East (i. e., the Mississippi States and eastward to the Atlantic), represent 50 genera. There are about 40 species of lupine, and the same number belonging to the genus Astragalus, growing within the limits of this State. Only two kinds of the former and 4 of the latter grow east of the Mississippi. The latter is the largest American genus of the 

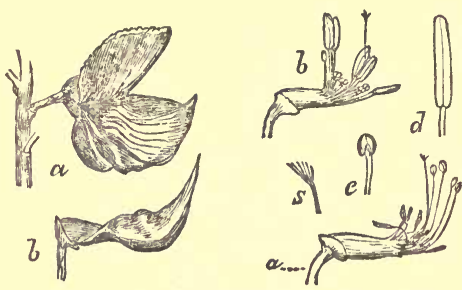

Fig. A. At $a$ is seen a single flower of Lupinus Dou. glasii; $b$, the same with the upper and side petals re. moved, showing the united pair of long-clawed, lower petals and the base of the stamineal tube.

Fig. B. a. The same flower with all the petals removed, showlng the united stamens, 5 of which have shed the pollen and crinkled down. $b$. The stamens as they appear in a bud. The shorter stamens of the bud become the longer stamens of the flower. $c$. Anther of a long stamen in $a$ magnified. $d$. Anther of a long stamen in $b$ (short in $a$ ) magnified.

order, the species within the United States numbering about 150, nearly all of which belong west of the Rocky Mountains. We have abont 25 kinds of clover; only 3 or 4 species are natives of the East. Hosackia, numbering 28 species in our whole country, 25 of which grow here, is not represented in the East at all. On the other hand, the large genus Desmodium, numbering in the East 19 species, has no representative west of the Rocky Mountains. Pickeringia is probably not found beyond the boundary of California. The great Australian genus Acacia, numbering there nearly 300 species, is represented in Southern California by a small tree (A. Greggii), and in the Last by an herb. Possibly 30 species are cultivated for shade trees. Honey Mesquit, or Algaroba (Prosopis juliflora) and Screw-pod Mesquit, or Tornilla ( $P$. pubescens), are small trees of Southem California. Prosopis and Acacia belong to the Suborder Mimosex. All the plants here described (except Cercis) belong to the Suborder Papilionaceæ, which is distinguished by flowers, like those of the pea, as before described.

Cercis, which, by mistake, is not described in the proper place, belongs to the Suborder Cæsalpineæ, in which the side petals enclose the upper one and the stamens are free.

\section{§1. Stamens distinct.}

Leaves digitately 3 -foliolate. Herbs; yellow flowers.............. Thermopsis. I Shrub; purple flowers................................. Piclreringia. 2 Leaves unequally pinnate; shrubby; 1 petal.................... Amorpha. 9

\section{§ 2. Stamens all united into a sheath.}

Anthers of two forms; leaves digitate, more than three leaflets........... Lupinus. 3 Anthers all alike; leaves pinnately 3 -foliolate...................... Psoralea. 8

§ 3. Stamens diadelphous (2 sets, 9 and 1).

* Leaves S-foliolate; pods small.

Flowers capitate. Corolla persistent....................... Frifolium. 4 Flowers in axillary racemes or spikes. Pod globular, wrinkled..........Melilotus. 5

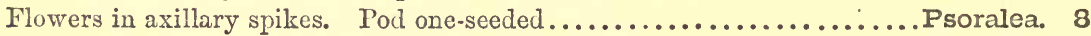
Pod spirally coiled or reniform.............................edicago. 6 
* Leaves unequally pinnate; leaflets entire; no tendrit.

Flowers umbellate or solitary, axillary................................... 7 Flowers white or pinkish. Pod short, prickly.................. Glycyrrhiza. 10

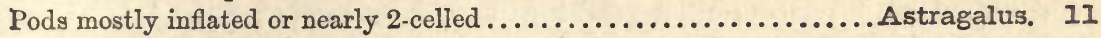

* * * Leaves terminated by a tendril or bristle or an imperfect leaflet.

Style filiform, hairy around the apex........................ Vicia. 12 Style flattened dorsally toward the apex, hairy on the inner side, usually

twisted half round............................. Iathyrus. 13

1. THERMOPSIS, R. Br.

Calyx companulate, cleft to the middle. Standard roundish, shorter than the oblong wings, the sides reflexed; keel nearly straight, its petals somewhat united, equalling the wings. Perennial herbs with the aspect of Lupine; leaflets entire; stipules foliaceous; flowers large in long terminal racemes, with persistent bracts.

1. T. Californica, Wat. Woolly-tomentose; stipules lanceolate; leaflets obovate to oblanceolate, an inch or two long; bracts ovate; pod hairy.

\section{PICKERINGIA, Nutt.}

Calyx campanulate, turbinate at the base, repandly 4-toothed. Petals equal; staudard orbicular, the sides reflexed; wings oblong; keel petals oblong, distinct, straight, obtuse. A low stout much branched spinose shrub; leaves evergreen, small, nearly sessile, 1-3-foliolate, without stipules; flowers large, solitary, axillary, nearly sessile.

1. P. montana, Nutt. Spreading, densely branched, 4 to $7 \mathrm{ft}$. high, silky-tomentose or smooth; leaflets 3 to 9 lines long; flowers from light cinnamon-red to purple, 7 to 9 lines long; stamens persistent.

\section{LUPINUS, L. LUPINE.}

Calyx deeply bilabiate, bibracteolate. Standard broad, the sides reflexed; wings united at the ends, enclosing the incurved beaked keel. Stipules adnate to the petioles; leaflets entire. Flowers in terminal racemes, verticillate or scattered, bracteate.

A large and difficult genus.

* Annuals.

Ovules 2; bracts persistent; flowers in whorls; leaves long petioled, approximate; stout. Long-villous; flowers mostly purple................... L. microcarpus. 15 Smoother; flowers yellow to white..................... densiflorus. 16

Ovules several; bracts deciduous; flowers in whorls; petioles 1 to 3 times the length of the leaflets.

Puberulent; leaflets broad, smoother above; bracts short............. L. afinis. 8 
Villous; leaflets narrow, both sides pubescent.

Bracts elongated; flowers rather large...................... nanus. 9

Bracts short; flowers small, narrow.................... micranthus. 10

Ovules several; bracts somewhat persistent; flowers scattered; petioles 1 to 4 times the length of the leaflets.

Slender; leaflets smooth above; bracts long................. I. leptophyllus. II Slender; leaflets linear; bracts short...................... sparsiflorus. 12 Stout; leafiets truncate; bracts short....................... truncatus. 13 Stouter; leaflets broad; bracts short; very hispid............I. hirsutissimus. 14

* * Perennials; herbaceous, tall; flowers large; ovules 8 to 12.

Stout; long petioles; leaflets 10 to 16 , very large............... polyphyllus. 4 Stout; short petioles; leaflets 7 to 10 , large................... rivularis. 5 Slender, decumbent; short petioles; leaflets small............... littoralts. 6 Stoutish, erect; short petioles; keel narrow, falcate............... albicaulis. 7

* * * Perennials; shrubby, leafy, silky-pubescent.

Leaflets narrowly lanceolate; flowers yellow................... arboreus. 1 Densely silky-pubescent; flowers blue to white................ Chamissonis. 2 Pubescence short, tomentose; shrubby at the base............... Douglasii. 3

1. I. arboreus, Sims. Often 4 to $8 \mathrm{ft}$. high; sulphur-yellow, fragrant flowers, verticillate in a loose raceme; pods large, pubescent, 10-12-seeded.

2. I. Chamissonis. Esch. Less shrubby, 1 to $4 \mathrm{ft}$. high; leaflets 7 to 9 , cuneate obovate, a half to an inch long, very silky on both sides; bracts lanceolate, shorter than the calyx; flowers sub-verticillate, blue, violet, rarely white. A variety about San Francisco with long bracts.

3. 工. Douglasii, Agardh. Slightly woody at base; pubescence short, tomentose or silky; leaflets 7 to 9 , oblanceolate to cuneate-oblong, 1 to $1 \frac{1}{2}$ inches long, pubescent on both sides; bracts linear-setaeeous, exceeding the calyx; flowers, blue or purple; calyx with long setaceous bractlets.

4. I. polyphyllus, Lindl. Stout, erect, 2 to $5 \mathrm{ft}$. high, sparingly villous; stipules large, triangular to subulate; leaves distant, long petioled; leaflets 2 to 6 inches long; racemes a foot or two long; flowers mostly scattered on long pedicels, blue, purple or white; bracts oblanceolate, equaling or shorter than the calyx; keel naked.

5. L. rivularis, Dougl. Stout, erect, 2 to $6 \mathrm{ft}$. high, nearly smooth; stipules subulate or setaceous; leaflets 7 to 10 , about equaling the petioles, $\frac{1}{2}$ to 5 inches long; raceme often 1 tc $2 \mathrm{ft}$. long; bracts setaceous, exceeding the calyx; flowers purple or rarely white; keel slightly ciliate.

6. L. littoralis, Dougl. Stems slender decumbent or ascen\&ing, 1 or $2 \mathrm{ft}$. long; leaflets a half to an inch long, at least half as long as the petioles; flowers blue or violet. with some yellow, in short racemes; keel ciliate; calyx large, with small bractlets. 
7. albicaulis, Dougl. Distinguished by its flowers; which are light-blue to white, the standard strongly reflexed, the margins cohering near the apex, naked, acute; the narrow keel very strongly falcate.

8. I. affinis, Agardh. Stem a foot high; leaflets broadly wedge-obovate, emarginate or obtuse, an inch long or more; the petioles twice longer; petals 5 lines long; the keel usually naked; bracts short.

9. L. nanus, Dougl. Slender stem 6 inches to a foot high, villous, often branching from the base; leaflets linear to oblanceolate, half to an inch long, the petioles 1 to 3 times longer; bracts exceeding the calyx; petals very broad, 5 to 6 lines long, bluishpurple, or at first nearly white; the standard shorter and usually marked with purple lines.

10. I. micranthus, Dougl. Similar to the last, but the flowers smaller, in usually shorter more dense racemes; bracts shorter than the calyx; petals 2 to 3 lines long, narrow.

Var. microphyllus, Wat. The lower and more hirsute form, with leaflets but 3 to 6 lines long.

Var. bicolor, Wat. Flowers larger, more like L. Nanus.

Var. trifidus, Wat. Very hairy; lower lip of the calyx 3-parted.

11. I. leptophyllus, Benth. Rarely branched, 1 or $2 \mathrm{ft}$. high, villous; leaflets narrowly linear on slender petioles; smooth above; bracts sctaceous, much exceeding the calyx; petals 5 or 6 lines long, bluish-lilac, with a deep crimson spot upon the standard.

12. I. sparsiflorus, Benth. Very slender, sparingly branched, 1 to $1 \frac{1}{2} \mathrm{ft}$. high, villous, with spreading hairs; upper leaves very small; leaflets 5 to 9 , linear, $\frac{1}{4}$ to 1 inch long; petals violet, 5 lines long, the standard shorter; pod half an inch long.

13. L. truncatus, Nutt. Stout, branched, 1 to $2 \mathrm{ft}$. high; leaflets linear, narrowed from the truncate or somewhat 3 -toothed apex to the base, smooth above, $\frac{3}{4}$ to $1 \frac{1}{2}$ inches long, nearly equaling the petiole; petals deep-purple, 4 or 5 lines long, the standard shorter; pod about an inch long.

Here belongs I. STiverr, Kellogg. A beautiful species of the Sierra Nevada, with yellow standard and rose-colored wings.

14. I. hirsutissimus, Benth. A foot high or more, very hispid, with spreading straight and viscid stinging hairs; leaflets broadly cuneate-obovate, obtuse or retuse, rarely acute, mucronulate; flowers in loose racemes, reddish-purple, large.

15. I. microcarpus, Sims. Villous, with long hairs, 6 to 18 inches high; leaves approximate on long petioles; leaflets usually 9 , cuneate-oblong, obtuse or emarginate, smooth above, 1 to 2 inches long; calyx densely villous, large; petals purple to white, 6 or 7 lines long; the hairy 1-2-seeded pods 8 lines long.

16. I. densiflorus, Benth. Much resembling the last; calyx smooth or finely pubescent; petals yellow or ochroleucous, rarely white or pink.

L. luteolus, Kellogg, may be found, distinguished by its more slender habit, smaller and fewer leaflets, and bracts exceeding the calyx. 


\section{TRIFOLIUM, L. ClOVER.}

Calyx 5 cleft with nearly equal teeth, persistent. Corolla withering, persistent; wings narrow, keel short obtuse. Stamens usually diadelphous. Style filiform. Pod small and usually inclosed in the calyx, membranaceous, indehiscent or dehiscent at the ventral suture, 1 to 6 -seeded. Herbs with leaves palmately 3 or rarely $5-7$-foliolate; stipules adnate to the petiole; flowers in capitate racemes, spikes or umbels, rarely few or solitary; peduncles axillary or only apparently terminal.

All our species annual.

\section{$\S 1$. Heads not involucrate; ovules 2.}

* Hleads apparently terminal; flowers sessile, not reflexed; calyx teeth plumose, filiform.

1. э. Macræi, Hook. \& Arn. Somewhat villous, erect, 6 to 12 inches high; stipules ovate to lanceolate; leaflets obovate to narrowly oblong, obtuse or retuse, serrulate. about half an inch long; flowers dark purple, 3 lines long, in dense ovate long peduncled heads; calyx very villous; the straight teeth as long as the petals, often tinged with purple; pod 1-seerked.

Var. dichotomum, Brew. A taller and stouter form, with larger flowers in heads zuearly an inch long; corolla more conspicuous, tipped with white.

* * Heads axillary, small; flowers on short pedicels, at length reflexed; calyx teeth subulate; mostly smooth.

2. T. ciliatum, Nutt. Erect; often 1 to $2 \mathrm{ft}$. high; leaflets similar to the last; corolla white or purplish, little exserted, 3 lines long; calyx tube campanulate; the lanceolate teeth very acute, rigid, the scarious margin rigidly ciliate.

3. T. gracilentum, Torr. \& Gr. Erect, slender, a foot high or less; stipules lanceolate; leaflets cuneate oblong to ovate or obcordate, retuse, about half an inch long, serrulate; flowers pale rose-color or purplish on pedicels a line long or less; calyx campanulate, the subulate teeth nearly equaling the corolla.

4. bifidum, Gr. Exactly like the last, but the leaflets narrow, the sides sparingly toothed or entire, and all deeply notched or cleft at the apex.

§ 2. Heads subtended by an involucre; peduncles axillary; flowers sessile, not reflexed. * Involucre not membranaceous, deeply lobed, and the lobes laciniately and sharply toothed; corolla not becoming inflated.

5. T. involucratum, Willd. Smooth; stems ascending, often a span high or more; leaflets mostly oblanceolate and acute at each end, a half to an inch long; flowers half an inch long, in close heads, purple or rose-colored; the narrow calyx teeth all entire; ovules mostly 5 or 6 .

Var. heterodon, Wat. Heads larger and leaflets broader; some of the calyx tecth setaciously cleft.

6. tridentatum, Lindl. Smooth or glandular-puberulent, slender and usually erect, 
a half to two feet high; leaflets linear to narrowly lanceolate, sharply scrrate; heads rather large, the flowers 6 to 8 lines long, purple, often tipped with white; calyx strongly nerved; the rigid teeth usually shorter than the tube, abruptly narrowed into the spinulose upex, often with a stout tooth on each side; ovules usually 2.

Var. obtusiflorum, Wat. Stouter and often glandular-puberulent, with broader leaflets and larger flowers; calyx teeth entire.

7. T. pauciflorum, Nutt. Smooth, very slender; stems ascending or decumbent; leaflets obovate to oblanceolate or sometimes linear, half an inch long or less, serrulate; heads few flowered; involucre small; flowers 3 or 4 lines long, not much exceeding the calyx; deep purple to light rose-colored; calyx teeth subulate, entire; pod 2-seeded.

* Involucre membranaceous, at least at the base, less deeply lobed; corolla not inflated.

8. T. microcephalum, Pursh. Villous, with soft hairs, slender, erect or decum. bent; stems often a foot or two long; leaflets oblanceolate to obovate, usually retuse, serrvate; heads small, dense; involucre about 9-lobed, the lobes acuminate 3-nerved, entire; calyx hairy, nearly equaling the white or light rose-colored corolla; ovules 2; pod 1 -seeded.

9. T. microdon, Hook \& Arn. Resembling the last; involucre broader, nearly inclosing the head; its lobes about 3-toothed; calyx smooth.

* * Standard becoming consprcuously inflated and inclosing the rest of the flower; involucre nearly obsolete in No. 12.

10. T. barbigerum, Torr. Somewhat pubescent; stems rather stout, decumbent or ascending, a span high or less; stipules scarious; involucre as broad as the heads, shortly lobed; calyx-tube short, membranaceous; its tceth setaciously awned, plumose, the lower usually exceeding the purple corolla, sometimes 3-parted; pod 2-seeded.

Var. Andrewsii, Gr. A stout villous form, the heads sometimes an inch broad; calyx teeth very long.

11. T. fucatum, Lindl. Smooth; stems stout and succulent, a foot or two high; stipules large and scarious, usually very broad and entire; leaflets obovate, $\frac{1}{2}$ to $1 \frac{1}{2}$ inches long; heads large; involucre broad, deeply cleft; flowers often an inch long, pale rosecolored or purplish; 2-6-seeded.

12. T. depauperatum, Desv. Smooth, low, slender; heads only 3-10-flowered; involucre scarcely more than a scarious ring.

13. T. amplectans, Torr \& Gr. Like the last; the involucre larger. Probably only a variety.

\section{MELIIOTUS, Tourn. SWEET ClOver.}

Flowers as in Trifolium, except that the petals are free from the stamens and decidu. ous. Pod 2-seeded.

1. M. parviflora. Desf. Annual, smooth, erect, often 2 or $3 \mathrm{ft}$. high; leaflets 
mostly cuncate, oblong, obtuse, denticulate, an inch long or less; flowers yellow, a line lung, in slender axillary pedunculate racemes; pedicels a line long.

\section{MEDICAGO, L.}

Characters nearly as the last; style subulate; pod compressed, falcate, incurved or spirally coiled.

1. M. sativa, L. (Lucern, Alfalfa.) Stems erect, 1 to $4 \mathrm{ft}$. high; from a deep perennial root, smooth; leaflets cuneate-oblong or oblanceolate, toothed above; flowers 3 or 4 lines long, racemed; pods numerous, spirally twisted, veined, smooth.

2. M. denticulata, Willd. Bur-Clover. Annual, nearly smooth, prostrate or ascending; leaflets cuneate-obovate or obcordate, toothed above; flowers small, yellow, usually 3 to 8 in an axillary cluster; pods spiral, armed with a double row of hooked prickles.

3. M. lupulina, L. Pubescent, procumbent; flowers vcry small, yellow, in short spikes; pods smooth, reniform, 1-seeded.

\section{HOSACIZIA. Douglas.}

Calyx teeth nearly equal, usually shorter than the tube. Petals free from the stamens, nearly equal; standard ovate or roundish, the claw often remote from the others; wings obovate or oblong; keel somewhat incurved. Style incurved. Pod linear, sessile, severalseeded, partitioned between the seeds. - Herbaceous or rarely suffrutescent; leaves pinnate, 2-many-foliolate; stipules minute and gland-like, rarely scarious or foliaceous; flowers yellow or reddish, in axillary sessile or pedunculate umbels.

The flowers usually change to reddish or reddish-brown in drying. Matured pods are necessary for the determination of species.

§ 1. Pod shortly acute, linear and many-seeded, straight, smooth; seeds suborlicular; flowers and fruit not reflexed; peduncles long; keel broad above mostly obtuse.

Stipules large, foliaceous; villous, viscid.................... stipularis. I Stipules scarious; smooth.

Bract small or none; wings usually white..................... bicolor. 2 Bract 1-3-foliolate, at the umbel; keel and wings purplish............ gracilis. 3

Stipules reduced to blackish glands.

Appressed-pubescent; tall, stout; pod long, smooth.............. grandiflora. 4 Elowers very small, solitary............................ parviflora. 5

§ 2. Pod shortly acute, 3-7-seeded, straight; flowers small, mostly solitary; keel acute; stipules gland-like; villous.

Blade of the standard cordate; leaflets 3 to 5 ; nearly smooth.........II, parviflora. 5 
Flowers peduncled; corolla scarcely exceeding the calyx; leaves nearly

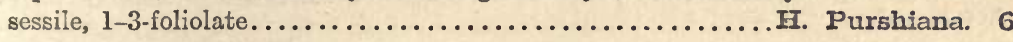

Flowers nearly sessile, not bracteate; corolla larger; leaves petioled, 3-5-foliolate; low. Calyx-teeth about equaling the tube, pod 5 -seeded.............. subpinnata. 7 Teeth much longer than the tube; pod $2-4$-seeded............F. brachycarpa. 8

§ 3. Pod long-attenuate upward, iucurved, pubescent; stipules gland-like; leaflets 3 to \%; seeds 1 or 2; peduncles short or none; flowers and fruit reflexed.

Somewhat woody; nearly smooth; stems angled; leaflets mostly 3 , oblong to linear. Umbels sessile; teeth narrow, erect.................................. 9 Peduncles short or nearly wanting; teeth usually recurved........ H. cytisoides. 10 Peduncles shorter; teeth short and blunt...................... juncea. 11

Very silky-pubescent or tomentose; stems herbaceous: pod pubescent, short; umbe's on short peduncles.

Very pubescent throughout; flowers 3 or 4 lines long ........... tomentosa. 12 Less pubescent; stem smooth; flowers smaller............... H. Heermanni. 13

1. H. stipularis, Benth. Rather tall, stout, two feet high or more, glandular; leaflets 15 to 21 , obovate oblong, acute and mucronate, a half to an inch long; stipules large ovate; often fragrant.

2. If. bicolor, Dougl. Smooth, erect and stout; leaflets 5 to 9 , obovate or oblong, a half to an inch long; stipules rather large; peduncles longer than the leaves, 3-7-flowered, naked or sometimes with a small 1-3-foliolate bract at the summit; flowers nearly sessile yeilow, the wings often white; pod slender nearly 2 inches long.

3. H. gracilis, Benth. Much like the last; usually low and slender, the weak stems a span high or more; umbel with a petioled 1-3-foliolate bract; flowers yellow, keel and wings purplish.

4. I. grandiflora, Benth. Stout, 1 to $5 \mathrm{ft}$. high, more or less appressed silkypubescent; leaflets 5 to 7 on an elongated rachis, 6 to 9 lines long; peduncles elongated; umbel 3-8-flowered, usually subtended by a single leaflet; flowers nearly sessile, 6 to 11 lines long, yellowish or greenish white, often tinged with purple, pod slender, smooth.

5. II. parvillora, Benth. Smooth or nearly so, stems slender, ascending, a span high or less; leaflets 3 to 5 , obovate and very small to narrowly oblong and 6 to 8 lines long; bract 1-3-foliolate; flowers about 2 lines long, yellow.

II. Purshiana, Benth. Silky-villous, rarely smooth, often a foot high or more; leaflets varying from ovato to lanceolate, 3 to 9 lines long; peduncles usually exceeding the leaves; the solitary flowers 2 or 3 lines long.

7. II. subpinnata, Torr. \&.Gr. Villous or smooth, decumbent, a span high or less; leaflets half an inch long or less; flowers 3 or 4 lines long; pod linear oblong; about 5 -sceded. 
8. II. brachycarpa, Benth. Resembling the last; softly villous; pod villous, 2-4-seeded.

9. II. glabra, Torr. Very nearly smooth; stems woody at base, 2 to $8 \mathrm{ft}$. long, erect or decumbent; leaflets oblong to linear-oblong, 3 to 6 lines long; umbels numerous, sessile; flowers 3 or 4 lines long; seeds 2.

10. H. cytisoides, Benth. Resembling the last; peduncles equaling or exceeding the leaves, or sometimes very short, usually with a 1-3-foliolate bract at the top; calyxteeth attenuate, mostly recurved.

11. II. juncea, Benth. Somewhat shrubby, erect; leaflets obovate to oblong, 2 to 4 lines long; umbels on very short peduncles or sessile; flowers about 3 lines long; calyx 2 lines long or less; teeth short and blunt.

12. FI. tomentosa, Hiook \& Arn. Very pubescent, weak and flexuose, prostrate or ascending, a foot or more long; leaflets 5 to 7, cuneate-oblong to obovate, acute, 3 to 6 lines long; umbels on short bracteolate peduncles, or the uppermost sessile; flowers 3 or 4 lines long; alyx half as long or more, very villous.

13. II. Heermannii, Durand \& Hilgard. Less pubescent, much branched and spreading; leaflets smaller; flowers smaller.

\section{PGORAIEA, I.}

Calyx lobes nearly equal, or the lower one longer; the two upper often connate. Keel broal and obtuse above, united with the wings. Stamens diadelphous or monadelphous. Pod orate, indehiscent, 1 -seeded, thick, sessile. Perennial herbs punctate with dark glandular dots. Leaves pinnately 3 -foliolate. Stipules free.

* Stems prostrate, creeping; leaves orbicular.

1. P. orbicularis, Lindl. Petioles 6 to 12 inches long; the leaflets 2 to 4 inches across, slightly cuneate at the base; peduncles equaling or exceeding the leaves, bearing a close villous spike of large flowers; the lower tcoth of the calyx much the longest and about equaling the purplish corolla; stamens diadelphous.

* * Stems erect.

2. P. strobilina, Hook \& Arn. Two or three feet high; petioles 3 or 4 inches long; leaflets rombic ovate, softly pubescent beneath, about 2 inches long; stipules large, membranaceous; flowers in short oblong spikes, smaller than the last; stamens monadel. phous.

3. P. macrostachya, D C. Three to even twelve feet high; leaflets ovate-lanceolate, an inch or two long or more; peduncles much exceeding the leaves; spikes cylin. drical, silky villous, the hairs often blackish; the lower tooth of the calyx but little the longest, scarcely equaling the purple petals; tenth stamen nearly free.

4. P. physodes, Dougl. A foot or two high, nearly smooth, slender; leaflets 
orate, mostly acute, about an inch long; the white or purplish flowers in short, closo racemes; ealyx at length inflated; stamens monadelphous.

\section{AMORPHA, L.}

Calyx obconical, nearly equally 5-toothed; wings and keel wanting; the standard erect, folded together. Stamens slightly united at the base, exserted. Pod 1-2-seeded. Shrubs, glandular-punctate; the unequally pinnate leaves with the leaflets stipellate; flowers purple or violet in dense clustered terminal spikes.

1. A. Californica, Nutt. Three to eight feet high, puberulent; leaflets 5 to 7 pairs, oblong-elliptical, obtuse, mucronulate, an inch long; spikes 1 to 6 inches long.

\section{GIYCYRRHIZA, L. LIQUORICE.}

Flowers nearly as in Astragalus. Erect perennial herbs, glandular viscid; leaves unequally pinnate; stipules deciduous; flowers in dense axillary pedunculate spikes; root large and sweet.

1. G. lepidota, Nutt., var. glutinosa, Wat. Two or three feet high; flowers yellowish white or pinkish; the short peduncles covered with stout viscid hairs. Rare; on water courses.

\section{ASTrRagaLUS, Tourn. RATTLE-WEed.}

Calyx 5-toothed. Corolla and its slender clawed petals usually narrow; keel obtuse. Stamens diadelphous. Legume very various, commonly turgid or inflated, one or both sutures usually projecting inward, frequently so much as to divide the cell into two. Seeds few or many on slender stalks, generally small for the size of the pod. Herbs, or a few woody at the base; with unequally pinnate leaves, and small flowers, chicfly in simple spikes or racemes from the axils.

A vast genus of five or six hundred species; about fifty on the Pacific coast. The fruit is needed for the determination of the species.

\section{* Root annual; pod not inflated, 2-celled.}

Pod wrinkled, 2-lobed, 2-seeded........................ didymocarpus. I Pod not wrinkled, several-seeded............................ tener. 2

\section{* * Root perennial; pod bladdery-inflated, 1-celled.}

Stipe a little exceeding the calyx; pod with pointed ends.......... oxyphysus. 3 Stipe much exceeding the calyx; pod obtuse, one-sided........... leucophyllus. 4

Stipe, none; pod large and very bladdery, many seeded; leaflets mostly in many pairs; snike or raceme many flowered.

Stipules distinct; pod rather firm walled..$\ldots \ldots \ldots \ldots \ldots \ldots \ldots \ldots$. Crotalariæ. 5

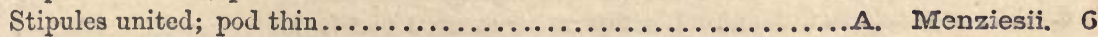
Stipules membranaceous; corolla yellowish................. Douglasii. 7 
1. A. didymocarpus, Hook. \& Arn. Slender from 3 inches to a foot high; leafiets 9 to 15, narrowly oblong to linear and more or less cuneate, deeply notehed at the apex; small flowers white and violet; pod not over two lines long, short uval and deeply 2-lobed lengthwise.

2. A. tener. Gr. A span or so in hight; leaflets similar to the last, not so deeply notched or entire; pod about half an inch long, 5-10-seeded; corolla 4 or 5 lines lon: bright violet to pale and violet-tipped.

3. A. oxyphysus, Gr. Canescent with very soft silky pubescence; stem erect, 2 to $3 \mathrm{ft}$. high; leaflets oblong an inch or less in length; peduncles much exceeding the leaves; corolla greenish-white $S$ lines long; bladdery pod acuminate and tapering into the recurved stipe which a little exceeds the calyx.

4. A. leucophyllus, Torr. \& Gr. Less canescent than the last; flowers about half an inch long; corolla yellowish-white; the thin pod unequal-sided, an inch and a half long on a filiform pubescent stipe of almost equal length.

5. A. Crotalariæ, Gr., var. virgatus, Gr. Smooth or the young parts villous; stems 2 or $3 \mathrm{ft}$. high, stout; stipules scarious, triangular or subulate, distinct; peduncles elongated; racemes virgate and loose, 4 to 10 inches long; the white flowers soon deflexed.

6. A. Menziesii, Gr. Villous with whitish hairs or soon green and almost smooth; stems sometimes decumbent, 1 to $4 \mathrm{ft}$. high; the lower stipules united opposite the leaf; infloreseence similar to the last but more dense; pod larger (an inch and a half or more long) and more bladdery.

7. A. Douglasii, Gr. Cinereous-puberulent, almost smooth in age, stems ascending, a foot or so in height; leaflets in numerous pairs; linear or linear-oblong, 4 to 9 lines long: spike, half to an inch long; 10-20-flowered; pod gibbous-ovoid, $1 \frac{1}{2}$ to 2 inches long.

\section{2 in vicia, Tourn. Vetch. Tare.}

Calyx 5-toothed or cleft, usually unequally. Wings adherent to the middle of the short keel. Stamens diadelphous or nearly so. Style filiform, inflexed, the apex sur. 'ounded by hairs or hairy upon the back. Pod flat 2-valved, shortly stipitate. Herbs, with angular stems climbing by branched tendrils terminating the pinnate leaves; leaflets entire or toothed at the apex; stipules semi-sagittate; flowers solitary or in loose axillary racemes.

\section{* Perennials; flowers in pedunculate racemes.}

1. V. gigantea, Hook. Stout and tall, climbing several feet high; leaflets 10 to 15 pairs, oblong, obtuse, mucronate, an inch or two long; stipules large; peduncles 5-18-flowered; corolla 6 or 7 lines long, pale purple; pod broadly oblong, $1 \frac{1}{2}$ inches long or more, smooth 3-4-seeded.

The seeds are large and edible; blackens in drying.

2. V. Americana, Muhl. Usually rather stout, 1 to $4 \mathrm{ft}$. high, smooth: leaflets 4 to 8 pairs, variable, linear to ovate-oblong, truncate to acute, $\frac{1}{2}$ to 2 inches long; peclun. 
cles 4-8-flowered; flowers purplish, 6 to 9 lines long; style very villous at the top; pods an inch long or more, 3-6-seeded.

Var. truncata, Brewer. Somewhat pubescent; leaflets truncate and often 3-5.toothed at the apex.

Var. linearis, Watson. Leaves all linear. Only the varieties are likely to be found.

$$
\text { * * Slender annuals; flowers mostly solitary. }
$$

3. V. exigua, Nutt. A span to two feet high, somewhat pubescent; leaflets about 4 pairs, linear, acute, a half to an inch long; peduncles usually short, rarely 2-flowered; flowers 3 lines long, purplish; pod about 6-seeded.

4. V. sativa, I. Rather stout, somewhat pubescent; leaflets 5 or 6 pairs, obovateoblong to linear, retuse, long-mucronate; flowers nearly sessile, an inch long, violetpurple. - The common tare of Europe. Introduced.

\section{IATHYRUS, I.}

Style dorsally flattened toward the top, and usually twisted, hairy on the inner side. Peduncles usually equaling or exceeding the leaves and several flowered.

* Rachis of the leaves tendril bearing; pod sessile; racemes several flowered.

1. L. venosus, Muhl., var. Californicus, Watson. Very stout, several feet high; stems often strongly winged; leaflets oblong-ovate, acute; flowers nearly or quite an inch long, purple; pod about 2 inches long.

2. L. vestitus, Nutt. Slender, a foot to 6 or 10 feet high; stems not winged; stipules narrow, often small; flowers pale rose-color or violet, usually 7 to 10 lines long; uvary pubescent.

3. I. palustris, I. Slender, a foot or two high; stem often winged; leaflets narrowly oblong to linear, acute, an inch or two long; flowers purplish, half an inch long.

Var. myrtifolius, Gr. Stipules broader; leaflets ovate to oblong, shorter.

* Rachis of the leaves not tendril bearing, or rarely so; pod shortly stiputate, peduncles long; 2-6-flowered.

4. I. littoralis, Endl. Densely silky-villous throughout; stems numerous, from creeping root-stocks, stout, decumbent or ascending, $\frac{1}{2}$ to $2 \mathrm{ft}$. high; leaflets 1 to 3 pairs, with a small linear or oblong terminal one; calyx teeth nearly equal; standard bright purple, 6 to 8 lines long, exceeding the paler wings and keel; pod villous, an inch long.

\section{ORDER 21. ROSACEAE.}

Herbs, shrubs or trees, $\pi$ ith alternate leaves, usually evident stipules, mostly numerous stamens borne on the calyx; distinct free pistils from one to many, or in one sub. 
order few and coherent with each other and adherent to the calyx forming a 2-several celled inferior ovary.

Nearly all the cultivated fruits of the temperate zones belong to this order.

\section{SUB-ORDER 1. AMYGDALEZS.}

Carpels solitary, or rarely 5, becoming drupes, entirely free from the calyx, this or its lobes deciduous.—Trees or shrubs with bark and seeds tasting and smelling like those of the peach or cherry. Stipules few, deciduous.

Flowers perfect; carpel solitary .............................. Prunus. I Flowers not all perfect; carpels $5 \ldots \ldots \ldots \ldots \ldots \ldots \ldots \ldots \ldots \ldots \ldots$ Nuttallia. 2

\section{SUb-order 2. ROSACEE Proper.}

Carpels free from the persistent calyx becoming akenes, follicles or berries.

§ 1. Carpels few, becoming follicles; calyx open.

Shrubs; follicles 2 to 8 ; flowers minute, in panicles................... Spiræa. 3 Shrubs; follicles 1 to 5 ; flowers larger, in corymbs................. Neiliia. 4

§2. Carpels several or numerous, on a spongy receptacle, forming a compound berry............................................. Rubus. 5

§3. Carpels one or many, becoming dry akenes.

Shrubs; solitary, axillary apetalous flowers.................. Cercocarpus. 6 Herbs; carpels many, on a fleshy receptacle.................... Fragaria. 7 Herbs; carpels many, on a dry receptacle-

Stamens 20 to $25 \ldots \ldots \ldots \ldots \ldots \ldots \ldots \ldots \ldots \ldots \ldots \ldots \ldots \ldots \ldots \ldots \ldots$ Potentilla. 8

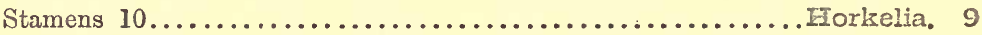

Shrub: heath-like, with subulate fascicled leaves...............Adenostoma. 10 § 4. Erect shrubs; showy flowers............................Rosa. 11

\section{SUB-ORDER 3. POMIER.}

Carpels 2 to 5 , inclosed in and mostly adnate to the fleshy calyx-tube, in fruit becoming a berry-like pome. Trees or shrubs, with free stipules.

Stamens 10, in pairs; fruit red..........................teteromeles. I2 Stamens 20 ; fruit black.............................melanchier. I3

1. PRUNUS, Tourn. Plem, Cherry, Etc.

Calyx 5-cleft, deciduous. Petals 5, spreading. Stamens 15 to 25, inserted with the 
petals. Ovary solitary, free, with two pendulous ovules; style terminal. Fruit a drupe, with usually a long stone containing one seed.

Deciduous; flowers white.

Corymbose; appearing before or with the leaves............... emarginata. I Racemose; appearing after the leaves........................ demissa. 2 Evergreen; leafless racemes axillary ....................... ilicifolia. 3

1. P. emarginata, Walp. Four to eight feet high, with bark like the ordinary cherry tree, and chestnut-brown very slender branches; leaves oblong-obovate to oblanceolate, obtuse, narrowed to a short petiole; corymb 6-12-flowered, shorter than the leaves; flowers 4 to 6 lines broad; fruit globose, black; stone with a thick grooved ridge upon one side.

2. P. clemissa. Walp. (Wrld Cherry.) Slender, 2 to $12 \mathrm{ft}$. high; leaves ovate to oblong-ovate, abruptly acuminate, mostly rounded or somewhat cordate at the base; racemes 3 or 4 inches long; fruit purplish-black or red, edible but astringent.

3. P. ilicifolia, Walp. (Evergreen Cherry.) Much branched, 8 to $12 \mathrm{ft}$. high, with grayish-brown bark; leaves thick and rigid, shining above, broadly ovate to ovatelanceolate, spinosely toothed; flowers small in racemes $\frac{1}{2}$ to 2 inches long; fruit red or dark purple, half an inch or more thick.

\section{INUTtaIIIA, Torr. \& Gr. Oso BerRy.}

Petals 5, broadly spatulate, erect. Stamens 15 in two rows, 10 inserted with the petals, and 5 lower down upon the disk lining the calyx-tube, filaments very short, the lower declined. Carpels 5, inserted on the persistent base of the calyx-tube, free, smooth.

1. IN. cerasiformis, Torr. \& Gr. A shrub 2 to $15 \mathrm{ft}$. high; leaves rather broadly oblanceolate, short petioled; racemes of greenish white flowers, appearing with the branchlets from the same bud; drupes blue-black; with a slight furrow on the inner side, 6 to 8 lines long, bitter.

\section{SPIRAEA, L.}

Calyx persistent, 5-lobed. Petals 5, rounded, necrly sessile. Stamens 20 or more, inserted with the petals. Carpels distinct and sessile, becoming several-seeded follicles.

1. S. discolor, Pursh. A diffuse shrub, $4 \mathrm{ft}$. high or more with grayish brown bark, pubescent; leaves broadly ovate, truncate at base or cuneate into a slender petiole, pinnately toothed or lobed, the lobes often dentate; panicle of dingy white flowers much branched, tomentose.

Var. ariæfolia, Wat. Taller, 5 to $15 \mathrm{ft}$. high, leaves 2 or 3 inches long, panicle larger.

Var. dumosa. Wat. Only 1 or $2 \mathrm{ft}$. high, leaves an inch long or less, cuneate into a short margined petiole.

\section{NEIIIIA, Don. NINE-Bark.}

Carpels 1 to 5, inflated and divergent; flowers large, white, in simple corymbs. 
1. I. opulifolia, Benth. \& Hook. A shrub 3 to $10 \mathrm{ft}$. high, with slender spreading nr recurved branches and ash-colored shreddy bark; leaves ovate to cordate, 3-lobed and toothed, 1 to 3 inches long.

\section{RUBUS, L.}

Calyx persistent 5-lobed. Petals 5, conspicuous. Stamens numerous. Carpels numer ous, on a convex receptacle, becoming small globose l-seeded drupes, forming a com. pound berry. - Fruit edible.

\section{$\S 1$. Fruit with a bloom, separating from the receptacle when ripe.}

Leares simple, palmately lobed; stem soft, woody................ Nutkanus. I Leaves 3 -foliolate, or on the flowering branches simple, rarely 5 -foliolate; stems soft, woody, prickly-

Flowers large, red. .spectabilis.

Flowers white................................leucodermis.

Stems herbaceous, trailing unarmed.......................... pedatus. 4

§ 2. Fruit persistent, black and shining; stems prickly, flowers white......... ursinus. 5

1. R. Nutkanus, Moc. (Thrmble-serry.) Stems erect, 3 to $8 \mathrm{ft}$. high; older bark shreddy, no prickles; leaves 4 to 12 inches broad; flowers large white, rarely rose-colored, an inch or more across; fruit red, large.

2. R. spectabilis, Pursh. (Salmon-Berry.) Stems 5 to $10 \mathrm{ft}$. high, similar to the last, but armed with a few prickles. Distinguished by its large red fluwers and cylindrical-ovoid yellow or purplish berries.

Var. Menziesii, Wat. Densely tomentose and silky.

3. R. leucodermis, Dougl. (Raspberry.) May be known by its leaflets, white. tomentose beneath, prickly stem, white flowers, and its yellowish red white-bloomed fruit.

4. R. pedatus, Smith. Stems slender pubescent; leaflets cuneate-obovate, an inch or less in length; flowers white; the at length reflexed sepals exceeding the petals; berry of only 3 to 6 large red pulpy drupclets.

5. R. ursinus, Cham. \& Schl. (Blackberry.) Stems weak or trailing, 5 to $20 \mathrm{ft}$. long; fruit oblong.

\section{CERCOCARPUS, HBK.}

Calyx narrow, tubular, the campanulate 5-lobed limb deciduous. Petals none. Stamens in 2 or 3 rows on the limb of the calyx. Carpels solitary. Fruit a villous akene, included in the enlarged calyx-tube, tailed with the elongated exserted plumose twisted style.

Evergreen shrubs or trees. C. ledifolius, Nutt. is the Mounina MINIOGANY of the Sierra Nevada. The following is found in the Coast Range. 
1. C. parvifolius, Nutt. A shrub 2 to $10 \mathrm{ft}$. high, or rarely a trec, branching from a thick base. Tails of the fruit often 4 inches long.

\section{FRAGARIA. Tourn. STRAWBERry.}

Calyx persistent; limb 5-toothed, with 5 alternate bractlets. Petals white, spreading. Stamens in one row. Carpels numerous, smooth; styles lateral short. Receptacle much enlarged in fruit, conical, scarlet, bearing the small akenes on its surface.

1. F. Chilensis, Ehrh. Densely villous, with silky hairs; leaflets thick, smooth above; flowers often an inch broad; fruit ovate; akenes deeply pitted.

2. F. Californica, Cham. \& Schl. Somewhat villous; leaves thin, veiny; fruit small; akenes not in pits.

\section{POTENTILLA, L.}

Calyx as in Fragaria. Petals yellow, rarely white. Stamens 20 to 50, marginal in 1 to 3 rows. Carpels numerous. Akenes small, on a dry receptacle.

1. P. glandulosa, Lindl. Perennial, erect, a foot or more high; leaves pinnate; leaflets 5 to 9 , rounded, ovate, coarsely serrate; flowers cymose; calyx 4 to 6 lines long, usually villous, with coarse hairs; bractlets shorter than the lobes; petals not exceeding the calyx; stamens 25 in one row.

2. P. Anserina, L. (SrLver-WEed.) White tomentose and sillky-villous leaves, all radical, often a foot long or more; leaflets 3 to 10 pairs, with smaller ones interposed, oblong, sharply serrate, tomentose, at lcast beneath; flowers yellow, solitary, on scapelike peduncles.

\section{HORKELIA, Cham. \& Schl.}

Petals obovate to linear, often clawed, white or pink. Stamens 10, in two rows; filaments more or less dilated; those opposite to the sepals broadest. Flowers cymose.

* Bractlets nearly as broad as the calyx-lobes.

1. II. Californica, Cham. \& Schl. Glandular-pubescent; stems a foot high or more; leaflets 5 to 10 pairs, 3 to 8 lines long; calyx about equaling the spatulate petals.

Var. sericea, Gr. Canescent throughout, with a dense, sillky pubescence; leaflets larger.

* Bractlets much narrower than the calyx-lobes.

2. II. tenuiloba, Gr. Canescently villous, a foot high; leaflets 8 to 12 pairs, deeply incised, 2 or 3 lines long.

3. I. Bolanderi, Gr. Densely hoary-pubescent, cespitose, the stems 3 or 4 inches high, the numerous leaflets minute, with rounded lobes.

\section{ADENOSTOMA, Hook \& Arn. Chamiso.}

Calyx persistent, 5-lobed; tube obconical, 10-ribbed; lobes membranaccous, broad. 
Petals 5, orbicular, spreading. Stamens 10 to 15, usually 2 or 3 together between the petals. Fruit a membranaceous akene, included in the indurated calyx-tube. - Evergreen shrubs, somewhat resinous; flowers small, white, in terminal, racemose panicles.

1. A. fasciculatum, Hook \& Arn, A diffusely branching shrub, 2 to $20 \mathrm{ft}$. high, with reddish virgate branches and grayish shreddy bark; leaves fascicled, linear subulate, 2 to 4 lines long, usually channeled on one side, smooth.

Alchemilla arvensis, Scop., belongs here. Its minute, greenish, apetalous flowers are fascicled in the axils of the small leaves and inclosed by the cleft stipules. A small under herb, growing on sandy hillsides.

Acæna trifida, R. \& Pav. Is another apetalous herb, with silky, villous leaves and stem rising from a woody caudex; 3 to 15 inches high. The leaves are pinnate, the leaflets pinnately cleft into 3 to 7 segments. The greenish flowers with purple stamens are in a crowded terminal spike. Habitat similar to the last.

\section{ROSA. Tourn. Rose.}

It is not necessary to here characterize this well-known genus.

1. R. Californica, Cham. \& Schl. Erect, 2 to $8 \mathrm{ft}$. high, sparingly armed with usually recurved prickles, tomentose; leaflets 2 or 3 pairs; calyx lobes tomentose, often glandular leafy; petals 6 to 9 lines long; fruit globose.

2. R. gymnocarpa, Nutt. Slender, 1 to $4 \mathrm{ft}$. high, armed with straight slender prickles or unarmed, smooth; leaflets 2 to 4 pairs, glandular; flowers solitary, rarely 2 or 3 , rarely an inch in diameter; calyx lobes at length deciduous; fruit small, ovate or pear. shaped.

\section{HETEROMELES, J. Rœmer. PHotinia.}

Calyx 5-parted. Petals 5, spreading. Stamens in pairs, opposite the calyx-tecth. Fruit red, berry-like. An evergreen shrub or small tree, with coriaceous, simple, sharply serrate leaves. Flowers white in terminal panicles.

1. I. arbutifolia, Rœm. Leaves dark green above, lighter beneath, narrowly to ohlong lanceolate, acute at each end, 2 to 4 inches long, on short petioles, slightly revolute margins; fruit 2 or 3 lines in diameter.

Pirus rivularis, Dougl., the Oregon Crab-Apple, may be found in Sonoma County.

\section{AMELANCEIER, Med. SERVICE-BERRY.}

Calyx-tube eampanulate; the limb 5-parted, persistent. Petals 5, oblong, ascending. Stamens 20, short. Carpels 3 to 5 inferior, becoming membranaceous and partially 2 . celled; styles united below or distinct. Fruit berry like, globose._Shrubs or small trees; leaves simple, serrate; flowers white, racemose; fruit purplish, edible.

1. A. alnifolia, Nutt. A shrub 3 to $8 \mathrm{ft}$. high; leaves broadly ovate, sometimes corlate at the base, serrate only toward the summit, $\frac{1}{2}$ to $1 \frac{1}{2}$ inches long. 
Order CALYCANTHACEza, is represented by Calycantlus occidentalis, Ilook. \& Arn., an erect shrub 6 to $12 \mathrm{ft}$. high, with opposite entire lanceolate leaves, 3 to 6 inches long and large solitary livid or purplish red flowers; sepals and petals numerous, linear-spatulate. The common name of the Eastern species-Sweet-Scented Shrub-is scarcely applicable to our species.

\section{ORDER 22. SAXIFRAGACE正.}

Herbs, shrubs, or small trees, distinguished from Rosacece by albuminous seeds; usually by definite stamens, not more than twice the number of the calyx-lobes; commonly by the want of stipules; sometimes by the leaves being opposite; and in most by the partial or complete union of the 2 to 5 carpels into a compound ovary. Seeds usually indefinite or numerous. Petals and stamens on the calyx. Styles inclined to be distinct. Only the Hydrangiece have many stamens.

Tribe 1. SAXIFRAGEZE. Herbs, leaves mostly alternate and without distinct stipules. Styles or tips of the carpels distinct. Fruit capsular or follicular.

* Ovary with 2 or rarely more cells, or of as many distinct carpels.

Stamens 10, rarely more................................ Saxifraga. I Stamens 5 . Boylinia. 2

* * Ovary 1-celled.

Stamens 10, included. Tellima. 3

Stamens 10, exserted.....................................Tiarella. 4

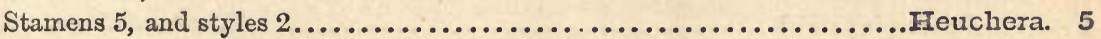

Tribe 2. HYDRANGIEZs. Shrubs, leaves opposite, simple, no stipules. Fruit capsular.

A tall shrub. Large white flowers........................ Philadelphus. 6 Low, scarcely shrubly. Small flowers....................Whipplea. 7

Tribe 3. GROSSULARIEZE. Shrubs, leaves alternate with stipules adnate to the petiole or wanting. Fruit a berry.

Calyx-tube adnate to the ovary. Ribes. 8

\section{SAXIFRAGA, L. SAXIFRAGE.}

Calyx 5-lobed, free, or its tube coherent with the lower part of the ovary. Petals 5. Fruit of 2 follicles, or a 2-lobed capsule.-In our species stemless; flowers white.

1. S. Virginiensis, Michx. Leaves thickish, oblong-ovate to spatulate-obovate, coarsely toothed or almost entire, an inch or two long and the margined petiole often as long; scape viscid pubeseent, 4 to 12 inches high, at length lonsely many flowered in a paniculate cyme; flowers, small white. 
2. S. integrifolia, Hooker. Larger; leaves shorter petioled; flowers in a thyrsiform panicle; calyx lobes reflexed.

3. S. Mertensiana, Bong. Scape and leaves from a scaly granulate bulb; leaves rounded and cordate on long naked petioles; crenately or incisely lobed, the lobes often 3 -toothed at the end; 2 to 4 inches across; calyx free.

\section{EOYIINIA, Nutt.}

Calyx 5-lobed, adherent to the ovary. Petals 5, entire, closed. Stamens alternating with the petals. Ovary and eapst:le 2-celled.-Perennial herbs, with ereeping rootstocks, simple leafy stems; the leaves alternate, round-reniform, palmately lobed and incised or toothed, the teeth with callous-glandular tips, and the petioles mostly with stipule-like appendages at the base.

1. B. oocidentalis, Torr. \& Gr. Smoothish, or with some rusty hairs; a foot or two high; leaves thin-membranaceous, 3-7-lobed; petals white, 2 or 3 lines long.

\section{TELIIMA, R. Br.}

Calyx campanulate or turbinate, 5-lobed; the base coherent with the lower part of the ovary. Petals 5, inserted in the throat or sinuses of the calyx, laciniate-pinnatifid, 3-7-lobed, or entire. Stamens 10, short. Ovary short, 1-celled, with 2 or 3 parietal placentæ; styles 2 or 3 , very short; stigmas capitate. Capsule conical, slightly 2-3beaked.-Perennials, with round-cordate and toothed or palmately divided chiefly alternate leaves, few on simple stems, their petioles with stipule-like dilations at the base, and the flowers in a simple terminal raceme; petals white or pinkish.

Petals laciniate-pinnatifid ........................... grandiflora. I Petals entire, spatulate-obovate......................... Cymbalaria. 2 Petals entire; pedicels very short........................ Bolanderi. 3 Petals obtusely 3 -lobed $\ldots \ldots \ldots \ldots \ldots \ldots \ldots \ldots \ldots \ldots \ldots \ldots$. . heterophylla. 4 Petals acutely 3 -lobed $\ldots \ldots \ldots \ldots \ldots \ldots \ldots \ldots \ldots \ldots \ldots \ldots \ldots \ldots \ldots \ldots \ldots \ldots \ldots \ldots \ldots$ affinis. 5

1. T. grandiflora, Dougl. A foot or more high, from short stout tufted rootstocks, hirsute or pubescent; leaves lobed, 2 to 4 inches in diameter; flowers dull-colored.

2. T. Cymbalaria, Gr. Stem or scape filiform, 4 to 12 inches high, bearing mostly a pair of opposite 3-lobed or parted leaves; radical leaves somewhat 3-5-lobed, half an inch across, flowers few and slender pediceled, white.

3. I. Bolanderi, Gr. Stems a foot or two high, 1-4-leaved; radical and lower leaves lobed, the upper 3-5-parted; petals rarely with a small tooth on each side, white.

4. T. heterophylla, Hook. \& Arn. Stems slender, a foot or less in height 1-3leaved; leaves similar to the last, but smaller; flowers fewer and smaller, sometimes flesh-colored.

5. T. affinis, Gr. Rougher-pubescent; stem and leaves similar to the last; calyx lensely rough glandular-pubescent; petals 4 or 5 lines long, white or flesh-colorec?. 


\section{TIARELLA, I.}

Distinguished by the minute, slender petals, long exserted stamens, and the very unequal horns of the 2-carpeled ovary.

1. T. uniioliata, Hook. Somewhat hairy; flowering stems 4 to 15 inches high, 1-3leaved; leaves thin, cordate, 3-5-lobed, crenate-toothed; flowers small, panicled.

\section{HEUCHERA, L. ALUM-ROOT.}

Calyx tube coherent with the lower half of the ovary. Petals small, entire, clawed. Ovary more or less 2-beaked; the beaks tapering into either filiform long, or subulate shorter styles.-Herbs with small, dull-colored paniculate flowers. Scarious stipules adnate or distinct. Leaves round-cordate, obtusely lobed, crenate-toothed.

1. H. micrantha, Dougl. Scape, or few leaved flowering stems, a foot or two high; leaves 2 to 4 inches in diameter; calyx acute at the base, lobes erect; styles slender.

2. Ir. pilosissima, Fisch. \& Mey. Very villous-pubescent or hirsute, with viscid hairs; calyx rounded or obtuse at the base, the broad, short lobes incurving, densely hairy; styles short.

\section{PHilladelphus, L. Mock Orange.}

Calyx adhering to the ovary nearly or quite to the summit, persistent. Petals 4 or 5, large, obovate or roundish. Stamens 20 to 40 . Styles 3 to 5 , united at the base or nearly to the top. - Shrubs with opposite leaves and showy white flowers.

1. P. Gordonianus, Lindl. Six to twelve feet high; leaves ovate to oblong-ovate, mostly coarsly-serrate, 2 to 4 inches long; flowers in loose clusters, which are leafy at the base; petals frequently an inch long.

\section{WHIPPLEA, Torr.}

Calyx lobes thin, white or whitish. Petals ovate or oblong. Ovary 3 to b-celled. Sty'es distinct, subulate. - Small, trailing or diffuse, ours half shrubby plants, with opposite, short petioled, 3-ribbed leaves, no stipules and small white cymose-clustered flowers; peduncles naked, terminal. .

1. W. modesta, Torr. Leaves membranaceous, ovate or oval, obtusely few-toothed or entire, an inch or less long. Flower 2 lines long, clusters close-flowered, fragrant.

\section{RIBES, L.}

Calyx tube adnate to the globose ovary and extended beyond it, the limb commonly petaloid. Petals erect, mostly smaller than the calyx-lobes. Stamens alternate with the petals. Berry crowned by the withered remains of the flower. - Shrubs with alternate palmately lobed leaves. 
§ 1. Thorny under the fascicles. Gooseberries.

Berry prickly ................................... Menziesii. I

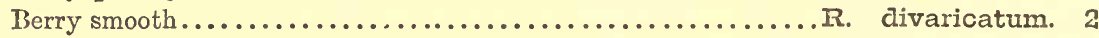
Derry dry; flowers large, bright-red..................... speciosum. 3

§ 2. Thornless and prickless. Currants.

Flowers rose-red to white............................ sanguineum. 4

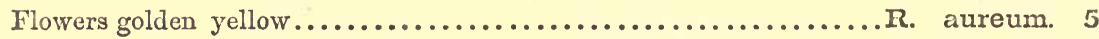

1. R. Menziesii, Pursh. Calyx about half an inch long, purplish red; its oblong lobes spreading or recurved, longer than the funnelform tube, hardly longer than the atamens which surpass the whitish petals; berry thickly covered with prickles.

2. R. divaricatum, Dougl. Flowers one-third of an inch long; calyx livid-purplish or greenish-white; its lobes about twice as long as the fan-shapcd white petals, these only one-third as long as the stamens and villous 2-cleft style.

3. R. speciosum, Pursh. Very tall; flowers 2 to 5 on a bristly-glandular peduncle, drooping, fuchsia-like, almost an inch long and stamens as much longer.

4. R. sanguineum, Pursh. Racemes drooping, many flowered; calyx prolonged beyond the ovary into a campanulate tube 2 or 3 lines long, about equaling the lobes. Runs into indefinite varieties.

5. R. aureum, Pursh. Flowers golden yellow, spicy-fragrant, in 5-10-flowered, leafy-bracted racemes.

\section{OrDER 23. CRASSUIACEZF.}

Succulent or fleshy plants, with completely symmetrical as well as regular flowers. Parts of the flower each 4 to 7; stamens twice as many. Petals distinct.... Sedum. I Petals somewhat united.................................Cotyledon. 2

\section{SEDUM, L. STONE-Crop.}

Sepals 4 or 5 united at the base. Carpels distinct or rarely connate at the base.

1. S. spathulifolium, Hook. Stems ascending from a branched rooting caudex, 4 to 6 inches high; leaves obovate or spatulate, flat, 6 to 10 lines long; flowers secund in a forked cyme, nearly sessile, 3 lines long; petals yellow, lanceolate acute.

\section{COTYLEDON, L.}

Petals united into a 5-lobed pitcher-shaped or cylindrical corolla. Stamens 10, in. serted on the corolla-tube. Carpels usually distinct.

1. C. farinosa, Benth. \& Hook. Acaulescent, more or less mealy-pulverulent; rosulate leaves lanceolate, acuminate, the larger ones 2 to 4 inches long; flowering branches a span high with scattered broadly ovate to lanceolate clasping leaves. Flowers yellow. 
2. C. crasitosa, Hawworth. Similar to the last; smooth glaucons-green; flowering branches 6 to 12 inches high, with broadly triangular-ovate clasping leaves. The most common species.

TILLIEA MINIMA, Miers., a small herb 1 to 3 inches high with clusters of minute white flowers in the axils of the opposite leaves is a common under-herb in moist places; as is also T. angustifolia, Nutt., only an inch high with solitary flowers.

ORDER LYTIRACEZ is represented by Lythrum alatum, Pursh., var. linearifolium, Gr. An herb a foot or two high with angled stemes and small deep purple 6-petaled flowers solitary in the axils of the entire sessile leaves.

\section{ORDER 24. ONAGRACEFF.}

Herbs (snrubby exotics), with the parts of the flowers in fours, the calyx tube adnate to the ovary, the petals borne on its throat, and the stamens as many or twice as many. Style always single.

Aquatic stems creeping...................................Jussiæa. I

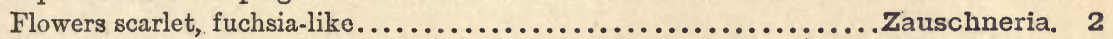

Flowers small, purplish, leaves mostly opposite................... Epilobium. 3

Anthers attached near the center.......................... Cnothera. 4

Flowers purple, calyx lobes reflexed................................. 5

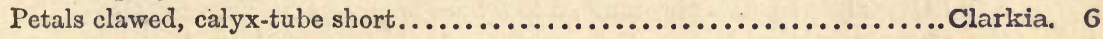

Petals clawed, calyx-tube filiform....................... Eucharidium. 7

Flowers purple in leafy spikes............................. Boisduvalia. 8

Flowers minute, white, parts in twos............................... 9

\section{JUSSIrA, I.}

The 4 to 6 herbaceous lobes of the calyx persistent. Petals as many, obovate, spreading, yellow. Stamens twice as many. Capsule clavate.

1. J. repens, L., Var. Californica, Wat. Characterized sufficiently by its creeping stems and its solitary axillary flowers nearly an inch in diameter.

\section{ZAUßCFNERIA, Presl.}

Tube of the calyx much prolonged beyond the linear ovary, colored, the 4-lobed limb with 8 small deciduous scales, 4 erect and 4 deflexed. Stamens 8 , exserted.

1. Z. Californica, Presl. The scarlet fuchsia-like flowers over an inch long cannot be mistaken.

\section{EPILOBIUM, L. WILLOW-HERB.}

The seeds tufted with silky hairs in linear 4-sided, 4-valved capsules best mark this difficult genus. 


\section{GNOTIERA, L.}

Calyx tube more or less prolonged beyond the ovary; segments reflexed. Petals 4; in our species yellow. Stamens 8, equal, or those opposite to the petals shorter. Stylo filiform; stigma 4-lobed or capitate. (See ADDexda.)

* Acaulescent. Calyx-tube filiform above the under-ground ovary.

Leaves ovate to lanceolate............................. ovata. I Leaves linear................................... graciliflora. 2

* * Caulescent. Calyx-tube obconic; capsule sessile, linear.

Leaves thick; flowers small; capsule thick............... cheiranthifolia. 3 Flowers large; petals with a spot at the base................. bistorta. 4

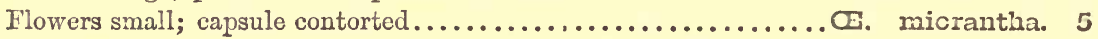

Slender, leafy annuals; leaves linear; flowers small; capsule narrowly linear. Flowers rarely reddening. ........................... dentata. 6 Flowers usually reddening........................... strigulosa. 7

1. G. ovata, Nutt. The radical leaves 4 to 6 inches long; calyx-tube scape-lile, 1 to 4 inches long.

2. $\circledast$. graciliflora, Hook \& Arn. Canescently villous; calyx-tube equaling the leaves, 6 to 18 lines long; petals obcordate, 3 to 5 lines long, smaller than the last.

3. $\boxminus$. cheiranthifolia, Horn. Canescently pubescent; stems decumbent or ascending, $2 \mathrm{ft}$. long or more; leaves oblong or narrowly oblanceolate, sometimes broadly ovate or cordate, $\frac{1}{2}$ to $2 \frac{1}{2}$ inches long, mostly entire, the lower petioled, the upper often clasping; ovary and calyx villous; flowers 2 to 5 lines in diameter; capsule 4 to 8 lines long. Niear the sea on drifting sands.

4. Ca. bistorta, Nutt. Less common than the last; distinguished by its petals, 4 to 6 lines long, usually with a brown spot.

5. С. micrantha, IIorn. A variable species distinguished from the last by its flowers, only 2 to 4 lines in diameter, with the petals sometimes 3-lobed; and by the contorted slender capsules, 8 to 18 lines long.

6. CE. dentata, Cav. A span high or less; leaves linear, sessile, denticulate, 6 to IS lines long; petals rounded, 2 to 4 lines long; capsule slender, attenuate, an inch long or more.

7. C. strigulosa, Torr. \& Gr. Like the last; the capsule obtuse, scarcely attenu. ate. More common than the last.

Canothera, biennis, L., the Evening Primrose if found, may be known by its tall, erect stem and large flowers. 


\section{CODETIA, spach.}

Distinguished from Ginothera by the anthers not versatile, and flowers not yellow.

* Flowers in a strict, mostly compact spike; capsule ovate to oblong; stems leafy. Petals deep purple................................... . purpurea. I Petals rose-colored with a spot............................. lepida. 2 Petals bluish-purple, 3 to 5 lines long....................... albescens. 3 * Flowers in usually a loose spike or raceme, mostly nodding in the bud; capsule linear; leaves distant.

- Capsule sessile; stigma-lobes purplish.

Orary and capsule short, villous, 2 -costate................. quadrivulnera. 4 Capsule puberulent, not costate.......................... tenella. 5 + + Capsule pedicellate, not costate, stigma-lobes mostly yellow....... G. amcena. $G$ Small, hispid................................... hispidula, 7 Small, petals 2-lobed..................................... biloba. 8

1. G. purpurea, Wat. Mostly very leafy, a foot or two high, puberulent, the ovary densely villous; leaves oblong to oblong-oblanceolate, an inch or two long, entire, sessile; flowers mostly in a leafy terminal cluster; petals 4 to 6 lines long; style shorter than the stamens; stigma-lobes very short, purple; capsule 6 to 9 lines long, not costate.

2. G. lepida, Lindl. Canescently pulerulent, the stem usually white and shining. Easily distinguished by its flowers; the rose-colored petals with a dark spot near the top 9 to 12 lines long.

3. G. albescens, Lindl. Smaller leaves than the last, and much smaller almost blue flowers. Rare.

4. G. quadrivulnera, Spach. Puberulent, ovary and capsule more or less rillous; stems usually slender, a foot or two high; leaves linear-lanceolate or linear, sessile or attenuate to a short petiole, entire or slightly denticulate, an inch or more long; petals deep-purple or purplish, 3 to 6 lines long; stigma-lobes short, purple.

5. G. tenella, Wat. Chiefly distinguished from the last by the capsule, which is 8 to 14 lines long, with nearly flat sides.

6. G. amcna, Lilja. Petals and purple anthers, frequently rather villous, varying from nearly white to rose-color, with more or less of purple, 8 to 15 lines long; capsule attenuate at each end.

7. G. hispicula, Wat. Is about a span high, often but 1-flowered; leaves narrowly linear; purple petals, 6 to 12 lines long.

8. G. biloba, Wat. Petals 2-lobed. Foot-hills of the Sierra Nevada.

\section{Clarisia, Pursh.}

Petals 4, with claws, entire, purple. Stamens 8. Stigma with 4, at length spreading, 
sometimes unequal lobes. Capsule linear, 4-angled. Annuals, with erect brittle stems and alternate leaves on short petioles.

1. C. elegans, Dougl. Stems from 6 inches to 6 feet high; leaves broadly ovate to linear, repandly toothed; petals rhomboidal; stigma-lobes equal; capsule nearly sessile.

2. C. rhomboidea, Dougl. Is smaller; leaves petioled; claws of the petals toothed; capsule short, pediceled.

\section{EUCHARIDIUM, Fisch. \& Mey.}

Distinguished from Clarkia by the filiform calyx tube prolonged above the ovary, and stameus only 4.

1. Е. concinnum, Fisch. \& Mey. Closely resembles Clarlia rhomboidea in habit and foliage, calyx-tube an inch long; petals 3-lobed. Common.

\section{BOISDUVALIA, Spach.}

Petals 4, obovate-cuniform, sessile, 2-lobed, purple to white. Anthers not versatile. Leaves alternate, simple, sessile; the small flowers in leafy spikes; our species villous.

1. B. densiflora, Wat. Canescent; 6 inches to $2 \mathrm{ft}$. high; leaves lanccolate to linear-lanceolate, mostly denticulate, 1 to 3 inches long; the floral leaves usually short and broad; flowers in usually a close terminal leafy spike or numerous short lateral spikelets; petals 3 to 6 lines long.

2. B. Torreyi, Wat. Rather slender, a span or two high; leaves 4 to 9 lines long; the floral leaves scarcely smaller; flowers very small.

9. Circæa, Pacifica, Asch. \& Magn. In moist woods. Distinguished by its small indehiscent pear-shaped fruit covered with bristles and thin ovate opposite leaves.

\section{Order 25. IOASACEZF.}

Herbaceous plants with either stinging or jointed and rough-barbed hairs; no stipules, calyx tube adnate to the 1-celled ovary. Stamens usually very numerous.

\section{MENTZELIA, L.}

Calyx cylindrical to ovoid; the persistent limb 5-toothed. Petals 5 or 10 . Stamens numerous, inserted below the petals on the throat of the calyx; filaments free or in clusters opposite the petals, filiform or the outer petaloid. Style 3-cleft, the lobes often twisted.-The leaves are alternate, mostly coarsely-toothed or pinnatifid; flowers white to yellow or orange. (See ADDENDA.)

1. M. albicaulis, Dougl. Slender, 6 to 12 inches high or more; leaves linear-lanceolate, pinnatifid with numerous narrow lobes, the upper leaves broader and of ten lobed 
at the base only; flowers near the ends of the branches; petals 5 , spatulate or obovate 2 to 3 lines long; capsule 6 to 9 lines long.

2. M. gracilenta, Torr. \& Gr. Stems similar to the last; petals obovate, abruptly acuminate, an inch long; capsule 12 to 15 lines long.

3. M. lævicaulis, Torr. \& Gr. Stout 2 or $3 \mathrm{ft}$. high; leaves lanceolate 2 to 8 inches long; flowers sessile on short branches, very large, light yellow; petals acute, 2 to $2 \frac{1}{2}$ inches long.

ORDER CUCURBTTACER is represented by Megarrhiza Marah, Wat. (BIGRоoт). The cucumber-like vines, often 10 or even $30 \mathrm{ft}$. long; the sterile flowers white in racemes 4 to 12 inches long; the fruit ovate oblong, more or less covered with weak spines inclosing several nut-like seeds. M. Californica, Torr., has stiffer spines on smaller fruit; the fertile flowers without abortive stamens.

ORDER FICOIDEFE is represented by Mesembryanthemum æquilaterale, Haw., a very fleshy herb, with opposite three sided leaves 1 to 3 inches long and solitary red flowers; the petals numerous, linear. On the sea shore Mollugo verticellata, L., will scarcely be noticed.

\section{ORDER 26. UMBELIIFERF.}

Herbs with small flowers in umbels, stamens and petals 5, borne on a 2-celled ovary which in fruit splits into a pair of dry usually flat indehiscent carpels. Since the generic distinctions depend upon characters of fruit and seed difficult of determination, the plants of this order are not here described.

Order ARALIACEA is represented by Aralia Californica, Wat. (SpIKenard.) Grows in woods, along streams. Herbaceous stems, 8 to $10 \mathrm{ft}$. high; the white flowers in panicles a foot or two long and more.

\section{ORDER 27. CORNACE正.}

Trees or shrubs, rarely herbs, with simple entire mainly opposite leaves, no stipules, and flowers in cymes, capitate clusters or spikes; the petals and stamens 4, epigynous; calyx adnate to the 1-2-celled ovary, which becomes a drupe or berry.

\section{CORNUS, L.}

Flowers perfect. Calyx minutcly 4-toothed. Petals 4, oblong or ovate. Stamens 4, with slender filaments. Style slender; stigma capitate or truncate. Fruit ovoid or oblong.

* Flowers greenish, in a close head, surrounded by an involucre of 4 to 6 large, white, petallike bracts.

1. C. Nuttallii, Audubon. Usually a small tree; the involucre of yellowish or 
white, often reddish bracts, $1 \frac{1}{2}$ to 3 inches long, abmptly acute. Fruit a large cluster of crimson berries.

2. C. Canadensis, L. Stem simple, herbaceous, 3 to 8 inches high; leares in a whorl of 6 at the top, and a pair below; the 4 bracts 4 to 8 lines long.

* Flowers white or cream colored, cymose, not involucrate.

3. C. Californica, C. A. Meyer. A shrub, 6 to $15 \mathrm{ft}$. high, with smooth, purplish branches; leaves ovate acute, obtuse at the base, 2 to 4 inches long, lighter colored beneath, with loose, silky hairs; flowers in small, dense, round-topped cymes.

4. C. glabrata, Benth. Bark gray; leaves oblong to narrowly ovate, acute at each end, alike green on both sides; flowers in open, flat cymes.

GARRYA ELLIP TICA, Dougl. and G. Fremontii, Torr., diœcious shrubs, belong here. The evergreen coriaceous leaves are opposite on the 4-angled branchlets, the short petioles counate; the ap: talot:s flowers in axillary aments. Leaves of the former elliptical, undulate margins; the staminate aments long; leaves of the latter ovate to oblong, not undulate, lighter green.

\section{DIVISION 2. GAMOPETALÆ.}

\section{ORDER 28. CAPRIFOIIACEZI.}

In our species shrubs with opposite leaves, no stipules, the calyx adherent to the 2-5-celled ovary, the stamens as many as the lobes of the rotate or tubular corolla. Corolla rotate, regularly 5 -lobed; white..................... Sambucus. I Corolla bell-shaped, regularly $4-5$-lobed, pinkish............. Symphoricarpus. 2 Corolla tubular, irregular...................................... 3

\section{SAMEUCUS, Tourn. Elder.}

Calyx teeth corolla lobes and stamens 5. Stigmas 3 to 5. Berries really drupes.Shrubs whose rank shoots are filled with a pith, half an inch in diameter. Leaves pinnately 5-11-foliolate. Flowers small, in large compound cymes.

1. S. glauca, Nutt. Cyme flat, 5-parted; fruit black, with a white bloom.

2. S. racemosa, L. Cyme ovate or pear-shaped; fruit bright red. Rare.

\section{SYMPHORICARPUS, Dill. (SNOWBERRY).}

Calyx 5-toothed, occasionally 4-toothed, persistent. Corolla nearly or quite regular, from open campanulate to salver-form, 5-4-lobed. Stamens as many as the lobes of the corolla, inserted on its throat. Fruit globular, white.-Low shrubs, with oval or ob- 
long leaves, mostly entire; and 2-bracteocite flowers in axillary and terminal clusters; rarely solitary.

1. S. racemosus, Mich. Erect, smooth; corolla very villous within.

2. S. mollis, Nutt. Low, diffuse or decumbent, softly pubescent; leaves small; sorolla slightly villous.

\section{LONICERA, I. HONEYSUCKLE.}

Corolla tubular, the tube commonly gibbous at the base and irregularly lobed. Stamens 5 inserted on the tube of the corolla. Style filiform; stigma capitate.

1. I. hispidula, Dougl. Stems disposed to twine; leaves mostly oval, the lower short petioled, the upper pairs commonly connate; foliaceous stipule-like appendages between the leaves common; flowers sessile in a terminal head, pink or yellowish; berries red or orange. Variable.

2. I. involucrata, Banks. An erect shrub, 4 to $10 \mathrm{ft}$. high; leaves ovatc-oblong to broadly lanceolate, short-petioled; flowers a pair on axillary peduncles; below them a conspicuous involucre of 4 bracts, tinged with red or yellow; berries purple-black.

\section{Order 29. RUBIACE正.}

Known by having opposite entire leaves with intervening stipules, or whorled leaves without stipules, along with an inferior ovary and regular 4-5-merous flowers; the teeth of the calyx sometimes wanting. Stamens alternate with the lobes of the corolla and borne on its tube, distinct.

\section{CEPHAIANTHUS, L BUTTON.BUSH.}

Flowers in a dense spherical head. Calyx inversely pyramidal, 4-5-toothed. Corolla with a long, slender tube and a small 4-cleft limb. Stamens 4, borne on the throat of the corolla, short. Style very long and slender.-Shrub with opposite leaves and stipules, or in whorls of 3 or 4 . Peduncles axillary; flowers white.

1. C. occidentalis, L. Leaves ovate or lanceolate, 3 to 5 inches long; flower heads an inch in diameter.

\section{Gajium, I. Cleavers.}

Limb of the calyx obsolete. Corolla rotate, 4-parted, rarely 3-parted. Styles 2. Ovary 2-lobed. Fruit twin, biglobular. Herbs, sometimes woody at the base, with square stems, whorled leaves and minute flowers.

Leaves in fours, hispid, ovate $\ldots \ldots \ldots \ldots \ldots \ldots \ldots \ldots \ldots \ldots$. Californicum. I Leaves in fours and pairs, smooth....................... Nuttallii. 2 Leaves mostly in whorls of eight......................... Aparine, 3 
Leaves in fives and sixes; fruit hairy...................... triforum. 4 Leaves 4,5 or 6 in a whorl; flowers white................... trifidum. 5 Leaves in fours, 3 -nerved, lanceolate....................... boreale. 9

1. G. Californicum, Hook and Arn. Low, branching; sterile flowers terminal, in threes, corolla yellowish; fertile ones solitary, recurved in fruit; fruit purple.

2. G. Nuttallii, Gr. Leaves 2 to 5 lines long, thickish, varying from ovate-oblong to linear-lanceolate, margins ciliate; flowers solitary.

3. G. Aparine, L. The margins midrib, and angles of the branches armed with spinulose bristles; peduncles 1-2-flowered; fruit large, white.(?)

4. G. triflorum, Michx. Bright green, nearly smooth; leaves oblong-lanceolate, acute at both ends, the margins and midrib often beset with hooked bristles; peduncles once or twice 3-forked; with hooked bristles.

5. G. trifidum, L. Nearly smooth, except the roughened angles of the slender stems; leaves 3 to 9 lines long; lobes of the white corolla often only three; fruit smooth.

6. G. boreale, L. Cymes many flowered, in a thyrsiform panicle.

\section{ORDER 30. VALERIANACER.}

Herbs with opposite leaves, no stipules; the distinct stamens fewer than the lobes of the corolla, and borne on its tube; the inferior ovary with two empty cells, and one containing a solitary ovule, ripening into a kind of akene.

\section{PLECTRITIS, (Lindl.) DC.}

Limb of the calyx obsolete. Tube of the corolla very gibbous, spurred at the base; the short limb bilabiate; upper lip 2-cleft, lower 3-cleft. Fruit winged by the ojen sterile cells. Flowers white, small.

1. P. congesta, DC. Corolla about 3 lines long; its spur much shorter than the tube.

2. P. macrocera, Torr. \& Gr. Corolla smaller; its thick spur about the length of the bodj.

\section{ORDER 31. COIMPOSIT工凡.}

Flowers, usually many in a dense head, sessile, on a common receptacle, surrounded by a calyx-like involucre; the calyx reduced to hairs or scales, or obsolete; the corolla tubular, equally lubed, ligulate or bilabiate, the 5 stamens united by their anthers into a tube inclosing the 2-parted style; the ovary inferior forming in fruit an akene which is usually crowned with the persistent calyx (pappus).

This the largest of all the orders, is represented in California by over 500 species, 140 
of which grow within the limits of this Flora. Although the flower heads are frequently large, the separate flowers, with but few exceptions, are too small to be examined without the aid of a microscope skillfully used. The order is, therefore, far too difficult for the beginner.

ORDER LOBELIACEA. Downingia elegans, Torr., and D. pulchella, Torr., are two beautiful plants (the flowers resembling the cultivated Lobelias) sometimes cultivated under the name Clintonia, which properly belongs to an endogenous herb. The former has light blue flowers; the latter, deep azurebluc; both with white or yellowish centers. May be found in wet places.

\section{Order 32. CAMPANULACE}

Herbs with alternate leaves without stipules and regular flowers, having the calyx adnate to the ovary, distinct stamens (5, rarely 4) inserted with the corolla, alternate with its lobes.-Calyx persistent. Stamens with introse anthers, opening in the bud. Style single, its upper portion beset with hairs which collect the pollen, its summit 2-5lobed or cleft.

* Ovary and capsule long and narrow.

Capsule opening at the top; calyx-lobes long................................. I Capsule opening by 2 or 3 holes on the sides.................... Specularia. 2

* * Ovary and capsule short and broad, or globular.

Capsule bursting indefinitely; calyx-lobes broad.................Heterocodon. 3 Capsule opening on the sides by 3 to 5 holes; calyx-lobes narrow....... Campanula. 4

\section{GITHOPSIS, Nutt.}

Flowers all alike. Calyx with a clavate 10-ribbed tube, and 5 long and narrow foliaceous lobes. Corolla tubular-campanulate, 5-lobed. Filaments short, dilated at the hase. Ovary 3-celled; stigmas 3. Capsule strongly ribbed, crowned with the rigid calyx-lobes of its own length or longer, opening between them by a round hole.

1. G. specularioides, Nutt. An inch to a span high; leaves lanceolate-oblong or linear, sessile, coarsely toothed; flowers erect, deep blue, usually with a white center; the ovate lobes of the corolla about equaling the rigid calyx-lobes.

\section{SPECULARIA. Heister.}

Flowers in our species of two kinds; the lower and earlier usually with no corolla, Calyx-tube prismatic or elongated-obconical; the lobes 5, narrow: Corolla short and broad, rotate when fully expanded, 5-lobed. Stigmas 3 or 2. Capsule opening by round holes on the sides.

1. S. biflora, Gr. Stems slender; leaves sessile, ovate or oblong, crenately toothed, the upper reduced to lanceolate bracts; flowers 1, rarely 2, in each axil, nearly sessile; the 
lower mostly apetalous, with 3 or 4 short calyx-lobes; the upper with 5 longer calyxlobes, which are shorter than the blue or purple corolla. Capsule with openings near the top.

2. S. perfoliata, A. DC. Stouter, with clasping cordate leaves.

\section{IIETEROCODON, Nutt.}

Flowers of two sorts. Stamens and styles as in Campanula. Capsule 3-angled. Otherwise sufieiently characterized in the synopsis.

1. I. rariflorum, Nutt. A delicate annual, with leafy filiform stems, diffusely branching; the thin leaves clasping by cordate bases, coarsely toothed. Corolla blue.

\section{4. campanula. Tourn. Bellflowtr.}

Flowers all alike. Calyx-lobes narrow. Corolla campanulate or near it, 5-lobed. Stamens 5; filaments dilated at the base. Capsule 3-5-celled, opening on the siles or near the base by 3 to 5 small uplifting valves leaving round holes.

1. C. prenanthoides, Dur. A foot or two high; stems several-flowered; leaves ovate-oblong or lanceolate, sharply serrate, sessile, or the lower short-petioled; lobes of the blue corolla narrowly lanceolate, widely spreading; style long exserted; capsule 5-ribbed.

\section{ORDER 33. ERICACEF.}

Woody plants or perennial herbs, with symmetrical and mostly regular flowers; the stamens as many or twice as many as the petals or lobes of the corolla, and inserted with but rarely upon it; the anthers 2-celled, and the cells opening by a terminal pore; the ovary with as many cells as the divisions of the corolla or calyx; the seeds small. Corolla generally gamopetalous, sometimes of distinct petals, the insertion and that of the stamens hypogynous, or when the calyx is adnate epigynous around an annular disk. Stylo single. Leaves simple.

\section{SUB-order 1. VACCINIJZg.}

Shrubs. Ovary wholly or partly inferior. Fruit a berry, crowned with the vestiges of the calyx-teeth $\ldots \ldots \ldots \ldots \ldots \ldots \ldots \ldots \ldots \ldots \ldots$ Vaccinium 1

\section{SUb-order 2. ERICINEZ.}

Shrubs or trees. Calyx free. Corolla gamopetalous (in our own species). Stamens hypogynous. Anthers introse in the bud. 
- Fruit a terry, or berry-like drupe; corolla-tube inflated or urn-shaped, 5-toothed. Evergreen.

Tree; ovary 5 -celled; berry many-seeded.................................. 2

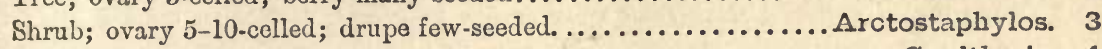

Shrub; low; berry purple-black .......................... Gaultheria. \&

* Fruit a nalied capsule; corolla funnelform or campanulate, large, 5-lobed.

Shrubs, with showy flowers

.Rhododendron. 5

\section{SUB-ORDER 3. PYROLEF.}

Calyx free. Corolla of 5 (rarely 4 ) separate petals. Anthers extrose in the bud, the pores downward; introse (by bending downward on the end of the filament) in the open flower, the pores upward.

Stem woody, leaves whorled..................................maphila. 6

Flowers on a scape......................................Pyrola. 7

\section{SUB-ORDER 4. MONOTROPEZS.}

Root-parasitic, scaly-bracted herbs, wholly destitute of green foliage.

Flowers racemose, corolla globular-ovate ........................... 8

\section{VACCINTUM, L. Blueberry, Bilberry, Etc.}

Calyx 4-5-toothed on the summit of the ovary. Corolla various. Stamens 8 to 10; the anthers with the two cells separate, tapering upward into a tube opening at the top. Style long.

1. V. ovatum, Pursh. (California Huckleberry). Shrub, erect, 3 to $5 \mathrm{ft} \mathrm{high \text {; }}$ evergreen; leares thick, shining, ovate, acute, serrate; flowers with the parts in fives, stamens 10; corolla campanulate, pink; berries purple-black.

\section{ARBUTUS, Tourn. Madrono.}

Calyx 5-lobed. Corolla ovate, 5-toothed; the teeth recurved. Stamens 10, included; anthers flattened, furnished with a pair of reflexed awns. Style rather long; berry with a rough surface.

1. A. Menziesii, Pursh. A handsome tree, with smooth bark turning brownishred, which exfoliates except on the trunks of the larger trees; corolla white; berries deep orange.

\section{ARCTOSTAPHYLOS. Adan. Manzanta.}

Flowers like those of Arbutus (but occasionally 4-merous and 8-androus), except that the 5 to 10 cells of the ovary contain each a single ovule, and the berry-like fruit has 5 
to 10 bony seeds. - The white or rose-colored flowers in terminal racemes; the bark smooth, exfoliating.

* Ovary and depressed-globose fruit more, or less pubescent; branchlets often hispid.

1. A. Andersonii, Gr. Erect, 6 or $10 \mathrm{ft}$. high; branchlets minutely tomentose, hispid with long, white, bristly hairs; leaves thin-coriaceous, green, lanceolate-oblong or ovate lanceolate, with a strongly sagittate-cordate base, sessile or nearly so, mostly spinulose-serrulate; fruit nearly or quite half an inch in diameter, with viscid bristles.

2. A. tomentosa, Dougl. Leaves thick and very rigid-coriaceous, varying from oblonglanceolate to ovate and even cordate, entire or rarely serrulate, usually becoming verti. cal, smaller than the last; flowers in very short clustered racemes; fruit not viscid.

\section{* *vary glabrous; no hispid hairs on the branches and petioles.}

3. A. pumila, Nutt. Erect, dwarf, less than a foot high, tufted; leaves broadest near the apex, less than an inch long.

4. A. pungens, HBK. Leaves commonly becoming vertical by a twist of the distinct or pretty long petiole, very rigid, often glaucous or pale, entire or with a few teeth, varying from oblong-lanceolate to oval; flowers on smooth pedicels; filaments ciliate, bearded; fruit yellowish, turning dull red. Very variable.

A. GLACC.I, Lindl., if found, myy be recognized by its large fruit, with the seeds consolidated Into one woody stone, half an iuch in diameter. A. bicolor, Gr., is smaller aud has small appareitly one-seeded berries.

\section{GaULthiria, L. Wintergreev. Salat.}

Calyx 5-cleft, generally colored like the corolla. Corolla 5-toothed. Stamens 10 included, similar to those of Arbutus. Capsule 5-lobed, 5-celled, many-seeded, inclosed in the calyx, which enlarges and makes a juicy berry-like fruit.

1. G. Shalion, Pursh. Shrubby, stems ascending a foot or two in height; leaves ovate or slightly cordate, 2 to 4 inches long, finely serrate, shining; flowers white or rosecolored, in glandular-viscid racemes.

\section{RHODODENDRON, L.}

Calyx very small. Corolla often slightly irregular. Stamens 5 to 10 ; filaments filiform. Style long, commonly declined or ineurved. Shrubs with alternate, entire leaves, usually crowded on the flowering branchlets; the showy flowers in terminal umbels or corymbs from ample scaly buds.

1. R. oxcidentale, Gr. (Azalea.) A deciduous shrub, 2 to $6 \mathrm{ft}$. high; leaves obovate-oblong, bright green and shining above; corolla minutely viscid-pubescent outside, white, the upper lobe yellowish inside; the narrow funnel-form tube equaling the deeply 5-cleft slightly irregular limb; stamens and style much exserted, curved.-The showy fragrant flowers are sometimes nearly three inches long; rarely pinkish.

R. CALIFORNICUM, Hook., is a larger evergreen shrub, with large bell-shaped rose-purple flowers * a true Rlododendron, probably not found south of IIEndocino County. 


\section{Chimaphita, Pursh. Pipsissewa.}

Corolla of rotately spreading, orbicular and concave petals. Stamens 10. Style very short, inversely conical, nearly immersed in the depressed ovary; stigma broad, its border somewhat 5-crenate.

C. umbellata, Nutt. A nearly herbaceous evergreen, 6 to 18 inches high; the usually whorled leaves oblanceolate, bright green; peduncle bearing 3 to 7 white or flesh-colored, waxy flowers.-Mt. St. Helena, Miss E. Swett.

\section{PYROLA, Tourn.}

Corolla of 5 concave and converging petals. Stamens as in Chimaphila. Style generally long; stigma 5-lobed or 5-rayed.-Low and smooth perennial herbs, with broad and petioled leaves, close to the ground, and more or less scaly-bracted scape bearing a simple raceme of white, greenish or rose-colored, nodding flowers.

1. P rotundifolia, L. Leaves orbicular, varying to round-obovate or round-reniform, on slender, naked petioles; scape 6 to 14 inches high; probably our plants are of the Var. bracteata, Gr. A large form, with leaves 2 or 3 inches long; scape often over a foot high.

2. P. picta, Smith. Leaves thick, coriaceous; pale, sometimes purplish below; commonly blotched with white, ovate to obovate and lanceolate-oblong, on short petioles, 1 to 2 inches long; smaller than the last.

\section{PTEROSPORA, Nutt.}

Calyx deeply 5-parted, short, persistent. Corolla withering-persistent, globular-ovate, with contracted mouth; the 5 very short lobes, recurved. Stamens 10, included, short; stigma 5-lobed.

1. P. andromedea, Nutt. A stout, purplish-brown or chestnut-colored and clammy-pubescent herb, 1 to $3 \mathrm{ft}$. high; raceme long, many-flowered; corolla white, 3 lines long.

Sarcodes sajguinea, Torr. The Snow Plaxt of the Slerra Nevada belongs here.

\section{ORDER 34. PLUIMBAGINACEFE.}

Chiefly maritime herbs, with regular flowers, the parts in fives; the stamens opposite the petals. Calyx tubular or funnel-form, 5-plaited, 5-toothed, persistent. Corolla in our genera with the long-clawed petals scarcely united. Stamens adnate to the base of the petals.

Flowers in a globose head on a simple scape..................... Armeria. I Flowers on a branching scape....................................... 2 


\section{ARMERIA, Willd. THRIFT.}

Calyx scarious, funnel-form. Styles 5, filiform. Stemless perennials, with linear grass-like leaves in close tufts, the naked scape bearing a liead of rose-colored flowers.

1. A. vulgaris, Willd. Scapes a foot or two high. On sandy hills along the coast.

\section{STATiCE, L. Marsh-Rosemary.}

Flowers in small spikes or clusters, crowded at the extremities of a branching scape; their structure nearly as in Armeria. Leaves commonly with a broad blade, tapering into a petiole.

1. S. Limonium, L. Leaves obovate-oblong; spikelets 2-3-flowered. Salt marshes.

\section{Order 35. PRIMULACEZg.}

IIerbs, with perfect, regular flowers, well marked, by having the stamens as long as the lobes of the corolla, ancl opposite to them, inscrted on its tube, a single entire stylo and stigma, a one-celled ovary, and capsular fruit. Calyx 4-8-cleft, commonly 5-cleft, lyyporynous. -Leaves simple; stipules none. In Glaux the corolla is wanting; stamens on the calyx alternate with its lobes.

* Flowers umbellate on a nalied scape.

Corolla deeply 4-5-parted, the lobes reflexed.................. Dodecatheon. I

* * Flowers axillary, on leafy stems.

Corolla $5-9$-parted, rotate................................. Trientalis. 2

Corolla 5 -parted; prostrate stems..........................nagallis. 3

Corolla wanting; calyx colored................................... \&

\section{DODECATEEOI, L.}

Calyx deeply 5-cleft, the divisions reflexed in the flower, afterwards crect over the ovate or oblong capsule. Corolla with a very short tube, a clilated, thickened throat and an abruptly reflexed 4-5-parted limb; its divisions long and narrow, entire. Stamens inserted in the throat of the corolla, erect, cohering around the slender exserted style. Acaulescent perennial smooth herbs, with a tuft of radical leaves. Corolla purple, pink, or rarely white. Frequently the parts are in fours.

1. D. Meacia, L. Leaves varying from obovate to lanceolate, entire or toothed; scape 3 to 15 inches high; umbel, 2-20-flowered. A variable species. Ours is chiefly the

Var. brevifolium, with leaves round-obovate or spatulate, less than an inch to an incls and a half long. 


\section{ASCLEPIADACEA. (MIKIWEED FANTH.)}

\section{TrIENTAIIS, L. Star-flower.}

Calyx and wheel-shaped corolla about 7-parted. Filaments slender, spreading.-Low and glabrous perennials, with simple stems, which bear a whorl of leaves at the summit, in their axils slender peduncles supporting star-shaped, white or pinkish flowers.

1. T. Europæa, L., Var. latifolia, Torr. Stems 4 to 8 inches high, springing from a little tuber.

\section{ANAGalits, Tourn. Prmpernel.}

Divisions of the rotate 5-parted corolla broad. Capsule globose.-Spreading, prostrate herbs, with opposite or whorled leaves and axillary flowers.

1. A. arvensis, L. Leaves ovate, sessile, shorter than the peduncles, sometimes in threes; flowers scarlet, purple. or nearly salmon-colored, rarely blue.

Haveh

\section{GiauX, L. Sea Milikwort.}

Calyx campanulate, 5-cleft; the lobes ovate, petal-like. Filaments rather shorter than the calyx. Style filiform; stigma capitate.

1. G. maritima, L. Low, glabrous; branching stems 3 to 9 inches high, leafy to the top; leaves commonly opposite, fleshy, oblong, half an inch or less long, minutely dotted; flowers axillary, almost sessile, white or purplish.

ORDER OLFACEA is represented by Fraxinus Oregana, Nutt., the Oregor AsH. ORDER APOCYNACEI is represented by Apocynum cannabinum, L. (INDIAN HEMP.) An herb with milky juice, tough bark, opposite entire exstipulate leaves, regular fiowers, the sepals, petals and stamens five, the latter borne on the corolla alternate with its lobes and conniving around the stigma. The commonly sessile, oblong leaves often 3 or 4 inches long. The greenish-white small flowers in close cymes. A. androsamifolium, L., has smaller ovate leaves, conspicuously petioled; flowers rose-colored.

\section{Order 36. ASCIFPIADACE西.}

Herbs with milky juice, no stipules, and regular flowers, with the parts in fives, excent that there are two carpels with distinct ovaries and a common stigma to which the stamens are attached; the latter (in our genera) with hood-like appendages. Leaves entire, generally opposite, sometimes whorled. Flowers usually in simple umbels. Fruit a pair of follicles. Seeds almost always with a coma of silky down.

\section{ASCLEPIAS, L. MILKWEED.}

The calyx and corolla deeply 5-parted; the small divisions reflexed; filaments short, crowned behind each anther with a conspicuous hood from the cavity of which rises the subulate and usually falcate hcrn; anthers with thin scarious tips inflexed 
over the truncate summit of the stigma, their wing-like edges meeting and projecting between the hoods; pollen in 10 wax-like inasses. Follicles ovate or lanceolate. Seeds sumerous, flat, downwardly imbricated all over the large, soon detached placenta; the upper end with a long tuft of down (coma).- Hoods in our species erect and not exceed. ing the stamens and stigma.

1. A. fascicularis, Decaisne. Smooth, slender, 1 to $5 \mathrm{ft}$. high; leaves in whorls of 3 to 5 , or some in pairs, linear and linear-lanceolate; flowers white or whitish; horns longer than the hoods.

2. A. vestita, Hook \& Arn. White-woolly; leaves opposite, ovate-lanceolate or oblong-lanceolate, almost sessile; umbels almost sessile; flowers about half an inch long, the hoods flesh-colored.

\section{GOMPHOCARPUS, R. Br.}

No horn to the hood of the stamens; otherwise as Asclepias.

§1. Hoods saccate, pointless, lower than the anthers, opening down the back, as if 2 -valved.

1. G. tomentosus, Gr. White-tomentose, elosely resembling Asclepias vistitia; stem acutely angled; leaves orate or oblong (about 4 inches long); corolla greenish-white or purplish.

2. G. purpurascens, Gr. Canescently puberulent; stems 4 to 12 inches high; leaves ovate and somewhat cordate, an inch or two long; flowers small; the corolla redpurple; the hoods white.

§ 2. Hoods erect, open down the front, somewhat surpassing the anthers.

3. G. cordifolius, Benth. Green and smooth, 2 or $3 \mathrm{ft}$. high; leaves ovate or ovatelanceolate, with cordate clasping base, opposite, rarely in threes, 2 to 5 inches long; flowers large; corolla dark red-purple; the hoods purplish.

\section{Order 37. GENTIANACEZ玨。}

Glabrous herbs, with colorless, bitter juice, entire opposite and sessile leares, no stipules, perfect and regular flowers, stamens as many as the lobes of the corolla and alternate with them, inserted on the tube, the anthers free from the stigma; ovary 1-celled; style one or none; the stigmas commonly two. Calyx persistent.

§ 1. Corolla withering-persistent. Leaves opposite or whorled, entire, sessile. Corolla salver-form, red; calyx 5 -parted...................... Erythræa. I Corolla short, salver-form, yellow; eaylx 4-toothed...............Microcala. 2 Corolla funnel-form, blue.......................................... 3

§ 2. Corolla deciduous. Leaves alternate, with sheathing petioles. Flowers borne on a naked scape.........................Menyantines, 
1. ERYTERESA, Pers.

Stamens inserted on the throat of the corolla; filaments slender; anthers oblong or linear, twisting spirally after shedding the pollen. Style filiform; stigma wedge-shaped or fan-like. Capsule oblong, tapering upward.-Corolla occasionally only 4-parted.

1. E. trichantha, Grise. A span or less high, branched; lobes of the rose-red corolla lanceolate, fully half the length of the tube at the time of expansion, 3 or 4 lines long; calyx-lobes filiform, 3 -angled.

2. E. Muhlenbergii, Grise. Two inches to a span high, simple or branched; leaves oblong, half an inch loug; lobes of the corolla oval, very obtuse, becoming oblung, rose-red.

\section{MICROCAIA, Link.}

Anthers round-cordate. Stigma peltate-dilated, at length separating or separable into 2 plates.

1. M. quadrangularis, Grise. An inch or two high, filiform, simple and l॰flowered, or branched at the base, with 1 to 3 pairs of minute oval or oblong leaves; peduncles naked, square; calyx short, square; corolla saffron-yellow.

\section{3. geivtiana, L. Gentian.}

Calyx 4-5-toothed or cleft. Corolla 4-5-lobed, often with plaited and toothed folds in the sinuses. Stamens included; anthers sometimes cohering. Style none or very short; stigmas 2, thin and flat.

1. G. affunis, Grise., var. ovata, Gr. A span to a foot or two high; leaves ovate or oblong; flowers mostly 5 or more, in a leafy thyrsus; corolla blue, an inch or more in length; appendages mostly 2-cleft or 2-4-cuspidate, shorter than the round-ovate lobes.

\section{MENYANThES, Toum. Buckbean.}

The campanulate corolla densely white-bearded on the upper surface, the lobes with the margins turned inward in the bud.

1. IM. trifoliata, L. The alternate leaves long petioled, 3-foliolate; scape tcrminated by a short raceme of white or pinkish flowers; anthers dark-brown, sagittate. - In sliallow water or on wet ground.

\section{ORDER 38. POLEMONIACEZF.}

Chiefly herbs with simple or divided leaves, and no stipules; all the parts of the regular flower five, except the pistil, which has a 3-celled ovary and a 3-lobed style. Calyx imbricated in the bud, persistent. Corolla convolute in the bud. Stamens on the corolla alternate with its lobes distinct; anthers introse. - In Gilia the cells of the ovary and the stigmas are occasionally reduced to two. 


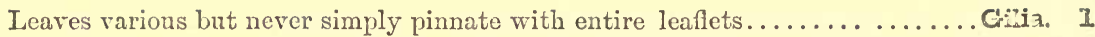
Leaves simply pinnate; leaflets linear to ovate; corolla short........Polemouium. 2

\section{GIIIA. Ruiz \& Pav.}

Corolla funncl-form, salver-form, or sometimes short-campanulate or rotate, regular. A polymorphous gemus, the seetions having almost generic differences.

Series I. Stamens attached to the corolla at unequal heights.

Mostly viscid-pubescent or glandular; all but some of the lower leaves alternate; stamens exserteul.

$\S$ Collomia.

Srrirs II. Stamens equally inserted, but sometimes with unequal filaments.

* All of the leavcs opposite, at least on the main stems, sessile and palmately parted or rarely entire. (Seeds mucilaginous in vater.)

Corclla from short funnel-form to almost rotate; the lobes obovate; filaments slender; anthers oval. Low or slender, loosely and mostly small flowered annuals; the leaves with filiform or setaceous divisions, appearing as if whorled. In ours, the flowers on filiform pedicels, loosely paniculate.

§. Dactylophyllum.

Corolla salver-form, but the tube shorter than the calyx, the broad cuneate-obovate lobes slightly crenulate, strongly convolute in the bud; stamens inserted low on the corolla tube, included; erect, smooth; leaves entire or 3-5-divided.

§. Linanthus.

Corolla salver-form, with usually a filiform elongated tube, and the throat sometimes abruptly dilated; stamens inserted in the throat; anthers short. Erect annuals, with leaves as in the last, and the flowers in a terminal capitate cluster.

§ 3. Leptosiphon.

\section{* All the leaves alternate and palmately parted.}

Corolla similar to $\S 3$. Stems woody; leaves much fascicled in the axils, 3-7 parted, rigid; flowers sessile, solitary or few at the ends of short branches. §4. Leptodactylon.

* * All, or all but the lowest leaves alternate and pinnately compound, cleft or toothed, or rarely entire.

Flowers capitate-glomerate or densely clustered, leafy-bracted; bracts and calyx-lobes often laciniate, rigid acerose or spinulose-tipped. Corolla slender tubular-funnelform, with small oblong lobes; cells of the ovary and stigmas sometimes only 2. Annuals, mostly viscid-pubescent, never white-woolly, with once or twiee pinnatificl leaves, their lobes commonly pungent; the bracts sometimes palmately cleft.

§5. Navarreita.

Flowers, inflorescence, etc., nearly as in $\S 5$; but the anthers always exserted; corolla salver-form, more conspicuous; plants all white-woolly, not viscid.

§ 6. Hugelia.

Flowers capitate-glomerate, or panicled, or scattered, usually bractless; corolla (blue, 
purple or violet) from funnel-form to campanulate or almost rotate; stamens included or not surpassing the corolla lobes; leaves most pinnately incised.

§7. Euqilia.

$\S$ Collomia. [See p. 138.]

* Leaves simple, sessile, entire, lower ones often opposite.

1a. G. grandiflora, Gr. Erect, a foot or two high; leaves linear to lance-ovate; calyx-lobes broad and obtuse; corolla buff or salmon-color, narrow-funnel-form, an inch long. The showy flowers are in leafy-bracted heads.-Sonoma County, Lake County, E. Brooks. Collomia grandiflora, Dougl. of 4 th Ed.

1b. G. gracilis, Gray. A span or two high, in age much branched; the flowers at length somewhat scattered; leaves lanceolate or linear, or the lowest oval or obolate, an inch or less long; corolla rose-purple, turning bluish, less than half an inch long, narrow. Collomia gracilis, Dougl. of previous editions.

* * Leaves, deeply cleft or compound, the lower petioled; stems loosely branched.

1c. G. divaricata, Nutt. A span to $3 \mathrm{ft}$. high; lower leaves simply pinnately parted into linear lateral lobes, or the terminal lobe oblong and toothed, upper leaves 3-5divided; corolla pink or purplish, its slender tube about half an inch long, twice or thrice the length of the calyx; capsule globular, 3-seeded. Collomia gilioides, Benth.

1d. G. Sessei, Don. A span or two high, diffuse; leaves mostly pinnately parted or the upper pinnatifid, and the lobes incised or cleft; the upper most often entire and broader, subtending the capitate-clustered flowers; corolla purplish, half an inch long; stamens very unequally inserted. Collomia heterophylla, Hook.

\section{§1. Dactylophyllum. Benth.}

1. G. liniflora, Benth. From a few inches to over a foot high; leaves with nearly filiform divisions an inch long; corolla white, rotate, when fully open, 10 to 6 lines across, 5-parted down to the very short tube.

Var. pharnaceoides, Gr., is similar but smaller; the (sometimes pinkish) corolla half an inch across, or less.

2. G. pusilla Benth. Small, 2 to 6 inches high; leaves less than half an inch long, shorter than the scattered pedicels; corolla nearly white, or purplish with a yellow throat, $1 \frac{1}{2}$ to 2 lines long, little exceeding the calyx.

Var. Californica, Gr., has a corolla 3 lines long, twice the length of the calyx; the throat often brownish. The most frequent form.

3. G. Bolanderi, Gr. Very like the last, but the tube of the blue or purple tinged corolla longer and narrower (3 or 4 lines long).

4. G. aurea, Nutt. Diffuse, 2 to 4 inches high; divisions of roughish leaves narrowly linear, 3 lines long; peduncles shorter or but little longer than the flowers; corolla usually yellow, short, funnel-form half an inch or less across; the roundish-obovate lobes abont the length of the obconical throat and the short proper tube. 
Var. decora, Gr. Corolla white or pale violet, with or without a brown-purple throat; peduncles longer.

\section{§ 2. Linanthus, Endl.}

5. G. dichotoma, Benth. A span to a foot high, remotely leaved; flowers nearly sessile in the forks, or terminating the branches; calyx-tube white scarious; the teeth green; corolla white; the lobes from half to nearly an inch long; the tube sometimes purplish.

\section{§ 3. Leptosiphon, Endl.}

6. G. densiflora, Benth. A span to $2 \mathrm{ft}$. high; leaves in somewhat distant apparent whorls; tube of the white or rose-purple corolla about equaling the villous-hirsute bracts and calyx; its lobes nearly half an inch long, obovate.

7. G. androsacea, Steud. Erect or spreading, 3 to 12 inches high; corolla lilac, rose, pink or almost white, with a yellow or dark throat; its tube about an inch long.

Var. rosacea, Gr., is a dwarf tufted form with many rose-red flowers.

8. G. micrantha, Steud. Slender, about a span high; tube of the corolla very slender, 9 to 18 lines long; the lobes 2 or 3 lines long, from yellow to cream color and pale purple, or whitish.

9. G. tenella, Benth. Low and mostly depressed; tube of the corolla 6 to 9 lines long, the rose colored or pink lobes barely a line and a half long, the throat yellow; bracts and leaves hispidulous-ciliate.

10. G. ciliata, Benth. More rigid and hirsute than the preceding, a span to a foot high; tube of the rose-colored or purple, or in age whitish corolla, little if at all exserted beyond the very hirsute or hispid-ciliate bracts and subtending leaves, the lobes only a line and a half long.

\section{§4. Leptodactylon, Hook \& Arn.}

11. G. Californica, Benth. Two or three feet high, with spreading rigid branches; corolla rose-color or lilac, an inch and a half in diameter.

\section{§5. Navarretia, Gr.}

- Stamens included in the throat of the corolla.

12. G. quarrosa, Hook \& Arn. Rigid, rather stout, becoming much branched, very glandular-viscid, fetid with the odor of a skunk; upper leaves and bracts spinescent; corolla blue, 4 or 5 lines long.

* * Stamens more or less exserted; corolla slender, 3 to 5 lines long. Leaves twice pinnatifid.

13. G. cotulæfolia Steud. Rather stout and rigid, a foot or much less in height; villous pubescent and ininutely glandular; upper bracts spinescent; tube of the violet or whitish corolla hardly longer than the calyx; capsule usually 1-seeded. Exhales the odor of Anthemis cotula (MAYwEed).

14. G. intertexta, Steud. At length difiusely much branched, a span high, neither 
viscid nor glandular; stems retrorsely pubescent; leaves mainly smooth, scarcely bipinnatifid; base of the bracts and tube of the calyx densely white-villous; corolla white.

15. G. leucocephala, Gr. A span high, rather slender, loosely branched, smooth, except a little woolliness at the top; leaves soft; bracts hardly pungent; heads dense; corolla white, longer than the calyx.

* * Stamens exserted; leaves only once pinnatifid, rigicl, linear; corolla violet or purple, barely half an inch long, about twice the length of the pungent calyx-lobes.

16. G. viscidula, Gr. A span high or less, at length much branched, viscid-pubescent; bracts palmately cleft.

17. G. atractyloides, Steud. Much more rigid than the last; leaves broader, the floral ovate, all with subulate spiny lobes; few flowered.

\section{§6. Hugelia, Benth.}

* Root perennial; stems woody at the base.

18. G, densifolia, Benth. A foot or two high; stems leafy, leaves linear, rigid, the short lobes subulate; flowers numerous in a compact head; corolla over half an inch long, violet blue, exceeding the calyx, the lobes 3 lines long; anthers sagittate.

* Root annual, stems slender, a foot or less in height; leaves and their few (if any) divisions filiform.

19. G. virgata, Steud. Tube of the blue corolla longer than the calyx; anthers sagittate.

Var. floribunda, Gr. Low and rather stout; even tbe upper leaves pinnately 3-7-parted; the numerous heads and flowers as large as $G$. densifolia.

\section{\$7. Eugilia, Benth.}

* Flowers numerous in dense head-like clusters on long naked peduncles; stems erect; stamens inserted in the very sinuses of the short and broad corolla; leaves twice or thrice pinnately dissected into linear divisions.

20. G. capitata, Dougl. Mostly smooth; stem slender, loosely branched above, a foot or two high; lobes of the light blue (rarely white) corolla narrowly oblong, 2 lines long.

21. G. achilleæfolia, Benth. Stouter and lower than the last, often glandular; the capitate clusters and flowers larger; calyx woolly; lobes of the deeper blue corolla broad.

* Flowers in small, rather loose clusters, or scattered in an open panicle.

22. G. multicaulis, Benth. A span to a foot high, simple in early plants, loosely branched in later; flowers few in a cluster terminating the slender naked pecluncles, almost sessile; the violet corolla 4 lines long, tube shorter than the viscid calyx; throat funnel-form; capsule ovoid. 
Var. tenera, Gr., is a depauperate form; frequently the peduncles only 1-flowered.

23. G. tricolor, Benth. A span to a foot or two high, in age diffusely branched; flowers few, in loose, rather short peduncled clusters; corolla with a very short proper tube and an ample campanulate throat which is pale yellow or orange below, dark purple above; the lilac or violet lobes longer than the stamens.

24. G. inconspicua, Dougl. A span to a foot high, somewhat viscid or glandular; corolla violet-purple or bluish, twice or thrice the length of the calyx, but small, the lobes only a line long. It passes by gradation into

Var. sinuata, Gr., with the tube of the corolla more slender and exserted and the lobes often 2 lines long.

\section{POLEMONIUM. Tourn.}

Flowers as in Gilia, § Eugilia, but the corolla short and broad, the stamens somewhat declined, the filaments hairy appendaged at the base. Calyx herbaceous, its divisions and those of the pinnate leaves pointless.

1. P. cæruleum, L. (Greek Valerian.) Smooth or viscid-pubescent, 2 or $3 \mathrm{ft}$. high, leafy, usually bearing numerous flowers; corolla an inch or more across, bright blue varying to white; stamens and style exserted. [See bottom of p. 122.]

\section{ORDER 39. HYDROPHYLIACEZE.}

Inflorescence usually scorpioid; flowers perfect, regular, 5-androus, the two styles distinct at least at the apex; stigmas terminal, small, capitate. Only in Romanzoffa are the stigmas as well as the styles united. Ovary commonly hispid or hirsute, at least at the top.-Mostly herbs, with alternate or rarely opposite leaves and no stipules.

Tribe 1. FYDROPHYILEZE. Ovary and capsule 1-celled. Style 2-cleft. Corolla almost always convolute in the bud. Herbs.

Flowers solitary or loosely racemose.

Calyx with reflexed appendages. Nemophila. 1 Calyx naked at the sinuses................................... 2

Tribe 2. PHACELIEßE. Ovary 1-2-celled. Style 1-2-cleft. Corolla imbricated in the bud. Calyx naked at the sinuses. Herbs.

Corolla not yellow, deciduous...................................... 3

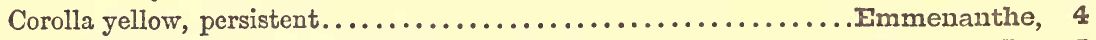

Style and stigma entire.................................... 5

Tribe 3. NAMERs. Ovary, capsule, dehiscence, etc., nearly of Phacelica. Styles distinct to the base, stigmas capitate.

Low shrubs. 


\section{NEMOPHILA, Nutt.}

Calyx 5-parted. Corolla rotate-campanulate, deeply 5-lobed, the throat appendaged with 10 internal plates or scales.-Tender herbs with diffuse and procumbent stems, and pinnately lobed or divided leaves, more or less hirsute.

* Leaves mostly alternate; stems long and weak, beset with stiff reflexed bristles.

1. IN. aurita, Lindl. Leaves large, with auriculate dilated and clasping base or winged petiole deeply pinnatifid into 5 to 9 retrorse lobes; corolla violet, 5 to 12 lines in diameter.

\section{* * Leaves opposite not auricled at base.}

2. N. maculata, Benth, Leaves lyrately pinnatifid into 5 to 9 short lobes, or the uppermost only 3-lobed; corolla white, with a violet spot at the top of each lobe, over an inch across.

3. IN. insignis, Dougl. Leaves similar to the last; corolla bright blue, its scales short and roundish, partly free.

4. IN. Menziesii, Hook \& Arn. Leaves less divided than the last; corolla from light blue to white and sprinkled with dots toward the center, its scales narrow and adherent by one edge.

* * Upper leaves often alternate, mostly longer than the peduncles, and slender-petioled, many only 3-5-lobed, one-sided.

5. IN. parviflora, Dougl. Slender and weak; corolla 2 to 5 lines across, light blue or white.

\section{ELLISIA, L.}

Calyx 5-parted. Corolla campanulate, short in proportion to the calyx; scales minute or obsolete. Stamens and style not exserted.

1. E, chrysanthemifolia, Benth. Stem 1 or $2 \mathrm{ft}$. high, erect, branched; leaves dissected into very many small and short divisions; flowers, small, white; capsule remarkable, viz.: the mostly four ordinary rough seeds enclosed between the placentr, while, between each placenta and the valve which it lines, is hidden a single thin, meniscoidal. smooth seed.

\section{PHACELIA, Juss.}

Calyx deeply 5-parted, the divisions usually narrow and similar; corolla from almost rotate to narrow-funnelform; commonly with appendages upon the inside of the tube in the form of 10 vertical plates, approximate in pairs between the bases of the filaments, or adnate to the filaments, one on each side. Stamens equally inserted low down or at the base of the corolla. Herbs, mostly hirsute or hispid and branched from the base; with simple or compound alternate leaves, or the lower opposite and more or less scorpioid infloresence. Corolla never yellow except in the throat. Ovules and seeds 4 in all except the last species. (See ADDEnda.) 
* Leaves simple and entire, or with a pair or two of similar and smaller leaflets or lobes.

1. P. circinata, Jacq. f. A span to a foot or two high from a stout root, hispid and the foliage strigose, either green, grayish or canescent, with a soft pubescence; leaves from lanceolate to ovate, acute, the lower tapering into a petiole and some bearing lateral leaflets; inflorescence in dense scorpioid hispid spikes, crowded; corolla dull or bluish white; filaments much exserted. - A very variable species; usually many stems from one root; some with large entire, ovate green leaves only.

2. P. Breweri, Gr. Foliage and habit similar to the last, but smaller and more slender, from an annual root; leaves seldom an inch long, many of them 3-5-parted, the lanceolate lateral lobes ascending; corolla smaller (scarcely 3 lines long), blue or violet; filaments not exserted.

\section{* * Leaves simple, rounded, cordate, lobed and serrate.}

3. P. malvæfolia, Cham. Stout, loosely branching, hispid with stinging hairs; leaves 2 inches or more in diameter; spikes solitary, or in pairs; corolla 3 to 6 lines long, dull white or bluish; stamens much exserted.

*** Leaves once to thrice pinnatifid or pinnately compound, oblong in general outline. Calyx bristly hispid, its lobes not rarely unequal. Annuals, the species difficult to dis. criminate.

4. P. tanacetifolia, Benth. Erect, 1 to $3 \mathrm{ft}$. high, roughish, hirsute or hispid; leaves 9-17-divided in narrow once or twice pinnately parted or cleft divisions, all sessile or nearly so; the scorpioid spikes clustered; the short pedicels erect or ascending; corolla usually of a dirty mottled white or bluish; stamens and style much exserted; calyx lobes not twice the length of the capsule.

5. P. ramosissima, Dougl. Straggling, somewhat viscid above; leaves pinnately 5 7-diviled or parted into linear pinnatifid-incised divisions; the short pedicels soon horizontal; stamens and style moderately exserted; calyx lobes more than twice the length of the globular capsule; flowers bluish.

6. P. ciliata, Benth. A span to a foot high; leaves rarely divided but incised or cleft and toothed; spikes simple or in pairs; stamens usually not surpassing the open corolla; calyx lobes ciliate with glandular bristles; corolla blue.

* * * Leaves entire, or the lower 1-2-lobed, not cordate, the veins parallel or converging, as in P. circinata; no glandular pubescence; calyx with long hairs; seeds more than 4.

7. P. divaricata, Gr. Diffusely spreading, a span or more in height; leaves ovate or oblong; style 2-cleft at the apex only; corolla violet, about 10 lines in diameter.

\section{EMIMENANTHE, Benth.}

Distinguished from Phacelia by the persistent ycllow or cream-colored corolla. 
1. E. pendulifora, Benth. A span to a foot high; somewhat viscid; leaves pinna. tifid; pedicels filiform, abont half an inch long, equaling the nodding corolla.

\section{5. romanzoffiA, Cham.}

Stamens unequal; style filiform. Low perennial herbs, with the aspect of saxifrages; the leaves mainly radical, round-cordate, or reniform, crenately 7-11-lobed, long petioled.

1. R. Sitchensis, Bong. Scapes weak, a span long, bearing several pink or purple, varying to white llowers; corolla veiny.

\section{ERIODICTYOIN, Benth.}

Calyx deeply 5-parted. Corolla funnel-form to salver-form. Stamens included.-Low shrubs; the leaves alternate, of rigid coriaceous texture, the finely reticulated veinlets conspicuous on a fine woolly ground, at least underneath, their margins beset with rigid teeth.

1. E. glutinosum, Benth. (Mountarn Balm, or Yerba Santa.) Smooth, glutinous with a resinous exudation, 3 to $5 \mathrm{ft}$. high; leaves lanceolate, 3 to 6 inches long; cymes in a naked panicle; corolla tubular, funnel-form, violet or nearly white, half an inch long.

E. tomentosum, Benth., grows farther down the coast. It is larger with smaller almost salver-form flowers; densely villous.

\section{ORDER 40. BORRAGINACPZF.}

Mostly roughly pubescent herbs, with alternate entire leaves without stipules, scorpioid inflorescence, and perfectly regular 5-androus flowers; the ovary of 4 lobes or divisions around a central style, ripening into seed-like nutlets. Calyx free, 5-parted or 5-cleft, persistent. Corolla with a 5-lobed limb, commonly imbricated in the bucl. Stamens distinct, inserted in the tube or throat of the corolla alternate with its lobes. The one-sided and coiled apparent spikes or racemes straighten as the blossoms develop. All our species except the first belong to the true Borrage Tribe.

\section{* Fruit not prickly.}

Corolla with plaited sinuses; stigma sessihn..................Fliotropium. I Corolla yellow. Bristly-hispid plants....................... Amsinclsia. 2 Corolla white...................................... Eritrichium. 3

* * The nutlets prickly, bur-like.

Flowers sky-blue (rarely white) in bracteate racemes........... Echinospermum. 4 Flower purple, blue and violet in a peduncled raceme............ Cynoglossum. 5 Flowers minute; nutlets winged, or boat-shaped...............Pectocarya. 6 


\section{HELIOTROPIUM, Tourn.}

Corolla with plaited sinuses. Filaments short or none; anthers connivent and some. times cohering. Style entire or none; stigma a fleshy ring or the edge of a peltate or umbrella-shaped disk. Fruit dry, splitting into 4 nutlets.

1. II. Curassavicum, L. A smooth and somewhat glaucous succulent herb with spreading or prostrate stems; leaves oblanceolate, an inch or two long; flowers crowled, white or blue; stigma sessile, flat-topped. Blackens in drying.

\section{AMSINCKIA, Lehm.}

Corolla salver-form, or somewhat funnel-form, more or less plaited in the bud at the sinuses, with the tube exceeding the calyx, lobes rounded. Filaments short. Style filform; stigma capitate-2-lobed. Nutlets ovate-triangular. Hispid annuals with oblong. ovate to linear leaves, and yellow flowers in at length loose scorpioid spikes or racemes, without bracts, except sometimes the lowest.

\section{* Nutlets rough, the back convex.}

1. A. spectabilis, Fisch. \& Mey. Erect, a span to a foot high; leaves mostly linear; tube of the bright orange-yellow corolla, two or three times the length of the linear, rusty-hispid calyx, nearly half an inch long; the throat enlarged, and the expanded limb a third to half an inch in diameter.

2. A. intermedia, Fisch. \& Mey. Erect, usually a foot or two high; leaves linear or only the lower lanceolate; corolla bright yellow, 3 or 4 lines long; its tube a little surpassing the calyx-lobes; the limb 2 or 3 lines in diameter.

3. A. lycopsoides, Lehm. Loosely branched, soon spreading, sometimes decum. bent, sparsely hispid with bristles, which on the leaves have conspicuous pustulate bases; leaves from lanceolate to ovate, the margins usually undulate; upper flowers mostly bractless; corolla light yellow, about 4 lines long; the throat little enlarged; the limb 2 or 3 lines in diameter. Passes into

Var. bracteosa, Gr., a smaller-flowered decumbent form, with most of the flowers bracteate.

* * Nutlcts nearly flat on the back, coarsely granulate.

4. A. tessellata, Gr. About a foot high, rather stout, coarsely hispid, the bristles of the calyx rusty; corolla orange-yellow, 3 or 4 lines long, the throat plaited, the tube rather longer than the obtuse calyx-lobes; nutlets broadly ovate, thickly covered with warty granulations closely fitting like the blocks of a pavement.

$$
\text { * * * Nutlets at maturity, whitish, smooth and polished. }
$$

5. A. vernicosa, Hook \& Arn. Sparsely bristly; leaves linear to ovate-lanceolate; corolla light yellow, 4 or 5 lines long, and the limb narrow; nutlets shaped like a grain of buckwheat. 
Var. grandiflora, Gr. Robust, more hispid and large flowered, the limbs broader; calyx lobes often combined, so as to appear as 3 or 4 .

\section{ERITRICHIUM, Schr.}

Most obviously distinguished from Amsinckia and the nearer Echinospermum by its usually smaller white flowers, with shorter corolla tube. The species difficult of determination.

1. E. Californicum, DC. The slender stems decumbent, a span or more long; the leaves narrowly linear; stems flowering from near the base; flowers almost sessile, mostly with leaves or bracts, at length scattered; the corolla only a line long; calyx open in fruit. Passes into

Var. subglochidiatum, Gr. Slightly succulent; lower leaves inclined to spatulate, nutlets somewhat barbed. Wet ground.

2. E. Scouleri, A.DC. Slender, erect a span to a foot high; leaves narrowly linear (1 or 2 inches long); flowers in geminate or sometimes paniculate slender naked spikes, most of them bractless; pedicels not more than a line long; calyx erect in fruit; corolla surpassing the calyx, the limb almost rotate, 2 to 5 lines in diameter.-Seems to pass into the next.

3. E. Chorisianum, DC. At first erect, soon spreading or decumbent; larger leaves, 2 to 4 inches long; flowers in lax, usually solitary racemes, many of them leafy-bracted; pedicels sometimes filiform and 2 to 9 lines long; corolla more funnel-form, its limb 3 to 5 lines in diameter.-This may be a wet ground form of the last, which grows on dry ground.

4. E. fulvum, A.DC. A span to a foot high, slender branched from a leafy base, pubescent; leaves linear, or the lower lanceolate or spatulate; spikes at maturity nearly filiform, bracteate only at the base; calyx, etc., densely clothed with rusty or fulvous hairs; calyz deciduous, only the lower part remaining under the fruit; corolla limb 2 lines across.

5. E. canescens, Gr. Stouter and larger than the last; the pubescence whitish. not rusty; leaves linear; calyx hardly deciduous.

6. E. oxycaryum, Gr. May be known by the solitary ovate-acuminate, smooth, shining nutlet enclosed in the persistent bur-like calyx; corolla 2 lines wide.

\section{ECHINOSPERMUM, Swartz.}

Calyx lobes spreading or reflexed in fruit. Corolla short, salver-form, and with conspicuous arching crests at the throat. Short filaments, style, etc., as in Eritrichium. Nutlets with barbed prickles.

1. E. floribundum, Lehm. Rather strict, $2 \mathrm{ft}$. or more high, or sometimes smaller; leaves from oblong to linear-lanceolate; racemes numerous, usually geminate; the tri- 
angular nutlets armed with prickles on the margins; limb of the rotate corolla 2 to $\mathbf{5}$ lines in diameter, blue, rarely white.

\section{CYNOGLOSSUM, Tourn.}

Chiefly distinguished from the preceding by the broad large leaves, the bractless racemes and the nutlets clothed over the whole back with stout barbed prickles.

1. C. grande, Dougl. About $2 \mathrm{ft}$. high, pubescence soft; radical and lower stem leaves ovate oblong, usually rounded or cordate at the base, long petioled; panicled racemes or eymes small, on a long naked terminal peduncle; corolla tube exceeding the calyx; its limb blue to violet, with usually purple crests; 3 to 5 lines wide.

\section{PECTOCARYA, DC.}

Structure of the minute white flowers similar to the preceding; nutlets widely spreading in pairs, horizontal, oblong or almost linear, surrounded by an incurved wing-like border which is toothed, the apex beset with hooked bristles.

1. P. penicillata, A. DC. Very slender, diffusely branching, spreading, with narrow linear leaves, and small flowers scattered the whole length of the stem, on very short pedicels; nutlets only a line long.

\section{Order 41. CONVOLVULACEZF.}

Herbs, usually twining or trailing, with alternate leaves (or scales) and regular perfect flowers; the stamens as many as the lobes or angles of the corolla and alternate with them (5, rarely 4); the free persistent calyx of mostly distinct imbricated sepals; ovary 2-3-celled; capsules generally globular; seeds 1 to 4 . Inflorescence axillary.

Corolla plaited in the bud; style single................... Convolvulus. I

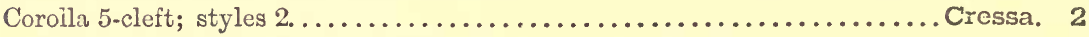
Twining parasites, leafless, yellowish.................................. 3

\section{CONVOLVULUS, L.}

Corolla campanulate or short and open funnel-form, with a 5-angulate or obscurely 5-lobed border, deeply plaited down the sinuses in the bud. Stamens included. Style filiform; stigmas 2, in ours flat, from linear to oval. (See ADDENDA.)

\section{* A pair of bracts close to the calyx, enveloping it.}

1. C. Soldanella, L. Maritime, low, smooth; stems a foot or less in length, trailing; leaves reniform entire or obscurely angulate-lobed, an inch or two broad, long petioled; corolla pink, purplish, or nearly white. 
2. C. occidentalis, Gr. Mostly smooth; stems twining several feet high; leaves from broadly ovate-triangular with a deep and narrow basal sinus to narrowly lanceolatehastate; the posterior lobes often 1-2-toothed; peduncle elongated, not rarely 2-flowered within the bracts; these ovate or rarely oblong, commonly surpassing the enclosed calyx; corolla white or pinkish, 1 to $1 \frac{1}{2}$ inches broad; stigmas linear.

3. C. Californicus, Choi. Minutely and rather densely pubescent, a span or less high, or with trailing stems a foot long; leaves from ovate or obovate and obscurely hastate to triangular-hastate, the basal lobes sometimes 1-2-toothed, long-petioled; peduncles shorter than the petiole; bracts oblong or oval, about equaling the sepals, or shorter; corolla white, cream-color or flesh-color, $1 \frac{1}{2}$ to 2 inches long.

4. C. villosus, Gr. Densely silky-villous or woolly; corolla cream colored, an inch long.

* * No calyx-like bracts; sometimes a pair of leaves close under the flower or a pair of Lracts at some distance below it.

5. C. luteolus, Gr. Stems twining several feet long; leaves triangular-hastate or sagittate, the basal lobes sometimes 2-lobed; peduncles bearing a pair of linear or lan. ceolate entire bracts, a little below the flower; a second flower oceasionally from the axil of one of them; corolla pale yellow or purplish, an inch or more in length; stigmas linear.

\section{CRESSA, L.}

Corolla deeply 5-cleft; the oblong or ovate lobes more than half the length of the somewhat campanulate tube. Stamens and the 2 distinct styles exserted. Stigmas capitate.

1. C. Cretica, L. A span or two high, silky-villous and hoary; leaves very numerous, 2 to 4 lines long, almost sessile; flowers acssile or nearly so in the upper axils; corolla 2 or 3 lines long, white.-On saline or alkaline soil.

\section{CUSCUTA, Tourn. DODDER.}

Calyx 5-4-cleft or parted. Corolla campanulate or short-tubular, the spreading limb 5-4-parted. Styles in our species 2, distinct. Seeds germinating in the soil, but the thread-like, branching, leafless, yellowish or reddish twining stems becoming parasitic on the bark of herbs or small shrubs; being attached by means of suckers. Flowers small, cymose or densely clustered, white or whitish.

\section{* Capsule depressed-globose.}

1. C. Californica, Choisy. Flowers pedicelled in loose few-flowered cymes; lobes of the calyx acute; lobes of the corolla lanceolate-subulate, delicate white; no scales below the stamens.

Var. breviflora, Engel. Flowers scarcely over a line long; calyx lobes equaling the coro'la-tube. 
Var. longiloba, Engel. Flowers $1 \frac{1}{2}$ to $2 \frac{1}{2}$ lines long; calyx-lobes often with recurved tips; capsule mostly only 1 -seeded, enveloped by the withered corolla.

* * Capsule pointed, capped or enveloped by the withered corolla.

2. C. salina, Engel. Flowers $1 \frac{1}{2}$ to $2 \frac{1}{2}$ lines long delicate white; corolla lobes often overlapping, denticulate; capsule surrounded but not capped by the corolla, usually 1-seeded.-Growing in saline marshes, usually on Salicornia.

3. C. subinclusa, Dur. \& Hilg. Flowers sessile or nearly so (at length in large clusters), $2 \frac{1}{2}$ to 4 lines long; lobes of the corolla short, the tube somewhat urn-shaped, only partly covered by the fleshy, usually reddish calyx. - The most common species growing on coarse herbs and shrubs.

\section{Order 42. SOLANACE互.}

Herbs or shrubs, with alternate leaves and no stipules, regular 5-merous flowers on bractless pedicels, a single style and a 2-celled ovary; the fruit a many-seeded berry or capsule.

This small order of, perhaps, not more than a dozen species west of the Sierra Nevada, and less than 70 in North America, is remarkable for the diversity of properties exhibited by its members, and the almost universal use by man of several of its species. At first view, the elassification seems absurd which puts fiery Cayenne pepper and insipid egg plants, the wholesome tomato and deadly night-shade, nutritious potatoes and poisonous tobacco together in one family. A careful examination shows that these seemingly very different plants are much alike after all. The four most important plants of this orderpotato, tobacco, red or Cayenne pepper, and tomato-are natives of tropical America, and were consequently not used in the old World before the sixteenth century. The following ornamental plants of the order are common in cultivation: Jerusalem Cherry (Solanum Pseudo-Capsicum), a small shrub, with red berries; Jasmine Solanum (S. Jasminoides), a shrubby climber, with a profusion of nearly white blossoms a little smaller than those of the potato; the well-known Matrimony Vine (Lycium vulgare); Tree Datura or Stramonium (Datura arborea), with hanging flowers six or seven inches in length; Cestrum, a shrub with drooping tubular red flowers in terminal bunches; and Petunia, with funnel-form corollas of various colors.

Solanum Xanti, Gray, grows along the coast from Santa Barbara southward, and has been reported from Lake County. It is more herbaceous than S. umbelliferum, and may be distinguished with the aid of a lens by its simple glandular hairs, instead of the branching hairs of the latter species.

Physalis or Ground Cherry may be found in cultivated ground. Its berries are enclosed by an inflated calyx.

Datura Meteloides, DC., grows on the Salinas River and southward. The flowers are white or violet tinged, and 6 to 8 inches long, with a wide border; the capsule nodding. 


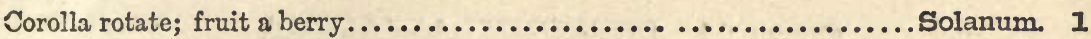
Corolla funnel-form; capsule large, spiny..$\ldots \ldots \ldots \ldots \ldots \ldots \ldots \ldots \ldots$. Datura. 2 Corolla funnel-form; capsule smooth..........................Nicotiana. 3

\section{SOLANUM, Tourn.}

Lobes of the corolla valvate in the bud. Filaments short; anthers usually conniving. Style elongated.

\section{* Corolla small white; deeply 5-cleft.}

1. S. nigrum, L. (BLACK NightSHADE.) Widely branching; leaves usually ovate and sinuate toothed; flowers in umbellate clusters; berries black. Variable.

Var. Douglasii, Gr. Leaves apt to be coarsely toothed; flowers sometimes half an inch broad.

\section{* Corolla large, blue, 5-angled.}

2. S. umbelliferum, Esch. Somewhat shrubby; flowers in umbel-like clusters, violet-blue to rarely white, about 9 lines broad. A variable species similar to $S$. Xanti, which is less shrubby and has larger flowers, a common species farther south.

\section{DATURA, L. StramonidM.}

Calyx prismatic, partly deciduous. Corolla with ample 5-pointed limb. Style long; stigma 2-lipped. Capsule spiny.

1. D. Stramonium, L. Smooth, green; corolla white, about 3 inches long; capsule beset with short, stout prickles, the lower shorter.

2. D. Tatula, L. Stem reddish-purple; corolla pale violet; prickles about equal.

3. D. quercifolia, HBK. Green; corolla violet-tinged; prickles flattened, unequal, some an inch long.-Lower Russian River.

\section{Nicotiana, Tourn. Toвacco.}

Calyx campanulate or oblong, persistent. Corolla commonly funnel-form, the limb plaited. Style long; stigma capita te, somewhat 2-lobed.-Very viscid herbs.

1. N. rustica, L. Leaves petioled, ovate, or the lower slightly cordate; corolla short and broad, dull white, less than an inch long.

2. N. Bigelovii, Wat. Leaves oblong or oblong-lanceolate, only the lower ones petioled, these scarcely exceeding 6 inches long; corolla nearly salver-form with tube $1 \frac{1}{2}$ inches long, the limb an inch or more wide, its lobes acute.

3. N. attenuata, Torr. (SLENDER ToBacco.) Leaves petioled, the lower ovate or oblong, the upper lanceolate to linear lanceolate; calyx teeth short; corolla greenish white, salver-form, an inch or more long, and a half an inch or less across. Slender plants 3 or 4 feet high in cultivated ground.

4. IN. glauca, Graham. (ToBacco TrEe.) A small tiee, commonly cultivated; smooth, glaucous leaves long-petioled; tubular corolla greenish jellow, an inch or more long. 


\section{ORDER 26. SCROPIULARIACE正.}

A corolla more or less bilabiate, with the lobes imbricated in the bud; didynamous or diandrous stamens; a single style and a 2-celled ovary and capsule mark this large order. In Pentstemon there is a fifth rudimentary stamen. Verbascum has five perfect stamens.

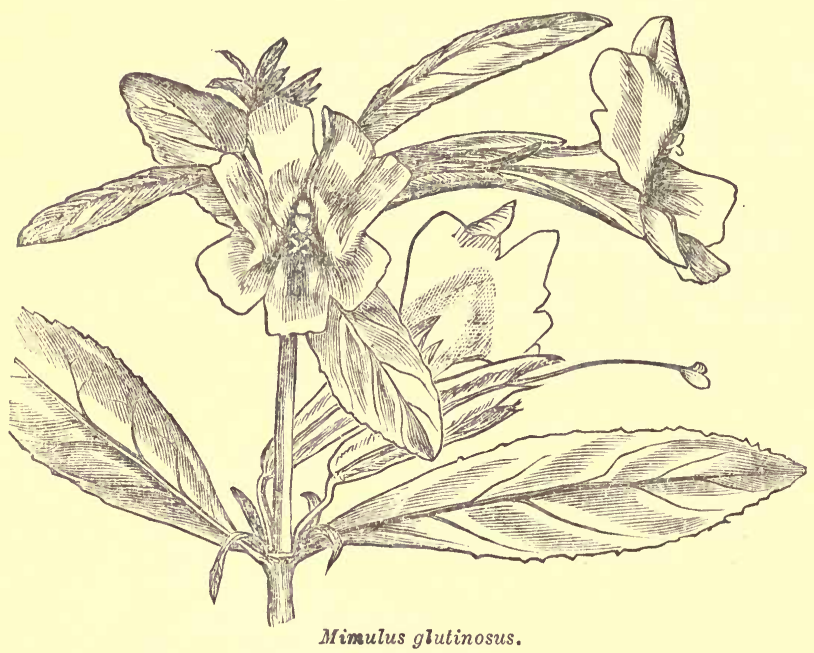

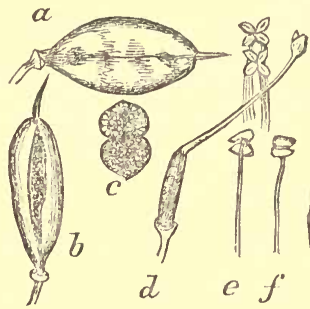

a. Ripe capsule of $\mathrm{Mi}$ mulus luteus. $b$. The same seen edgewise bursting open. c. A cross section of the same, showing the placentw and seeds. d. Pistil of Mimulus luteus. e. Front view of one of the anthers. $f$. Back view of

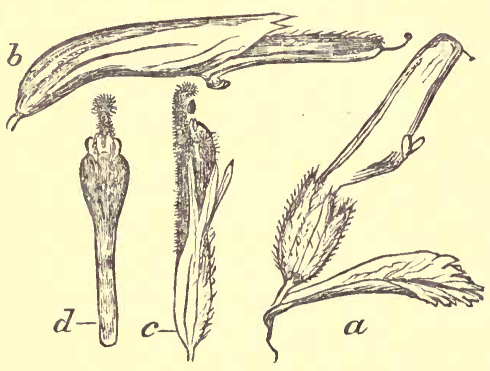

the same. Above these are the stamens of $\mathrm{Mi}$ mulus glutinosus united in pairs.

a. Single flower and bract of Pedicularis densiflora (galea flattened laterally, the pistil protruding; the lower lip of 3 small lobes, 2 of which are shown). $b$. A single flower of Castilleia. c. Single flower of Orthocarpus purpurascens. d. Front view of the same, with calyx removed. The lower lip (anterior or front part of the flower) 3-lobed, the galea beaked and surpassing the stigma.

This large order, numbering nearly 2,000 species, is remarkable for the great beanty of its flowers, and for the impartial distribution of its species over the whole worll. Over 300 species, belonging to 37 genera, are natives of the United States. About 75 species grow east of the Mississippi, and about 100 west of the Sierra Nevada in this State. The 
most important American genera are Pentstemon, 75 species, found, with one exception, only in North America, and mostly within the limits of the United States between the Rocky Mountains and the Sierra Nevada; Mimulus, represented in other countries, but most largely in North America, where there are 30 species, about two thirds of which grow in California, west of the Sierra Nevada, only 2 species reaching the Atlantic States; Orthocarpus, 24 species, all North American, except one, and west of the Mississippi, 16 belonging to California; Gerardia, 24 species, mostly in the Atlantic States, and none reaching the Rocky Mountains; Castilleia, 23 species, 2 Asiatic, 3 in the Atlantic States, and 8 or 9 in California; Pedicularis, a large genus, mostly in the arctic regions and on high mountains of the temperate zone, $2 S$ American species; Collinsia, 15 species, all Californian, except two, which grow in the Mississippi Valley. Several showy species of shrubby Veronicas are cultivated. This large genus, numbering 40 species in New Zealand alone, is represented in the United States by only a few obscure herbs. Digitalis, commonly cultivated under the name of Foxglove, has run wild about Humboldt Bay and in the Willamette Valley.

Many plants belonging to the genera Pentstemon, Collinsia, and Mimulus are cultivated on account of their beautiful flowers. Pentstemons are mostly confined to hilly or mountainous districts. Collinsias grow everywhere. Most species of Mimulus prefer moist places, but the only shrubby species, $M$. glutinosus, grows on dry, rocky hillsides.

Two species of Verbascum (Mullein) are found in the State, but probably not within our limits; $V$. Thapsus, L., with woolly decurrent leaves and $V$. virgatum, Withe., distinguished by nearly smooth not decurrent leaves and violet bearded flaments.

* Leaves mostly alternate; corolla personate.

Corolla spurred at base................................................ I

Corolla gibbous at base $\ldots \ldots \ldots \ldots \ldots \ldots \ldots \ldots \ldots \ldots \ldots$. Antirrhinum. 2

* Leaves opposite or whorled.

Corolla erect; the anterior lobe reflexed, the other 4 erect, a scale in the throat on the upper side................................. Scrophularia. Corolla declined, the middle lower lobe infolding the stamens and style... Collinsia. 4 Carolla with a fifth sterile filament on the upper side..............Pentstemon. 5 Stigma 2-lipped or disk-like.................................mulus. 6

$$
\text { * * Corolla rotate or short-campanulate. }
$$

Calyx 5-toothed; corolla campanulate........................... Iimosella. 7 Calyx 4-parted; corolla 4-lobed, rotate......................... Veronica. 8

* * * Corolla tubular; the upper lip erect or incurved, laterally compressed, usually en. closing the ascending stamens.

Corolla narrow with almost obsolete lower lip............................... 9 Corolla with saccate lower lip of 3 lobes...................... Orthocarpus. 10 
Lips of corolla, both short; the lower 3 -crenulate.............. Cordylanthus. II Upper lip of the corolla arched; many large radical leaves ............ Pedicularis. 12

\section{IINARIA, Tourn.}

Calyx 5-parted. Corolla with the throat nearly closed; the base in front (below) prolonged into a spur.

1. 工. Canadensis, Dum. (Toad Flax.) Sinooth; leaves linear, alternate on the erect flowering stems, but smaller and broader ones often opposite or whorled on the procumbent shoots; flowers blue in a terminal raceme.

\section{ANTIRRHINUM, Tourn. SNaPdragon.}

Like Linaria, except that the corolla has a saccate protuberance instead of a spur. In ours the upper lip is spreading and the lower lobes deflexed.

1. A. glandulosum, Lindl. Glandular and viscid; leaves lanceolate, mostly sessile; flowers in a dense spike or raceme, half an inch or more long, pink with yellowish palate.

2. A. vagans, Gr. Very diffuse, often glandular, branchlets frequently prehensile; leaves short, lanceolate to ovate; flowers scattered, purplish blue, half an inch long.

Var. Bolanderi, Gr. Has broader and thinner leaves, those on the prehensile branch. lets orbicular.

3. A. Ereweri, Gr. Has smaller flowers, only 3 lines long; style strongly deflexed.

\section{SCROPHUIARIA, Tourn. Figwort.}

Calyx deeply 5-cleft, the lobes broad. Corolla short, with an oblong tube unequally 5-lobed, 4 erect, the two upper the longer. Stamens 4 , inserted in pairs, low down on the corolla tube, a rudiment of the fifth stamen in the form of a scale above. Coarse herbs, with inconspicuous flowers.

l. S. Californica, Cham. Nearly smooth, 2 to $6 \mathrm{ft}$. high, with deltoid or truncateovate doubly toothed opposite leaves; flowers small greenish or lurid red (rarely yellow) in a terminal thyrsus.

\section{COLLINSIA, Nutt.}

Calyx deeply 5-cleft. Corolla with the tube gibbous or saccate on the upper side, commonly declined, conspicuously bilabiate; the upper lip 2-cleft, and its lobes recurving; the lower 3-lobed and larger, its side lobes pendulous-spreading, the middle one folded into a keel-shaped sac and including the declined stamens and style. Stamens in pairs, with long filaments, anthers round-reniform. A gland at the base of the corolla on the upper side answers to the fifth stamen. - Beautiful annuals with simple opposite or whorled leaves, all but the lower sessile; pedicels solitary or whorled in the axils of leaves which diminish to small bracts above. 


\section{* Flowers short-pediceled or nearly sessile, verticillate.}

1. C. bicolor, Benth. A foot or more high; leaves oblong-lanceolate, the upper usually ovate-lanceolate and sessile by a nervose veined base; pedicels shorter than the acute lobes of the calyx; the lower lip or the corolla violet or rose-purple and the upper paler to nearly white; the saccate throat very cblique to the true tube, fully as broad as long; gland short.-The most showy species, with flowers nearly an inch long.

2. C. tinctoria, Hartw. Foliage, etc., like the preceding; generally more viscid. pubescent; flowers almost sessile; corolla yellowish, cream-color, or white, usually with purple dots or lines; upper lip very short.-East side of Sacramento Valley.

3. C. bartsiæfolia, Benth. Puberulent and somewhat glandular; leaves from ovate. oblong to linear: flower-whorls 2 to 5 , rarely only one; the lateral lobes of the lower lip emarginate or obcordate; gland elongated. Flowers nearly as large as the preceding, purplish, pale violet, or whitish; upper lip with a transverse callosity at the origin of the limb.

4. C. Greenei, Gr. Upper lip of the violet purple corolla about half the length of the lower, crested below with a pair of callous teeth on each side connected by a ridge. Corolla 5 lines long.-Lake County.

\section{* * Flowers on slender pedicels, solitary or umbellate-whorled.}

6. C. sparsiflora, Fisch. \& Mey. Slender; upper leaves linear-oblong or linearlanceolate, merely opposite or the upper minute floral bracts in threes; pediccls solitary in the axils, longer or shorter than the flower which is 4 to 8 lines long; corolla mostly violet; the upper lip and the middle lobe of the lower commonly yellowish and purpledotted; calyx usually purple-tinged.

7. C. parviflora, Dougl. Low, at length diffuse about a span high; the blue, or partly white flowers solitary or 2 to 5 in a whorl, 2 to 4 lines long; stigma cleft, gland capitate, short-stipitate.

\section{PENTSTEMON, Mitch.}

Calyx 5-parted. Corolla with a conspicuous mostly elongated or ventricose tube; the limb more or less bilabiate; upper lip 2-lobed; the lower 3-cleft, recurved or spreading. The conspicuous sterile filament strongly marks the genus, remarkable for its many beautiful species. (See ADDENDA.)

1. P. Menziesii, Hook. Tufted at the woody base, a span to a foot high; leaves oval or ovate, a half to an inch long; corolla about an inch long, pink-red; anthers with the diverging cells long-woolly. Mt. St. Helena, Mrs. Mr. L. Swett.

2. P. corymbosus, Benth. A foot or two high, soft-pubescent or nearly smooth, leafy to the tip; corolla scarlet, an inch long; anthers smooth; steril filament, bearded down one side.

3. P. breviflorus, Lindl. 3 to $6 \mathrm{ft}$. high, with long, slender, flowering branches; corolla yellowish with flesh-color, striped within with pink, about lialf an inch long; the opper lip beset with long viscid hairs; sterile fllament naked. 
4. P. Lemmoni, Gr. Is smaller and may be distinguished from the last by its yellow bearded sterile filament.

5. P. heterophyllus, Lindl. Stems 1 to $5 \mathrm{ft}$. high from a woody base; leaves lanceolate or linear; corolla an inch or more in length, ventricose, rose-purple or pink changing to violet, an inch or more in length. Difficult to distinguish from the next.-Coast Iiange.

6. P. azureus, Benth. Usually smaller than the last; the larger corolla azure blue changing to violet; the base sometimes reddish; the expanded limb sometimes an inch broad. - Sierra Nevada.

\section{MIMUIUUS, L.}

Calyx mostly plicately $\bar{u}$-angled. Corolla funnel-form, with the included or rarely exserted tube bilabiatcly 5-lobed; the lobes roundish, more or less spreading or the upper turned back; a pair of ridges running down the lower side of the throat. The anthers often approximate in pairs, their cells divergent. The lobes of the stigma commonly petaloid-dilated or peltate-funnelform.-Flowers axillary on simple peduncles; commonly showy.

1. M. tricolor, Lindl. Stem, when beginning to flower, only a quarter of an inch high, at length 3 inches. Corolla about $1 \frac{1}{2}$ inches long, with a long exserted slender tube, a short funnelform throat, and similar nearly equal lobes; pink, with a crimson spot on the base of each lobe, a yellow stain along the lower lip. Leaves sessile.

2. M. Douglasii, Gr. Similar to the last; leaves contracted into a petiole; lower lip of the corolla much shorter than the erect upper one or even obsolete; the throat more ample. Stem from a $\frac{1}{4}$ to 6 inches high.

3. M. glutinosus, Wendl. A brittle-stemmed shrub, 2 to $6 \mathrm{ft}$. high, with thick glutinous-sticky leaves and mostly buff or salmon-colored flowers, but running into varieties with red, red-brown, or scarlet flowers.

4. IM. cardinalis, Dongl. Villous, with viscid hairs; the large leaves ovate, the upper often connate; corolla frequently 2 inches long; the tube hardly exceeding the long calyx, the limb very oblique, scarlet.-Along water courses.

5. M. luteus, L. Mostly smooth, varying greatly in size from a foot to even $4 \mathrm{ft}$. high; leaves ovate oval or cordate; corolla deep yellow, usually spotted within, and the base of the lower lip blotched with brown-purple, from 1 to 2 inches long. Moist ground.

6. M. inconspicuus, Gr. Smouth, 2 to 7 inches high; the ovate or lanceolate leaves sessile, a half inch or less long; corolla 5 lines long, yellow or rose-color; calyx teeth very short.

7. M. moschatus, Dougl. (Musk Plant.) Very villous and usually musk-scented; stems spreading and creeping; flowers yellow.-Our form is chiefly

Var. longiflorus, Gr., with very clammy leaves and flowers an inch long, scarcely musky. 
8. M. pilosus, Wat. A span to a foot high, much branched, soft, villous and Blightly viscid, many flowered from near the base; leaves lanceolate to narrowly oblong, sessile, entire; calyx tube not prismatic; corolla yellow, obscurely bilabiate, 3 or 4 lines long, usually a pair of brown-purple spots on the lower lobe.

\section{LIMOSELLA, L. MUdWort.}

Calyx campanulate. Corolla rotate-campanulate, nearly regular. Style short; stigma thickish.-Diminutive annuals, with narrow fleshy leaves in clusters around the 1-flowered scapes. Flower small, white or purplish.

1. I. aquatica, L An inch to a span high, growing in brackish mud or in fresh water.

\section{VERONICA, I.}

The lower lobe and sometimes the lateral ones of the rotate corolla sometimes smaller than the others. Stamens 2, one on each side of the upper lobe of the corolla. Capsules compressed. Flowers small (a line or two broad), in racemes or spikes, or solitary in the axils; blue, purplish, or white.

1. V. Americana, Schw. Stems a span to two feet long; leaves ovate or oblong. serrate, rather succulent, short-petioled, an inch or two long, opposite. Flowers in axillary racemes, bluish, with purple stripes. Common in damp places.

2. V. peregrina, L A span or more high, all the upper leaves alternate, linearoblong; flowers minute, in the axils of the leaves, and mostly narrow bracts; capsule obcordate.

\section{CASTILLEIA, Mutis. Painted-Cup.}

Calyx tubular, more or less cleft in front or behind, or both; the lobes 2 and lateral, or 4. Corolla tubular, laterally compressed, especially the long upper lip (galea); the lower lip very short or minute, 3 -toothed, and somewhat saccate below the short teeth; the tube usually inclosed in the calyx. Stamens 4, inclosed in the galea; anthers 2-celled, the long cells unequal, the outer fixed by the middle, the inner ones smaller, pendulous. Style long; the capitate stigma sometimes 2-lobed. Herbs, sometimes woody at the base, with mostly alternate, sessile leaves, the flural ones or their tips, as well as the calyx lobes, commonly petaloid and colored red, yellow, or white. Flowers in terminal, simple, leafy spikes.

1. C. affinis, Hook. \& Arn. Annual; a foot or two high; leaves narrowly lanceolate, entire; the upper floral bracts usually broader, the apex toothed, red; spike with scattered, frequently pedicellate flowers below; calyx red; an inch long, its front fissure hardly twice as deep as the back one, the narrow lobes acutely 2-cleft; corolla 1 to $1 \frac{1}{2}$ inches long, exserted so as to expose the callous lip; the galea about equal to the tube, yellowish or tipped with red.

2. C. latifolia, Hook. \& Am. Perennial (as are all the following!; branching from 
the base, 1 or $2 \mathrm{ft}$. high, villous-hirsute and viscid; leaves oval, obtuse, lalf an inch or more long, some above 3-5-lobed and red; calyx 2-cleft to the middle, the lobes entire or emarginate, almost equaling the corolla; corolla 8 lines long, the short teeth of the lip inflexed.

3. C. parviflora, Bong. A span to $2 \mathrm{ft}$. high, villous-hirsute above; leaves variously cleft into linear or lanceolate lobes, or sometimes the cauline are mainly entire and narrow; calyx lobes oblong and 2-cleft at the apex or to below the middle; corolla an inch or less long; only the upper part of the narrow galea exserted-A variable species. As in the preceding species, the bracts and calyx are usually colored red or crimson, but sometimes varying to yellow or even white.

4. C. miniata, Dougl. Commonly $2 \mathrm{ft}$. high, strict, often slender; leaves lanceolate or linear-lanceolate, almost always entire, the broad floral ones of the close spike sometimes incised or 3-cleft, usually bright red, rarely whitish; calyx lobes lanceolate, acutely 2-cleft; corolla over an inch long, exserted, exposing the short ovate teeth of the lip.

5. C. foliolosa, Hook. \& Arn. Densely white-woolly, the matted hairs loosened with age; many-stemmed from a woody base; leaves narrowly linear, an inch or less long, crowded below and fascicled in the axils.

\section{ORTHOCARPUS, Nutt.}

Chiefly distinguished from Castilleia by the upper lip of the corolla (galea) which but little, if at all, surpasses the usually more conspicuous and inflated 1-3-saccate lower lip.

§1. CASTILlEIOIDES, Gr.-Lower lip of the corolla simply or somewhat triply saccate, and bearing 3 conspicuous teeth; the galea broadish or narrow; stigma capitate; anthers all 2-celled; bracts with colored tips.

* Filaments smooth; galea straight or nearly so, naked, narrow; the lip moderately ventricose; its teeth erect.

1. O. attenuatus, Gr. Slender, strict, a span or two high, mostly simple; leaves linear and attenuate, often with a pair of filiform lobes; spike slender; lower flowers scattered; bracts with slender lobes barely white-tipped; corolla narrow, half an inch long, white or whitish; narrow teeth of the purple-spotted lip nearly equaling the galea.

2. O. densiflorus, Benth. Erect or diffusely branched from the base 6 to 12 inches high; spike dense, many flowered, at length cylindrical, or lowest flowers rather distant; bracts 3-cleft, about equaling the flowers, their linear lobes purple and white; corolla from 8 to 12 lines long, the tips usually purplish, the teeth of the lip shorter than the galea.

3. O. castilleioides, Benth. At length diffuse and corymbosely branched; leaves from lanceolate to oblong, usually laciniate; the upper and the bracts cuneate-dilated and incisely cleft, green or the obtuse tips whitish or yellowish; spikes dense, short and thick: corolla ncarly an inch long, dull white or purplish-tipped; lip ventricose-dilated. 
* Filaments pubescent; galea densely red-bearded; the obtuse tip incurved.

4. O. purpurascens, Benth. Bracts and corolla usually crimson to rose-color. Distinguished by the bearded, hooked galea, and large stigma.

§2. Triphysaria, Benth. - Lower lip of the corolla conspicuously 3-saccate, and very much larger than the slender galea, its teeth small, the tube filiform; stigma capitate, sometimes 2-lobed; bracts like the leaves and not colored.

5. O. pusillus, Benth. Small and weak or diffuse, branched from the base, 3 or 4 inches high; leaves 1-2-pinnatifid, and bracts 3-5-parted into filiform divisions; flowers scattered, inconspicuous, shorter than the bracts; corolla purplish, 2 or 3 lines long; lip moderately 3-lobed; galea soon exposing the stamens.

6. O. floribundus, Benth. Slender, erect, 4 to 12 inches high; spike many-flowered, dense above; corolla white or cream-color, half an inch long; the tube twice the length of the calyx; stamens about the length of the soon open galea; the lip with 3 divergent oval sacs, their scarious teeth erect.

7. O. erianthus, Benth. Erect, a span or more high, much branched, pubescent; corolla sulphur-yellow, with the slightly falcate galea brown-purple; tube 6 to 8 lines long, filiform, densely pubescent, thrice the length of the calyx; the lip of 3 globularinflated sacs, 1 to 2 lines long; the galea subulate, inclosing the stamens more strictly than the preceding.

Var. roseus, Gr. Corolla rose-purple, shorter.

8. O. faucibarbatus, Gr. Nearly smooth, less branched, and leaves with coarser divisions than the last; corolla with smaller sacs and less beard within the lip; the straight galea pale.

9. O. lithospermoides, Benth. Hirsuto above; stem 4 to 12 inches high, strict, mostly simple, very leafy; bracts of the dense many-flowered spike about equaling the flowers; corolla an inch or less long, cream-color, often turning pale rose-color; sacs 3 lines deep; the teeth inconspicuous; anthers 2-celled.

\section{CORDYLANTHUS. Nutt.}

Calyx of an anterior and a posterior leaf-like division, or the former wanting. Corolla tubular, a little enlarging upward; the lips short and of nearly equal length; the lower very obtusely and crenulately 3 -toothed; the upper straight and compressed, with the apex incurved. Style mostly hooked at the tip.-Branching annuals with alternate narrow leaves either entire or 3-5-parted; the floral ones not brightly colored. Flowers one to each bract, dull-colored, yellowish or purplish; the corolla not much exceeding the calyx.

§1. Adenostegra, Gr.-Calyx 2-leaved; flowers short pediceled or nearly sessile, subtended by 2 to 4 bractlets; floral leaves and bracts tipped with a gland.

1. C. filifolius, Nutt. A foot or two high; leaves filiform; the lower entire, the 
upper 3-5-parted, the floral with cuneate base and ciliate margins; corolla purplish, 6 to 9 lines long.

2. C. pilosus, Gr. Larger, soft-villous and hoary; the floral leaves 3-toothed at the tip; corolla yellowish with some purple, less than an inch long.

\$2. Hemistegra, Gr.-Calyx 1-leaved; flowers without bractlets, each sessile in the axil of a claspiny bract; no glands at the tips of tice leures.

3. C. maritimus, Nuts. Leaves smooth, somewhat fleshy, all entire; flowers in a eapitate spike; corolla dull-purplish; pairs of filaments very unequal. - In salt marshes.

4. C. mollis, Gr. Stamens only 2, with smooth filaments; the upper leaves tootied or pinnatifid.-Salt marshes.

\section{PEDICULARIS, Tourn.}

Calyx 2-5-toothed, irregular. Corolla strongly bilabiate; the galea arched and laterally compressed; the lip 2-crested above, 3-lobed. Stamens 4, inclosed in the galea; anthers transverse, equally 2-celled.

1. P. densifora, Denth. Nearly smooth, stout, becoming a foot or more high; leaves broad-lanceolate in outline, twice-pinnatifid or pinnately parted, and the divisions irregularly and sharply incised or toothed; the upper bracts of the dense elongated spike or raceme simpler; calyx-teeth, 5; corolla red or scarlet.

\section{OrDER 44. OROBANCHACEFF.}

Root-parasitic herbs, destitute of leaves and green color. Distinguished from Scrophulariacece by the 1-celled ovary.

\section{APEYLLON, Mitch.}

Calyx 5-cleft, or 5-parted, regular or nearly so. Corolla tubular and curved, almost refular, or bilabiate. Stamens included; cells of the anthers deeply separated from below upward, mucronate at base. Stigma peltate or bilamellar. - Low pale or brownish herbs; the flowers yellowish or purplish.

* Scapes or peduncles naked; corolla with an almost regular 5-lobed border.

1. A. uniflorum, Gr. Coralla about an inch long, bluish purple, violet-scented.

2. A. fasciculatum, Gr. Scaly stem rising out of the ground 2 or 3 inches, bearing many peduncles; lobes of the calyx not longer than the tube; flowers dull yellow or purplish.

* Stems rising above the ground; flowers bracteate; corolla plainly bilabiate.

3. A. comosum, Gr. Low, branching at or near the surface of the ground; flowers 
on slender pedicles in a corymb or short raceme; corolla rose-purple or purple, an inch or more long, or twice the length of the deeply parted calyx; anthers woolly.

4. A. Californicum, Gr. Flowers crowded in an oblong thyrsus or raceme; calyx lobes nearly equaling the tube of the yellowish or purplish corolla; anthers smooth or nearly so.

5. A. tuberosum, G. Flowers small, sessile in a compact eluster; yellowish.

Boschniakia strobilacea, Gr., if found may bo known by its resemblance to a spruce cone, 3 or 4 inches long, the flowers striped with white and brownish red; scale-like bracts brown.

\section{ORDER 45. IABIATZF.}

Chiefly aromatic herbs with square stems, opposite simple leaves, and no stipules, bilabiate corolla, didynamous or diandrous stamens, and a 4-lobed ovary with a singlo style, forming seed-like nutlets in the bottom of the persistent calyx. - Flowers perfect. axillary. Calyx 3-5-toothed or cleft, or bilabiate. Stamens on the tubes of the corolla. Style, 2-cleft at the apex; often unequally so, or one of the lobes obsolete; stigmas minute.

Tribe 1. SATUREIEZZ. Stamens erect or ascending; the posterior pair shorter or wanting; anthers 2-celled, and the short lobes never far separated, sometimes partly confluent but not blended. Upper lip of the corolla never hooded; all the lobes flat or nearly so.

* The small corolla about equally 4-lobed; tube naked within.

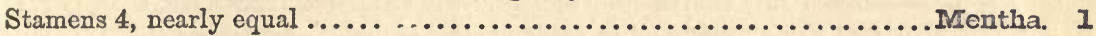
Stamens 2, with anthers; posterior pair sterile or wanting ............ Lycopus. 2

* Corolla bilabiate; no hairy ring within the base of the tube.

+ Calyx about equally 5-toothed and 13-nerved; style beardless.

Flowers glomerate-capitate. Stamens 4, straight.

Stamens distant and divergent........................ Pycnanthemum. 3

Stamens exserted ..................................Monardella. \&

Flowers solitary or clustered in the axils.

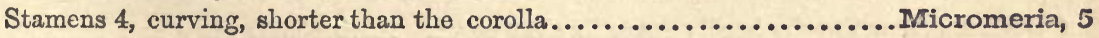

++ Calyx unequally and deeply 5-cleft, mostly 15-nerved; style bearded above.

Stamens 4, sometimes the upper pair sterile....................Pogogyne. $G$

* * Corolla not manifestly bilabiate; a hairy ring at the base of the tube within.

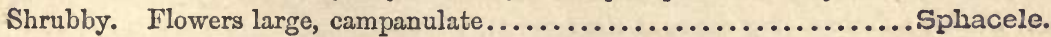

Tribe 2. Monardeas. Stamens only 2, fertile, the upper pair rudimentary or want. ing; anthers apparently or really of a single linear-oblong cell, or of 2 cells widely separated upon the ends of a filament-like connective. 
Connective longer than the filament itself, which it strides, a narrow anthercell at its upper end, a smaller one or a long process at the lower....... Salvia. 8 Connective much shorter than the slender filament and continuous or barely articulated with its apex, or apparently none; anther 1-celled, no rudiment of the second cell below........................ Audibertia. 9

Tribe 3. Stacrixdes. Stamens 4, with anthers, ascending and parallel under the coneave or galeate upper lip of the corolla. Calyx 5-10-nerved. Herbage less aromatic than the preceding tribes.

Calyx with a projection on the upper side, casque-shaped .......... Scutellaria. 10 Calyx bilabiate. Filaments 2 -forked, one fork bearing the anther.......Brunella. 11 Calyx 5-10-nerved, nearly equally 5-toothed............................. 12

Tribe 4. AJUGordEA. Stamens parallel, and protruding from the cleft on the upper side of the corolla; the anterior longer.

Corolla with 5 similar oblong lobes..................... Trichostema.

\section{MENTHA, L. MrNT.}

Calyx about equally 5-toothed. Corolla with a short included tube, and a campanulate border; the upper lobe broadest, entire or emarginate. Odorous herbs, with very small flowers in dense clusters forming an apparent whorl in the axils or spikate at the tops of the branches.

1. M. Canadensis, L. Leaves from oblong-ovate to almost lanceolate, sharply serrate, acute, short-petioled; flowers all in axillary clusters, whitish or purplish.

\section{ITCOPUS, 'lourn. Water Horehound.}

Chiefly distinguished from IMentha by the stamens. Flowers white, in false whorls.

1. L. lucidus, Turcz., var. Americanus, Gr. The subterranean runners producing tubers; leaves lanceolate, 2 to 4 inches long, coarsely serrate, sessile or nearly so.

\section{PYCNAINTHEMUM, Michx.}

Corolla short, with tube hardly exceeding the calyx. Anther-cells close and parallel. Permnial erect herbs with small flowers.

1. P. Californicum, Torr. About 2 feet high, corymbosely branched, sweet-odorous, whitened with soft pubescence, or in age smoothish: leaves from ovate to ovate-lanceolate, closely sessile by a slightly cordate or roundish base, sparingly denticulate or entire; heads of flowers very dense at the summit, white-villous; flowers whitish.

\section{MONARDILIA, Benth.}

Markel by the flowers compacted in terminal heads involucrate with bracts, flesh-color or purple. 
* Perennial, in tufts from a procumbent and almost woody base.

1. M. villosa, Benth. Soft-pubescent or villous a foot or two high; leaves ovate, often with a few obtuse teeth, being 6 to 10 lines long, petioled. Sometimes nearly sinooth.

\section{* * Annual; leaves entire or undulate.}

2. M. undulata, Benth. A span to a foot or more high; leaves from oblong spatulate to nearly linear with a narrowed base, obtuse, undulate-margined, about an inch long; bracts and ealyx villous; corolla rose-color. Has the odor of Peppermint.

3. M. Breweri, Gr. A span or more high; leaves oblong or ovate, pinnately veined, the larger an inch long; bracts broadly ovate, cuspidate, whitish-scarious, the outer pinnately and the inner nervosely 7-9-ribbed; corolla rose-purple.

4. M. Douglasii, Benth. Loosely branched; leaves lanceolate, an inch long, tapering into the petiole; the silvery white or purple-tinged bracts mostly transparent, with a strong marginal vein connected with the midrib by pinnate veins.-Strong-scented; corolla deep rose-color.

\section{MICROMIERIA, Benth.}

Calyx not gibbous. Corolla short; upper lip erect, flattish, entire or cmarginate; lower spreading, 3-parted.-Low plants, sweet-odorous, with small axillary flowers.

1. M. Douglasii, Benth. Yerba Buena. Perennial herb, with long slender creeping and trailing stems; leaves round-ovate, thin, sparingly toothed, short petioled, an inch long or less; flowers mostly solitary on a long filiform 2-bracteolate peduncle; corolla purplish or white, 4 lines long.

2. M. purpurea, Gr. Erect, much branched; leaves lanceolate, acuminate, sparsely serrate; flowers in umbel-like clusters; corolla purple-blue, 2 lines long.

\section{POGOGYINE, Benth.}

Calyx cleft to below the middle; the 2 lower teeth longer; corolla straight, tubularfunnelform, with short lips; the erect and entire upper lip and the three lobes of the spreading lower one oval and somewhat alike. Stamens with the upper shorter pair sometimes sterile; the anther cells parallel and pointless. Style somewhat exserted, bearded above.-Low annuals, sweet-aromatic; with oblong or oblanceolated leaves narrowed into a petiole; flowers mostly crowded and interrupted spicate; bracts and calyx hirsute-ciliate; the corolla blue or purplish.

- Stamens all four with anthers; style conspicuously bearded above, and its subulate lobes almost equal; corolla 6 to 9 lines lonq; flowers densely crowded into an oblong cylindrical spike, which is conspicuously white-lirsute with the long, stiff, ciliate hairs of the calyx.

1. P. Douglasii, Benth. Tather stout, a span to a foot high; leaves veiny. some- 
times sparingly toothed; bracts linear, acute; lower lobes of the calyx much longer than the others.

2. P. parvifora, Benth. Smaller; bracts mostly obtuse; corolla 5 or 6 lines long.

* * Upper stamens sterile; style sparingly hairy, its lobes very unequal; flowers barely 2 lines long.

3. P. serpglloides, Gr. Stems 3 to 6 inches high; leaves obovate-oval or spatulate, 2 or 3 lines long; lower flowers remote and often solitary; the upper usually interruptedly spicate.

\section{SPHACELE, Benth.}

Calyx thin, membranaceous and reticulated. Corolla with 5 broad, rather erect lobes, the lower one longest. Anther cells diverging. Somewhat shrubby, veiny-leaved.

S. calycina, Benth. Villous-pubeseent or tomentose, leafy, 2 to $5 \mathrm{ft}$. high; leaves 2 to 4 inches long, ovate or oblong crenate or serrate, or almost entire; the floral, ovatelanceolate, sessile; flowers an inch long, mostly solitary in the upper axils, purplish or lead-color.

\section{SALVIA, L. SAGE.}

Calyx bilabiate. Corolla deeply 2-lipped, the upper lip erect, straight or falcate, 2-lobed, the lower spreading or drooping, its middle lobe sometimes notehed or obcordate. In our species the upper lip of the calyx is longer than the lower, 3-2-toothed; the lower 2-parted; the teeth spinulose; corolla ringent.

1. S. carduacea, Benth. White-woolly with cobwebby hairs; stcms nearly naked, surrounded at the base with thistle-like leaves; head-like false whorls 1 to 4 , an iuch or more in diameter, about equaling the involucre of spiny-toothed bracts; corolla 10 to 12 lines long, blue or purple.

2. S. Columbaria, Benth. (CuIA.) Soft pubeseent; flower whorls 1 or 2; involucrate bracts, sometimes purplish; corolla 3 or 4 lines long, blue; leaves not spinescent.

\section{AUDIBERTIA, Benth.}

Sufficiently distinguished from Salvia in the synopsis.-Mostly hoary perennials, herbaceous or shrubby; with rugose-veiny, crenulate, sage-like leaves, and densely capitateglomerate flowers.

1. A. grandiflora, Benth. Stems 1 to 3 feet high from a somewhat woody base; lower leaves 3 to 8 inches long; floral ones broadly ovate and membranaceous; corolla an inch and a half long; purple-crimson; stamens much exserted.

2. A. humilis, Benth. A span high, cespitose; leaves mainly radical; spike of 3 or 4 small, sessile, head-like clusters; corolla half an inch long or less, bluish purple.

3. A. stachyoides, Benth. Shrubby, 3 to $S$ feet high; style and stamens littlo exserted; corolla about as the last. 


\section{SCUTELIARIA, L. SKULLCAP.}

Calyx, with two entire lips and a gibbous projection on the back, closed after flowering. Corolla, with an elongated and curved ascending tube, a dilated throat, an crect arched or galeate upper lip, with which the lateral lobes appear to be connected; the anterior lobe appearing to form the whole lower lip.-Herbs, not aromatic; with single axillary, rather conspicuous flowers.

1. S. angustifolia, Pursh. A span to a foot high; leaves about an inch long; the radical ones often roundish or even cordate; corolla blue or violet, an inch long, with a slender tube; lower lobe villous inside.-Ours is mainly

Var. canescens, Gr. A form with soft, hoary pubescence, and the tube of the corolla bent so as to throw the upper part backward.

2. S. Californica, Gr. Puberulent; stems 8 to 20 inches high, slender; leaves from lanceolate-oblong to oval-ovate; the lower an inch or more long, often serrate; upper gradually reduced to half an inch or less; lips of the yellowish corolla about equal.

3. S. tuberosa, Benth. Soft, pubescent or villous; stems slender, erect and short, or trailing a foot in length; the filiform subterranean shoots bearing tubers; leaves mostly ovate, coarsely and obtusely few-toothed or entire, 5 to 18 lines long; corolla deep bluo or violet.

\section{BRUINLIA, Tourn. Self-HeAL.}

Calyx-lips closed in fruit. Corolla with ascending tube, open lips, and slightly-con. tracted orifice; upper lip arched and entire; lower 3-lobed, its middle lobe drooping, rounded, concave, dentieulate.-Low perennials, the flowers crowded in a terminal oblong or cylindraceous head or spike.

1. B. vulgaris, L. A span to a foot or more in height; leaves ovate or oblong, slen. der-petioled; corolla violet, purple, or rarely white; calyx purplish.

\section{STACHYS, L.}

Corolla with cylindrical tube not dilated at the throat; the upper lip erect and concave or arched; the lower spreading, its middle lobe larger. Stamens ascending under the upper lip; filaments naked; anthers approximate in pairs, 2-celled.-Herbs, not aromatic, with flowers clustered, capitate, or scattered, often spicate at the end of the branches; flowers sessile or nearly so.

* Corolla white or whitish; the upper lip bearded or woolly on the back; herbage tomentose or soft hairy.

1. S. ajugoides, Benth. A span to a foot high; silky-villous with whitish hairs; leaves oblong, very obtuse, crenately serrate, 1 to 3 inches long, the upper sessile; flowers about 3 in the axils of the distant upper leaves, and loosely leafy-spicate at the sum. mit.-Moist ground. 
2. S. albens, Gr. Soft-tomentose with whitish wool, 3 to $5 \mathrm{ft}$. high; leaves mostly cordate at base, obtuse, crenate, 2 or 3 inches long; flowers several or many in capitate clusters which usually exceed the small floral leaves and form an interrupted spike; corolla white with purple dots on the lower lip.

3. S. pycnantha, Benth. Very hirsute, with long and mostly soft spreading hairs, not white, two feet high or more; flowers in a dense cylindraceous naked spike (an inch or two long), exceeding the small bract-like floral leaves except in the lowest and sometimes rather distant clusters; corolla white or cream-color, with purple on the lower lip. (?)

* * Corolla purple, the upper lip hairy on the back; pubescence somewhat hispid; no tomentum.

4. S. bullata, Benth. Stem retrorsely hispid, especially on the angles, 1 to $3 \mathrm{ft}$. high; leaves somewhat rugose, nearly all petioled, 1 to 2 inches long; flowers usually 6 in the false whorls, these rather distant, forming a narrow interrupted spike; lower lip of the corolla fully as long as the tube, 4 or 5 lines long, the upper half as long. - Variable.

* * Tube of the rose-red corclla twice as long as the calyx, 6 to 9 lines long.

5. S. Chamissonis, Benth. Stem 2 to $5 \mathrm{ft}$. high, stout, mostly rough-hispid, with retrorse rigid bristles; leaves 2 to 5 inches long; lips of the corolla pubescent outside.Wet ground.

\section{TRICHOSTEMA, L. BLUE-CURLS.}

Calyx campanulate and almost equally 5-cleft. Corolla with short or slender tube and an almost equally 5-parted limb. Stamens with long capillary curved filaments, sometimes cohering at the base.-Strong scented herbs; with entire leaves, and blue or purple corolla and stamens. In ours the flowers are in cymose axillary clusters, somewhat raceme-like in age; the corolla about 5 lines long, and the stamens twice as long or more.

1. T. laxum, Gr. Minutely soft pubescent, about a foot high, simple or loosely branched from the base; leaves rather distant, lanceolate or oblong-lanceolate, tapering into a petiole at the base; flower clusters distinctly peduncled, usually forked and in age equaling the leaves; corolla almost smooth.

2. T. lanceolatum, Benth. Leafy; leaves much longer than the internodes, lanceolate or ovate-lanceolate, sessile by a broad base, 3-5-nerved, an inch or less long; flower elusters nearly sessile, short, one-sided; corolla somewhat pubescent.-Its odor sicken. ing, tarry.

\section{ORDER 46. VERBENACERF.}

Herbs or shrubs differing from Labiatce mainly in the ovary and fruit, which is undiviled and 2-4-celled, at maturity either dry and splitting into as many 1-sceded nutlets, or drupaccous, containing as many little stones. 


\section{VERBENA, L.}

Calyx 5-toothed, one tooth often shorter. Corolla salver-form, the limb unequally 5-cleft. Stamens included, the upper pair sometimes sterile. Stigma unequally lobed. Ovary 4.celled. - Herbs with small flowers, ours about 2 lines in diameter.

1. V. officinalis, L. Some of the lower leaves pinnatifid; spikes mostly solitary, filiform; corolla purple or lilac, 2 or more lines in diameter.

2. V. hastata, L. Stouter and taller, 3 to $6 \mathrm{ft}$. high; leaves serrate or incised, the lower hastate-3-lobed; spikes panicled, densely flowered; corolla blue, 2 lines in diameter.

3. V. prostrata, R. Br. Soft hirsute, diffuse, a foot high; villous spikes long; corolla violet or blue.

\section{ORDER 47. PLANTAGINACE巴E.}

Stemless herbs with flowers in spikes, the 4-cleft regular corolla dry and scarious.

\section{Plantago, L. Plantain.}

Flowers in spikes or heads, bracteate. Calyx of 4 persistent sepals free from the ovary. Stamens 2 or 4 on the corolla alternate with its lobes, anthers versatile. Style filiform, bearded above. - Stemless herbs with nerved or ribbed radical leaves and naked scapes of small greenish flowers.

\section{* Flowers with 4 stamens.}

1. P. major, L. Mostly smooth; leaves ovate or broadly oblong, abruptly contracted into a channeled petiole, 5-7-ribbed; spike long and slender; capsule 7-16-seeder.

2. P. hirtella, HBK. Leaves smooth, rather fleshy, oblanceolate to obovate, 3-7. ribbed, tapering into a narrow base or wing-margined petiole; scape 1 to $3 \mathrm{ft}$. high; flowers large.

3. P. lanceolata, L. Mostly hairy; leaves lanceolate, 3-5-ribbed; scape deeply grooved.

4. P. maritima, L. Leaves linear, fleshy; scapes usually short.

5. P. Patagonica, Jacq. Leaves linear to filiform, thin, usually silky-woolly.-Dry ground.

* * Flowers with 2 stamens.

6. P. Bigelovi1 Fr. Leaves linear; small. -Salt marshes. 


\section{DIVISION 3. APETALAE.}

\section{ORDER 48. ARISTOLOCHIACEZE.}

Twining shrubs or low herbs with perfect flowers, the conspicuous lurid calyx valvate in the bud and coherent with the 6-celled ovary, which forms a many-seeded 6-celled, pod or berry in fruit. Stamens 6-12, more or less united with the style; anthers adnate, extrorse. Leaves petioled, mostly heart-shaped and entire. Gray's Manual.

\section{ARISTOLOCHIA, Tourn.}

Calyx tubular, inflated above the ovary. Stamens 6 , the sessile anthers adnate to the short stigma.

1. A. Californica, Gr. (Pipe-Vine.) A twining shrub with large cordate leaves, flowers curved like a Dutch pipe, greenish, marked with brown or purple.

\section{ASARUM, Tourn.}

Calyx regular, 3-cleft or parted. Stamens 12, with more or less distinct filaments; their tips usually continued beyond the anther into a point.- Stemless herbs with ereeping rootstocks, bearing 2 or 3 scales, then one or two leaves, and terminated by a short peduncled-flower elose to the ground.

1. A. caudatum, Lindl. (Wild Ginger.) The smooth broadly cordate leaves usually mottled with white; calyx bell-shaped, the acuminate lobes spreading, brownish purple. Common in forests; the flowers likely to be hidden under leaves.

\section{ORDER 49. NYCTAGINACE正.}

Herbs with mostly opposite and entire leaves, stems swollen at the joints, the tubular calyx eorolla-like, its persistent base contracted, inclosing the 1-celled 1-seeded ovary, and becoming a sort of indehiscent pod.

\section{ABRONIA, Juss.}

Calyx salverform, with obcordate lobes. Stamens 5, included, adnate to the tube. Style included; stigma, capitate or clavate. Fruit 5-winged. Embryo by abortion monocotyledonous, enfolding mealy albumen. Low herbs, with the opposite thick petioled leaves unequal, and the flowers in involucrate heads. Common on sandy sea beaches. $A$ viscid exudation causes sand to stick to every part of the plants.

1. A. latifolia, Esch. (Yellow Sand-Verbena.) Root perennial; stems procumbent; leaves very thick, sub-cordate to reniform, on thick petioles; flowers orange-yel. low, fragrant. 
2. A. umbellata, Lamb. (Pink Sand-Verbena.) Annual; stems decumbent, leaves oblong or ovate, attenuate at base into slender petioles; flowers pink.

3. A. maritima, Nutt. (Red Sand-Verbena.) Stouter than the last; leaves broader with shorter petioles; involucral bracts ovate; flowers bright red. From Santa Barbara southward.

4. A. fragrans, Nutt, of the Columbia River, has white flowers.

Five other species belonging to this western genus are found east of the Sierra Nevada.

\section{ORDER 50. POLYGONACEF.}

Herbs, with alternate entire leaves, and stipules in the form of sheaths, or obsolete, above the swollen joints of the stem; the flowers mostly perfect, with a more or less persistent calyx, a l-celled ovary, bearing 2 or 4 styles or stigmas, and a single seed. Stamens 4-12 inserted on the base of the 3-6-cleft calyx.

\section{POLYGONUIM, L.}

Calyx 5 parted; the divisions petal-like, persistent in fruit, and surrounding the usually 3 -angled akene. Stamens 3 to 8 . Styles or stigmas 2 or 3 . Herbs with small flowers on jointed pedicels.

Knot-weed or Yard-grass and Smart-weed belong to this genus. About 20 species are found in California, of which 2 or 3 are probably introduced weeds.

\section{RUMEX, L.}

Calyx of 6 sepals; the three outer herbaceous, spreading in fruit; the three inner larger somewhat petaloid, covering the akene in fruit (then called valves), and of ten bearing grainlike appendages on the outside. Stamens 6 . Styles 3 ; stigmas tufted. Introduced weeds with small greenish flowers crowded and whorled in panicled racemes.

The Docks and Sheep-sorrel are examples of this genus. Of the dozen species on this coast, half are introduced weeds.

\section{ERIOGONUM, Michx.}

Flowers borne in a many-to-few-flowered calyx-like involucre of united bracts; the pedicels exserted, jointed to the flower, with bractlets at the base. Calyx corolla-tike; 6-parted or deeply 6-cleft. Stamens 9. Akene triangular.-Herbaceous or somewnat woody plants, usually with a woolly or scurfy pubescence; the entire leaves without stipules and mostly radical; juice frequently acid. Over 80 species grow west of the Mississippi, of which 50 are Californian, mostly Alpine.

Chorizanthe is a similar genus, in which tho involucres are 1-flowered and rigid.

Orders Amarantacea and Chenopodiacea \&re represented by homely introduced ana native weeds. Many of the latter order belong to the genus Chenopodium, viz.. Goosefoot, Lamb's-quarters, Pigweed, Jerusalem 
Oak, Wormseed, etc. Salicornia (Glasswort) grows in salt marshes, and may be known by its leshy leaf. less jointed stems, wilh opposite branches. The garden Beet belongs to this order.

\section{ORDER 51. PIPERACEZF.}

Herbs with jointed stems, alternate entire leaves and perfect flowers in spikes, en. tirely destitute of floral envelopes.

\section{ANEMOPSIS, Hook.}

Flowers in a simple conical spadix, which is surrounded by a 5-8-leaved persistent colored involucre, each flower subtended by a free colored bract. Stamens 6 to 8 , free, growing upon the immersed ovary.

1. A. Californica, Hook. Stem simple, erect, 3 to 15 inches high, with a single broad clasping leaf in the middle, and an axillary branchlet reduced to 1 or more petioled. leaves; radical leaves oblong-oval, cordate at base, 2 to 6 inches long; involucre 1 to $1 \frac{1}{2}$ inches broad, white, becoming brown. Used medicinally by the Mexicans, who call it Yerba Mansa.

\section{APETALOUS TREES.}

The Order Betulaceæ (BIrcir FAmily) is represented in California by two Birches, which scarcely attain to the dignity of trees, and are confined to the high Sierras, and four Alders, two of which grow in the central part of the State, viz.:

Alnus rubra, Bong. (Red Alder), and the more common

Alnus rhombifolia, Nutt (White Alder), which may be distinguished by its thinper leaves, not rusty beneath, and more slender branches not so distinctly dotted with white.

Myrica Californica, Cham. (Bayberry), representing the Order Myricacere grows in moist places, and may be known by its thick oblanceolate serrate evergreen leaves and dense clusters of small fruit, whitened by a coat of wax.

Umbellularia Californica, Nutt (Order Lauraceæ), is the well-known Laurel.

Platanus racemosa, Nutt, is the California Sycamore.

The Order Salicaceæ is represented by 4 or 5 Willows; large enough to be called trees, and 3 Poplars, viz.:

Populus tremuloides, Michx. (Quaking Asp), a small tree, with whitish bark and round ovate leaves. In the high Sierra. The only Californian tree, except one or two willows, found east of the Rocky Mountains.

P. trichacarpa, Torr. \& Gr. (Cottonwood.) Petioles round; young bark brownish.

P. Fremonti, Wat. (Fremont's Cottonwood.) Petioles flattened; young bark yellowish.

The Walnut Family is represented by Juglans Californica, the California Black Walnut.

Ten kinds of Oak Trees, and several shrubs of the same genus, with the chestnut-like Chinquapin, represent the Order Cupuliferæ. The following, inhabiting the foot-hills and valleys. may be distinguished: 
- Deciduous trees; acorns maturing the first season.

+ Bark whitish gray. - White Oaks.

Quercus lobata, Nee. Branches slender, often drooping; acorns tapering, in a deep rough cup. The most common valley oak.

Q. Garryana, Dougl. Branches coarser; bark thinner; acorns obtuse, in a shallow cup; winter buds large.

Q. Douglasii, Hook. \& Arn. (Mountain White Oak or Blue Oak.) Leaves smaller, less deeply lobed or entire, bluish green; acorn tapering, about an inch long.

++ Bark dark colored, rough; large leaves sharply labed.

Q. Kelloggii, Newberry. (Kellogg's Black Oak.) Acorns large, obtuse, very hairy inside. Common in the Coast Ranges and foot-hills of the Sierra Nevada.

* * Evergreen trees; acorns maturing the second season.-Live Oaks.

Q. chrysolepis, Liebm. Bark ash-gray; acorns obtuse; cup tawny or yellow.

Q. Wislizenii, A. DC. Bark black; acorns slender, tapering.

Q. densiflora, Hook. \& Arn. (Chestnut Oak.) Differing from all other oaks in having erect aments. Acorns large, obtuse, in thick cups, which are covered with slender, rigid, recurved scales.

* * * Evergreen trees; acorns maturing the first season.

Q. agrifolia, Nee. Chiefly distinguished from $\mathbf{Q}$. Wislizenii by its annual acorns.

Order Thymeleaceæ is represented by Dirca occidentalis or Leatherwood, a branching shrub, 3 or 4 feet high, with flowers in axillary clusters of 3 or 4 . 


\section{Class II.-ENDOGENS OR MONOCOTYLEDONS.}

Stems consisting of woody tissue and cellular tissue (pith) intermixed. Embryo monocotyledonous.

\section{ORDER 52. ALISMACEF.}

Marsh herbs, with leaves all radical, scape-like flowering stems, and (in our species) perfect flowers. Sepals and petals each three and distinct. Ovaries 3 to many; distinct, or, at least, separating at maturity, forming 1-2-seeded pods. Stamens from 6 to many; anthers extrorse, 2-celled. (See Addenda.)

* Calyx and corolla colored alike, deciduous. Carpels 6, united. Leaves rush-like.

\section{TrIGLOCHIN, L. Arrow-Grass.}

Flowers small, sessile, on a naked scape. Sepals and petals ovate, greenish-white. Stamens 6, filaments short. Stigmas sessile.

1. T. maritimum, L. Fruit ovoid-oblong, grooved, separating into 6 linear carpels; scape surpassing the leaves, angled-In salt marshes.

* Calyx green and persistent. Corolla white, deciduous. Carpels many, distinct (Alisma), or 8 to 10 cohering (Damsonium). Leaves long-petioled, with broad llade.

\section{Alisma, L. Water-Plantain.}

Flowers small, verticillate, in a panicle on a scape. The numerous ovaries becoming flattened akenes, arranged in a somewhat three-sided whorl.

1. A. plantago, L., var. Americanum, Gr. Leaves long-petioled ovate or oblong, often cordate at the base, 3-9-nerved; scapes 1 to 4 feet high; the white or pinkish petals entire, broadly-elliptical; carpels 15 to 20 , obliquely obovate, channeled around the outer end.

\section{DAMSONIUM.}

Distinguished from Alisma chiefly by the 8 to 10 long-beaked carpels cohering by their inner edges in a stellate whorl.

1. D. Californicum, Torr. Leaves on long petioles, oblong or lanceolate, with obtuse or cordate base, 2 or 3 inches long; whorls distant, 6-9-flowered, on scapes 12 to 18 inches high; flowers twice as large as those of Alisma plantago; the petals incisely cut at the apex; akenes 4 or 5 lines long.

\section{ORDER 53. ORCHIDACEF.}

Herbs with irregular 6-merous perianth adnatè to the l-celled ovary; the ovules innumerable on 3 parietal placentse, becoming fine sawdust-like seeds. One petal, called the lip, is unlike the other two. Stamens consolidated with the style forming the Column. 


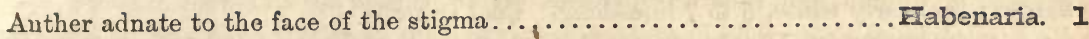
Anther arlnate to the back of the stigma.

Lip free from the column......................... Epipactis. 2

Lip adherent to the base of the column................. Spiranthes. 3 Anther like a lid over the stigma. (See ADDENDA.)

Lip with a spur adherent to the ovary................. Corallorhiza. 4 * * Anthers two, one on each side of the column.

Lip a conspicuous inflated $\operatorname{sac} \ldots \ldots \ldots \ldots \ldots \ldots \ldots \ldots \ldots$ Cypripedium. 5

1. habenARIA, Willd., R. Br. Reis Orchis.

Flowers ringent; the sepals and petals similar; lip spurlike; ovary twisted. Swamps.

1. II. elegans, Lindl. The greenish flowers in a dense spike; spur filiform.

2. H. leucostachys. Stems 1 to 3 feet high; spikes 4 to 18 inches long; flowers largo, greenish, the spur longer than the entire lip, 6 to 9 lines long.

2. EPIPACTIS, Hall.

Petals and sepals similar, spreading, nearly equal. Lip oblong, the upper portion concave and fleshy, the lower petaloid, undivided. Stigma square, projecting downward.

1. ․ gigantea, Dougl. Leaves plicate; flowers brownish or purplish, pediceled in a spicate raceme, pubescent. Borders of streams.

\section{SPIRANTHES, Richard. Ladies' Tresses.}

Flower oblique on the ovary, the 3 upper segments erect, and more cr less cohering, the bases of the lip covered by the remaining two segments, and bearing a pair of callosities. Flowers in a twisted spike, small, green or greenish white.

S. Romanzofiana, Cham. Smooth, 4 to 18 inches high, leafy; dense spike 3-ranked, bracteate; perianth, white, 4 lines long; petals and sepals incurved; callosities small and smooth.

S. porrifolia, Lindl. Similar; flowers smaller, callosities larger.

4. CORALlorhiza, Haller. Coral-root.

Perianth-segments nearly equal, the lower one (lip) bearing at the base a pair of projecting ridges. Brownish or yellowish, leafless herbs with sheathing bracts; flowers in spiked racemes.

1. C. Bigelovii, Wat. Plant purplish, simple stems 12 to 18 inches high, bearing 20 or 30 flowers in a crowded spike, on very short pedicels; perianth-segments 4 to 6 lines long, marked with 3 dark stripes; capsules reflexed.

\section{CYPRIPEDIUM, L. LADY'S SLIPPER.}

Sepals spreading, distinct, or two lower united. Petals resembling the sepals. Lip a large inflated sac. Style bearing on each side a short stamen, the stigma covered by a triangular petal-like sterile stamen, which bends clown over it. 
1. C. Californicum, Gr. Stems 1 to $3 \mathrm{ft}$. high, bearing several to twenty (ir more flowers; lip nearly white, 5 to 7 lines long. Cool swamps.

2. C. montanum, Dougl. Stems shorter; flowers rarely more than 2 or 3 ; lip much larger, white marked with yellow and purple. Forests.

\section{ORDER 54. IRIDACEFA.}

Herbs with 2-ranked leaves, the flower buds inclosed by bracts. Perianth adherent to the ovary, segments in two, often tinequal, sets. Stamens 3, anthers extrorse. Ovary 3-celled, style 1, stigmas 3 , often petaloid.

\section{IRIS, L. FLAG.}

Outer segments of the perianth spreading or reflexed and larger than the erect or incurving petals. Stamens distinct, covered by the petaloid stigmas. Plants springing from thickened rootstocks, with sword-shaped leaves and showy flowers.

1. I. longipetala has large, light blue flowers, with rather slender petals. Grows in masses on moist hill siles.

2. I. Douglasiana has (usually) light yellow flowers, with the tube of the perianth prolonged considerably beyond the ovary. - Open woods.

3. I. macrosiphon. Torr. Stems very short from a slender rootstock; leaves slender; flowers bright purple; perianth tube very long and slender; ovary tapering to a short peduncle.

\section{SISYRINCAIUM, L.}

Flowers small; the segments of the perianth flat, equal. Stamens united. Stigma 3. cleft. Grass-like plants, with winged scapes.

1. S. bellum, Wat. Flowers blue; ovary globular. Hillsides.

2. S. Californicum, Ait. f. Flowers yellow, larger; ovary nearly ovoid. Swamps.

\section{Order 55. LILIACRE.}

Herbs, or rarely woody plants, with regular and symmetrical flowers; the perianth free from the chiefly 3-celled ovary, with the divisions all petaloid (except in I'rillium and Calochortus), the stamens opposite the divisions of the perianth (in some Brodicea, 3 alternating with 3 staminodia), with 2-celled anthers; fruit a few-many-seeded pod or berry; the seeds with copious albumen.

SEries I. Floral bracts present and more or less scarious. Perianth persistent; segments 1-several-nerved. Stanjens perigynous; anthers introrse. Style undivided, persistent (except in Chlorogalum). Fruit a loculicidal capsule with black seeds (except in Smilacina and Maianthemum). See Leucocrinum at the end.

§ 1. Inflorescence umbellate, upon a nakel scape arising from a corm or bulb.

" Bracts 2 (sometimes 4), broad and spathaceous; capsule lobed........... Alium. I 
* * Bracts several, not spathaceous, distinct; capsule not lobed.

- Perianth parted to the base or nearly so; segments spreading, closely 2-3-nerved; stamens in one row at the base; anthers versatile; capsule obovoid or subglobose, sessile or nearly so.

Flowers greenish-white; pedicels not jointed; leaves several.............Muilla. 2

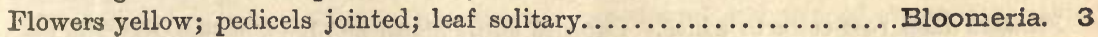

++ Perianth with segments more or less united and the stamens on the throat; pedicels jointed.

Perianth funnel-form, not saccate at the base, blue-purple, white or yellow. . Brodiæa. 4 Perianth tube 6 -saccate at base, deep scarlet.................... Brevoortia. 5

\section{§ 2. Inflorescence racemose or paniculate.}

Flowers on a scape, blue......................................... 6 Flowers on a leafy stem, white.

Stem from a large densely fibrous-coated bulb.............Chlorogalum. 7

Stem from a creeping rootstock; leaves cordate to lanceolate.

Leaves many, sessile. Flowers 3 -merous.............. Smilacina. 8

Leaves 2 or 3 , mostly petiolate. Flowers 2 -merous.... Maianthemum. 9

Stem stout, with rigid sheathing bracts................... Yucca. 10

SerIes II. Floral bracts none or foliaceous. Perianth deciduous (except in Trillium); segments distinct. Stamens hypogynous or at the very base; anthers more or less extrorse (introrse in Trillium). Styles deciduous (or sessile stigmas persistent). Flowers mostly large and showy. (See ADDEnda.)

§ 1. Stem more or less leafy from a bulb or corm. Fruit capsular.

* Perianth segments similar.

Anthers distinctly versatile; style undivided...................... Iilium. 11 Anthers obscurely versatile; style divided to the middle............. Fritillaria. 12 * * Perianth segments unlike.

Anthers basifixed; stigmas sessile........................................ 13

§ 2. Stem from a rootstock. Perianth segments similar. Fruit a berry. Flowers apparently axillary on leafy branches................. Streptopus. 14

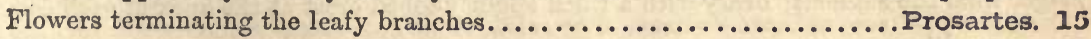

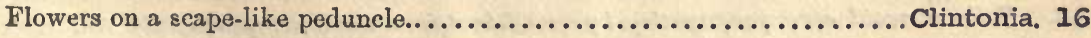

\$ 3. Stem from a thick rootstock. Perianth segments dissimilar. Flowers umbellate subtended by a pair of radical leaves............. Scoliopus, 17 Elowers solitary subtended by a cauline whorl of 3 leaves ............ Trillium. I8

Series III. Perianth persistent; segments distinct. Stamens at the base of the perianth; anthers extrorse, versatile, small, distinctly 2-celled (except in leratrum). Styles distinct. Flowers in simple racemes or panicles. 
Stem from a thick rootstick; leaves broad and sheathing...........Veratrum. 19 Stem from a bulb; leaves narrow......................... Zygadenus. 20 Stem covered with rigid bracts; leaves grass-like.............. Xerophyllum. 21

\section{Aluium, L. Onion. LeeK. Garlic.}

Flowers deep rose-color to white. Capsule sub-globose or obovoid, inclosing the base of the style between the lobes; the filiform style jointed upon the short axis. Filaments tapering upward from the dilated bases. Leaves one to several. Scape from a coated bulb or corm.

§ 1. Bulbs globose to ovoid, mostly solitary; leaves narrowly linear, 2 to 4, shorter than or equaling the scape.

1. A. attenuifolium, Kellogg. Leaves channeled; slender scape 6 to 15 inches high, leafy below; spathe-valves short and abruptly acute; umbel usually dense; perianth segrments 3 or 4 lines long, oblong lanceolate, nearly white.

2. A. serratum, Wat. Resembling the last; leaves very narrow; spathe-valves narrowly acuminate; the deep rose-colored perianth segments 4 to 6 lines long, broadly ovate-lanceolate and rather rigid.

3. A. bisceptrum, Wat. Bulbs light-colored; leaves often 2 or 3 lines broad; scapes frequently in pairs; flowers few to many, rose-colored, 3 or 4 lines long, segments oblonglanceolate; the alternate filaments with a broad deltoid base; the thin crests of the ovary conspicuous.

4. A. lacunosum, Wat. Flowers similar to the last, usually few $(5$ to 20$)$ on pedi. cels 3 to 5 lines long; filaments all narrowly deltoid at base; ovary scarcely crested.

§2. Bulbs ovoid; leaves 2 , broadly linear, flat and falcate, thick; scape stoul, much compressed and 2-vvinged, mostly shorter than the leaves; spathe 2-valved; rose-colored flowers.

5. A. falcifolium, Hook \& Arn. Scape 2 or 3 inches high; the spreading segments of the perianth 4 to 6 lines long, nearly twice longer than the stamens and style, minutely glandular-serrate; capsule acute with 3 short narrow central crests.

6. A. Breweri, Wat. Segments of the perianth nearly erect, not serrulate, a third longer than the stamens; ovary with a thick slightly-lobed crest at the apex of each cell.

§3. Bulb an ovoid corm propagating by an offshoot from the lower part of the tall terete scape; capsule not crested.

7. A. unifolium, Kellogg. Scape a foot or two high; flowers bright rose-color, 5 to 7 lines long, on pedicels an inch long or more.

\section{MUILLA, Watson.}

Sufficiently characterized in the synopsis and by the solitary species. 
M. maritima, Wat. Corm small; leaves scabrous, a line wide or less; the slexier scabrous scape 2 to 6 inches high, with 4 to 6 linear bracts; perianth subrotate, the segments 2 or 3 lines long.-In saline localities.

\section{BLOOMERIA, Kellogg.}

Filaments free, surrounded by a somewhat cap-shaped and winged appendage. One species only.

B. aurea, Kellogg. Corm small, leaf 3 to 6 lines broad; scabrous scape 6 to 18 inches high; flowers numerous on slender pedicels, subrotate, the segments 4 to 6 lines long; appendages of the filaments nearly a line long, with a terminal cusp.

\section{BRODImA, Smith.}

Perianth more or less narrowly funnel-form, not contracted at the throat. Stamens 6 in one, or two rows with winged or naked filaments, or 3 and alternate, with as many staminodia. Capsule ovoid to oblong.

Stamens in one row on the throat; anthers basifixed; purplish perianth mostly broadly funnel-form, the tube shorter than the limb. - $\$ 1$. Eubrodicea.

Stamens in two rows (except in B. Bridgesii), with more or less distinctly versatile anthers and naked filaments; capsule stipitate; perianth segments equaling or shorter than the mostly narrow tube. $-\$ 2$. Seubertia.

Stamens in one row, with deltoid or wing dilated filaments and versatile anthers; capsule stipitate; perianth segment twice longer than the turbinate tube.- $\$ 3$. Calliprora.

\section{§1. Eubrodicea.}

- Stamens 3, opposite the inner segments, and alternate with as many staminodia; segments 2 or 3 times as long as the tube.

$$
\text { + Pedicels (usually few) more or less elongated. }
$$

1. B. grandiflora, Smith. Leaves a line broad, subterete; scape 4 to 10 inches high; flowers an inch long; staminodia entire, obtuse, about equaling the linear anthers; fllaments $1 \frac{1}{2}$ lines long or more; capsule oblong, narrowed at base; cells 6-8-seeded; seeds a line long.

Var. major, Benth. Leaves flattened broader; scape stouter, a foot or two high; pedicels more numerous and longer; capsules with usually a broader base; seeds larger.

2. B. minor, Wat. Scape very slender, 3 to 6 inches high; flowers a half to an inch long; staminodia broad and usually emarginate, longer than the oblong anthers; capsule obovoid, acute, 3 lines long; cells 3 -seeded.

3. B. terrestris, Kellogg. Leaves nearly terete; scape very short; pedicels very slender, 3 or 4 inches long; flowers 8 or 10 lines long; staminodia emarginate, yellow, exceeding the oblong sagittate anthers; capsule acute at base, a half inch long; cells 6-8seeded. 
* Flowers subcapilate.

4. B. congesta, Smith. Corm often deep-seated; scape 2 to $4 \mathrm{ft}$. high, smooth; umbel often produced into a short dense raceme; flowers about 9 lines long; staminodia deeply cleft, exceeding the nearly sessile emarginate anthers; capsule ovoid; seeds usually solitary, 2 lines long.

5. B. multiflora, Benth. Corm less deeply reated; scape 1 or $2 \mathrm{ft}$. liigh, somewhat scabrous; umbel not produced; staminodia broad, entire, obtuse, about equaling the anthers; seeds several in each cell.

* * Stamens 6 , those opposite the inner perianth segments with their short filaments conspicuously wing-appendaged; segments little longer than the tube; flowers subcapitate.

6. B. capitata, Benth. Scape usually 1 or $2 \mathrm{ft}$. high; flowers 6 to 10 lines long; outer filaments dilated at the base; inner anthers linear, little shorter than the oblonglanceolate wings; ovoid capsule 3 lines long.

\section{§2. Seubertia.}

* Perianth more or less attenuate at base; umbel open; flowers blue or purplish, rarely white.

7. B. Bridgesii, Wat. Scape a foot high or more; flowers 12 to 15 lines longs the very narrow tube exceeding the segments; filaments deltoid in one row on the throat; anthers linear, 2 lines long; capsule ovoid shorter than the stipe, beaked by the very slender style; seeds 2 or 3 in each cell.

8. B. laxa, Wat. Scape 6 inches to $2 \mathrm{ft}$. high, smooth or scabrous; flowers few to many, 12 to 20 lines long, the very narrow tube equaling or exceeding the segments; filaments very slender, the upper on the throat opposite the inner segments; eapsule oblong, long-stipitate; style rather short; seeds several.

9. B. peduncularis, Wat. Scape 1 or $2 \mathrm{ft}$. high, smooth; flowers 6 to 9 lines long, on very slender pedicels, the segments a little longer than the turbinate tube; lower anthers sessile, the upper on short filaments; stipe 1 or 2 lines long.

B. crocea Wat. and B. gracilis, Wat., with yellow flowers, grow in the northern counties. The latter only 2 to 4 inches high; leaf solitary.

\section{§3. Calliprora.}

10. B. ixioides, Wat. Scape 3 inches to $2 \mathrm{ft}$. high, usually scabrous; flowers yellow, more or less tinged with purple or nearly white (the brown mid-vein often double or triple), 5 to 10 lines long, on pedicels 1 to 4 inches long; filaments winged their whole length, bicuspidate above; capsule ovoid-oblong.

11. B. lactea, Wat. Scape usually 1 or $2 \mathrm{ft}$. high, smooth or scabrous; flowers white, with green mid-veins or sometimes purplish, 4 or 5 lines long on slender pedicels; filaments deltoid, a line long; capsule subglobose.-A stouter form north.

Stropholirion Californicum, Torr., may be distinguished from Brodicea by its rose. 
colored saccate perianth, and lax often twining scape. The short perianth tube contracted at the throat and the nearly sessile ovary separates it from Brevoortia.

\section{BREVOORTIA, Wood.}

Perianth-tube broad, 6-saccate at base, deep scarlet, several times longer than the short erect or reflexed yellowish limb. Stamens 3, alternate with three broad truncate staminodia; anthers basifixed, nearly sessile. Capsule long-stipitate.

1. B. coccinea, Wat. Scape erect, 1 to $3 \mathrm{ft}$. high, with reddish bracts; pedicels 6 to 15 , an inch long or less; flowers 12 to 16 lines long.--Sometimes called Vegetable Fire Cracker.

\section{CAMASSIA, Lindl.}

Perianth-segments narrow, widely spreading, mostly deciduous. Style thread-like, the base persistent. Flowers in a loose raceme.

1. C. esculenta, Lindl. (Wild Hyacinth or Camass). Scape stout, 1 to $2 \mathrm{ft}$. high; leaves flat, 3 to 8 lines broad; pedicels mostly shorter than the dark-blue (rarely white) flowers; the perianth-segments 7 to 15 lines long, a little exceeding the stamens.

The tunicated bulb is an article of food among the Indians.

7. CHLOROGALUM, Kunth.

Flowers white or pinkish, in loose paniculate racemes; bullss with membranous or densely fibrous coats.

C. pomeridianum, Kunth. (Soap Root.) Bulb large, thickly coated with coarse brown fibers; stem and spreading panicle 1 to $3 \mathrm{ft}$. high. Flowers purple-veined, 8 to 10 lines long on spreading pedicels 2 to 9 lines long.

C. angustifolium, Kellogg. Bulb-coat, thin; flowers smaller, greenish-veined.

\section{Simituacina, Desf. False Solomon's Seal.}

Flowers small white, trimerous, with minute scarious bracts, in a racemose panicle or simple raceme on an erect leafy stem. Stamens at the base; filaments subulate; the short anthers versatile. Style short, persistent; stigma 3-lobed.

1. S. amplexicaulis, Nutt. Leaves pubescent, ovate to lanceolate, rarely at all acuminate, mostly clasping at base; the close raceme compound, berries reddish.

2. 5. stellata, Desf. Leaves smooth or pubescent, lanceolate, acutish, closely clasping, usually ascending and folded; raceme simple, few-flowered, about an inch long; perianth-segments 2 or 3 lines long exceeding the pedicels; berry 3 lines broad, blueblack.

3. S. sessilifolia, Nutt. Taller than the last (a foot or two high) leaves acuminate, usually flat and spreading; raceme larger, the pedicels 2 to 7 lines long; berry 3 to 5 lines in diameter, blue-black.

\section{MAIANTHEMUM, Weber.}

Flowers white, in a simple narrow raceme; perianth 4-parted; stamens 4. Leaves 2 or 3, with cordate base. Berry red. Otherwise as Smilacina. 
M. bifolium, DC. Somewhat pubescent; about six inches high; leaves ovate-cor. date with a broad sinus; style long and slender; berry 2 lines in diameter.

\section{YUCCA, L.}

Perianth campanulate, white or whitish; segments ovate-lanceolate, many nerved, Filaments clavate; anthers small. Style stout and persistent (or none); the emarginate stigmas connate into a stigmatic tube.

1. I. Whipplel, Torr. Caudex none or short; leaves rigid, serrulate, smooth, ending in a brown spine; scape 4 to $12 \mathrm{ft}$. high with imbricated sheatling bracts; panicle narrow and spike-like, dense; greenish-white flowers sub-rotate; segments oblong. lanceolate, 1 or 2 inches long; stigma slightly 3 -lobed.

\section{LILIUM, Tourn. LILY.}

Perianth-segments spreading or recurved, with a honey-bearing furrow at the base. Anthers linear, distinctly versatile. Style long; stigma 3-lobed. Capsule not sharply angled; seeds flat. Stem simple, bearing many whorled or scattered sessile leaves and one to many showy flowers.

\section{* Perianth-segments narrowing gradually into a claw.}

1. L. rubescens, Wat. Leaves oblanceolate more or less verticillate; flowers ascending or nearly erect, usually $1 \frac{1}{2}$ or 2 inches long, with revolute segments, pale lilac or nearly white, becoming rose-purple; anthers 2 or 3 lines long.

L. Washingtonianum, Kellogg, of the northern counties, is much larger, the fragrant white flowers 3 or 4 inches long.

* * Perianth-segments oblanceolate, yellow or ornnge, coarsely spotted with brown.

2. I. maritimum, Kellogg. Stem rather low; leaves usually scattered; narrow, often obtuse; flowers solitary or few, horizontal, $1 \frac{1}{4}$ to 2 inches long, deep reddishorange. Style and stamens short, anthers 2 lines long.

3. I. parcalinum, Kellogg (Tiger Lily). Rhizome thick and branching; scales jointed below; leaves flat, smooth, narrowly lanceolate to linear, the middle in whorls of 9 to 15; flowers bright orange red, lighter to yellow in the center, 2 or 3 inches long; sezrnents strongly revolute; anthers 4 or 5 lines long.

L. Parryi, Wat., of San Bernadino Co., has pale yellow flowers.

I. Parvum KellogG, of the Sierra Nevada, has small yellow cr orange flowers on large stems from rhizomatous bulb.

L. Columpianum, Hanson, of the northern Sierra Nevada, resembles L. Pardalinus; but the bulb is small, not rhizomatous.

L. HUMBold TII, closely resembles the last, but has a large bulb, 10 to 20 leaves in a whorl, larger flowers and an obovoid capsule.

\section{FRITILIARIA, L.}

Perianth segments mostly broader than in Lilium and concave; the anthers more obscurely versatile. Nectary a shallow pit. Styles united to the middle in our species. 
Bu!b-scales mostly slrort, very thick; the flowers 18 lines or less in length; frequently mottled.

\section{* Capsule rather obtusely angled; bulb-scales 3 or 4 lines long.}

1. F. recurva, Benth. Bulb-scales numcrous and thiek; leaves linear-lanceolate, mostly in two whorls near the middle of the stem; flowers 1 to 7 , tinged or blotched with light purple or scarlet, 12 to 18 lines long; segments narrowly oblanceolate with recurved tips; stamens shorter, equaling the very slender style. Sierra Nevada.

2. F. liliacea, Lindl. (Green Lily.) Bulb-scales few, very thick; leaves oblanceolate to linear, approximate or whorled near the base; flowers 1 to 5 greenish white (not blotehed), 8 to 12 lines long, segments oblanceolate, spreading; style stout.

3. F. biflora, Lindl. Usually low; bulb-seales few, ovoid, often tipped with a small scarious blade; leaves narrowly lanceolate to oblong-lanceolate, few, scattered or somewhat whorled near the base: flowers 1 to 3 , dark brownish or greenish purple, segments widely spreading; capsule broadly obovoid.

* * Capsule acutely angled or winged; bulb-scales thick, about 6 lines long.

4. F. lanceolata, Pursh. Leaves in 1 to 3 whorls above the middle of the stem; flowers 1 or 2 , brownish purple mottled with greenish yellow; segments narrowly oblanceolate; stamens 6 or 8 lines long.

Var. floribunda, Benth. Flowers 4 to 8 , or rarely fewer, grecnish yellow blotched with purple; segments 4 to 6 lines broad, strongly arched with broad nectarios, acute; lower pedieels an inch long or more.

Var. gracilis, Wat. Flowers smaller than the last, with narrow segments.

5. F. parviflora, Torr. Leaves linear, whorled; flowers small on short recurved pedicels, yellowish, tinged with purple. Sierra Nevada.

F. pluriflo:a, Torr., with styles united to the summit, a tall species with reddish purple flowers, grows in the Sierra Nevada.

\section{CAIOCEORTUS, Pursh.}

Flowers mostly large and showy, broadly campanulate; the outer segments sepaloid, the inner dilated and mostly with pitted and bearded or crested glands. Stigmas sessile, distinct, recurved, persistent. Capsule usually deeply triquetrous. Stem usually branched and lax or flexuous, from a coated corm, sparingly leafy; leaves with transverse veinlets.

Inner perianth-segments strongly arched and broadly pitted, the gland usually with a transverse scale or fringe; flowers or fruit more or less nodding, and stem usually lax. \$1. Eucalychortus.

Flowers open-campanulate with nsually densely hairy glands without scales; outer seg. ments often hairy or glandular within; pedicels stout, erect; stems stouter. $-\$ 2$. Mariposa.

\section{§1. Eucalychortus.}

- Flowers subglobose, nodding; stem usually tall and branching. 
1. C. albus, Dougl. (Snowy Lily-Bell.) Stem 1 to $3 \mathrm{ft}$. high; flowers white with purplish base; petals acutish, an inch long; bearded and ciliate; gland lunate, with four transverse imbricate fringed scales.

2. C. pulchellus, Dougl. (Golden Lily-Bell.) Stem usually a foot high or more; flowers yellow or orange; petals ciliate and bearded with glandular tipped hairs, deeply pitted, the gland covered by the reflexed stiff hairs of its upper margin. Coast Range.

* * Flowers campanulate, erect when open; pedicels becoming recurved; stem mostly low and flowers often subumbellate.

3. C. Benthami, Baker. Resembling the last; stem low and leaves narrow; the yellow flowers nearly erect, petals 6 lines long, mostly obtuse, often deep brown at base. Sierra Nevada.

4. C. Maweanus, Leichtlin. Low, usually branched; bracts an inch long or more; petals white, purplish at base, hairy, 6 to 8 lines long, somewhat pitted, the gland covered by a broad semicircular scale. Coast Range.

5. C. cæruleus, Wat. Low, umbellately 2-5-llowered; pedicels very slender, petals 6 or 7 lines long, hairy, lilac dotted and lined with blue, the gland covercel by a fringed scale; capsule orbicular or nearly so, 6 lines long. Sierra Nevada.

6. C. nudus, Wat. Low; leaf solitary, 3 to 10 lines broad; bracts rarely an inch long; flowers 1 to 6 in an umbel; petals 4 to 10 lines long, white or pale lilac, without hairs, denticulate. Sierra Nevada.

7. C. lilacinus, Kellogg. Stem bulbiferous near the base, with broal leaves and long conspicuous bracts; flowers 4 to 10 , on long pedicels in 1 to 3 umbels; petals pale lilac with purplish claw, 6 to 12 lines long; somewhat hairy below the middle; gland ciliate-margined, scale narrow; capsule elliptical, an inch long. Coast Range.

8. C. uniflorus, Hook \& Arn. Stem very short, bulbiferous, 1-2-flowered; petals lilac with purplish claw, the lower half hairy above the small purple densely hairy gland. Coast lange.

§ 2. Mariposa. Butterfly Lily.

* Flowers yellow or orange, marked with brown or purple.

9. C. Weedii, Wood. Corm fibrous coated; stem leafy, 1-3-flowered; leaves convolute; sepals with a slightly hairy brown spot; petals deep yellow, dotted and often margined with purple, covered with slender hairs and ciliate an inch long or more; gland small, densely hairy. Coast Range.

10. C. luteus, Dougl. Stem bulbiferous near the base, 1-6-flowered; leaves narrow; sepals narrowly lanceolate with a brown spot; petals an inch or two long, yellow to deep orange, lined with brownish purple especially on the middle where it is slightly liairy; claw purplish; gland round or somewhat lunate, densely covered with ascencling hairs. Variable in color and markings, perhaps running into C. venustus. Coast and Sierra Nevada. 
11. C. venustus, Benth. Petals whito or pale lilac, with a more or less conspicuous reddish spot at top, a brownish yellow-bordered center, and a brownish base; gland large, oblong, usually densely hairy. Var. purpuruscens has deep lilac or purplish petals. Coast Range.

\section{STREPTOPUS, Michx.}

The pendulous flowers solitary or in pairs, on thread-like peduncles, which bend around from nearly opposite the leaves so as to appear axillary. Anthers sagittate.

1. S. amplexifolius, D C. (Twisted Stalk.) Leaves very smooth, strongly clasping; flowers greenish white, half an inch long; fruit a slightly 3-lobed reddish berry.

\section{PROSARTES, D. Don.}

Flowers in fascicles or solitary terminating the branches, white or greenish, sub-erect or pendulous; segments acute or acuminate. Anthers on slender filaments, oblong, obtuse, dehiscing laterally. Styles united. Fruit a somewhat fleshy, obtusely-lobed reddish berry. Leaves with reticulated veinlets.

1. P. Hookeri, Torr. More or less rough-pubescent, with short usually spreading hairs; leaves ovate or sometimes oblong, cordate-clasping base, acute or shortly acuminate; perianth usually rather broad at base, spreading segments acute, 5 or 6 lines long, about equaling the stamens; ovary pubescent, stigma entire; fruit obovoid, obtuse. Coast Range.

2. P. trachyandra, Torr. Resembling the last; leaves less deeply cordate and broaler toward the apex; stamens a third shorter than the perianth; ovary smooth; fruit beaked. Sierra Nevada.

P. Menziesii, Don., of the northern coast has ovate leaves and a 3-cleft stigna.

\section{CLINTONIA, Raf.}

Flowers in our species umbellate upon a scape-like peduncle, rose-colored. Ovary 2-celled; stigma slightly 2-lobed. Fruit a deep-blue berry. Leaves radical; large oblanceolate, sheathing, ciliate.

1. C. Andrewsiana, Torr. Scape a foot or two high, usnally with a foliaceous bract and one or more few-flowered lateral fascicles; inflorescence more or less pubescent; fluwers suberect, deep rose-color, the oblanceolate segments gibbous at base, 4 to 7 lines long, exceeding the stamens and style.

C. uniflora, Kunth., has a large solitary white flower on a short scape. Sierra Nevada and Nurth Coast.

\section{SCOLIOPUS, Torr.}

Flowers purplish, on slender flexuose pedicels; outer segments lanceolate, inner narrowly linear. Anthers oblong; filaments short. Style short; stigmas recurved. Fruit triquetrous. Whole plant brown-punctate, smooth.

1. S. Bigelovii, Torr. Leaves oval-elliptic to narrowly oblanceolate, 4 to 15 inches long; pedicels 3 to 12,3 to $S$ inches long. 


\section{Trillium, L. Three-Leaved Nightshade.}

Flowers white to purple; outer segments green, inner petaloid. Anthers adnate introrse. Stigmas linear, sessile. Stem bearing at the top a single whorl of 3 broad netted-veined leaves.

1. 2. sessile, L. var. Californicum, Wat. The sessile leaves broadly rhombicovate, 3 to 6 inches long; flower sessile, petals oblanccolate to rhombic-ovate, 1 to 4 inches long, purple or rose-color or white.

2. ․ ovatum, Pursh. (Wake Robin.) Leaves similar to the last, smaller; flower oin a pedicel, white, turning rose-color.

\section{Veramrum, Tourn. False Helmbore.}

Perianth slightly adherent to ths ovary. Anthers cordate or reniform, peltate after opening. Capsule membranous, 3-beaked. Stems stout and leafy from thick rootstocks.

I. V. Californicum, Durand. Stem several feet high; lower leaves broad-elliptical, upper leaves lanceolate; bracts usually exceeding the pedicels; perianth-segments broadly oblanceolate, whitish with greener base, often denticulate, 3 to 8 lines long; capsule an inch long.-Moist places.

2. V. fimbriatum, Gr. Leaves narrowed at base, 6 to 18 inches long, 2 to 6 inches wide, acute or acuminate; perianth-segments rhombic-ovate 3 to 5 lines long: capsule 4 lines long.-Swamps.

\section{ZYGADENUS, Michx.}

Flowers white or greenish, erect in paniculate or simple racemes. Perianth-segments oblong-lanceolate to ovate, mostly glandular and somewhat narrowed at base.

1. Z. Fremontii, Torr. Stem 6 inches to $3 \mathrm{ft}$. high; leaves glaucous, an inch broad, or less; bracts mostly green; perianth 3 to 7 lines long, gland irregular and notched on its upper margin. Flowers perfect.

2. Z. venenosus, Wat. Stem slender, 6 inches to $2 \mathrm{ft}$. high; leaves rarely over 2 or 3 lines broad, scabrous; racemo simple, rarely compound, short, with narrow scarious bracts; perianth-segments 2 or 3 lines long. Flowers polygamous.

\section{ZRROPHYLIUM, Michx.}

Flowers white, in a sub-pyramidal many-flowered raceme. Styles reflexed or recoiled, stigmatic down the inner side. Cauline leaves numerous, setaceous.

1. X. tenax, Nutt. Stem 2 to $5 \mathrm{ft}$. liigh; leaves about 2 lines broad, often 2 or 3 ft. long; raceme becoming a foot or more long; perianth-segments oblong, 4 or 5 lines long, scarcely equaling the stamens.

LEUCOCRINUM MONTANUM, Nutt., is an acaulescent plant which produces 4 to 8 fragrant white flowers on short pedicels arising from a subterranean stem; the slender tube of the suver-form perias $t$, au inch or two loug.-Sandy valleys.

Order ARACEAs is represer.ted by SYMI LOC.ARPUS KAMTSCHATICCS Bong. (Skunk Cabbagn) a Jnarsh plant with large erect leaves, the llesing spidix becoming aid oblong-ovoid fruit two or threo inches in length. 


\section{ADDENDA.}

[To PAGE 60.]

Ginothera albicaulis, Nutt. Stems white, erect, $\frac{1}{2}$ to $4 \mathrm{ft}$. high; leaves linear to oblong-lanceolate, entire or repand-denticulate or sinuate-pinnatifid toward the base, 1 to 3 inches long; flowers axillary, white becoming pinkish, 1 to 2 inches in diameter; calyx tube an inch long or less; capsule an inch or two long.-Sand hills near Antioch.

\section{[To Pagr 62.]}

Mentzelia Lindleyi, Torr. \& Gr. Slender, 1 to $3 \mathrm{ft}$. high, branched; leaves ovate to narrowly lanceolate, 2 or 3 inches long, pectinately pinnatifid, or coarsely sinuatetoothed; flowers axillary and terminal; calyx lobes 5 to 9 lines long, lanceolate; petals obovate, abruptly acuminate, an inch long.-Corral Hollow, Mt. Hamilton.

\section{[To PAge 82.]}

Phacelia Douglasii, Torr. Pubescent and hirsute with mostly spreading hairs; leaves clongated-oblong or linear, pinnatifid, or pinnately parted into pairs of lobes, the terminal lobo hardly longer than the others; flowers loosely racemose, long-pediccled; calyx lobes spatulate. Low spreading stems with blue flowers rescmbling Nemoplita insignis:-Autioch, $A$. A. Bailey.

\section{[To PAGE 86.]}

Convolvulus arvensis, L. (Bindweed.) Stems procumbent and twining from deep rootstocks; leaves hastate to sagittate, $\frac{1}{2}$ to $1 \frac{1}{3}$ inches long; peduncles mostly 1-flowered, with a pair of minute bracts near the center; corolla a half to nearly an inch long, white, tinged with brownish red. $-\mathrm{A}$ troublesome weed now abundant in San Jose, Stockton, Oakland, etc. The lowers appear late in the dry season.

\section{[To PAGE SS.]}

Solanum Carolinense, L. (Horso Nettle.) Stems prickly; leaves ovate-oblong, sinuate-toothed, rough with stellate hairs, yellow prickles along the midrib, and ou the calyx; flowers pale blue or white, large; berries globular, orange-yellow.-Introduced at Vallejo, C. B. Towle.

\section{[To PAGE 01.]}

Tonella Collinsioides, Nutt. A slender plant distinguished from Collinsia by the leaves, some of them being 3-parted. Flowers minute, the tube slightly gibbous; stamens free from the lower lobe of the limb; capsule considerably exceeding the calyx. -Marin Co., Mrs Oakley.

\section{[To Page 01.]}

Pentstemon centranthifolius, Benth. Glaucous, strict and virgate, leafy 1 to $3 \mathrm{ft}$. high; leaves thick, ovatc-lanceolate, sessile; corolla deep and bright red, tubular, an inch or more long, the lobes nearly equal, very short; sterile filament naked. A showy species well worth cultivating for its deep vermilion flowers.-Very abundant on the sand-hills near Antioch. A. A. Bailey. 
[To Page 26.]

Viola glabella, Nutt. Stems 5 to 12 inches high, from a creeping root-stock, erect, leafy above, with a few bracts below; leaves corlate to reniform, acute, serrate or crenate; flowers yellow, veined with purple.-Redwoods.

[To PAGE 31.]

Sida hederacea, Torr. .Stems decumbent; leaves reniform, one-sided, irregularly crenate or dentate; flowers solitary or clustered in the axils, half an inch long, yellowish; calyx with one or two slender bractlets.

[To Page 105.]

Polygonum Paronychia, Cham. \& Schlecht. Stems woody, prostrate, leafy; leaves linear, revolute, the miùrib channeled, and each side ciliolate; the pinkish flowers in dense spikes.-Common near the coast.

[To PAGe 108.]

Sagittaria variabilis, Engelm (?). Flowers in whorls of three on an angled scape, one to several feet high, the upper flowers on longer pedicels and steril; calyx green; netals broad, 3 or 4 lines long, white; stamens many; ovaries forming a head of beaked achenia.-A marsh herb, with obtuse, sagittate leaves, or some (without a true blade) linear.

[To Page 109.]

Calypso borealis, Salisb. Bulb globular, solid, bearing a l-flowered scape, 5 or 6 inches in height, and a solitary ovate leaf; sepals and petals linear, pinkish, the lip slipper-shaped, 2-pointed underneath the apex, an inch long, variegated purple and yellow. Moist woods, Duncan's Mill, Russian River. Miss Wood.

[To Page 111.]

Erythronium grandiflorum, Pursh. Var. (?) Scape arising from an oblong corm, which bears a pair of broad leaves; flowers lily-like, racemose or solitary, yellowish, an inch or two long.-Healdsburg, R. II. Thomson. Cloverdale.

Ð. Hartwegi, Wat., has usually mottled leaves, the flowers solitary, or two or three in a sessile umbel. - Yuba Co., E. K. IIill.

ஐ. purpurassens, Wat., may be known by its large bulb, undulate leaves and purple tinged flowers.-Sierra Nevada.

\section{[To PAGE 18.]}

Ranunculus Bloomeri, Wat. Very smooth; hollow stems a foot high; leaves 3foliolate or entire, leaflets entire or nearly so; petals 5, mostly cuneate-oblong, emarginate, veiny; carpels straight-beaked.-Wet ground about San Francisco Bay. Vallejo, C. B. Towle. West Berkley; Baden; San Rafael, etc.

[To Page 80.]

Polemonium carneum, Gr. Branches 3-5-flowered; corolla salmon-color or flesh. color somctimes an iuch and a half across; stamens and style not longer than the corolla. 


\section{GLOSSARY.}

ABortion, the imperfect formation or absence of a part.

AsRopt, ending suddenly.

ACAOLESCENT, apparently stemless.

ACCUMBENT, the radicle lying against the edges of the cotyledons.

Acerose, needle-shaped, like pine leaves. Acumrate, ending in a tapering point. Accte, merely sharp-pointed.

Adnate, growing fast to. When the an-

ther seems to be attached by its whole

length to the filament.

AGGREGATE, crowded into a cluster.

Akene, a l-seeded seed-like fruit.

AlBUMEN, nourishment in the seed not

forming part of the embryo.

ANDrous, refers to stamens.

Anterior, on the side of the flower next

the bract.

APETAlous, without petals.

APPRESSED, lying flat, or close together.

Ascending, rising obliquely.

AtTendate, tapering gradually.

AURICUlate, ear-like lobes at the base.

Aws, an appendage like the beard of barley.

AxIL, the angle between leaf and stem.

BrFID, 2-cleft to about the middle. Bruablate, 2-lipped.

BLADE, the broad portion of a leaf
Bract, the leaf which subtends the flower. BRACTLET, a bract on a pedicel.

Cadocors, falling off at the time of expansion.

Campandlate, bell-shaped.

Canescent, whitened with fine close pubescence.

Capillary, like a hair.

Capitate, having a head, or collected into a head.

CAPSUle, any compound dehiscent fruit.

CARPEL, a simple pistil, or element of a compound one.

Caudate, tailed.

Caulescent, having an obvious stem.

CaULINE, relating to a stem.

Cilisate, fringed with hairs.

Clavate, club-shaped.

CuAw, the narrowed base of a petal.

CLEFT, cut to about the middle.

Conesion, the union of like organs.

CONFLUENT, running together, or blending.

Conglomerate, thickly clustered.

Connate, united from the first.

Connective, the part of an anther con. necting the cells.

ConNIVENT, coming together or meeting.

Convolute, rolled up.

Cordate. heart-shaped with the point up. 
Corrms, a flat-topped flower cluster, the pedicels unequal.

Costate, ribbed.

Cotruledons, the leaves of the embryo.

Creeping, running on the ground and rooting.

Crenate, the margin scolloped.

Cuneate, wedge-shaped.

Cuspidate, tipped with a rigid point.

Cyus, a flower cluster in which the oldest

flowers are in the center.

Decrdoous, falling off before withering; or,

if leaves, before winter.

Dechined, turned to one side.

Decumient, reclining on the ground, the end rising.

Deflexed, bent downwards.

Deniscent Fruits, etc., open by

Demiscence, splitting as pods do.

Dentate, toothed, the teeth pointing directly away from the margin.

DEPREsSED, flattened from above.

Diadelpiods, stamens united by the filaments in two sets.

Dichoromous, forking into two branches.

Dicotyledexous, having two seed leaves.

Diffese, widely and loosely spreading.

Digitate, compound with the parts arising at one point.

Drcecrods, with stamens and pistils in separate blossoms on different individuals.

Dissected, cut into pieces, or nearly so.

Distinct, when parts of the same name do not cohere.

Divaricate, separating widely.

Divergent, the summits inclined from each other.

Drupe, a stone fruit.(like a cherry).
Eurrryo, the rudimentary plant in a seed. ENTrRe, the margin whole and even, not lobed or toothed.

EpIgyrots, growing on the ovary.

Erose, irregularly notched as if gnawed. ExsERTED, protruding beyond other organs. Exstipulate, without stipules.

ExTropse, turned outward.

Fascicle, a close cyme, a bundle of leaves. Fertile Flower, one having pistils.

Filament, the stalk of an anther.

Filiform, like a thread.

Foliaceous, like a leaf.

Foliolate, consisting of leaflets (5-folio-

late means with five leaflets).

Follicle, a simple pod opening down one side.

Froit, the seed and all that belong to it.

Gladcots, covered with a whitish bloom which rubs off, as the surface of a cabbage leaf, or a plum.

Glomerate, clustered into a ball.

Glomerdere, a capitate cyme.

ILASTate, with a spreading lobe at the base on each side.

IIrRsute, clothed with coarse hairs. Hispid, beset with bristly hairs.

IOARY, grayish white from a white pubescence.

Hrpogrnots, growing under the pistil, free from the calyx and corolla.

INCUMBENT, when the radicle lies against the back of one of the cotyledons.

INFERIOR, underneath or anterior. INNATE, borne on the apex or end. INTRORSE, turned inward. 
IvvoLocre, a set of bracts surrounding a Hower cluster.

Ixvolute, rolled inward.

IRREGULAR, unequal in size or shape.

LACINIATE, cut into narrow incisions.

LAmiva, blade of a leaf or petal.

LATERAL, pertaining to the side.

LEGUME, fruit like a pea-pod.

LrMe, the exposed part of a corolla, calyx, etc., or the blade of a petal, etc.

LINE, the twelfth of an inch.

Linrar, narrow and much longer than wide, the margins parallel.

Lose, any division or projecting part.

MERous, the parts of a flower (5-merons, the parts in fives).

MUCronate, abruptly tipped with $\cdot a$ short point.

Nerves, parallel and simple veins.

Nodprsa, the apex or top pointing downward.

$\mathrm{OB}-$, prefixed means reverse of; as, ob-cordate, inverted heart-shaped, i. e., the stem attached to the apex.

Oblique, one-sided.

Oblong, long-elliptical.

Ochroleucous, pale dull yellow.

Oval, broadly elliptical.

Ovary, that portion of the pistil which becomes the seed vessel.

Ovate, like the longitudinal section of an egg.

Ovow, egg-shaped.

Palmate, lobed so that the lobes point away from the end of the petiole, as in an ivy or a maple leat.
PANICLE, a raceme branching irregularly.

Parted, cut almost through.

Pectinate, like the teeth of a comb.

Pedicel, the stalk of a single blossom in a cluster.

PEDUNCLe, the stalk of a cluster or of a solitary flower.

Perfoliate, when the stem seems to pass through the leaf.

Perforate, with holes or transparent dots.

Perigrnous, borne on the calyx.

Persistent, remaining until the fruit has grown.

Petrote, the leaf stem.

Petiolule, the stem of a leaflet.

PILOSE, with distinct straight hairs.

Pivnate, a compound leaf with the leaflets

along the side of a common petiole.

Pinnately cleft, LoBed, etc., with the

lobes along the sides of a long leaf.

Placenta, the part of the ovary which bears the seeds.

PoD, a dry dehiscent fruit.

PoMe, a fruit like a pear or apple.

Posterior, next the stem.

Procumbent, lying along the ground.

Prostrate, lying flat like a melon-vine.

Punescent, with soft or downy hairs.

Punctate, dotted as if by holes.

Punaent, rigid sharp-pointed.

RACEME, elongated flower bunches, with the oldest flowers below and on pedicels.

RADICAL, coming from the root (apparently). RADICLE, the stem of an embryo.

RENIFORM, kidney-shaped.

REPAND, the margin slightly wary.

Retrorse, directed backward.

RETUSE, slightly notched at a rounded apex. 
Revolute, rolled backward.

RAcHIs, the main stem in a spike, etc.

Roots'ock, an underground stem.

Rotate, wheel-shaped.

RUNCINATE, teeth pointing backward.

Sagittate, like an arrow-head.

SALVER-SIIAPED, tubular, the border spreading at right angles to the tube.

SCAPE, a flower-stalk rising from the ground - or near it.

SConproId, coiled round like a scorpion.

SEcund, all turned to one side.

Serrate, with tecth like a saw.

Setaceous, like a bristle.

Spatulate, like a druggist's spatula.

SPIKE, a long inflorescence of sessile flowers.

Stellate, star-shaped.

Strigm, the part of a pistil which receives the pollen.

Stipe, the stalk of an ovary.

STIPEL, the stipule of a leaflet.

Stipellate, having stipels.

Strpitate, having a stipe.
Stipule, appendage on each side at the base of a leaf.

STRICT, very straight or close or upright. Strigose, clothed with close-pressed stout sharp hairs or scale-like bristles. Strle, the slender part of a pistil. Subulate, tapering to a sharp rigid point. Suffrotescent, or suffruticose, shrubby at the base.

Terete, cylindrical, long and round.

Terminal, at the end or summit.

Tirysse, a thick panicle (Lilac blossoms).

Tomentose, clothed with a close and matted down.

Torulose, swollen at intervals.

Truncate, as if cut off at the end.

UMEEL, umbrella-like inflorescence.

Verticillate, whorled, forming a ring around the stem.

Villous, with long soft hairs.

VISCID, sticky.

ADDITIONAL WORDS.

Adventitious, out of the usual place; as roots on stems.

Cacdex, an upright rootstock.

Ccsp, a spear-like point.

Deltord, triangular.

Flaccid, soft, weak, drooping.

Fusifori, spindle-shaped.

GLabrous, smooth.

IrvoldCRATE, provided with an involucre.

Loculicidal, splitting down the middle of the back of a cell.

Lunate, crescent-shaped.

Mucronelate, tipped with a minute point.
Papilionaceous, like the corolla of a pea. Perianth, calyx and corolla together.

Reticulated, netted-veined.

Rugose, wrinkled, rough with wrinkles.

SacCate, with sacks or pouches.

Scabrots, rough or harsh.

Scariods, thin, dry, membranous.

SEPTICIDAL, splitting between the cells.

Spadix, a fleshy spike of flowers.

SPATHe, a bract which inwraps flowers.

Succulent, fleshy, juicy.

Staminodi, Sterile stamens or bodies like stamens.

Turbinate, top-shaped, an inverted cone. 


\section{GLOSSARY \\ or \\ GENERIC AND SPECIFIC NAMES.}

All the generic and specific names found in this work arc here defined except a few of obscure or unknown meaning and some which have undoubtedly been overlookerl. Commemorative names are followed by the names-when known to me-of those thus honored. Specific names are given sometimes in one gender, sometimes in another. The learner must know that, as a rule, if a specific name ends in us, $a$, or $u m$, it may end in either of the other two to correspond with the gender of the generic name; as, Convolvulus Californicus (Masculine), Polygala Californica (Feminine), Galium Californicum (Neuter). Or, the specific name may end in is or $e$, the former agreeing with masculine and feminine generic names, the latter with neuter names. The meaning of each name, where possible, is given in a form suitable for a common or English name of the plant.

Acilllezerolia, Yarrow-leaved.

Aconrrom, the ancient name.

Adenostoma, glandular stoma (breathing pores).

Afrinis, near, or related to.

Ajugordes, Ajuga-like; i. e., like Bugle, a

labiato plant.

Albens, white.

Albescens, becoming white.

Alricaulis, white-stemmed.

Alciemilla, the Arabic name.

Alismacrolius, Alisma-leaved, $i$. e., leaves

like those of Water Plantain.

Alurom, the Latin name of Garlic.

Alnifolia, Alder-leaved.

Amelanchier, the French name.

Anericana, American.

$\Lambda$ Mana, charming.

AMORPIA, without form (flower wanting

four petals).
Amplectans, twining or embracing.

AMplexicatlis, stem-encircled, i. e., by embracing leaves.

Amsinckia, William Amsinck, of Ham. burg.

ANAGaliIs, from a Greek word meaning to laugh.

Anagallomes, Anagallis-like; like Pimpernel.

Andersoni, Dr. C. L. Anderson, a California botanist.

Andrewsiana, Dr. Andrews, a pioneer botanist.

ANDrewsIr, Dr. Andrews, a pioneer botanist.

Avdromedia, in honor of the goddess of that name.

Anemone, from Greek for wind.

Avgustifolia, narrow-leaved.

Avseriva, from the Latin for goose. 
Aparine, the Greek name. Apocynum, dog-bane; dog-poison. Aqdatalis, aquatie; water. Aqurfoliom, Holly-leaved. AQUILEGIA, from Latin for eagle (the petals like eagles' claws). Arabis, from Arabia. Arenaria, sand, belonging in sand. Anboreds, tree-like. Ansutifolia, Arbutus-leaved. Arbutus, the ancient name. Arctostapiryos, Bearberry. Arimfolia, Aria-leaved. Armeria, the Monkish Latin for the Pink. Aromatica, aromatic.

Arvensis, field (growing in cultivated fields).

Asclepras, Esculapius, God of Medicine. Asper, rough.

AsPERUM, rongh.

Assurgentrflora, flowers bending upward.

Atrenuatus, slender.

Attenorfoliurs slender-leaved.

Audientia, M. Audibert, a Frenchman. Aurea, golden.

Aunrs, little-eared (referring to the leaves).

Azureus, blue.

Baritgerum, learded.

Dantsiafolia, Bartsia-leaved.

Briseris, the Arabic name for the Barberry.

Brcolor, two-colored.

Brensrs, biennial (i. e., flowering the second year and then dyin ).

Bifidum, bifid, divided.

Biflora, two-flowered.

Bifolidm, two-leaved.
Bigelovir, Dr. J. M. Digelow, a pioncer botanist.

BrLoba, two-lobed.

Bisceptrom, two-stemmed, i. e., two scapes.

Bistorta, twice-twisted.

Blepharophylla, eyelash-leaved.

Bloomeria, H. G. Bloomer, a pioneer botanist.

Bolanderr, H. N. Bolander, a well-known botanist of this coast.

Borealis, northern.

Boschniakra, Boschniaki, a Russian.

Boyminia, Dr. Boykin, of Georgia.

Brachycarpa, short-pod.

Bracteata, bracted.

Bracteosa, bracted.

Brassica, old name for cabbage.

Breviflora, short-flowered.

Brevifolium, short-leaved.

Breweri, Wm. H. Brewer, Botanist of the California Geological Survey.

Bronella, from German name of a throat disease which this plant was supposed to cure.

Bullata, jeweled; blistered.

Bursa-pastoris, shepherd's purse.

Chardleus, deep blue.

Casspitosa, tufted.

Calitornica, California.

Calochortus, beantiful grass.

Calycanthus, cup-flower.

Calycina, eup-like.

Campanula, bell.

Campestris, field (uncultivated).

Caradensis, Canadian.

Canescens, white-haired; hoary.

Canina, dog.

Canvabruum, hemp-like.

Capitata, capitate (bearing a head of (lowers). 
Capsella, little-pod.

Cardamine, heart-cure.

Cardinalis, cardinal; chief.

Carduacea, thistle-like.

Carolinense, Carolina.

Caroliniandu, Carolina.

Castilleia, Castillejo, a Spanish botanist.

Castilleiordes, Castilleia-like.

Ceanothos, old name.

Centranthifolius, Centranthus-leaved.

Cerasiformis, cherry-like.

Cerastium, from Greek for a horn (refer-

ring to the horn-shaped pods).

Cercocarpus, tailed-fruit.

Chammissonis, A. von Chamisso, a poet and botanist who visited this coast with Eschscholtz early in this century.

Cheirantuifolia, wallflower-leaved.

Cinemantiros, Arabic name.

Curlessis, Chili.

Chimaphila, winter-lover.

Chlorogalum, greenish milk.

Cirrysanthemifolia, Crysanthemum-

leaved.

Chrysantha, golden-flowered.

Ciliate, hair-fringed.

CirCAA, Circe, the enchantress.

Circinata, coiled; crosier-like.

Clarkia, General Wm. Clarke, who crossed the continent in 1803-1806.

Clayrovia, Dr. John Clayton, an early botanist of Virginia.

Clematis, ancient name of a climbing plant.

Cuivtonia, Governor De Witt Clinton, of New York.

Collivsia, Zaccheus Collins, of Philadelphia.

Collixsromes, Collinsia-like.

Collomin, from Greek for glue, on account of the mucilaginous seeds.
Comosum, hair-tufted.

Concinnum, beautiful.

Congesta, bunched.

Cordifolius, heart-leaved.

Cordylanthus, club-flower. .

Corymbosus, corymbose (flowers in a corymb).

Cotulafolia, Cotula-leaved.

Crassifolia, thick-leaved.

Crenatus, crenate.

Cressa, Cretan woman.

Cretica, Cretan.

Crocea, yellow; saffron-colored.

Crotellaria, rattle-pod.

Cuneatus, wedge-shaped.

Curvipes, curved-pedicel.

Crnoglossum, hound's-tongue.

Cxpripedium, Venus's slipper.

Citisordes, like snail-clover.

Datcra, an altered Arabic name.

Decorum, comely; pretty.

Delpirinium, dolphin.

Desissa, lowly; humble.

Dendromecon, tree-poppy.

Densifloros, dense-flowering.

Densifolia, densely-leaved.

Dentata, dentate; notched.

Denticulata, denticulate; finely toothed.

Dicentra, twice-spurred; two spurs.

Dichотом⿰㇇⿰亅⿱丿丶丶, two-forked.

Discolor, variable (as to color or form).

DIvaRICATA, spreading.

Dodecatheon, twelve gods.

Dotglasir, David Douglas, a Scottish ex.

plorer of the Botany of this coast.

Dumosa, bushy.

ECIINOSPERMUM, hedgehog-secd.

Elegans, elegant; beautiful.

ElLisia, John Ellis, an English botanist.

EMaIGrinata, emarginate; notched. 
Eumenantire, persistent-flower.

Eprlobium, a violet on a pod.

Erianthes, woolly-flowered.

Eriodyctyon, a network of wool (on the leaves).

Eritrichium, woolly-hair.

Lrodium, from Greek for heron (the fruit like the bill of a heron).

Lrysimem, from a word meaning to blister. ERy'Hras, from a word meaning red. Lschscholtzia, J. F. Eschscholtz, a German botanist, who visited California early in this century.

Eubrodial, true Brodiæa.

Falcifolitu, falchion-leaved.

FArivosa, starchy.

Fasciculata, fascicled (referring to the leaves).

Fadcibardates, beard-throat.

Filifolia, thrcad-leaved.

Flammula, a little banner or flame.

Floribunda, many-flowered.

Foliolosa, leafy.

Formosa, beautifully formed.

Fragaria, fragrance.

Fraxinus, from a Latin word meaning easily split.

Fritillaria, from Latin for checker-board,

the petals of the first-named species being checkered.

Fucata, colored,

Fulvem, tawny; yellow.

Galdica, Gallic (French).

Gadltheria, Dr. Gaulthier, of Quebec.

Gentiana, Gentius, king of Illyria.

Gigantra, gigantic; huge.

Grlea, Philip Gil.

Grthorsis, resembling Gith (Corn-cockle). Glaprus, smooth.
Glabratus, smooth.

Glandolosus, glandular.

Glauces, bluish-gray, or with a bloom.

GLAUX, from Greek for sea-green.

Glutinosus, glutinous; sticky.

Glycyrrhiza, sweet-root.

Godetia, Dr. Godet.

Gomphocarpus, nail-pod.

Gracile, slender.

Gracilentus, slender.

Graciliflonus, slender-flowered.

Grandiflora, grand-flowered.

Greener, Rev. E. L. Greene, who has diligently explored the Botany of this State.

Grmpocarpus, naked-fruited; naked-pod.

Hastatus, spear-bearing.

Hebecarpes, blunt-pod (?)

Hederaceus, Ivy-like.

HELIotropium, from Greek for sun and turn.

Heteropiyludus, variously leaved.

Heuchera, J. II. Heucher, a German botanist.

IIExandra, six-stamened.

Ifinsutissimus, bristly, or very hairy.

IIISPIDUla, bristly; prickly.

HumiLis, low; small.

Hypericun, the Greek name.

Ilicrrotios, Holly-leaved.

Ivcavus, gray; hoary.

ICIsUM, incised; cut.

INCONSPICUUS, inconspicuous.

Ixsignis, remarkable; marked.

INTEGERRIMCS, most vigorous.

INTEGRIFOLIA, entire-leaved.

INTERMEDIUS, intermediate.

INTERTEXTUS, intertwined.

INvoldCRATUs, involucrate. 
IrIs, rainbow.

Ixıordes, Ixia-like.

JuxCEA, rush-like.

Jossiana, Bernard de Jussieu, founder of the Natural System.

Labiate, from labia, a lip.

Lacinatos, laçiniate.

LACTEA, milk-white.

LAVICAULIS, smooth-stemmed.

LACUNosum, pitted.

LANceolates, lanceolate.

LATIFouros, broad-leaved.

LATHYRUS, the Greek name of a similar plant.

LATIPES, broad-pediceled.

LAXOS, loose.

LEPIGONUM, scaly-joint.

LEPIDIUM, scale-pod.

LEPTophyLLUS, slender-leaved.

LEPIDOTOS, scaly (?)

LEPIDUS, charming.

LeptosipHoN, slender-tubed.

Lemmoni, J. G. Lemmon, a very successful

California botanist.

LEUCODERMIS, white-skinned.

LEUCOCEPIIALUS, white-headed.

LEUCOCRINUM, white-lily.

LEUCOPHYLLUS, white-leaved.

Lewisia, Capt. M. Lewis, who crossed the continent with Clarke in 1803-1S06.

LigUstictrolius, Lovage-leared.

LrLiaceus, lily-like.

Limnantmes, pond-flower.

LrMonrom, mud-plant (an old generic name.)

Limoselia, from limus, mud.

LrNARIA, from Linum, the botanical name of Flax.

LINEARIFOLIOM, narrow-leaved.
Liniflora, flax-flowered; the Latin name Linum.

LITHOSPERMOIDES, like Lithospermum.

LTTTORALIS, sea-beach.

Lobatus, lobed.

Loxgiflorus, long-flowered.

LoNGILoba, long lobed.

LoNGIPEs, long-pediceled.

LUTEOLUS, yellowish.

LUTEUS, yellow.

LUPINUS, wolf.

Lupulinus, hop-like.

LucIDUs, bright, transparent.

LYcopus, wolf-foot.

Lycorsoides, Lycopus-like.

LYTHiOM, from Greek for blood.

Macranthos, large-flowered.

MACROCERA, large-horned.

Macrocarpa, large-fruited.

Macrostachya, large-spilked.

Macrothecum, large-anthered.

Maculatus, spotted.

MaIANTHeMum, mountain nymph.

MAJOR, greater; larger.

Malva, from a word meaning soft.

Malvatrorus, Mallows-flowered.

Malvarolios, Mallows-leaved.

MARIPOSA, butterfly.

MARITIMUM, coast.

Meadia, Dr. Mead, of Illinois.

Meconorsis, Poppy-like.

Medicago, from Media, its native countiy. Medrus, middle.

MEgarkHIZA, big-root.

Melinotus, honey-flower.

Mentria, from the name of a Nymph fabled to have been changed to mint.

MenYantHes, month-flower.

Menziesir, Dr. Archibald Menzies, a companion of Vancouver. 
Mentzelia, Dr. C. Mentzel.

Mertensia, Prof. F. C. Mertens, of Bremen.

Mesemeryanthemum, midday-flower.

Micrantirus, small-flowered.

MicrocepinaLUM, small-headed.

Microcalipes, small-fruited.

Micromeria, small-part.

Mruolus, ape; mimic.

Aineatus, vermilion-colored.

Mrsmus, smallest.

Minor, smaller.

Modes'rus, modest.

Mollugo, the Latin name.

Montunus, mountain.

Monardella, little Monarda, a genus named for Nicholas Monardes, a writer on medicinal plants.

Moschatus, musky.

Munlenberif, Dr. H. Muhlenberg, an American botanist.

Moilla, Allium reversed.

Multicaulis, many-stemmed.

Muricates, rough, with hard joints.

Mvitifolius, myrtle-leaved.

Nanus, dwarf.

Nemerosa, wood; forest.

Nemopima, grove-lover.

Nicotiana, Joln Nicot, who introduced tobacco into Europe.

Niteds, beantiful; bright.

Nitidum, shining.

Nudicaule, naked-stemmed.

Nudes, naked.

Nutrallia, Thomas Nuttall, botanist and ornithologist.

Ostusifolia, blunt-leaved.

Ocellata, spotted with little eyes.

Occidentalis, western.
CErothers, wine-sucker (roots cause thirst).

Officinalis, medicinal.

Orbicularis, round.

Oregana, Oregon.

ORTHOcARPUS, erect-fruit.

Ovata, egg-shaped (leaves).

OXYCARPUM, sharp-fruited.

OXYCARYuM, sharp-nut.

Psonia, the ancient name.

Pacifica, Pacific.

Palustris, swamp; marsh.

Papillosus, warty.

Parviflorus, small-flowered.

Parvifolics, small-leaved.

Patagonica, Patagonian.

Paucisecta, few-lobed.

Pectocarya, comb-toothed nut.

Pedatus, foot-shaped.

Pedicularis, from pediculus, a louse.

Peltatua, shield; shield-shaped.

Pexdoliflora, hanging flower; droopingflower.

Penicillata, brush-like. (Stigma with a tuft of hairs).

Pentstemon, five stamens.

Perroliata, perfoliate (the stem growing through the leaf).

Pharnaceoldes, Ginseng-like.

Pinladelpiros, Philadelphus, a King of Egypt.

Picti, painted; colored.

Pilosissina, most-hairy.

Pinnata, pinnate; feather-like.

Pines, old Latin name of the pear tree.

Platystemon, flat-stamen.

Platystigma, flat-stigma.

Pluriflora, many-flowered.

Pogogyne, bearded-pistil. 
Polygala, much milk (said to increase secretion of milk).

Polysepaloar, many-sepaled

Pomeridianca, after-noon.

Prenanthoides, Prenanthus-like.

Prosartes, from Greek to hang.

Prostatra, prostrate.

Psoralia, scurf.

Prerospora, wing-seed.

Ptelea, Greek for elm.

Pulchella, beautiful.

Pumra, dwarf; little.

Puxgens, pungent; biting.

Purpurascens, growing purple; purplish.

Pxcxantiemum, dense-flowers.

Pychantha, dense-flowering.

QUERcifolia, oak-leaved

Quadrangularis, four-sided.

Racemosa, racemose; raceme-betring.

RAdicANS, rooting.

Ramosissnat, branching; full of branches.

Ranunculus, from Latin for frog (some

of the species aquatic).

Raphanus, quick-grower.

TARIFLorUm, seldom-flowering.

Recurva, recurved.

Redrviva, reviving.

IiHoMrordea, rhomboidal.

Rurs, red (the prevailing color of the plentiful fruit in the genus).

Ribes, the Arabic name.

Rrgidus, stiff; rigid.

Rivularis, river.

Rosaxzorfia, Nicholas Romanzoff, a Russian nobleman, who early in this century sent Kiotzebue (accompanied by Chamisso and Eschscholtz) to this coast.

Rosa, the ancient namo.
Roseus, rosy.

Rotundifolia, round-leaved.

RuBEscens, reddening; reddish.

Rusus, red (the coior of the fruit).

Rustica, country; rustic.

Salvia, from a Latin word meaning to save.

SambUcus, from the name of an ancient musical instrument, said to have been made of Elder.

SANGUINEA, bloody.

SARCODES, from the Greek for flesh. SARMENToSA, running (as strawberries).

Satrva, cultivated; tame.

SAXIFRAGA, rock-breaker.

Scoliopus, worm-peduncle.

ScropHularia, scrofula cure.

Scutellaria, from scutella, a dish (because of the calyx).

Serpylloides, Thyme-like.

Serratum, serrate; toothed

Sessile, sessile; stemless.

Sessilifolia, sessile-leaved.

Shallow, the Indian name.

Sidalcia.

SileNe, from a Grcek word meaning saliva.

SrMplex, simple.

Sitchengis, Sitka.

SoLDANELLA, the generic name of another plant.

SoREDiatus, covered with granules.

SPARSIFLORUS, sparse-flowered.

Spatholata, spatulate.

Speciosus, showy.

SPECTABILIS, notable; admirable.

Specularia, from speculum, a lookingglass.

SpIrex, old name of Meadow Sweet.

Stacirys, the ancient name.

Stacirordes, Stachys-like. 
Statice, the ancient name.

Strellaria, from stella, a star.

Stellata, starry; star-like.

Stipularis, stipulate.

Stiveri, C. H. Stivers

STrictum, upright.

Strigulosus, bristly.

Strobilacea, cone-like (a pine cone).

Strobilina, little cone.

Stropiolirion, twisted-lily.

Subpinnata, nearly-pinnate.

Sympioricarpus, eluster-fruit.

Srmplocarpus, united-fruit.

Taxacetifolius, Tansy-leaved.

TATULA, an old generic name (?).

Tellima, enagram of Mitella.

Tenax, tough.

Texella, tender; delicate.

Texer, soft. tender.

Tenuiloba, slender-lobed.

Tenuifolius, thin-leaved.

Tessellata, checkered (seeds).

Thysavocarpus, fringe-pod.

THYrsiflonts, thyrse-flowered.

Tiarella, a little mitre (the pod).

Tixctoria, useful as a dye.

Tonentosus, woolly; tomentose.

Trachyandra, rough anther.

Tridentatus, three-toothed; threepronged.

Trichantha, hair-flowered.

Trichophyllos, hair-leaved.

Tricolor, three-colored.

TRIFIDUM, three-parted.

Triflorus, three-flowered.

Trifoliata, three-leaved.

Trifolium, three-leaves.
Trillom, triple (leaves, petais, etc., in threes).

Truncata, truncate.

Tuberosa, tuber-bearing.

Umbellata, umbellate.

UMBELliferdm, umbel-bearing.

UndUlate, wavy.

UNIFlorts, one-flowering.

Unifoliata, one-leaved.

Ursinus, bear.

VACCINNIUM, the ancient name.

VAGANS, wandering; spreading.

Vancouveria, Capt. George Vancouver, who explored this coast in 1792-1794.

Venenosus, deadly-poisonous.

Venosus, veiny.

Venustus, beautiful.

Vestita, clothed; covered.

Vernicosa, varnished.

Veronica, for St. Veronica (?).

Verticillata, whorled.

Villosus, hairy.

VISCIDULA, sticky.

Virginiensis, Virginian.

VITIS, the ancient name.

Vulgaris, common.

Wrimplea, Gen. A. W. Whipple, who visited this coast in 1849, in command of a Government Survey Party.

Xerophyllum, dry-leaf.

Yucca, the Indian name.

Zauschneria, M. Zauschner, a Tohemian botanist.

ZyGaDenOS, yoked-glands. 


\section{INDEX OF GENERIC AND COMMON NAMES.}

* * The names of orders are in capitals. Figures following names in parentheses denote the numbers of the species to which the common names apply; e. g., Baby-Lyes is the common name of the third species of Nemophila.

\begin{tabular}{|c|c|c|}
\hline the & PAGE & \\
\hline bronia & Baby-Eyes (Nemophila, 3) ... 81 & Camassia.......... \\
\hline ... 54 & Barberry ....... & CAPRIFOLIACI 2 \\
\hline & d-tongue (Pen & Capsella. \\
\hline ite (Aconitum). & traw (Galium & nine \\
\hline a............ & zer & \\
\hline $\operatorname{lus} \ldots \ldots \ldots \ldots \ldots \ldots, \ldots$ & & PIIY \\
\hline milla $\ldots \ldots \ldots \ldots \ldots \ldots, \ldots$ & ... & \\
\hline ia (Érodium).... & . 121 & Cea \\
\hline (Erodium)....... 33 & & \\
\hline & Dicentra, 1) 23 & hus. \\
\hline EA $\ldots, \ldots . . .$. & .. & \\
\hline ….. & & Ce \\
\hline .......... 5 & & -5 \\
\hline ............. 54 & (7T) & $\mathrm{ab}$ \\
\hline (.............. & .. & \\
\hline$\ddot{E} \cdots \cdots \ldots \ldots, 8$ & & \\
\hline $\begin{array}{c}\mathrm{E} \\
\ldots \ldots \ldots \ldots \ldots\end{array}$ & & \\
\hline$\ldots \ldots \ldots \ldots \ldots \ldots{ }_{107}^{73}$ & .... & C. \\
\hline & & C. \\
\hline ...... & & \\
\hline & & \\
\hline AE...... & & \\
\hline - $\quad \ldots$. & & Cl \\
\hline ....... & & \\
\hline ...... & & 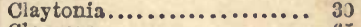 \\
\hline ... 120 & as) ... & \\
\hline . $\ldots$. & ... & 71 \\
\hline ...... & & (7) \\
\hline ........ & 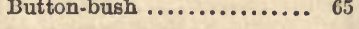 & \\
\hline los $\ldots \ldots$ & & \\
\hline CrEA & $\mathrm{y} \quad \mathrm{He}$ & C \\
\hline CEAS & Ho & \\
\hline ... & Ca] & \\
\hline 10 & Cal & Co \\
\hline & $\cdots$ & 121 \\
\hline E. & & \\
\hline & & \\
\hline & & \\
\hline 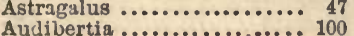 & & \\
\hline …......... & $\ddot{\mathrm{E} Z \mathrm{E}}$ & (nor \\
\hline
\end{tabular}




\begin{tabular}{|c|c|c|}
\hline & & 01 \\
\hline$\ldots 58$ & .. 76 & igonum \\
\hline ranesbill. & .. 104 & aco rinum \\
\hline ¿ASSULACEE............ & ithopsis. & Wrista. \\
\hline ream-Cups ................ & lasswort......................... & \\
\hline .... 87 & taux.............. & \\
\hline UCIFE & lycyrrhiza... & ium.... \\
\hline CURBITACEJE......... 63 & odetia.......... & \\
\hline 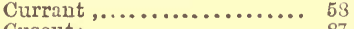 & rom hocarpus............ 74 & -Bell. \\
\hline uscut $_{3} \ldots \ldots \ldots \ldots \ldots \ldots \ldots \ldots, 87$ & $\cdots \ldots \ldots \ldots 58$ & sella. \\
\hline n............ & 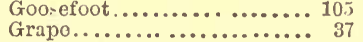 & $\cdots$ \\
\hline .............. 108 & reek Valerian............. 80 & \\
\hline …......... 83 & $\ldots 117$ & \\
\hline n............. & & \\
\hline n............ 21 & .. 109 & \\
\hline$\ldots \ldots \ldots 22$ & .. 21 & E. \\
\hline ........... 106 & (Stachys) ...... 101 & \\
\hline ........ 105 & m............ 25 & is) \\
\hline$\ldots \ldots \ldots$ & $\ldots \ldots \ldots \ldots \ldots .61$ & ... \\
\hline ....... 87 & [eliotropium. . & L \\
\hline a (Cornus, 1 )....... 63 & $\ldots \ldots \ldots \ldots 73$ & \\
\hline ia................. & 's Dill (Erodium) . .... 33 & \\
\hline & 54 & 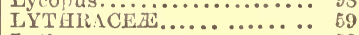 \\
\hline nospermum.. & 57 & Lyt \\
\hline 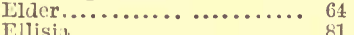 & quilegia) .... & \\
\hline the $\ldots \ldots \ldots \ldots \ldots \ldots,{ }_{82}^{81}$ & $\ldots \ldots \ldots \ldots \ldots{ }^{65}$ & is) $\ldots, \ldots$ \\
\hline 's Nightsiade (Cir- & Iop-Treo..................... 31 & \\
\hline & 121 & \\
\hline …..... 69 & $\ldots \ldots \ldots \ldots \ldots, 44$ & \\
\hline ......... 109 & gue (Cynoglos- & $\mathrm{E} \mathbb{E}$ \\
\hline .......... & ............ 86 & \\
\hline ... 83 & ... 69 & \\
\hline ... 105 & & \\
\hline j & CEZE. .... & n)... \\
\hline$\cdots \cdots$ & CEEA.. & ‥ \\
\hline • $\cdots \cdots \cdots \cdots$ & $\ldots \ldots 30$ & \\
\hline $\begin{array}{lll} & \cdots \cdots \cdots \cdots \cdots & 75 \\
21\end{array}$ & & $\cdots$ \\
\hline ................. & i). & \\
\hline 35 & $\ldots 110$ & $.62,1$ \\
\hline 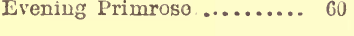 & $\ldots 110$ & \\
\hline ... & & \\
\hline & & \\
\hline ... & Jussiæa & 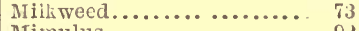 \\
\hline e) & & \\
\hline$\cdots$ & 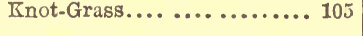 & $\cdots$ \\
\hline (............ 53 & & ....... \\
\hline .. 7.3 & & \\
\hline ... & 109 & I \\
\hline . 116 & nilla).. 54 & \\
\hline & $\ldots \ldots 109$ & ng - Glory (Convolvu- \\
\hline & - & eonj \\
\hline 1. & & \\
\hline ... 64 & 106 & $\mathrm{~N}$ \\
\hline & & \\
\hline 7 & & \\
\hline & 106 & \\
\hline & & \\
\hline & & \\
\hline & & \\
\hline
\end{tabular}




\begin{tabular}{|c|c|c|}
\hline resils & & Sistrinchinm \\
\hline osurus.... & 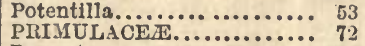 & $\begin{array}{l}\text { Sisyrinchium.. } \\
\text { Stull-cap...... }\end{array}$ \\
\hline egundo... & Prosartes...... & \\
\hline Sitis & Prince's-Pine (Chimaphila).. 71 & Skunk-tweed (G. squarrosa) \\
\hline ... 81 & runus.................. 50 & ed............. \\
\hline$\cdots$ & soralea. & Smilacin \\
\hline $\begin{array}{l}\text { ightsliade } \\
\text { inc-Bark. }\end{array}$ & $\ldots \ldots \ldots \ldots{ }^{34}$ & \\
\hline uphar... & Pterostegia. & Suow-Plant.. \\
\hline & m........ & \\
\hline 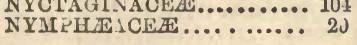 & .... & $\begin{array}{l}\text { CE.E. } \\
\text { C.... }\end{array}$ \\
\hline & & \\
\hline & & \\
\hline AGRACEA & aphan & S \\
\hline ... 112 & $\because 52$ & Spil \\
\hline .... 108 & attlc-weec & $\mathbf{S}_{\mathrm{i}}^{2} \mathrm{i}$ \\
\hline & HAMNACEZE....... & \\
\hline rberis, 2) .. & nus............. & $\left.\mathbf{S}_{p}\right)$ \\
\hline .... & 1........ & æ). \\
\hline $\begin{array}{ll}\ldots \ldots & 96 \\
\ldots \ldots & 94\end{array}$ & ihy & Squ \\
\hline .... 51 & (Plantago)..... & .. \\
\hline 1 & ffiliz............ & Sts \\
\hline & bit & St: \\
\hline & $\because 5 t$ & $\begin{array}{l}\text { St: } \\
\text { Ste }\end{array}$ \\
\hline ed-c & $\mathrm{ACE}$ & St \\
\hline ?... & - 10 & (in) \\
\hline '....... & 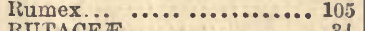 & $=$ \\
\hline$\cdots \cdots$ & ... & $n \ldots \ldots \ldots \ldots$ \\
\hline$\cdots$ & 100 & Tree \\
\hline$\cdots$ & 100 & rbutus)......... 11 \\
\hline$\ldots 91,121$ & & enct \\
\hline & & \\
\hline 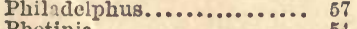 & & \\
\hline$\cdots$ & • & \\
\hline 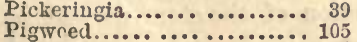 & & Sj \\
\hline$\ldots \ldots r^{10}$ & 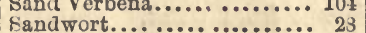 & \\
\hline 73 & 37 & Tel \\
\hline . 10 & & The \\
\hline & & \\
\hline & .. & $\mathbf{T l}$ \\
\hline & & \\
\hline 1 & $\because 119$ & n......... \\
\hline & ......... 119 & $\mathrm{Tl}$ \\
\hline & $E$ E & $\mathrm{Ti}$ \\
\hline & & \\
\hline & & \\
\hline & & \\
\hline & & \\
\hline & & ......... \\
\hline & 54 & ........ \\
\hline & 10.5 & 10 \\
\hline .... 105 & & 3.. \\
\hline & & \\
\hline & & $\mathrm{Tr}$ \\
\hline & & \\
\hline .. & mari & \\
\hline
\end{tabular}




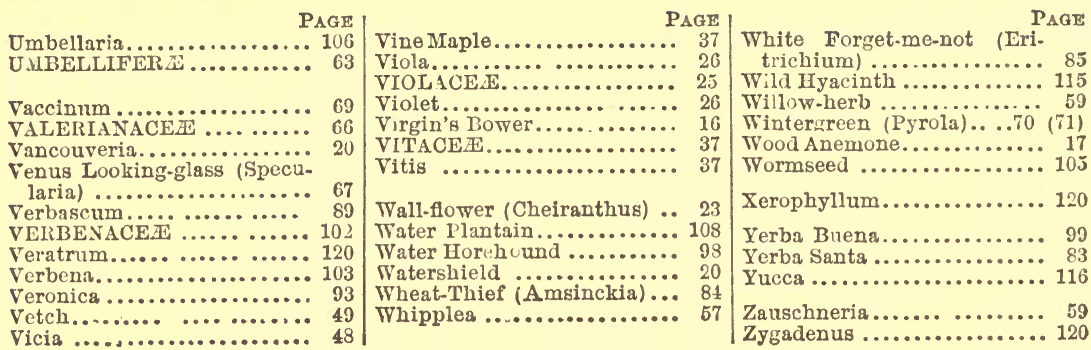

ADDITIONAI NAMES.

\begin{tabular}{|c|c|c|}
\hline PAGE & PAGE & PAGF \\
\hline Acacia ................ & Darlingtonia........ & Poplar. \\
\hline ... 106 & Digitalis.............. & $P$ \\
\hline .. 106 & glove............. & Рорру... \\
\hline .... 1 & nia.......... & g Asp.... \\
\hline ....2 2 & is $\ldots . .$. & . 106 \\
\hline 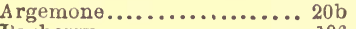 & .. 106 & - $20 \mathrm{~b}$ \\
\hline ... & ... $38 b$ & Salicaceə.... \\
\hline & $\ldots \ldots 106$ & St \\
\hline .. 1 & $\ldots \ldots \ldots \ldots \ldots$ & ........... \\
\hline ............. 20 & ............... & ularia............. 106 \\
\hline & r Tree................ & Walnut.... \\
\hline lote $\ldots \ldots \ldots \ldots \ldots \ldots 2$ & Piperacew ............... 105 & Willow................ 106 \\
\hline Chinquapin.............. 10 & Platanus.................. 106 & Yerba Mausa............. 106 \\
\hline
\end{tabular}

[Note to Page 76.]

"It has at length become evident that the unequal insertion of the stamens will nc longer serve to distinguish Collomia from Gilia. Transitions occur in the same species from very unequal to equal insertion, or nearer to equality than in some Gilias besicles those of the Navarretia section. The character of solitary ovules having also failed, nothing remains but to remand Nuttall's genus Collomic to the already large and much diversified genus Gilia. Collomia gracilis becomes Gilia gracilis, Hook.; C. gilioides is G. divaricata, Nutt.; C. heterophylla is G. Sessei, Don."-Dr. Asa Gray in Proceedings of the American Academy of Arts and Sciences, June, 1882.

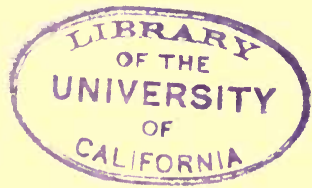



, 



\section{DAY USE \\ RETURN TO DESK FROM WHICH BORROWED \\ BIOLOGY LIBRARY}

TEL. NO. 642-2532

This book is due on the last date stamped below, or on the date to which renewed.

Renewed books are subject to immediate recall.

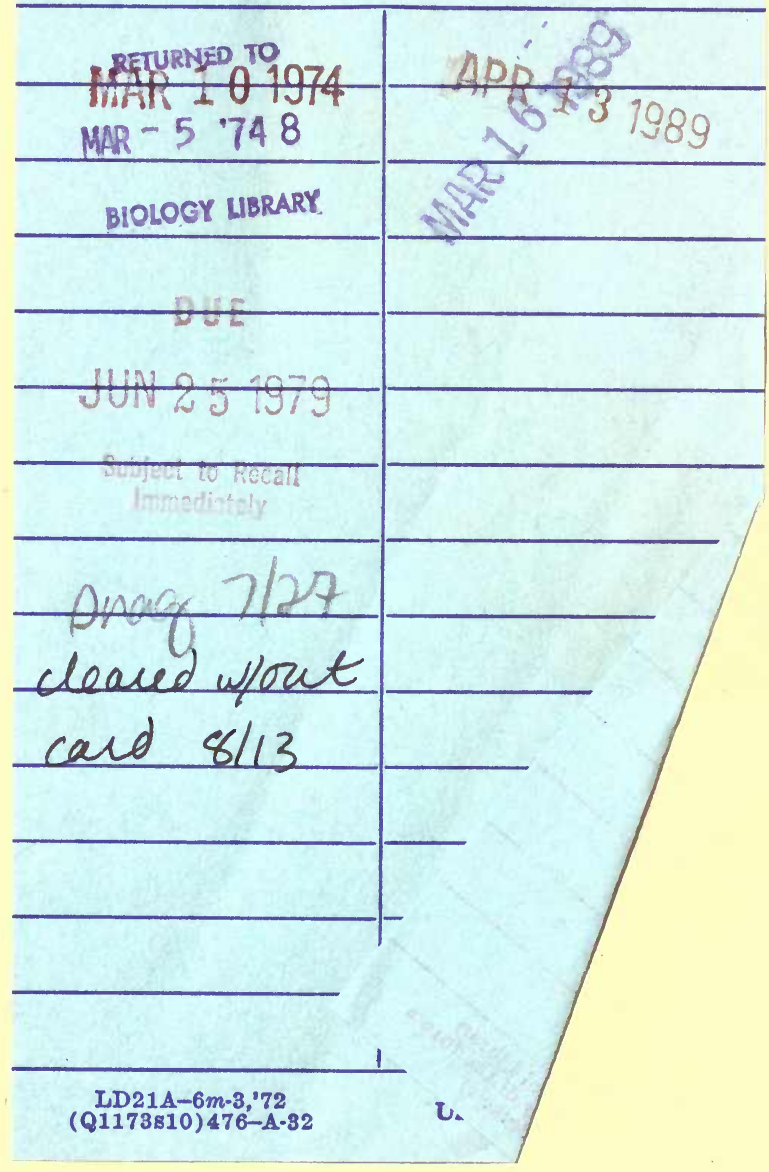




\section{U.C. BERKELEY LIBRARIES}

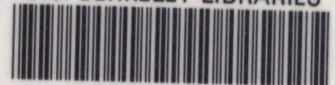

C026083204

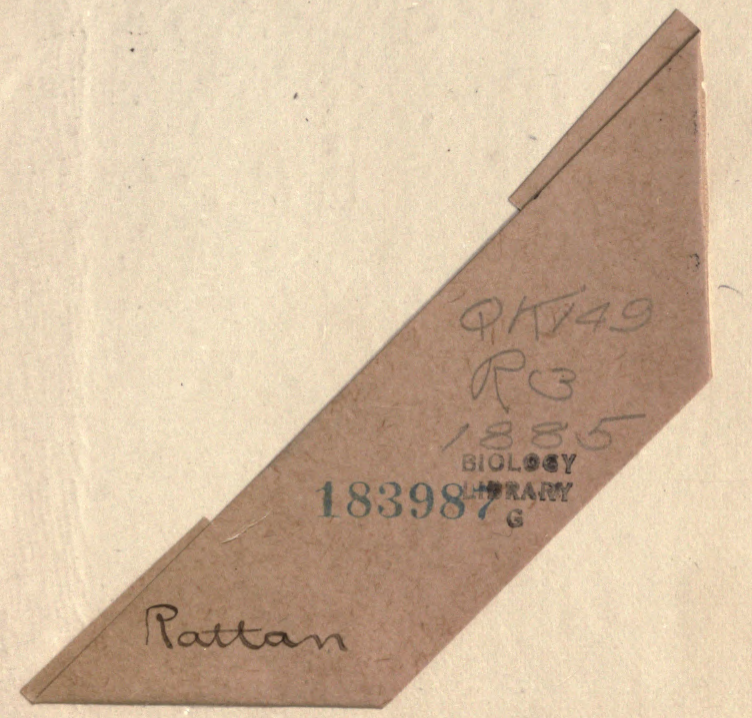




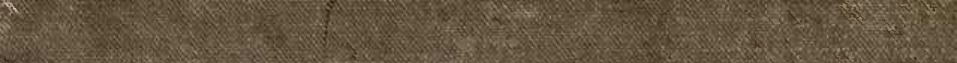

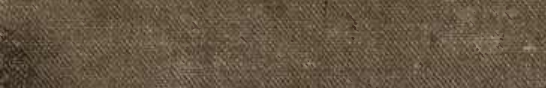

W.

Hating

3.t.

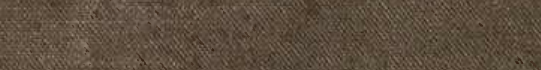

Sin

(5)

(n)

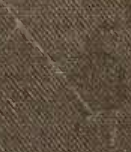

(n)

and

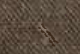

Non

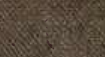

4hำ

1.5.

$\frac{1}{4}+\frac{1}{2}$

xis

4 急

Whe

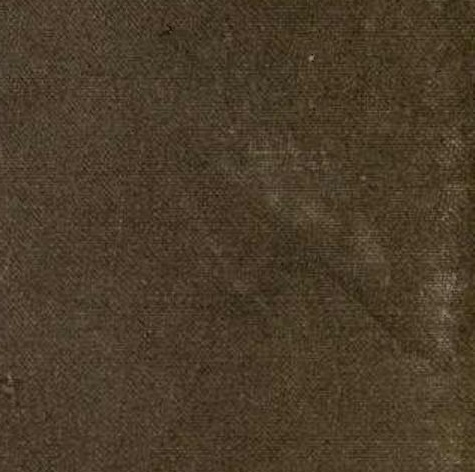

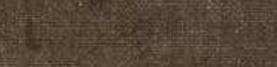

and

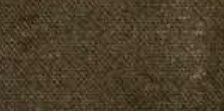

